Vinheta institucional:

uma análise sobre o processo de construção

da identidade audiovisual da Rede Globo de Televisão 


\author{
UNIVERSIDADE DE SÃO PAULO \\ ESCOLA DE COMUNICAÇÕES E ARTES \\ PROGRAMA DE PÓS-GRADUAÇÃO EM MEIOS E PROCESSOS AUDIOVISUAIS
}

Jaqueline Esther Schiavoni

\title{
Vinheta institucional: \\ uma análise sobre o processo de construção \\ da identidade audiovisual da Rede Globo de Televisão
}

Tese apresentada ao Programa de Pós-graduação em Meios e Processos Audiovisuais, na linha de Poéticas e Técnicas, da Escola de Comunicações e Artes da Universidade de São Paulo, como exigência para a obtenção de Título de Doutora em Meios e Processos Audiovisuais, sob a orientação do Prof. Dr. Eduardo Peñuela Cañizal e Prof. Dr. Mauro Wilton de Sousa. 


\section{Dedicatória}

\section{Moldura}

Para Eduardo Peñuela

Sempre se diz que as palavras expressam.

No meu caso, não.

Elas retêm.

São como molduras que aprisionam os sentidos.

Não dizem o que sinto ou o que penso, apenas o que os outros já sentiram ou pensaram. Estão instituídas e enrijecidas, embora por vezes se conformem em novas combinações. $\mathrm{Eu}$, no entanto, jamais me conformarei.

Não me prenderei numa forma.

Haveria de criar milhares de palavras e ainda assim não traduziriam as tonalidades do meu coração ou as nuanças do meu pensamento.

Os sentimentos estão aprisionados como imagens numa tela

e trabalho incessantemente para que alcancem o que está fora de campo

Insinuo com um olhar,

um gesto,

um movimento...

E se me contemplam enigmáticos

Posso ter a esperança

De que, enfim, fui compreendido.

(Barcelona, abril de 2013

- por ocasião de $O$ texto fílmico entre a moldura e o enquadramento,

in Revista Significação, v. 39, n. 38, 2012). 


\title{
Agradecimentos
}

\author{
À Fapesp, \\ pela bolsa de estudo.
}

Ao Mauro Wilton de Sousa, por ter sido um abrigo contra o vento. 


\title{
Vinheta institucional: uma análise sobre o processo de construção da identidade audiovisual da Rede Globo de Televisão
}

Resumo: Este trabalho se estrutura sobre a tese de que o sucesso da Rede Globo como empresa televisiva está intimamente relacionado com a criação - e exploração - de uma identidade audiovisual. Assim, a investigação avança no sentido de expor que identidade é essa e como ela se projeta por meio das vinhetas institucionais da emissora. Para isso, se utiliza do modelo Projeto/Manifestações proposto por Andrea Semprini, e o instrumental teórico da semiótica francesa.

Palavras-chave: Televisão, identidade, vinheta, Rede Globo, semiótica.

\begin{abstract}
This work is structured on the thesis that the success of Rede Globo as a television company is closely associated with the creation - and exploration - of a audiovisual identity. Thus, the research moves towards exposing what identity is that and how it is designed by the institutional vignettes. The theoretical reference used is the model Project/Manifestation proposed by Andrea Semprini and the instrumental of French semiotics.
\end{abstract}

Key-words: Television identity, vignette, Rede Globo, semiotcs. 


\section{Sumário}

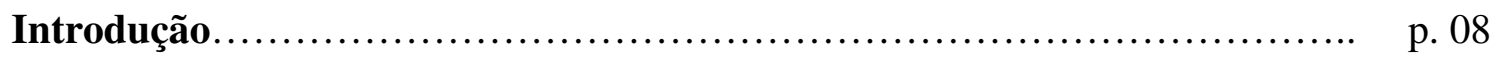

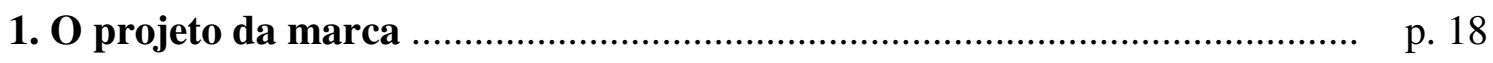

1.1 Construção e estabelecimento .............................................................. p. 19

1.2. Evolução ….......................................................................................... p. 29

1.2.1 A marca da Globo em diferentes tipos de materiais .......................... p. 32

1.2.2 Atualizaçõos e experimentações ...................................................... p. 35

2. Do projeto à comunicação da marca …................................................... p. 36

2.1 Recursos visuais: por uma imagem positiva e duradoura ......................... p. 37

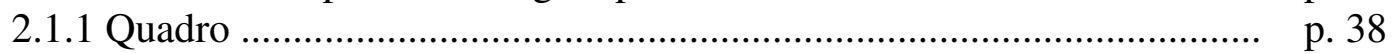

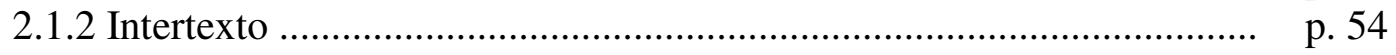

2.1.3 Metáfora ….......................................................................... p. 56

2.1.4 Metalinguagem .................................................................... p. 61

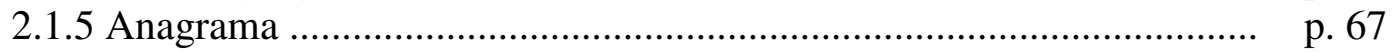

Considerações preliminares .................................................................... p. 76

2.2 Recursos sonoros: elementos de identidade ….......................................... p. 78

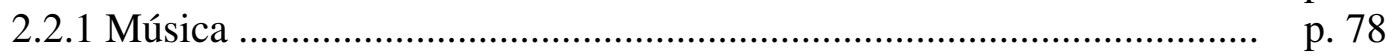

2.2.2 Jingles e spots ............................................................................ p. 79

2.2.2.1 Enunciação fundamental: mediação ........................................... p. 84

2.2.2.2 Promessa: interação ............................................................. p. 86

2.2.2.3 Especificação da promessa: âmbito global ............................... p. 88

2.2.2.4 Território: televisão ................................................................... p. 89

2.2.2.5 Valores: tecnologia e pluralidade ……....................................... p. 89

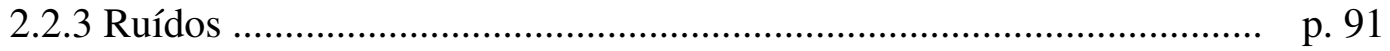

2.2.4 Relações audiovisuais ................................................................... p. 94

Considerações preliminares ......................................................................... p. 97

3. Da comunicação da marca ao produto...................................................... p. p 101

$3.1 \mathrm{O}$ contrato ................................................................................ p. 101

3.2 A competência .............................................................................. p. 107

3.3 A performance ….......................................................................... p. 108

3.4 A sanção ........................................................................................ p. 112

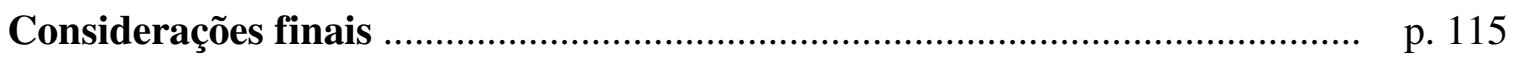

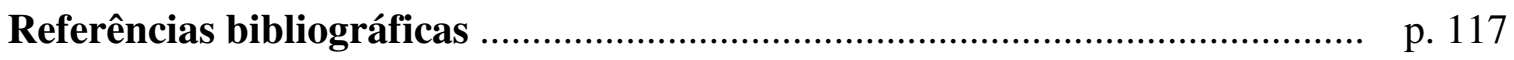

Apêndice I

Vinheta de TV: tipos, usos e funções ………............................................... p. 121

\section{Apêndice II}

Rede Globo: slogans e identidade …........................................................... p. 155 


\section{Lista de figuras}

Fig. 1: Logomarcas da Globo I ...................................................................... p. p 19

Fig. 2: Vinheta - O que é bom está na Globo I ............................................... p. 26

Fig. 3: Vinheta - Vem aí mais um campeão de audiência ................................... p. 26

Fig. 4: Vinheta - Tubos coloridos …................................................................. p. 27

Fig. 5: Vinheta - Abre alas .......................................................................... p. 27

Fig. 6: Vinheta - Interprogramas …................................................................ p. 27

Fig. 7: Vinheta - Cidade futurista ….......................................................... p. 28

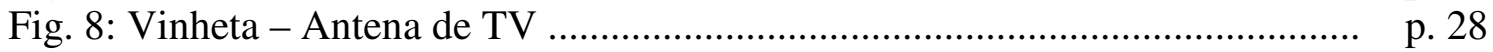

Fig. 9: Logomarcas da Globo II .................................................................... p. p. 29

Fig. 10: Vinheta - Bolhas de sabão .................................................................... p. 33

Fig. 11: Vinheta - Globo 2000, no coração do Brasil ............................................ p. p. 33

Fig. 12: Vinheta - A gente se vê por aqui ....................................................... p. 34

Fig. 13:Cena do filme Minority Report …........................................................ p. 39

Fig. 14: Vinheta - A gente se liga em você I .................................................. p. 40

Fig. 15: Vinheta - A Globo 90 é nota 100 ........................................................ p. 47

Fig. 16: Vinheta - Globo e você, tudo a ver ....................................................... p. 57

Fig. 17: Vinheta - $\mathrm{O}$ veículo de comunicação número 1 do país ........................... p. 61

Fig. 18: Vinheta - A gente se liga em você II ................................................. p. 68

Fig. 19: Vinheta - O que é bom está na Globo II ................................................ p. 102

Fig. 20: Vinheta - A Globo está em movimento …................................................ p. 104

Fig. 21: Vinhetas - TV Tupi ............................................................................ p. p. 126

Fig. 22: As grades do graytellop ….............................................................. p. 128

\section{Lista de quadros e tabelas}

Quadro 1: Slogans Rede Globo ……................................................................. p. 80

Quadro 2: Percurso gerativo do plano da expressão …….................................... p. 144

Quadro 3: A autorreferencialidade na televisão ………................................... p. 148

Quadro 4: Fazer missivo ................................................................................... p. p. 149

Tabela 1: Slogans e identidade …............................................................... p. 83

Tabela 2: Modalidades ................................................................................. p. 107

Tabela 3: Grade televisiva (Manhã) ……........................................................ p. 109

Tabela 4: Grade televisiva (Tarde) …............................................................... p. p. 110

Tabela 5: Grade televisiva (Noite) .................................................................. p. p. 111

Tabela 6: Distribuição dos gêneros na programação diária da Rede Globo ........... p. 111

Tabela 7: Os programas mais vistos da TV brasileira …........................................ p. 113 


\section{Introdução}

Há quase 50 anos, mais precisamente em 26 de abril de 1965, era inaugurada no canal 4, no Rio de Janeiro, a Rede Globo de Televisão. No decorrer das décadas, a emissora não apenas expandiu a produção e difusão de sua programação, que ganhou abrangência nacional, como também se tornou a mais influente rede de televisão do país. Evidentemente, não se tratam apenas de índices de audiência, mas, sobretudo, de um lugar de destaque no imaginário coletivo - e para a concorrência, inegavelmente, uma referência a ser considerada. Sendo assim, qual o segredo do sucesso?

Este trabalho se estrutura sobre a tese de que o êxito da Rede Globo como empresa televisiva está intimamente relacionado à criação - e exploração - de uma identidade audiovisual. A investigação avança, portanto, no sentido de expor que identidade é essa e por meio de que processos ela se projeta.

Para isso, tomarei como base o modelo Projeto/Manifestações, proposto pelo especialista em marca Andrea Semprini, e o instrumental da semiótica francesa, notadamente o percurso gerativo de sentido, com o qual dialoga o teórico italiano. Para ele, a marca é uma instância eminentemente semiótica e seu aparecimento no mercado deve ser encarado como um processo de enunciação no qual valores abstratos ganham concretude. Assim, Semprini articula projeto de marca e manifestações da marca tal como faz a própria semiótica em relação aos conceitos de enunciação e enunciado - e nos dois casos, por haver uma relação de pressuposição, somente se consegue depreender o sentido abstrado do primeiro pelas ocorrências concretas do segundo.

De acordo com Semprini, há muitas formas de manifestar o projeto de uma marca. Dentre elas: preço, posicionamento, distribuição, comunicação e o próprio produto. Embora todas as formas gozem do mesmo estatuto, nem todas gozam do mesmo peso. $\mathrm{O}$ que significa dizer que, conforme cada caso, alguns tipos de manifestações são mais importantes do que outras. No cenário atual, em se tratando dos enunciados que a televisão produz sobre si mesma, as vinhetas institucionais ocupam esse lugar privilegiado - por serem veiculadas no próprio meio que promovem; por conseguirem penetração social; por atraírem o telespectador com o uso de diferentes linguagens em sincrestismo etc. E é por esse motivo que constituem neste trabalho meu objeto de análise. 
Tais enunciados audiovisuais foram então tomados desde o surgimento do atual projeto de marca da emissora até o presente momento, pois creio que o caráter específico da marca se revela a partir de seu movimento no tempo e é a reunião das análises feitas sobre cada uma de suas manifestações em quase quarenta anos de história o que me permitirá reconhecer tal especificidade. Em outros termos, creio que cada manifestação contém boa parte da identidade global da marca e a visada diacronica é o que nos fará ter uma visão sobre o todo.

Dessa forma, como prevê o modelo de Semprini, cada uma dessas manifestações será considerada como um enunciado em si, no qual se podem aplicar os conceitos operacionais do percurso gerativo de sentido. Esse modelo desenvolvido por Greimas se estabelece sobre sucessivos níveis de análise - daí a noção de percurso -, constituídos por estruturas semio-narrativas e estruturas discursivas, admitindo-se que todo tipo de objeto significante pode ou mesmo deve ser definido segundo seu modo de produção. De maneira que a constituição do sentido não resulta de outra coisa que não o desenvolvimento lógico dessas estruturas conforme são citadas no próprio texto ou objeto que se analisa, e não fora dele - daí a noção de gerativo.

Designamos pela expressão percurso gerativo a economia geral de uma teoria semiótica (ou apenas linguística), vale dizer, a disposição de seus componentes uns com relação aos outros, e isso na perspectiva da geração, isto é, postulando que, podendo todo objeto semiótico ser definido segundo o modo de sua produção, os componentes que intervêm nesse processo se articulam uns com os outros de acordo com um 'percurso' que vai do mais simples ao mais complexo, do mais abstrato ao mais concreto (GREIMAS; COURTÉS, 1983, p. 206).

O percurso gerativo é, portanto, um modelo que parte de instâncias mais simples e abstratas e chega a outras mais complexas e concretas. As estruturas semio-narrativas, que constituem o nível mais abstrato, a instância a quo do percurso gerativo como define Greimas, têm por referência os conceitos de "língua", de Saussure e Benveniste, bem como o de "competência", desenvolvido por Chomsky e ampliado para as dimensões do discurso, e podem elas mesmas serem divididas em um nível mais profundo e outro mais superfícial, denominados de fundamental e narrativo. 
Assim, no nível fundamental, estão as "diferentes diferenças" que fundam a significação, cujas relações que mantêm entre si podem ser explicitadas em termos de contrariedade, ou contraditoriedade num quadrado semiótico - este, portanto, tido como a representação visual da articulação lógica de uma categoria qualquer, como explica JeanMarie Floch ao citar, a título de exemplo, a oposição "masculino" vs. "feminino":

\section{Masculino Feminino}<smiles>CC(C)(C)C</smiles>

não-femino não-masculino

Tomemos um exemplo: a oposição masculino/feminino. Esta relação pode ser considerada como um eixo semântico onde cada um dos dois termos pressupõe o outro: os dois termos estão em uma relação qualitativa, em contrariedade. A característica desta relação é que os dois termos podem estar presentes de modo concomintante. Mas esses dois termos da categoriam podem separadamente contratar uma relação privativa: cada um, marcado pela presença de um traço distintivo, estará em contradição com o termo que é definido pela ausência deste traço. Essa relação de contradição traduz uma visão estática: de um ponto de vista dinâmico, ela corresponde a uma operação de negação. A contradição é caracterizada pela impossibilidade de ver seus dois termos coexistir: feminino/não-masculino, masculino/não-feminino são duas contradições exemplares (2001, p. 19).

No nível narrativo, os sentidos articulados pelas oposições fundamentais passam a ser assumidos por um sujeito e constituídos como objetos-valor - a serem perseguidos ou evitados. É um nível, portanto, que articula situações e ações, isto significa, estados e transformações. A reflexão sobre como todos esses elementos se organizam tem origem nas análises que Vladimir Propp efetuou sobre contos maravilhosos russos e, a partir desse material, a semiótica pretendeu um modelo mais geral e abstrato, de tipo universal, capaz de servir de ponto de partida para a compreensão dos princípios de organização de todo e 
qualquer discurso narrativo, baseado em enunciados de fazer que regem enunciados de estado - pois considerou este o mínimo necessário para haver qualquer tipo de narrativa e a tal modelo denominou programa narrativo $(\mathrm{PN})$. Este pode ser representado sob as duas formas seguintes:

$$
\begin{aligned}
& \mathrm{PN}=\mathrm{F}\left[\mathrm{S}_{1} \rightarrow\left(\mathrm{S}_{2} \cap \mathrm{O}_{\mathrm{v}}\right)\right] \\
& \mathrm{PN}=\mathrm{F}\left[\mathrm{S}_{1} \rightarrow\left(\mathrm{S}_{2} \cup \mathrm{O}_{\mathrm{v}}\right)\right]
\end{aligned}
$$

Onde:

$\mathrm{F}=$ função

$\mathrm{S} 1=$ sujeito de fazer

$\mathrm{S} 2$ = sujeito de estado

$\mathrm{Ov}=$ objeto investido de valor

[ ] = enunciado de fazer

()$=$ enunciado de estado

$\rightarrow=$ função fazer (resultante da conversão da transformação)

$\vec{\cap} \cup=$ junção (conjunção ou disjunção) que indica o estado final, a consequência do fazer.

A partir dessa formulação pode-se trabalhar em termos de produção e de análise com a complexidade e hierarquia dos programas (simples ou complexos), a natureza das transformações (aquisição ou privação), o valor dos objetos postos em circulação (descritivo ou modal), e com as relações que se estabelecem entre os sujeitos envolvidos na ação (transitiva ou reflexiva). Visto que em todos esses casos a organização subjacente da narrativa gira em torno de uma performance por parte do sujeito e da competência prévia que ele precisa para tanto, pode-se chegar ao seguinte esquema narrativo:

\begin{tabular}{ccc} 
Contrato & Sanção \\
\hline & Competência & Performance
\end{tabular}

Em que:

1) O contrato se configura pelas condições mínimas que justificam a tomada de contato de um sujeito para com outro; envolve, portanto, os pressupostos que fundamentam o estabelecimento da estrutura da comunicação semiótica, visando estabelecer uma relação intersubjetiva que tem por efeito modificar o estatuto de cada um dos sujeitos envolvidos; 2) a competência diz respeito às preliminares modais - querer, poder, dever, saber - que tornam a ação possível; 3) a performance se configura o fazer mesmo do sujeito competente que permitirá a ele adquirir valores descritivos; e 4) a sanção, por fim, é o 
juízo epistêmico proferido pelo destinatário sobre a conformidade dos comportamentos e, mais precisamente, da coerência do programa narrativo em relação ao sistema axiológico proposto no contrato inicial (GREIMAS; COURTÉS, p. 84, 63, 328, 389).

Tal esquema narrativo deixa evidente que, se por um lado, a dimensão pragmática -

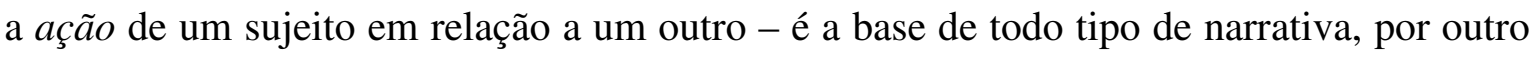
mostra que esse fazer é sempre regido por um contrato anterior e, portanto, por uma dimensão cognitiva. Isso acontece não apenas no âmbito do enunciado, mas, com efeito, se estende também para a esfera da enunciação. E, nos dois casos, a sanção positiva ou negativa quer do destinatário quer do enunciatário se dará pela conformidade ou nãoconformidade entre a performance do sujeito e o contrato que ele propõe.

Esta é, sem dúvida, uma noção muito cara para este trabalho, pois quando afirmo que o sucesso da Rede Globo como empresa televisiva está intimamente relacionado à criação e exploração de uma identidade audiovisual não estou fazendo outra coisa senão atrelar a sanção positiva do telespectador como enunciatário - levando-se em conta o sucesso da emissora em termos de audiência e reconhecimento - a um percurso de coerência entre a proposta contratual e a ação efetiva da emissora, quer dizer, entre o projeto de marca e as manifestações da marca - lembrando que, para além das vinhetas institucionais, a própria programação televisiva faz parte deste último conjunto. Isso justifica a estrutura que projetei para este trabalho: a explicitação do projeto da marca no primeiro capítulo, e análise das manifestações da marca no segundo e terceiro capítulos, a saber, as vinhetas institucionais e os conteúdos da grade televisiva, respectivamente como detalharei mais adiante.

Visto que o fazer persuasivo do enunciador buscará sempre a adesão do enunciatário, que por sua vez estará sempre condicionada ao fazer interpretativo dele - à medida que atribuiu à manifestação do enunciado (parcer/não-parecer) este ou aquele estatuto ao nível da imanência (ser/não-ser) - buscar-se-á no nível mais superficial do percurso gerativo, o nível discursivo, a realização de escolhas aspectuais (pessoa, espaço e tempo) e procedimentos de tematização e figurativização que direcionem o crivo de leitura do enunciatário conforme os valores estipulados no nível fundamental e as transformações do nível narrativo, eliminando as possíveis ambiguidades em prol de uma leitura uniforme.

Percebe-se, dessa maneira, que o percurso gerativo de sentido se estrutura sobre reiterações: os valores abstratos propostos no nível fundamental são atualizados no nível narrativo e ganham especificidade no nível discursivo. Visto que cada manifestação da 
marca é, na verdade, um enunciado em si, esse padrão se mantém também nelas. De modo que encontraremos no nível fundamental os valores abstratos fundadores da própria identidade da marca, suscetíveis de serem explorados pelo sujeito da enunciação; já no nível narrativo, a seleção e explicitação de tais valores, definindo, em parte, o tipo de discurso que será produzido; e, por fim, no nível discursivo - o mais sensível ao ambiente sociocultural, aos modos de vida e ao comportamento dos receptores - estarão dispostos os objetos, as formas, as cores, enfim, as figuras do mundo natural que enriquecerão e particularizarão o discurso.

Especificados os três níveis do modelo greimasiano, torna-se evidente a necessidade de coerência na passagem de uma etapa para outra ao se construir um enunciado. No modelo de Semprini, essa mesma coerência é o que revelará, numa dada manifestação, certo aspecto da identidade da marca. Porém, tais manifestações não devem ser tomadas de maneira isolada. Como afirma o teórico italiano, "só a repetição deste processo analítico aplicado a inúmeras manifestações da marca permitirá ter uma ideia mais aprofundada de seu projeto" (SEMPRINI, 2006, p.170) - daí minha decisão por trabalhar com as vinhetas ao longo de toda a trajetória da Rede Globo desde a criação do projeto atual, como apontei anteriormente.

Além de dialogar com o modelo de Andrea Semprini, o percurso gerativo de sentido é a referencia da qual partem desenvolvimentos recentes da semiótica - como o percurso gerativo do plano da expressão, de Jacques Fontanille e o fazer missivo, de Claude Zilberberg - que utilizo no Apêndice I que segue ao final deste trabalho ao analisar certos usos e funções da vinheta televisiva nos dias de hoje.

Tais proposiçoes teóricas buscam preencher certas lacunas do projeto greimasiano, como o fato de que, apesar de compreender o sistema semiótico como a articulação entre um plano de conteúdo e um plano da expressão, o percurso gerativo constitua apenas o que Louis Hjelmslev (1975) conceitua como forma do conteúdo. É nesse sentido que se apresentam os níveis de pertinência fontanillianos ao "eleger as instâncias da experiência e da existência semióticas, e relacionar a forma da expressão à substância da experiência e a forma do conteúdo à substância da existência, definindo um horizonte ôntico de significação" (PORTELA, 2008, p. 97-98) redefinindo, portanto, a natureza das semióticas-objeto. Segundo Fontanille, "tratar-se-ia não de inserir o objeto de análise em seu contexto, mas, ao contrário, de integrar o contexto ao objeto de análise, assumindo como consequencia o fato de que, semioticamente falando, o contexto não se situa 'nem 
antes, nem depois, mas no âmago da linguagem' (LANDOWSKI apud FONTANILLE, 2009, p. 16).

De maneira similar, Zilberberg parte das mesmas teorias de base utilizadas no desenvolvimento do percurso gerativo - como Saussure, Hjelmslev, Brøndal e, evidentemente, Greimas - para formalizar um novo modelo em que as oscilações tensivas seriam responsáveis por reger o discurso desde suas etapas mais profundas (TATIT apud RIBEIRO, 2010, p. 19-20). O próprio conceito de missividade, proposto por Zilberberg a partir da noção de antiprograma de L. Panier, evidencia essa característica. Quando ele levanta "a suposição de que todo momento da cadeia é um lugar de mobilização emocional e, eventualmente, de resolução de um contraste entre um programa e um antiprograma" (ZILBERBERG, 2006, p. 133) está claramente aludindo ao nível narrativo do percurso gerativo de sentido. Porém, vai além dele ao explicitar os valores de emissividade e remissividade em virtude dos quais alguma coisa acontece ou deixa de acontecer.

Justificada a escolha do objeto e apontada a teoria de base, falta ainda explicar a estrutura do trabalho e detalhar os principais conteúdos a serem abordados nos três capítulos que o conformam. Para isso, retomo mais uma vez o modelo proposto por Andrea Semprini e a contextualização que o autor faz da marca pós-moderna. Segundo ele, o mercado sofreu uma grande reviravolta nos anos 90, quando este passou a privilegiar valores imateriais, orientando-se, de fato, a partir deles. De modo que em nosso tempo "as dimensões simbólicas e semióticas tornam-se cruciais, elas fornecem o próprio combustível que alimenta o universo do consumo e sua impressionante aceleração" (2006, p. 152). Grosso modo, a nova lógica que se instaura deixa para trás o modelo do marketing mix, inteiramente construído a partir do produto, e instaura o chamado mix de marca, que se orienta a partir de valores imateriais, quer dizer, dimensões simbólicas.

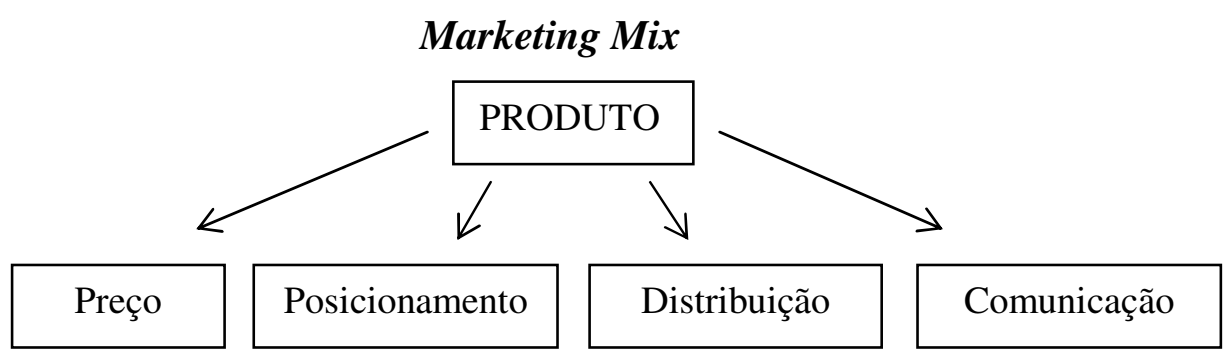


Mix de Marca

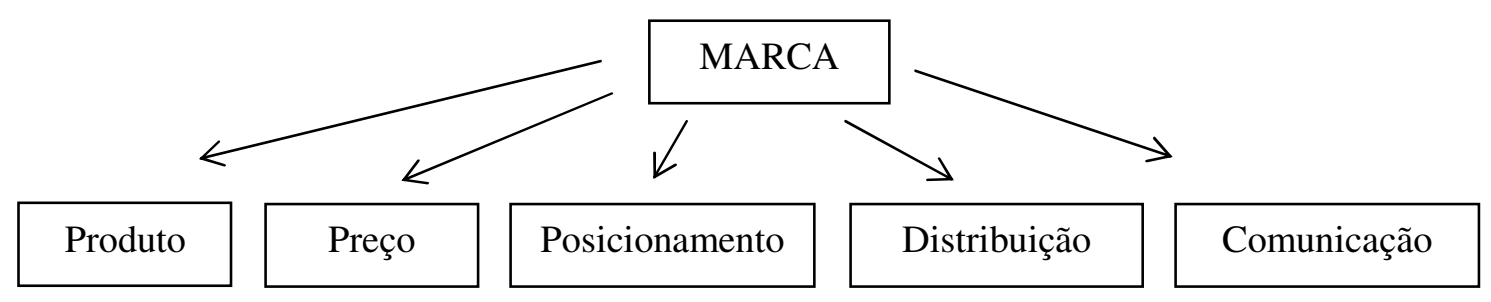

Conforme explica Semprini, "a passagem do marketing de mix para o mix de marca sanciona a passagem de um mercado em que se trocam bens e serviços, tornados atraentes e enriquecidos pela comunicação, para um mercado em que se trocam projetos de sentido, concretizados por produtos e serviços" (2006, p. 150). A dimensão simbólica torna-se então dominante, propondo um projeto de sentido a seus consumidores, e o produto, como um fazer-valer da marca, equipara-se a outros parâmetros, entre eles, devo destacar, a comunicação. Portanto, no mix de marca, a dimensão simbólica como lugar do abstrato e conceitual corresponde ao projeto da marca, e as dimensões do segundo nível, mais concretas e práticas, às manifestações da marca, que permitem exprimir e introduzir o projeto de forma concreta na vida dos indivíduos (Idem, p. 150-154).

Dessa forma, torna-se claro que é a partir do projeto que se desenvolve tanto a comunicação como o próprio produto, não o contrário. Por isso, neste trabalho, as análises se destinam primeiramente ao projeto da marca e somente depois a certas manifestações dela, a saber, as vinhetas institucionais no âmbito da comunicação e a programação da Rede Globo no âmbito do produto.

Assim, o primeiro capítulo, intitulado O Projeto da Marca, tem como proposta dar a conhecer a enunciação fundamental do símbolo que atualmente representa a Rede Globo como empresa televisiva. Embora outras logomarcas tenham anteriormente cumprido esse papel, meu foco de análise não recairá sobre elas. Em vista da necessidade de se estabelecer um recorte, chegarei a colocar lado a lado cada uma destas logomarcas da emissora, a fim de evidenciar as mudanças sofridas ao longo do tempo e apontar brevemente as características que limitaram suas existências, mas, depois disso, me concentrarei apenas no projeto que persiste, a marca elaborada por Hans Donner.

No segundo capítulo, denominado Do projeto à comunicação da marca, passarei a analisar as manifestações da marca no âmbito da comunicação, ou mais especificamente as vinhetas institucionais da Rede Globo, visto que estas são hoje o principal meio de 
promoção da marca televisiva. É por meio delas que a marca se dá a conhecer de maneira muito mais eficaz que em outros tipos de manifestações, como o uso de papel timbrado, pintura de veículos ou mesmo anúncios em outras mídias, e pode ser explorada a fim de colocar em evidência as diversas nuances de sentido que participam de seu projeto. E considerando que as vinhetas institucionais - como toda produção audiovisual da televisão - se confirguram a partir de um sincretismo de linguagens, quer dizer, o acionamento de diversas linguagens de manifestação, o segundo capítulo buscará enfocar a participação desses dois elementos sensoriais, a visão e a audição, nos quais diversas linguagens podem se increver para a conformação de um sentido identitário. Isso envolve considerar, tanto num caso como no outro, a articulação de sistemas semióticos de tipo linguístico (língua natural), paralinguísticos (proxêmica, gestualidade, ruídos, etc.) e não-linguísticos (vestimenta, cenário, música) (MÉDOLA apud OLIVEIRA, 2009, p. 56-57).

No terceiro capítulo, Da comunicação da marca ao produto, a abordagem recai sobre programação televisiva da Rede Globo - lembrando que no atual mercado pósmaterial, como bem exprime o modelo do mix de marca, o produto não é "nem oposto, nem complementar, nem suplementar à marca, ele é sua manifestação" (SEMPRINI, 2006, p. 153), pois, de fato, é o que permite introduzir o projeto de forma concreta na vida das pessoas. Assim, tentarei explicitar o perfil identitário que a emissora projeta a partir da escolha e da disposição dos conteúdos que oferta na grade televisiva e verificar se estes se mostram coerentes com o projeto da marca e suas manifestações no âmbito da comunicação.

Com isso, a noção de identidade surge neste trabalho como um processo de integração entre o projeto e suas manifestações, e de coerência entre um tipo de manifestação e outro - como é o caso da comunicação de uma marca e o produto dessa marca. No caso da Globo, entre as vinhetas e a programação. Embora todos esses aspectos sejam fundamentais na conformação de uma identidade televisiva, o papel das vinhetas ganha destaque na pesquisa, inclusive no título, porque foi a análise desse objeto que me permitiu chegar tanto à instância mais abstrata do projeto como à instância mais concreta do produto, visto que se achavam inscritos nas diversas produções analisadas. O resultado de todo esse trabalho se encontra nas próximas páginas.

Ao final, há um apêndice chamado Vinheta de TV: tipos, usos e funções. Nele está uma breve retrospectiva da trajetória das vinhetas na televisão como um todo e não apenas na Globo que, ao surgir, já podia usufruir de algumas conquistas em termos de linguagem e 
formas de inserção das vinhetas na grade. Tal retomada busca explicitar como as vinhetas ao longo da história foram pouco a pouco se tornando o principal meio de publicidade e propaganda da própria televisão - seus produtos e sua marca - e, finalmente, como essas produções são utilizadas atualmente na constituição de uma estética televisiva. Visto que este apêndice promove uma importante contextualização do objeto a ser estudado - a vinheta televisiva - sugiro que a leitura do trabalho seja iniciada por ele. 


\section{Capítulo 1 \\ O Projeto da Marca}

De acordo com Semprini, a marca é o ponto culminante de três dinâmicas diferentes: a da produção, a da recepção e a dos elementos contextuais. Todavia, a maior parte dos modelos conhecidos - como a star strategy de Jaques Séguela, o modelo cognitivista de Kevin Keller, a rosácea de marca de Marie-Claude Sicard e o elemento de integração de Jean-Marie Floch - tende a reconstituir a identidade de marca a partir de um único ponto de vista e, ao ignorar os demais, proporcionam apenas uma visão parcial sobre ela (2006, p. 155).

A fim de contornar essas dificuldades, Semprini propõe a formalização do processo constitutivo de uma marca e sua identidade em várias etapas. São elas: 1) a proposição de uma enunciação fundamental, que responde pela verdadeira razão de ser da marca e justifica a legitimidade de sua existência; 2) a transformação de tal enunciação fundamental em promessa, levando em consideração o público ao qual a marca se dirige e o contexto em que se insere; 3) a especificação da promessa, o que garantirá à marca um caráter específico e original; 4) a inscrição da promessa em um ou vários territórios, apontando sua área de atuação; e 5) os valores da marca, que definirão o tipo de abordagem a ser privilegiada.

Conforme explica o autor, "a identificação e análise destes elementos são de importância crucial para definir a identidade e o potencial de uma marca, pois eles concorrem para definir o conjunto das possibilidades, a partir dos quais toma forma o projeto de uma marca" (SEMPRINI, 2006, p. 163-164). Sendo assim, procederei nas próximas páginas à análise da logomarca da Rede Globo a fim de explicitar os elementos que constituem o seu projeto de marca, coforme as cinco etapas formalizadas por Semprini. 


\subsection{Construção e estabelecimento}

Em quase 50 anos de história, a Rede Globo teve apenas três marcas diferentes. A primeira delas foi criada por Aluísio Magalhães ${ }^{1}$, em 1965. Era uma rosa dos ventos estilizada, com quatro pontas, em referência ao canal "4" em que a emissora era sintonizada. A segunda foi o globo terrestre desenhado por Mauro Borja Lopes², em 1970, que acabou sendo acompanhado por anéis em 1974 em referência às afiliadas da época. Finalmente, em 1975, Hans Donner ${ }^{3}$ criou o conceito que permanece no ar até hoje.

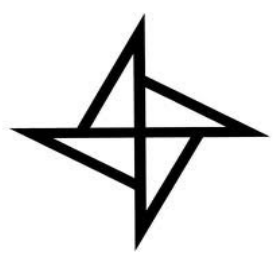

1965

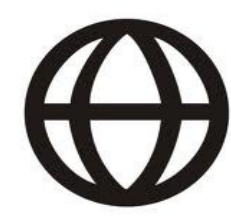

1970

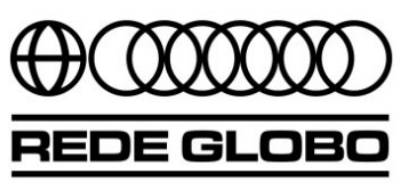

1974

Fig. 1: Vinheta - Logomarcas da Globo- I

Como se vê, nenhum dos desenhos é aleatório. A linguagem figurativa, apesar de certa economia de traços, especialmente nas duas primeiras logomarcas, está repleta de significações. Mas nem a rosa de ventos de Aluísio Magalhães, nem o globo de Borjalo conseguiram explorar realmente a ideia de televisão. A logomarca só começou a conquistar

\footnotetext{
${ }^{1}$ Aluísio Magalhães é considerado um dos mais influentes designers do séc. XX. Nome de referência nas décadas de 60 a 80, conquistou projeção internacional ao articular traços distintivos da cultura brasileira e a tendência dominante do design gráfico que, naquele momento, era representada pelo racionalismo suíço. De acordo com Escorel, ninguém, em tão pouco tempo, conseguiu conferir ao design brasileiro uma aura de respeitabilidade tal como Aluísio. Isso graças a seu senso de ocasião e a alta qualidade de sua inteligência projetual. Entre suas obras estão o símbolo da bienal internacional de São Paulo; o símbolo IV Centenário da cidade do Rio de Janeiro; o projeto para as notas do Plano Cruzeiro; projetos de identidade visual para empresas como Banco Nacional, Banespa, Sousa Cruz, Petrobrás e Light (ESCOREL, 2000 apud SILVA et all., 2010).

${ }^{2}$ Mauro Borja Lopes foi escolhido, em 1955, como um dos sete melhores caricaturistas do mundo durante o Congresso Internacional de Caricaturas de Bordighera (Itália), com trabalhos publicados no The New York Times e Paris Match. Segundo Lima, "Borjalo ficou conhecido por seus personagens de traços simples (desenhados sem boca e, na maioria das vezes, sem diálogo)" (2007, p.8). É também o criador dos "bonecos andantes" (caricaturas feitas em massa e movimentadas por molas). Na televisão, alguns de seus trabalhos são a vinheta do "plim-plim" e a zebrinha que anunciava o resultado da loteria esportiva, ambos na Globo.

${ }^{3}$ Hans Donner é um artista conhecido e elogiado internacionalmente. Foi o primeiro a utilizar a computação gráfica na televisão e seus trabalhos marcam a passagem do design estático para o de movimento. Uma das principais características dos objetos que compõe, dentro e fora da televisão, é a tridimensionalidade ou noção de volume. Em 1979, foi convidado a expor seus trabalhos de design em torno da marca da Globo na galeria Mecanorma, no Centro de Paris; posteriormente também em Roma, Londres, Edimburgo, São Paulo, Rio de Janeiro e Nova York. Em 1986, foi responsável pela criação da marca e do filme comemorativo dos dez anos do centro Georges Pompidou de Paris. E é o criador do Time Dimension, relógio futurista que abre mão de números e ponteiros para trabalhar com variações de claro e escuro (DONNER, 1996).
} 
essa dimensão em 1974, quando se somou ao desenho de 1970 os anéis que representavam as afiliadas da emissora e, portanto, a concepção de uma televisão em rede.

As alterações até chegar ao desenho de Hans Donner caminharam, portanto, no sentido de uma adequação da marca ao produto. Embora tenham respondido às necessidades de divulgação e diferenciação em relação à concorrência nos primeiros anos, essas três primeiras logomarcas não foram - nem poderiam ser - realmente capazes de acompanhar o desenvolvimento da empresa: a rosa dos ventos por causa da diferença de canal em que se sintoniza a emissora conforme a região do país; o globo terrestre por representar apenas o nome Globo, sem fazer menção ao produto televisivo; e o globo com os anéis por trabalhar com um número restrito de afiliadas.

O que se tem nessas primeiras logomarcas é a exploração de aspectos muito pontuais em vez de uma ideia mais abrangente e complexa, que levasse em conta elementos fundamentais como os destacados por Semprini e pudesse, assim, configurar um projeto de marca que desse sustentação não apenas para o presente imediato da empresa televisual, mas, sobretudo, para os seus desenvolvimentos no futuro.

Isso veio em 1975, com Hans Donner. A marca fundada sobre uma esfera dentro de um retângulo posicionado dentro de outra esfera exprimia figurativamente uma relação de objetos englobados e englobantes bastante profícua para a televisão, conforme se poderá ver nas considerações que seguem.

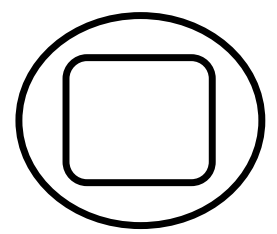

ENGLOBANTE $v s$. ENGLOBADO (esfera)
ENGLOBANTE vs. ENGLOBADO (retângulo)

(esfera)

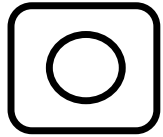

Embora esfera e retângulo desempenhem tanto a função de englobante como a função de englobado é importante reconhecer que isso se dá sob condições muito diferentes. Em primeiro lugar, porque há apenas um retângulo no desenho original, o que indica que o objeto por ele representado desempenha simultaneamente as duas funções englobado e englobante. Em segundo, porque as duas esferas apresentadas diferem tanto 
no tamanho quanto na posição que ocupam, indicando que o papel de englobante e o de englobado neste caso recaem, cada um, sobre objetos distintos apesar dos traços que guardam entre si - a esfericidade, evidentemente, mas também certo achatamento nos polos e o caráter de suspensão, pois tanto a esfera maior quanto a menor se sustentam sobre o nada. Todos esses apontamentos podem, então, nos conduzir a um esquema ainda mais explícito:
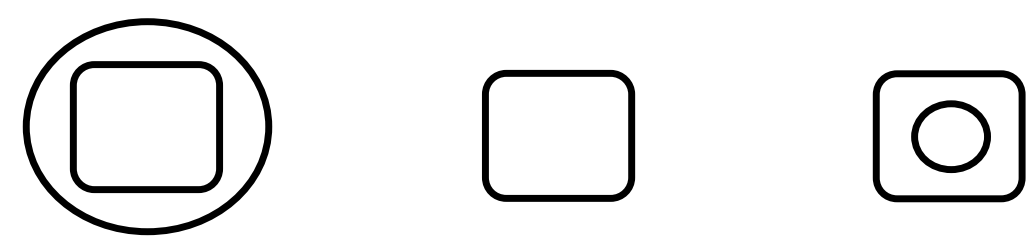

Esfera

Expressão:

Englobante

Maior

Exterior

Sem enquadramento

Conteúdo:

Absoluto
Retângulo Englobado/Englobante

vs.

$v s$.

$v s$.

$v s$.
Esfera

Englobado

Menor

Interior

Enquadrado

Relativizado

Tem-se assim um símbolo recursivo constituído por três partes: 1) uma esfera maior, englobante, exteriormente posicionada em relação às outras formas desenhadas e que, em decorrência disso, apresenta-se de maneira absoluta, sem qualquer tipo de limitação ou enquadramento; 2) um retângulo posicionado de maneira intermediária entre as esferas, desempenhando, assim, simultaneamente o papel de englobado e englobante; e 3) uma esfera menor, no interior da forma retângular, sendo por ela limitada, enquadrada e, consequentemente, relativizada.

Em termos figurativos, a forma do retângulo, especialmente pela proporção 4:3 que apresenta, nos remete à ideia de televisão. E a forma esférica, achatada nos polos e flutuante - reforçada pelo próprio nome Globo da emissora - ao globo terrestre. Assim, a esfera maior, exterior e absoluta não apenas se difere da esfera menor, interior e relativizada como isso se dá, na logo, justamente pela presença intermediária de uma tela de TV. Dessa forma, é possível enxergar temporalmente nesse símbolo um antes, um durante e um depois - o que caracteriza, de acordo com o antropólogo André LeroiGourhan (apud Floch), um pictograma: 
O que caracteriza o pictograma, e sua ligação com a escrita, é a linearidade: como no caso de um alinhamento sucessivo de fases de uma ação... Pode-se estender isso a uma ação em que o gesto evoca o desenrolar do tempo, como se vê nas cavernas de Lascaux: o homem derrubado por um bisão é um pictograma, quer dizer, é uma imagem que tem um passado, um presente e um futuro... (FLOCH, 1995, p. 50) ${ }^{4}$.

Assim, a logomarca da emissora expõe de maneira mais ou menos complexa um estado de transformação operado pela televisão, que parte do mundo natural e nos oferece dele uma representação. Esse sentido, como acabei de abordar, recai sobre uma dimensão diacrônica, quer dizer, de fases que se sucedem no tempo. Todavia, os três elementos que compõe a marca nos são apresentados simultaneamente - e indissociavelmente também, como um conjunto, um todo de sentido. Exigindo, portanto, uma análise de dimensão sincrônica.

Destaco a dupla natureza temporal que atua sobre o símbolo da Globo por causa das similaridades que ela guarda com o processo que Levi-Strauss postulou acerca da edificação dos mitos, em que a co-existência de um tempo diacrônico e sincrônico nos permite perceber uma estrutura permanente - a partir do que o autor chamou de feixes de relações - que se relaciona com o presente, o passado e o futuro da narrativa:

Supomos, com efeito, que as verdadeiras unidades constitutivas do mito não são as relações isoladas, mas feixes de relações, e que é somente sob a forma de combinações de tais feixes que as unidades constitutivas adquirem uma função significante. Relações que provêm do mesmo feixe podem aparecer em intervalos afastados, quando nos situamos num ponto de vista diacrônico, mas se chegamos a restabelecê-las em seu agrupamento 'natural', conseguimos ao mesmo tempo organizar o mito em função de um sistema de referência temporal de um novo tipo (...) este sistema é de duas dimensões: ao mesmo tempo diacrônico e sincrônico (LEVI-STRAUSS, 1985,p. 143).

\footnotetext{
${ }^{4}$ Tradução livre. No original: Ce qui caractérise le pictogramme, dans ses liens avec l'écriture, c'est sa linéarité: comme c'est le cas dans l'alignement sucessif des phases d'une action... On peut étendre cela même à une action où le geste évoque le déroulement du temps, comme on le voit à Lascaux: 1'homme renversé par le bison, c'est un pictogramme, c'est-à-dire une image qui a un passé, um présent et un futur...
} 
Levi-Strauss aponta, portanto, para a existência de elementos que se repetem de maneira idêntica ou parcial ao longo de uma narrativa e podem, apesar de seu aparente distanciamento no tempo, estabelecer analogias entre si. Num caso assim, tais elementos devem ser abordados não somente pela ordem sucessiva que os instala, mas devem ser apreendidos globalmente também, a partir dos feixes de relações que se estabelecem. Isso porque, como bem colocam Greimas e Cortés acerca do trabalho do antropólogo, tais percursos de leitura - diacrônico e sincrônico - possuem funções distintas:

na sua análise estrutural do mito de Édipo, C. Lévi-Strauss considera a leitura do nível prático (o termo não é dele) como horizontal (isto é, sintagmática), enquanto a interpretação do nível mítico seria vertical, de ordem paradigmática, permitindo reconhecer, pela recorrência no texto de superfície, uma organização dos conteúdos que pode ser formulada como o correlacionamento de duas categorias binárias de semas contraditórios ou contrários. Tal interpretação permitiu o reconhecimento da existência, nas profundezas do discurso, de estruturas semióticas que comportam uma sintaxe e uma semântica fundamentais; e ao mesmo tempo, fez o discurso mítico perder sua especificidade: estruturas semióticas comparáveis regem os discursos poéticos, oníricos, etc. Logo, a dicotomia prático/mítico deixa de ser operatória: o nível prático identifica-se com o plano figurativo do discurso, enquanto o nível mítico corresponde, no percurso gerativo, às organizações semióticas profundas"(1983, p. 281).

Assim, partindo dos elementos expressivos que venho propondo e de oposições como /englobante/ vs. /englobado/, /absoluto/ vs. /relativizado/ e /mundo natural/ vs. /mundo representado/ explicitadas nos parágrafos anteriores, pode-se chegar a termos mais amplos. Finalmente, /natureza/ vs. /cultura/. Esses dois valores estão presentes na logomarca da Globo e, na dialética que mantém entre si, conformam um projeto "mitológico" para a marca - quer dizer, que não apenas admite a co-existência de tais valores contrários mas, sobretudo, se funda sobre eles.

Sob esse prisma, a posição intermediária que o retângulo ocupa entre as duas esferas mostra-se bastante significativa porque coloca a televisão como o elemento transformador ou de passagem de um estado a outro - de natureza à cultura e de cultura à 
natureza. Tal "poder-fazer" se explicita na disposição das formas: estar o retângulo no centro da esfera exterior dá à televisão o status de uma mídia socialmente instituída. Porém, o retângulo não está vazio. Em seu próprio centro está a esfera menor, tornando evidente não apenas o fato de que a televisão se volta para a sociedade que a instituiu, mas, principalmente, que estas próprias representações são igualmente centrais para tal sociedade - do espetáculo? Guy Debord diria que sim:

\begin{abstract}
Não se pode contrapor abstratamente o espetáculo à atividade social efetiva; este desdobramento está ele próprio desdobrado. $\mathrm{O}$ espetáculo que inverte o real é produzido de forma que a realidade vivida acaba materialmente invadida pela contemplação do espetáculo, refazendo em si mesma a ordem espetacular pela adesão positiva. A realidade objetiva está presente nos dois lados. O alvo é passar para o lado oposto: a realidade surge no espetáculo, e o espetáculo no real. Esta alienação recíproca é a essência e o sustento da sociedade existente (DEBORD, 2003, p. 16).
\end{abstract}

Torna-se evidente, desse modo, a influência que os dispositivos midiáticos têm sobre as práticas sociais e como estas mesmas práticas reforçam o poder ou centralidade dos meios. Esse sentido está expresso na oposição "natureza" vs. "cultura" que venho abordando até aqui, e é sobre ele que se edificam os discursos da Globo.

Voltando, então, às etapas que devem ser levadas em conta ao se elaborar o projeto de uma marca, conforme propõe Andrea Semprini, pode-se dizer que a logo criada por Hans Donner exprime a função de mediação como sua enunciação fundamental. Tal princípio de abordagem da marca se inscreve sob a promessa de intensa interação entre o meio e a sociedade, e se especifica numa proposta de nível global - em vez de local, regional ou mesmo nacional. E, por fim, o território de atuação em que a logo se coloca, como evidencia a figura do retângulo, é o da televisão - e não o de outro meio qualquer, como o rádio ou o jornal.

Mas Semprini fala de cinco etapas constituintes do projeto da marca, e não de quatro. Falta, portanto, o quinto e último componente, que responde pelos valores da marca. Estes permitem a ela se coligar a valores contextuais e socioculturais, se posicionando frente ao público. Além disso, são responsáveis por animar e condicionar não apenas as escolhas das manifestações da marca, mas também as maneiras de realizar e 
comunicar tais escolhas. De modo que se pode encontrar neles uma dimensão de conteúdo, relativa aos tipos e às escolhas de manifestações, e uma dimensão de expresssão, relativa à maneira de colocar em cena e de comunicar estes mesmos valores (SEMPRINI, p. 163).

No caso da Globo, pode-se observar, por exemplo, que a logomarca é geometrizada e bastante econômica, quer dizer, construída com base nas formas de apenas duas figuras, o círculo e o retângulo, sendo que o ângulo deste não é exatamente reto, mas ligeiramente arredondado, fazendo prevalecer a esfericidade - o que dá ao desenho certa leveza. Nesse sentido, deve-se ainda destacar que os traços são de tipo fino em vez de espessos. Os círculos estão suspensos, como que flutuando sobre o nada, pois não há imediatamente sob eles qualquer objeto de apoio, e o trabalho de luz e sombra cria para as figuras um efeito de profundidade capaz de atribuir não apenas tridimensionalidade aos objetos como fazer a separação entre fundo e frente, como que instalando o objeto em seu cenário. Por fim, a centralidade da imagem e a disposição equidistante das figuras que a compõe primam pelo equilíbrio em vez do desiquilíbrio. Todas essas características que conformam o plano de manifestação da marca refletem a escolha pelo que se pode chamar de estilo clássico $^{5}$.

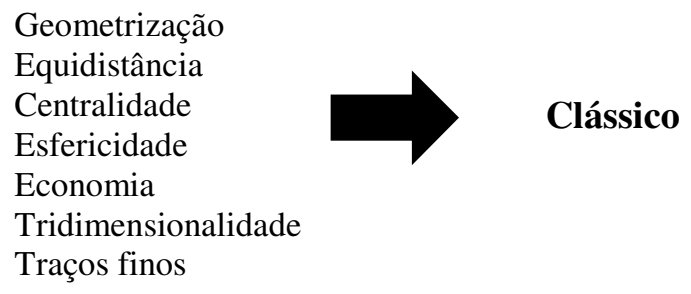

De acordo com Omar Calabrese, tal estilo é caracterizado por fênomenos de ordem, estabilidade e simetria (1999, p. 206). Exatamente o que se vê na logomarca da Globo. Por se apresentar como um valor norteador, tal estilo se mantém e, de certo modo, organiza todos os tipos de manifestações da marca, compondo uma estética identitária a partir da articulação coerente, original e persistente dos elementos significantes. Para ilustrar como isso acontece, destacarei a utilização de dois dos recursos expressivos que apontei anteriormente: a tridimensionalidade e a geometrização das figuras.

\section{Tridimensionalidade}

Apesar de não se ter muitas amostras do que era feito na Globo em termos de vinheta institucional antes de 1975 - devido aos incêncidios sofridos pela emissora e a

\footnotetext{
${ }^{5}$ Cf. Apêndice - Vinheta de TV: tipos, usos e funções.
} 
consequente perda de material -, no filme publicitário $O$ que é bom está na Globo as imagens aparecem majoritariamente num mesmo plano, com poucos efeitos de perspectiva ou volume. As logomarcas nessa época eram planares e é provável que as vinhetas seguissem esse mesmo molde. Mas com Hans Donner isso muda porque a ideia de uma "televisão dentro do mundo e do mundo dentro da televisão" que ele havia criado para representar a Globo estava alicerçada num conceito de tridimensionalidade e isso exigiu, por consequência, uma concepção diferente no modo de produzir os novos vídeos.
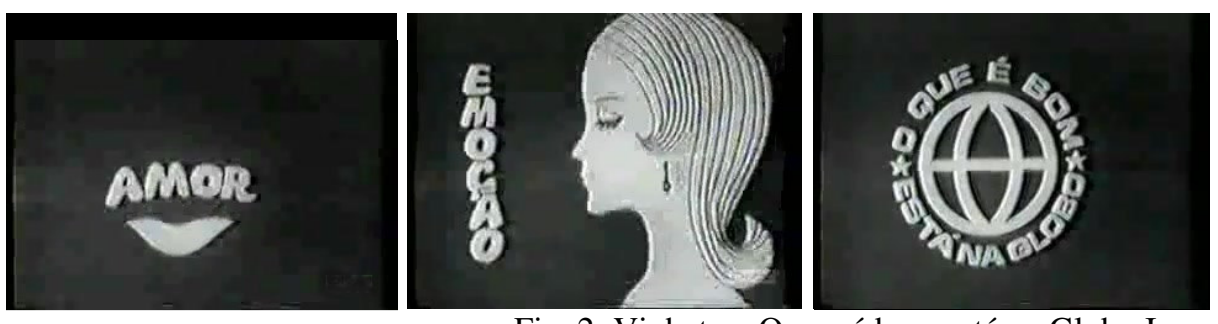

Fig. 2: Vinheta - O que é bom está na Globo I

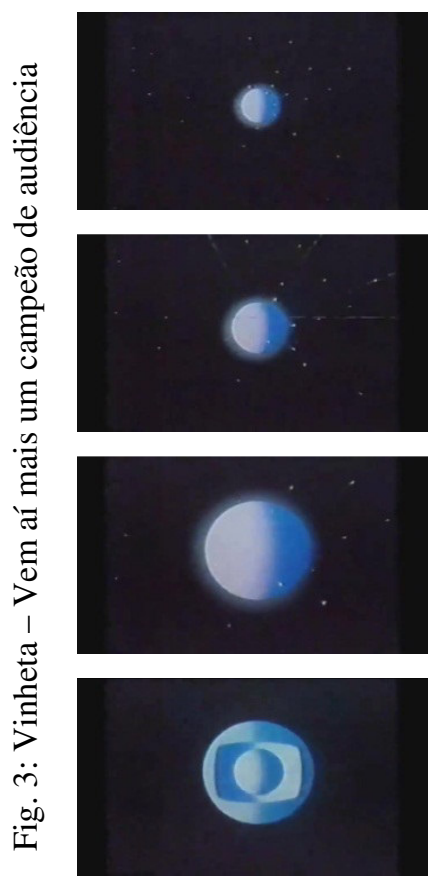

Na horizontal: vinheta

"O que é bom está na Globo”, com figuras planares;

Na vertical: vinheta "Vem aí mais um campeão de audiência”, de 1976.

A logomarca possui efeito de tridimensionalidade $e$ se movimenta do fundo para a frente da tela, provocando efeito de profundidade.

Assim, se nos primeiros dez anos da Globo a logomarca da emissora tinha por característica ocupar uma mesma linha de profundidade e contava com apenas alguns poucos movimentos laterais de entrada e saída de imagens do quadro, passa a haver de 1975 a 1984 "um movimento mais consistente, com relação ao período anterior, e que vai ganhando complexidade" (MUANIS, 2011, p. 120). Em primeiro lugar porque a logomarca projetada por Hans Donner deixa de aparecer somente ao final das produções, como uma assinatura, e passa a ser ela mesma o elemento principal dos vídeos. E, em 
segundo, porque com o uso da computação gráfica as imagens começam a ganhar certa liberdade de movimento. As entradas e saídas laterais passam a ser mais exploradas e se inicia um trabalho sobre o eixo $\mathrm{Z}$, ou seja, de colocação de objetos também no fundo da tela (ibidem). De 1984 em diante as produções ganham novo impulso. O telespectador deixa de ser um mero observador para fazer parte da imagem do vídeo. Conforme explica Muanis, "o observador passa a ser o centro da ação. O seu olhar se confunde com o da câmera, e ele entra na ação" (ibidem). As imagens, portanto, não se restringem mais a movimentos laterais, de entrada e saída pelas bordas da tela; e o movimento do olhar sobre o eixo Z, da frente para o fundo da tela, simplesmente se inverte para alcançar, como seu prolongamento, o sujeito-telespectador que está fora do quadro.

\section{Geometrização}

O uso de figuras geométricas é uma constante nas vinhetas da Globo desde a marca criada por Hans Donner. São triângulos, quadrados, esferas, círculos e linhas projetados como que para representar apenas a si próprios, numa espécie de elogio à forma, embora sempre façam referência à logomarca da emissora e/ou alguma característica técnica da televisão.
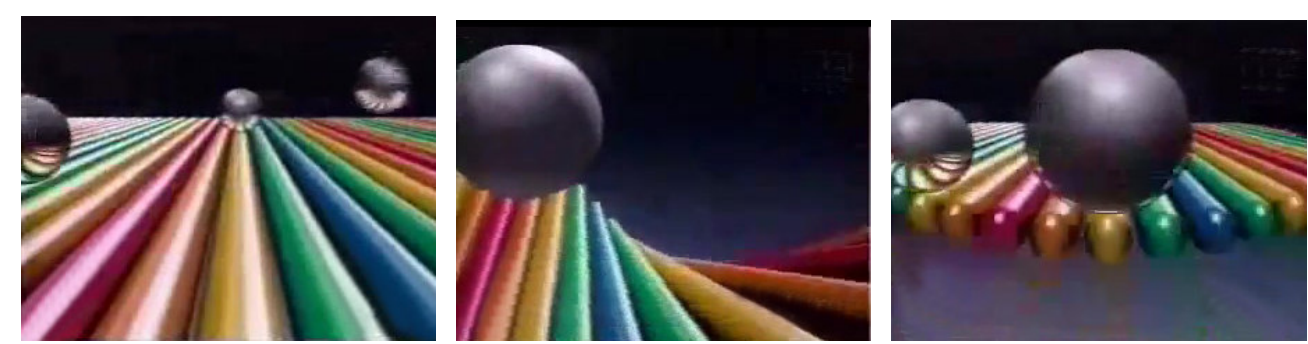

Fig. 4: Vinheta - Tubos coloridos (1980)
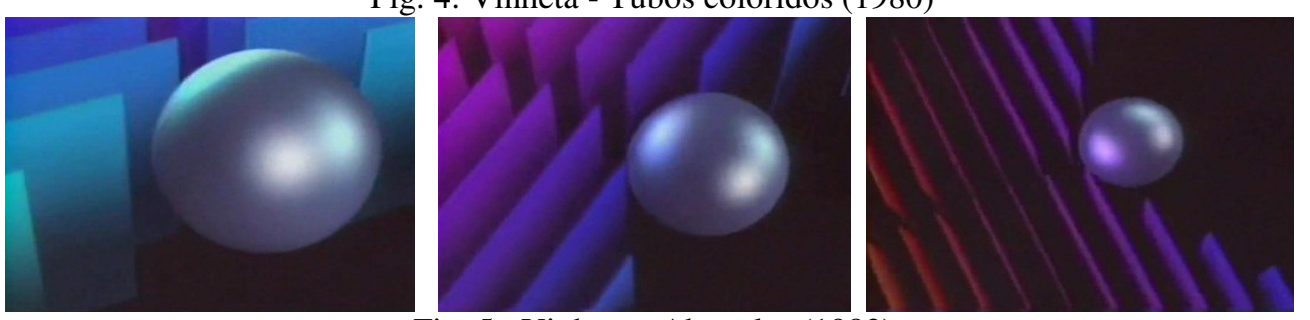

Fig. 5: Vinheta - Abre alas (1983)
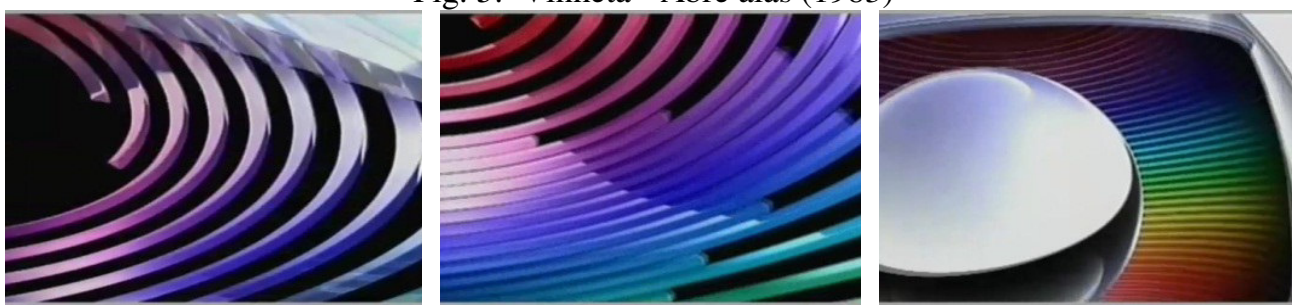

Referência às coresluz (verde, azul e vermelho) emitidas pelos tubos de raios catódicos; às linhas de varredura da televisão analógica; e à esfera platinada, símbolo da Globo.

Fig. 6: Vinheta - Interprogramas (2008) 
Evidentemente, esses elementos básicos do desenho também foram utilizados em algumas vinhetas para a representação de figuras do mundo natural. Mas mesmo nesses casos a economia da forma é bastante grande, colocando em destaque a figura geométrica de base. É o que acontece com a cidade futurista projetada numa das vinhetas de 1989, e das antenas de televisão de um vídeo institucional de 1993.

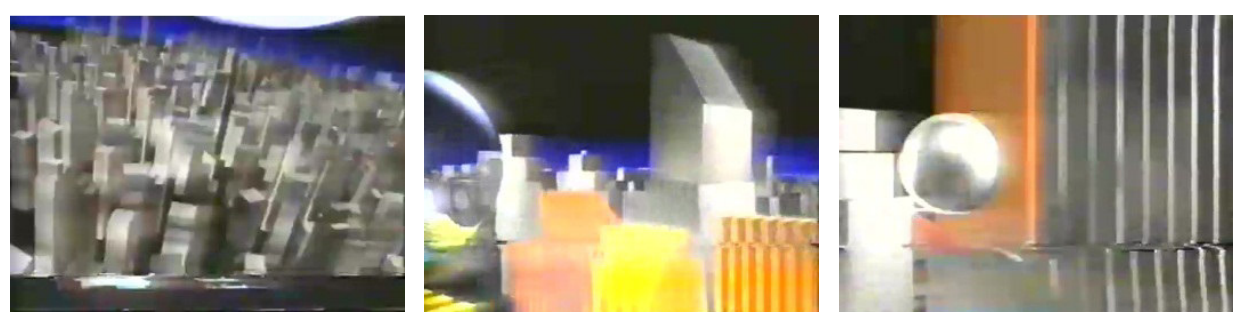

Fig. 7: Vinheta - Cidade futurista (1989)
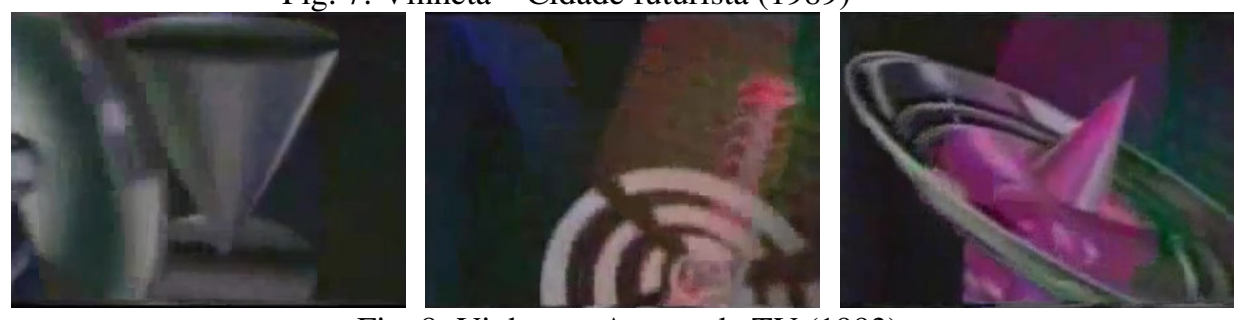

Fig. 8: Vinheta - Antena de TV (1993)

Além de configurar uma característica marcante de Hans Donner, o estilo limpo do design também confere modernidade às imagens, sentido reforçado pelo uso de tons de cinza e efeitos metalizados sempre presentes por causa da logomarca da Globo, produzida na época nesses moldes.

O posicionamento estético que se observa nestas e outras manifestações da marca não é aleatória. De acordo com Omar Calabrese, o estilo clássico tem por característica ser universal (p. 199-200). Tendo em vista a heterogeneidade do público para o qual uma televisão aberta se volta, torna-se compreensível o investimento da marca em formas abstratas, de caráter neutro, capazes de agradar - ou, pelo menos, não desagradar - a audiência como um todo ${ }^{6}$.

Assim, com base nos aspectos que abordei até aqui, pode-se dizer que a marca desenhada por Hans Donner na década de 70 conseguia expressar com simplicidade um estado de produção, de referências, de ambições e também de total simbiose entre o meio e a sociedade - e, sobretudo, entre a televisão e seu público. Com isso, é possível identificar em seu projeto duas das três dimensões-chave para o sucesso de uma marca no atual

\footnotetext{
${ }^{6}$ Cf. Apêndice I - Vinheta de TV: tipos, usos e funções.
} 
contexto pós-moderno: sua natureza semiótica ou capacidade de construir e veicular significados; e sua dimensão inter-subjetiva, resultante dos diversos jogos de posicionamento ou relações, inclusive contratuais, que se estabelecem entre os polos da emissão e recepção, tendo-se em conta o contexto geral em que estes se inserem (SEMPRINI, 2006, p. 103-122).

\subsection{Evolução}

Desde seu lançamento até hoje, a logomarca foi recriada sete vezes - em 1988, 1993, 1995, 2000, 2008 e 2014 - mas sempre dentro do mesmo conceito ${ }^{7}$.

Fig. 9: Logomarcas da Globo - II
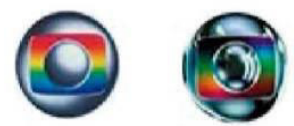

1993

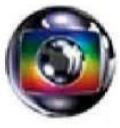

1995

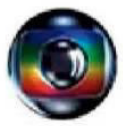

2000

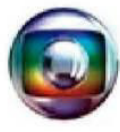

2005

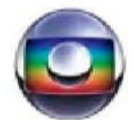

2008

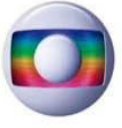

2014

Diferentemente dos desenhos de Aluísio Magalhães e Borjalo, que tiveram de ser mudados com fins de adequação ao produto, a logomarca de Hans Donner, com quase 40 anos de vida, sofreu alterações apenas de atualização. Mesmo assim, não se deve perder de vista a noção de comutação, central para a semiótica, segundo a qual toda mudança no plano da expressão corresponde a uma mudança no plano de conteúdo.

A comutação não é mais do que a explicitação da relação de solidariedade (da pressuposição recíproca) entre um plano da expressão e o plano do conteúdo de uma semiótica, segundo a qual a qualquer alteração da expressão deve corresponder uma alteração do conteúdo e viceversa (GREIMAS; COURTÉS, p. 60).

Tais alterações recaem, especialmente, sobre as cores, tonalidades e dimensões da logo. E, como tentarei evidenciar, não se trata apenas de dar à marca um ar sempre

\footnotetext{
${ }^{7}$ Imagens obtidas no site G1. Disponível em: http://g1.globo.com/economia/midia-e-marketing/noticia/2014/globo-anuncia-programacao-2014-eapresenta-nova-logomarca.html. Acesso em: 7 de abril de 2014.
} 
renovado, moderno, aprimorando os efeitos de tridimensionalidade, volume e liberdade no espaço intencionados já na concepção da marca, mas também de acompanhar o contexto político, econômico, social e tecnológico do país.

Isso porque as mudanças da marca coincidem com eventos marcantes da história do Brasil e da televisão. A primeira delas, por exemplo, ocorreu em 1988, ano da promulgação da Constituição Federal; a segunda é de 1993, quando o país, em plebiscito, optou pelo sistema presidencialista; a terceira, de 1995, comemora trinta anos da emissora e está no contexto do primeiro aniversário do Plano Real e do alcance da estabilização econômica no país; a quarta, de 2000, festejou os trinta e cinco anos da rede e também a virada do milênio (ou pelo menos a expectativa brasileira na época, já que a virada aconteceria, apenas, no ano seguinte); a quinta, de 2005, deu nova roupagem aos 40 anos da emissora; a sexta, de 2008, respondeu às mudanças de transmissão de áudio e vídeo instauradas pelo sistema HDTV e a estética do cinema que começava a surgir com os aparelhos no padrão 16:9, especialmente após o lançamento da televisão digital no final de 2007. E a mais recente alteração, apresentada em abril de 2014, dá início às comemorações dos 50 anos da Rede Globo, a serem completados nesse mesmo mês em 2015.

Assim, o símbolo da Globo teve três cores. A primeira delas, o azul, foi utilizado entre 1975 e 1988. Essa opção como cor original poderia ser justificada de diferentes maneiras, a partir de diferentes grades de leitura, como o fato de o azul ser a cor do céu, o cenário infinito sobre o qual o globo terrestre se sustenta, especialmente pelo fato de que ao projetar a marca Hans Donner estava literalmente nas alturas, à bordo de um avião; ou então pelo fato de o azul ser uma cor fria, motivo pelo qual parece se afastar para trás de seu plano, contribuindo para a noção de profundidade de campo intencionada na logo original; mas, particularmente, prefiro fazer prevalecer - sem, no entanto, descartar os demais sentidos - a ideia de que a própria “Terra é azul”, conforme Yuri Gagarin declarou ao descrever a primeira visão que teve do nosso planeta ao contemplá-lo do espaço ${ }^{8}$. De modo que esse sentido se alinha com o de mundo natural que descrevi inicialmente ao analisar o significado da esfera exterior que compõe o desenho da logomarca - e a partir do qual a televisão atua.

A segunda cor, o cinza, persistiu de 1988 a 2014, tendo sua tonalidade alterada em cada mudança da logo - marcando a passagem do tempo e, consequentemente, a existência

\footnotetext{
${ }^{8}$ Yuri AlekseyevichGagarin (1934-68), astronauta russo. A bordo do satélite Vostok 1, foi o primeiro homem a ir para o espaço, em 12 de abril de 1961 (GUIMARÃES, 2000, p.7).
} 
de diferentes contextos. Assim como no caso do azul, a escolha do cinza pode ser explicada sob diferentes pontos de vista. Por exemplo, o fato de essa cor ser o resultado da mistura entre o branco e o preto e, portanto, ser o termo médio entre todas as cores, dá a ela um caráter neutro - e, portanto, universal - bastante adequado ao estilo clássico presente na logo. Além disso, é possível destacar que em se tratando de cores-pigmento, "o gris é sempre composto por partes iguais das cores primárias" "GUIMARÃES, 2000, p. 72) cyan, magenta e amarelo. Essa característica da cor cinza poderia, então, representar os valores democráticos que em 1988 passavam a ser assegurados pela Constituição Federal. Mas, tendo em vista a trajetória da Globo, que até então buscava se diferenciar como empresa televisiva por investir pesadamente em aparatos tecnológicos capazes de proporcionar grande alcance e qualidade de imagem, prefiro eleger o sentido de modernidade - futurista, até - culturalmente associado ao cinza metálico como o principal valor intencionado na marca. E, seguindo nessa linha isotópica, tem-se também a mudança de 2008, quando o retângulo da logo deixou o formato 4:3 e passou a acompanhar o padrão 16:9 do cinema, em decorrência do sistema HDTV.

Por fim, em 2014, a cor cinza da logomarca deu lugar ao branco. Numa visada histórica, tal desenvolvimento da marca reflete mudanças do próprio contexto e da sociedade. Nesse sentido, vale a pena considerar que o valor de modernidade, presente muito fortemente a partir dos anos 80, mantinha estreita relação com um estado de produção e veiculação de conteúdos em que ter uma imagem de qualidade e um bom sinal de transmissão eram não apenas aspectos diferenciais - que colocavam em lados opostos as emissoras que tinham poder tecnológico e as que não tinham - mas, também, consequentemente, decisivos para garantir a audiência. Superada essa fase, a nova cor branca da logo aponta justamente para a necessidade de uma renovação de contrato com o público, pois os valores que se colocam no atual cenário social não giram mais em torno de um know-how tecnológico - tendo em vista o uso generalizado de alta tecnologia nas mais diversas redes - mas de questões ligadas à diversidade.

Nesse sentido, como se sabe, a cor branca é "formada pela soma das cores-luz primárias"10 (GUIMARÃES, 2003, p. 195) - vermelho, verde e azul - as cores mesmas do pixel, o menor elemento constituinte da imagem televisiva. Portanto, reside na escolha do branco um sentido de pluralidade para a televisão bem mais forte que na cor cinza anterior,

\footnotetext{
${ }^{9}$ Grifos meus.

${ }^{10}$ Grifos meus.
} 
cuja característica principal estava não na participação plena das cores, mas no equilíbrio entre suas partes - o que nos encaminha para a homologação das seguintes categorias: /cinza/ vs. /branco/ e /parcial/ vs./total/. Cinza e parcial no passado, branco e total no presente, colocando de maneira ainda mais nítida as mudanças da sociedade, que antes exigia um país democrático e agora exige maior visibilidade para os segmentos minoritários. Assim, gradativamente, a sociedade quer mais. Esse atual momento histórico - protagonizado pelas minorias sociais e sexuais - não passou despercebido, e os discursos plurais foram não só acolhidos na programação, mas também representados pelo uso da cor branca na própria logo.

O importante a destacar em todas essas alterações da cor - azul, cinza e branco - é que os valores que elas carregam - tanto em suas significações periféricas como, principalmente, nas significações centrais que busquei eleger e explicitar - apesar de conduzirem a abordagens distintas, em nenhum momento se contradizem nem apresentam qualquer incoerência em relação ao projeto da marca, pois se alinham perfeitamente à ideia de mediação que se fundamenta na logo pela oposição "natureza" vs. "cultura". Trabalhar em cima de aspectos do mundo natural, suportes tecnológicos ou da pluralidade do público significa, portanto, apenas contemplar diferentes lados de uma mesma questão sendo que continua a haver ainda muitas outras possibilidades, como buscarei ilustrar no próximo tópico. E, indubitavelmente, é nesse caráter amplo e complexo de sentido intencionado pelo projeto da marca que reside boa parte da longevidade do símbolo criado por Hans Donner.

\subsubsection{A marca da Globo em diferentes tipos de materiais}

Ao longo dos anos, Hans Donner fez algumas experimentações em sua logomarca. Chamo tais aparições de experimentações porque diferentemente das mudanças que citei anteriormente - da cor azul para o cinza e do cinza para o branco - elas não tiveram a intenção de substituir a logo vigente, mas expressar o posicionamento da marca diante de contextos específicos e, em alguns casos, explorar a própria enunciação fundamental da marca - a função de mediação da televisão. Vejamos três casos: 


\section{Bolha de sabão}
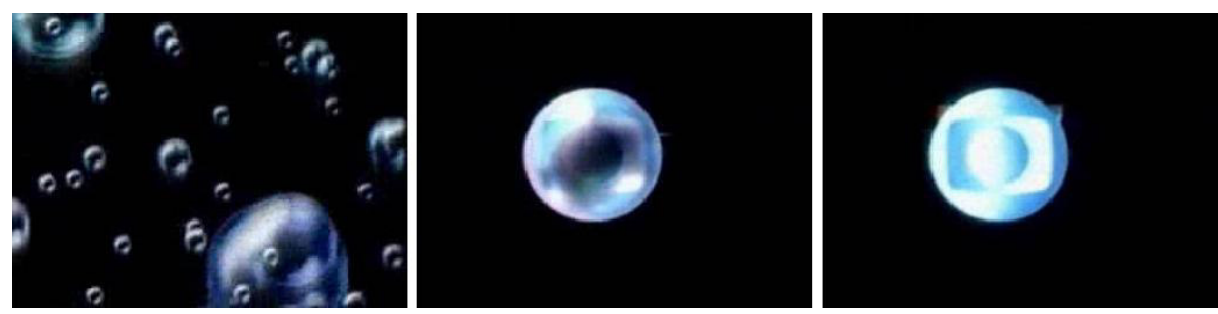

Fig. 10: Vinheta - Bolhas de sabão

A comparação entre a estrutura, beleza e graça da bolha de sabão com a logomarca da Globo apareceu pela primeira vez numa vinheta de 1977. O objetivo principal da metáfora era marcar o uso sistemático de cores na grade televisiva. Até então apenas algumas novelas e o jornalismo haviam sido transmitidos dessa maneira. De acordo com Walter Clark (1991, p. 239), o processo de colorização na Globo só terminou por volta de 1977, quando a empresa teve equipamento e experiência suficientes para operar a programação integralmente no novo sistema. Quanto à bolha de sabão, como se sabe, sempre que é iluminada por luz branca, como a do sol, ela reflete todas as cores que formam o espectro de luz visível ao olho humano - as mesmas cores que estreavam na programação.
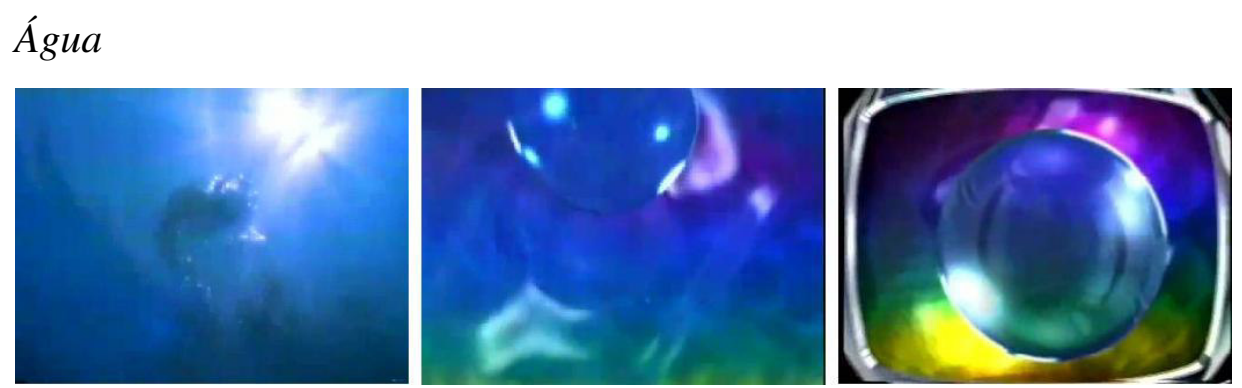

Fig. 11: Vinheta - Globo 2000, no coração do Brasil

A logomarca da Globo também já teve as dimensões sensíveis de um corpo d’água e, em certo sentido, por razão semelhante a das bolhas de sabão: o efeito arco-íris, em referência a colorização da TV. Mas esse sentido não é o único e, no exemplo que utilizei, tampouco é o principal. Trata-se da vinheta Globo 2000, no coração do Brasil, exibida em 1999. Com essa frase, a emissora buscava destacar eventos futuros e ao mesmo tempo posicionar-se junto ao seu público. Era, portanto, um enunciado com duas dimensões de sentido, representados, pois, nestas duas partes: "Globo 2000" e "no coração do Brasil". 
A expressão visual da vinheta foi buscar no elemento água o recurso que precisava para articular e dar certa unidade a esses dois sentidos, tal como faz o enunciado verbal. Assim, tem-se uma imagem que trabalha basicamente as oposições "fundo" $v s$. "superfície" e "interior" vs. "exterior" capazes de atrelar aspectos topológicos comuns tanto à ideia de nascimento ou renascimento, claramente figurativizada no primeiro quadro (“dar à luz", lembrando que a vida começa sempre na água ou envolta por ela) em referência ao início de um novo ciclo - “Globo 2000” - marcado não só pela transição de um ano para outro mas, sobretudo, de um milênio para outro; como também a ideia de âmago ou o lugar dos nossos mais profundos sentimentos - "no coração do Brasil" - para estabelecer o lugar afetivo em que a emissora queria se posicionar no dia a dia do telespectador.

A logo que vimos surge num contexto em que a questão ambiental é bastante valorizada e o uso da água como elemento expressivo, como este da vinheta de 1999, revela uma marca bastante atenta ao seu entorno econômico, ambiental e social, e que se mostra consciente, portanto, das preocupações e valores que se integram pouco a pouco ao repertório de seu público e a respeito dos quais este reclamará uma posição das marcas que consome - inclusive dela própria, a televisão. Sabendo o que importa para o público e adiantando-se em demonstrar que contempla igualmente tais questões, ficou mais fácil para a Globo requisitar um lugar no "coração do Brasil".

\section{Vidro}

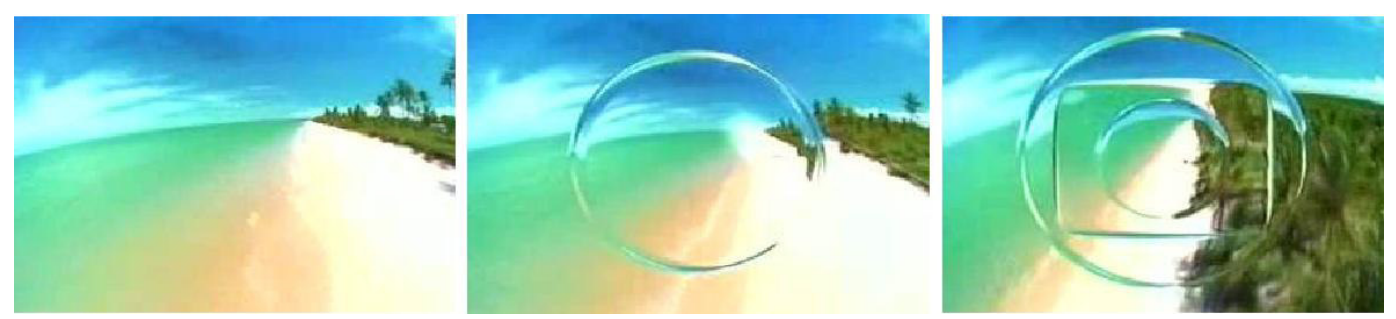

Fig. 12: Vinheta - A gente se vê por aqui

O globo de vidro surgiu em 2001, com o slogan A gente se vê por aqui. A ideia de que as pessoas podiam se ver através da tela da Globo se alinhava perfeitamente à transparência do material. E este, mais que qualquer outro elemento, soube traduzir a essência da marca criada por Hans Donner. A vinheta articulava, portanto, conceitos como "opacidade" vs. "transparência", em referência à logomarca metalizada e a então logo de vidro. E colocava em foco pontos turísticos e belezas naturais de todo o Brasil, integrando 
até as partes mais longínquas e esquecidas do território nacional ao mundo que o projeto da marca se propõe dar a ver.

Assim, a partir de uma lente grande angular, que distorcia as imagens e dava a elas a forma circular do planeta - como se as pessoas estivessem realmente vendo o mundo pela televisão - a Rede Globo deu não só visibilidade às diversas regiões do país, mas também as colocou em pé de igualdade entre si e elevou todo o conjunto à importância de "mundo" também, ou parte integrante dele. De modo que a vinheta colocava na tela valores caros à sociedade, como o sentido de integração, pertencimento e orgulho nacional.

\subsubsection{Atualizações e experimentações}

Todas essas atualizações e experimentações chamam a atenção para a terceira dimensão-chave da marca pós-moderna, também presente na logomarca da Globo: sua natureza evolutiva. "Nesta perspectiva, pode-se considerar a marca como uma entidade viva, que reage, sensível a todas as mudanças de seu ambiente" (SEMPRINI, p. 117). Entra em evidência, desta forma, a capacidade da marca em se "adaptar às evoluções do sistema, permanecendo ela mesma, quer dizer, fiel, mas em uma flexibilidade e adaptação a seu projeto original" (Idem, p. 119). Sem esse equilíbrio haveria não somente um hiato entre a marca e seu contexto de uso, mas, consequentemente, entre a marca e seu público. Em primeiro lugar porque se o dinamismo do contexto não tiver qualquer influência sobre a marca ela certamente se tornará anacrônica; e, em segundo, porque se tiver influência demais fatalmente fará com que o projeto original caminhe para uma descaracterização. E nos dois casos haveria uma quebra de contrato.

No caso da Globo, a empresa parece ter encontrado o meio termo necessário para sobreviver às alterações do contexto ao longo do tempo. Apesar das mudanças apontadas nos parágrafos anteriores, a manutenção das formas básicas em suas posições originais "esfera", "retângulo", "esfera" - permitiu o contínuo reconhecimento da marca pelo público, funcionando, nos termos colocados por Greimas e Courtés para o verbete identidade, como o "conjunto de traços que dois ou mais objetos têm em comum", "o princípio de permanência que permite ao objeto continuar o 'mesmo', 'persistir no seu ser', ao longo de sua existência" (1989, p. 223-224) - fixando, assim, uma imagem identitária: dotada de sentido e pregnância. 


\section{Capítulo 2 \\ Do projeto à comunicação da marca}

No capítulo anterior, analisei os elementos expressivos do símbolo criado por Hans Donner a fim de descobrir o projeto por trás da marca. Retomando os pontos mais importantes, vimos que para a Globo a função de mediação constitui a razão de ser da emissora (enunciação fundamental). E que para isso ela se propõe a investir numa forte inteiração entre o meio e a sociedade (promessa). Sua proposta é de nível global (especificação da promessa) e se concentra no âmbito da televisão (território), destacando aspectos como a tecnologia e a pluralidade do público (valores). Tudo dentro de um estilo clássico.

Visto que, em geral, "em uma marca bem construída do ponto de vista de suas manifestações, é a lógica da redundância que domina, por razões evidentes de eficácia e de clareza da enunciação do projeto da marca" (SEMPRINI, 2006, p. 171) tentarei explicitar como os aspectos que embasam o projeto são retomados e explorados nas principais manifestações da marca em termos de comunicação, as vinhetas institucionais.

Considerando que tais manifestações se situam sempre na esfera do sensível e que no caso das vinhetas institucionais múltiplas formas de registro são articuladas, convocando diferentes órgãos do sentido, o capítulo se divide em duas partes. Na primeira, trabalho especialmente com elementos de vídeo, enfocando o modo como certas articulações e composições - que podem chegar a ordem do poético - são estrategicamente utilizadas pela emissora a fim de estetizar as manifestações que tornarão perceptíveis ao telespectador os valores abstratos que compõe o projeto da marca. E, na segunda parte, trabalharei com mais ênfase sobre elementos de áudio, destacando a atuação de recursos como a música, o jingle, o spot publicitário e o uso de ruídos na conformação da identidade audiovisual da Rede Globo. 


\subsection{Recursos visuais - Por uma imagem positiva e duradoura}

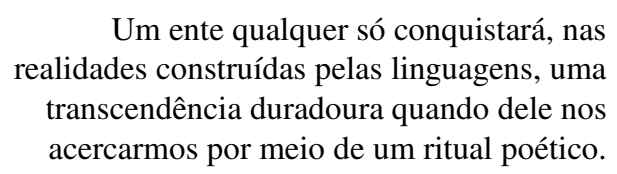

Peñuela Cañizal ${ }^{l 1}$

Em se tratando de estetizar o consumo, o termo "estético" pode ser empregado em duas acepções diferentes. A primeira está ligada a uma perspectiva semio-cultural e a segunda a uma perspectiva mais clássica de filosofia estética. No primeiro caso, de acordo com Semprini, "os estudos culturais e a semiótica utilizam o termo 'estética' para designar a totalidade das manifestações significantes (em especial visuais ou plásticas) de uma entidade discursiva" (2006, p. 189). Assim, a partir do momento em que componentes formais - eidéticos, topológicos, cromáticos etc. - e as próprias construções que resultam da interação entre esses elementos apresentam um caráter coerente, distintivo e persistente no tempo pode-se falar no estabelecimento de uma "estética". Foi com base nessa perspectiva que pude, por exemplo, apontar no primeiro capítulo a existência de um estilo clássico para a marca da Globo - que, como se poderá ver, se mantêm também nas comunicações que manifestam o projeto.

Esse tipo de abordagem, em princípio, pouco se interessa em julgamentos de valor. Desprovida de preconceitos valorativos, seu mérito está no fato de permitir a análise de uma variedade de fenômenos a partir de sua dimensão formal, evidenciando os conteúdos e as estratégias discursivas subjacentes. Todavia, no contexto da reflexão que quero propor nesta primeira parte do segundo capítulo, me aproximarei também da concepção mais tradicional sobre o sentido estético - adaptando-a ao objeto analisado, já que tais manifestações pertencem ao universo do consumo massa.

Isso envolve reconhecer que certas manifestações são criadas a fim de apresentar realmente algum nível de beleza, para que possam suscitar no enunciatário reações como a emoção, a surpresa, o encantamento ou mesmo o sonho. Essas manifestações não têm o

\footnotetext{
${ }^{11}$ PEÑUELA CAÑIZAL, 2012, p. 16.
} 
mesmo escopo da grande arte e, por isso, se configuram como uma estética relativista, contextual e temporária. Entretanto, como bem aponta Semprini, "elas não são menos estéticas porque se deliberou produzi-las assim, porque se deliberou lhes atribuir este caráter e porque se deliberou que este caráter fosse precisamente o que as definem em primeiro lugar" (2006, p. 191).

Desse modo, buscarei mostrar nos próximos tópicos como alguns recursos potencialmente artísticos - como o quadro, o intertexto, a metáfora, a metalinguagem e o anagrama - podem ser aplicados num meio como a televisão, estetizando as comunicações da marca e permitindo às mensagens institucionais maior longevidade no imaginário coletivo em decorrência da sensibilização que promovem no público telespectador, quer dizer, em resultado da experiência estética que proporcionam aos sujeitos - sem perder de vista que na base desses fenômenos estão diversos processos eletrônicos e sintéticos que tanto podem desconstruir como intensificar as propriedades das imagens na tela, contribuindo consideravelmente para o êxito dessa sensibilização e experiência estética.

\subsubsection{Quadro}

O primeiro recurso visual que destaco relaciona-se com a noção de "quadro" desenvolvida por Jacques Aumont em O olho interminável (2004) - mais precisamente no capítulo De um quadro a outro: a borda e a distância. Esse texto dialoga com Pintura e Cinema, de André Bazin (2001), e nele o autor desenvolve os conceitos de "quadroobjeto", "quadro-limite" e "quadro-janela", que estenderei para a televisão.

O primeiro termo, o "quadro-objeto", é definido como "enquadramento material, físico, da tela pintada, a cornija de madeira dourada, o passe-partout ou marie-louse, em suma, o objeto que se chama de moldura e que faz com que haja moldureiros" (AUMONT, 2004, p. 112). No caso da televisão, o quadro-objeto conforma-se justamente nas bordas do aparelho televisivo. Em outros tempos, podia-se falar numa "caixa de TV", mas hoje a coisa é bem diferente, restando apenas uma borda bem fina.

Esses tipos de "moldura" evidenciam uma época, um estágio tecnológico e também certo status social. Se o próprio televisor já foi um artigo de luxo, esse "em torno" ou "quadro-objeto" continua até hoje como um elemento diferencial para os consumidores, pois assim como na pintura, de onde surgiu o termo "quadro", uma televisão "bem emoldurada" - o que atualmente equivale a dizer "tecnológica" e "discreta" - vale mais no mercado. A tendência, inclusive, é que a moldura deixe de existir. Na esteira dos aparelhos 
com imagem em três dimensões, a holografia desponta como destino certo. Desaparecendo a moldura, restam apenas os limites da própria tela ou os limites visuais da imagem. Steven Spielberg nos dá uma amostra disso em Minority Report (2002). Na imagem, o personagem revê cenas gravadas do filho que já morreu. As tradicionais fitas cassete, ou mesmo os mais recentes DVDs, que por décadas fizeram parceria com a televisão, são substituídos por chips futuristas e em vez de imagens enquadradas o que se tem são vivas projeções holográficas.

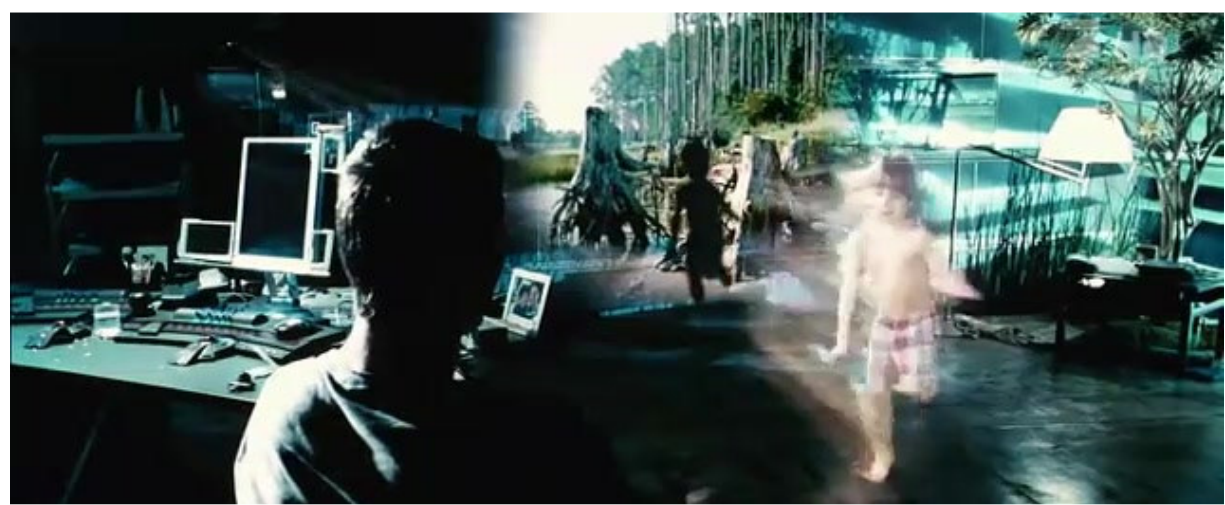

Fig. 13: Cena do filme Minority Report (2002), de Steven Spielberg

Com isso, aparece o conceito de "quadro-limite". Aumont o define assim: "limite físico, esse quadro é também e sobretudo limite visual da imagem; ele regula suas dimensões e proporções; rege também o que chamamos de composição" (2004, p. 13). Se pensarmos na imagem da pintura (quadro), do cinema (tela), ou mesmo da televisão (frame), existe um limite físico que impõe restrições à imagem, que tanto a aperta (zoom in) e dilata (zoom out) como também influencia a disposição das massas visuais - numa busca pela centralidade, que nada mais é do que uma herança renascentista - e, principalmente, demarca o que está dentro e o que está fora do quadro, fixando, assim, os componentes que pertencem à representação e os que pertencem à realidade. De modo que se pode chegar à seguinte formulação semiótica: /interioridade/ vs. /exterioridade/ e /representação/vs. /realidade/.

Mas como as noções de "quadro-objeto" e "quadro-limite" que foram abordadas até aqui podem contribuir na elaboração da mensagem institucional de uma emissora de televisão e, no caso específico da Globo, serem utilizados como recursos visuais que reforcem o projeto da marca? Para responder, tomarei como exemplo o texto (verbal oral, narrado em off) e algumas imagens da primeira vinheta da série A gente se liga em você, exibida em 2011. 
"De repente a gente está lá, frente a frente, torcendo

E aí é você em campo, na pista, na água

Como se cada lance dependesse do seu grito

Você conta com a gente para saber das coisas

E a gente conta tudo

Pensa junto

Discute com os amigos

Se liga no mundo

E encontra as respostas

Tem horas que a gente não consegue segurar

E acaba rindo também

Absolutamente ligado na sua alegria

É tanto tempo junto

Dividindo cada momento

Que a gente até parece fazer parte de uma só família

E assim, de emoção em emoção,

Você acaba enxergando a sua vida dentro da nossa

Através de uma sintonia que, afinal de contas, não tem nada de mágica

Ela é real e existe por um único motivo

A gente se liga em você"

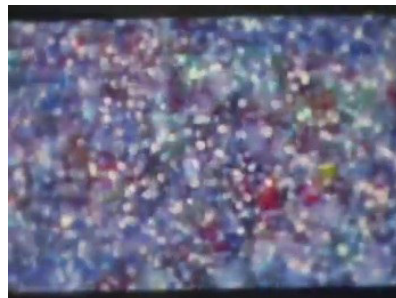

Fig. 14/1

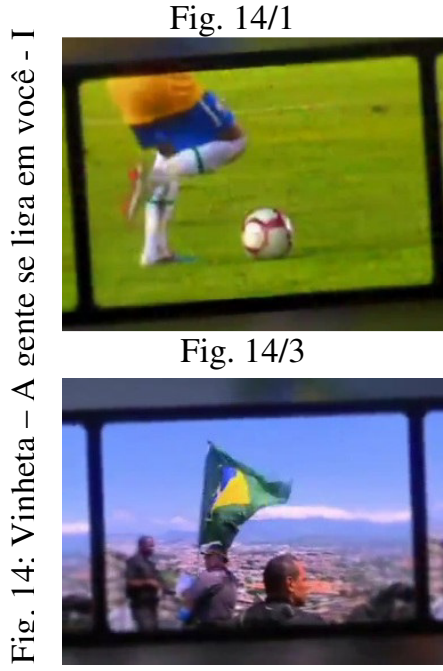

Fig. 14/6

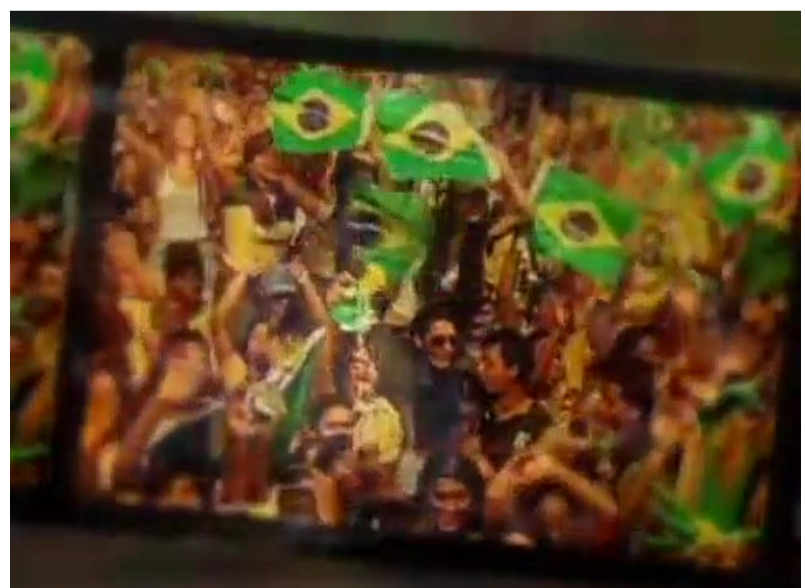

Fig. 14/2

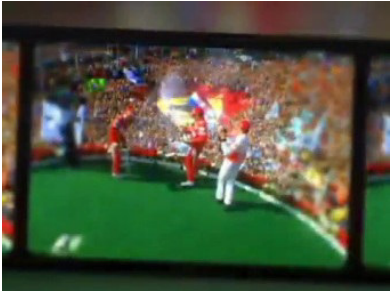

Fig. 14/4

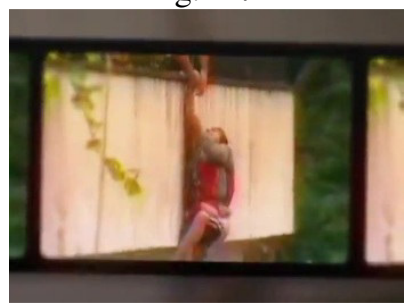

Fig. 14/7

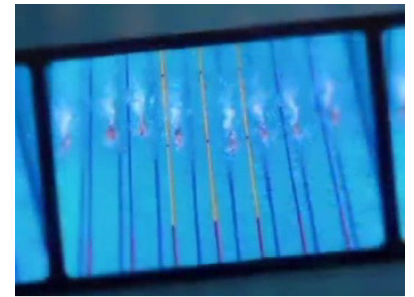

Fig. 14/5

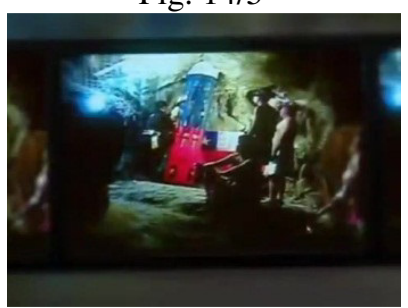

Fig. 14/8 


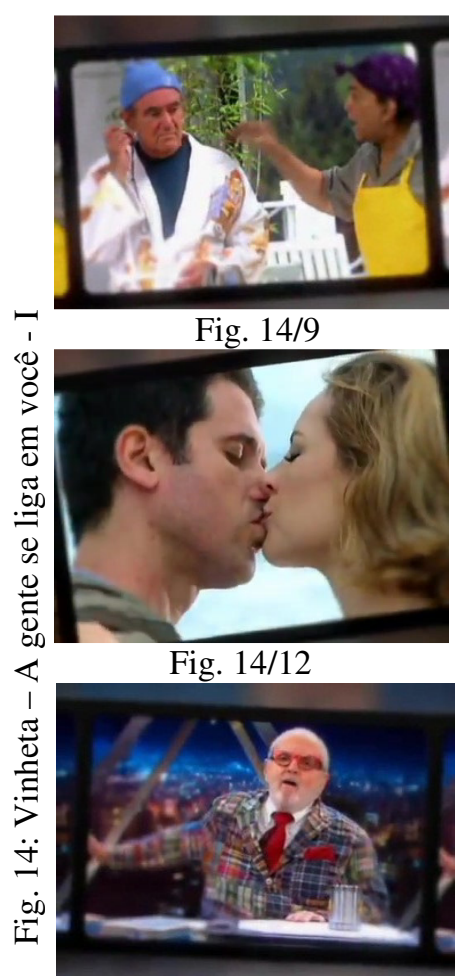

Fig. 14/15

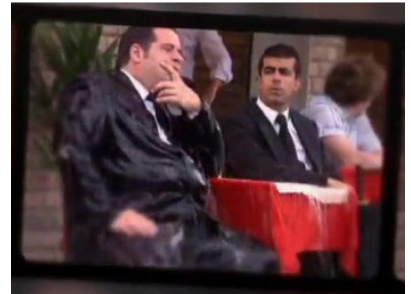

Fig. 14/10

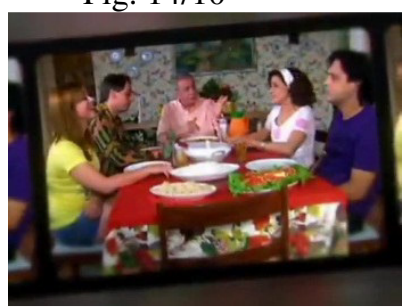

Fig. 14/13

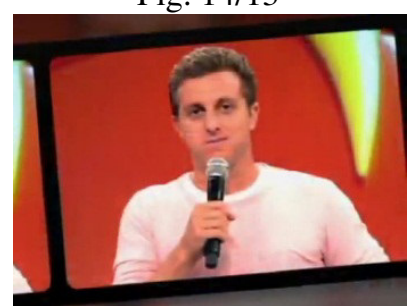

Fig. 14/16

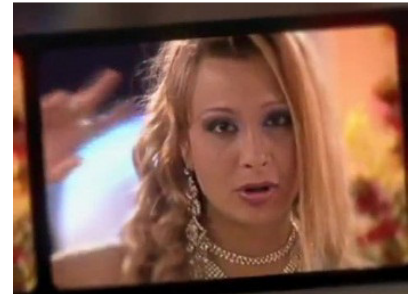

Fig. $14 / 11$

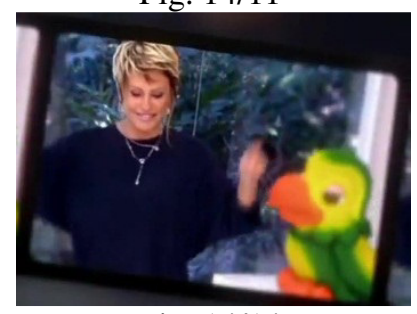

Fig. $14 / 14$

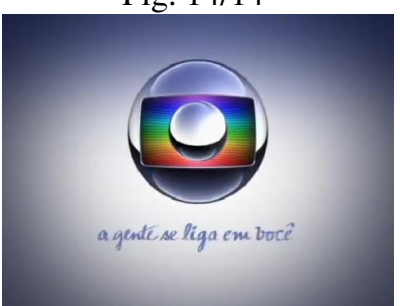

Fig. 14/17

É possível observar que as cenas retratadas estão todas emolduradas. Trata-se do quadro-objeto que citei agora há pouco. As bordas são bem finas - o suficiente para serem apenas notadas -, acompanhando o atual estágio de produção dos aparelhos, que estão cada vez mais discretos. Tal enquadramento, somado à proporção 16:9 das imagens (mais alongadas que no padrão 4:3), nos encaminha para um dos valores predominantes da marca na época em que o vídeo foi produzido, a tecnologia.

Esses aspectos, evidentemente, dizem respeito a um meio específico: a televisão. Outros recursos expressivos como o caráter granuloso da imagem de abertura da peça (fig. 14/1) e as figuras "sintonia" e "liga" presentes no texto verbal reforçam esse sentido, retomando o território de atuação da Globo como empresa e estabelecendo as bases para a função de mediação que constitui a enunciação fundamental da marca. Todavia, o discurso não para por aí.

Apesar dos limites físicos que separam o espaço televisivo e o universo do enunciatário, o objetivo dessa peça é ir além, fazendo sumir as diferenças entre representação e realidade, entre os sujeitos que estão dentro e fora da tela. Enquanto as imagens que figurativizam a televisão são apresentadas com uma borda bem fina, o texto falado busca instaurar a ideia de uma interação não mediada entre as personagens das atrações e o público. Conforme se lê: "de repente a gente está lá, frente a frente" - o que 
sugere um encontro face a face. Isso porque, como mostram alguns dos frames, o olhar das estrelas da Globo está quase sempre apontado para o telespectador, convocando-o a participar, a estar no mesmo espaço.

Com isso, a distância entre os sujeitos vai diminuindo e em pouco tempo o público se esquece da existência de um quadro-objeto ou mesmo de um quadro-limite e de que o encontro se dá somente por sua presença em frente a uma tela. No final, o que se tem é uma completa simbiose - a mesma ideia expressa pela recursividade das figuras "esfera", "retângulo", "esfera" que compõem a marca. Ou como diz o texto da campanha, "você acaba enxergando a sua vida dentro da nossa".

Os limites da borda televisiva então se rompem e esse "estar junto" - expresso em frases como "é tanto tempo junto", "pensa junto", "dividindo cada momento" - parece atingir seu ponto alto na figura da "família", presente tanto em texto - "a gente até parece fazer parte de uma mesma família" - como em imagem (fig. 14/13). Numa visão tradicional, família compreende sujeitos que vivem em comum sob um mesmo teto. Dessa forma, a aproximação que a televisão busca exprimir com a frase evoca o encontro rotineiro, em muitos casos diário, que cada telespectador tem em seu lar com as personagens e as atrações televisivas que mais lhe agradam, figurativizadas nas imagens que a vinheta carrega (fig. 14/3 a fig. 14/16).

A linguagem visual também é responsável por projeções actorias, espaciais e temporais muito significativas. No que diz respeito à actorialização, por exemplo, o narrador do discurso (verbal oral - voz em off) cita diversas vezes a expressão "a gente", estabelecendo um enunciador coletivo, composto por ele próprio e todos os demais profissionais envolvidos na realização dos programas. Esse caráter amplo pode ser depreendido pelos diferentes tipos de imagens apresentadas - eventos ou acontecimentos (fig. 14/3 a fig. 14/8), personagens de atrações (fig. 14/9 a fig. 14/ 13) e apresentadores (fig. 14/4 a fig. 14/16). Quer dizer, aqueles que produzem conteúdos à frente ou atrás das câmeras, dentro ou fora dos estúdios de gravação, interpretando outros ou apresentando a si próprios. Tendo em vista que é o sujeito da enunciação quem atribui voz ao narrador, quer dizer, permite que este narre em seu lugar, quando o vídeo apresenta cada uma dessas imagens o discurso vai além de apenas mostrar aqueles que compõem tal sujeito coletivo. As sequências funcionam como uma espécie de "assinatura", uma imagem autorizada capaz de certificar ao enunciatário de que tais pessoas realmente fazem parte desse "a gente", criando um efeito de verdade muito forte para o discurso. 
Por valorizar cenas específicas, abordando pontualmente alguns personagens e até mesmo focalizando individualmente alguns apresentadores, a vinheta consegue projetar os diversos "eu" que compõe o sujeito coletivo, criando um efeito de proximidade que minimiza o "ele" - empresarial, impessoal e distante - que a imagem da logomarca e a frase "Globo, a gente se liga em você" (verbal-visual e verbal oral - fig. 14/17) projetam ao final da vinheta ao determinar o verdadeiro sujeito da enunciação. Vale perceber neste caso que a imagem não possui qualquer tipo de moldura, saindo do universo da ficção que o "quadro" demarca para o da realidade "não enquadrada". É dessa forma que a vinheta apresenta a Globo como o real sujeito da enunciação, a instância responsável por agregar os diversos tipos de profissionais e dar direcionamento às suas atividades. Reconhecendo o caráter intangível de sua existência como empresa, a emissora se utiliza da imagem de alguns de seus principais programas e profissionais como forma de concretizar-se às vistas do público, transferindo as qualidades e a boa aceitação que possuem para si própria.

$\mathrm{Na}$ outra ponta da comunicação que se estabelece está o enunciatário, projetado no texto verbal como "você". Embora a televisão fale para uma grande quantidade de pessoas o discurso não institui seu enunciatário de modo coletivo, mas como ser individual. Essa projeção está presente também nas imagens e pode ser observada pela oposição "coletivo" vs. "individual" que se estabelece logo nas primeiras sequências do vídeo. No primeiro quadro (fig. 14/1) é possível observar um amontoado de pequenos pontos que, pouco a pouco, revelam um amontoado de pessoas - configurando a imagem de torcedores brasileiros num estádio. Todavia, no segundo quadro (fig. 14/2), a imagem que se forma desfoca as bordas e mantém nítida apenas a parte central, focalizando apenas três indivíduos - um casal e um amigo. De modo que se tem no plano imagético as seguintes relações: /marginal/ vs. /central/; /desfocado/ vs. /nítido/ e /coletivo/ vs. /individual/. Essa abordagem retira o caráter massificado do público e reflete as relações mais íntimas e significativas que um indivíduo - figurativizado no homem que ocupa o centro da imagem e aparece com maior nitidez (fig. 14/2) - pode ter, ou seja, as que giram em torno da "família" e dos "amigos". Exatamente as figuras que ganham destaque no texto verbal.

Deve-se atentar ainda que nas imagens seguintes as ações são retratadas sem que se possa identificar os sujeitos que as executam (fig. 14/3 a 14/5). As perspectivas adotadas ora em plano fechado, ora em plano aberto - são cuidadosamente escolhidas a fim de que cada telespectador possa imaginar a si próprio naquelas cenas. Conforme o texto narrado: "aí é você em campo, na pista, na água". A ideia do discurso, portanto, não é apenas levar 
as imagens da televisão para o telespectador, mas romper o distanciamento que o quadro impõe, fazendo com que o telespectador se veja dentro dessas cenas. Novamente, tem-se aqui a enunciação fundamental da marca e a promessa de intensa interação com a sociedade.

Em termos de projeção espacial, pode-se dizer que essas figuras colocam em evidência eventos que se realizam em diferentes partes do mundo (fig. 14/3 a fig. 14/8) tendo em vista o caráter global que especifica e dá originalidade à promessa de interação que mencionei no parágrafo anterior. Vale dizer que as imagens nesses casos resultam de um tipo particular de representação imagética, que depende da preexistência do objeto representado. Tal captação de imagens cria por si só um forte efeito de referencialidade, dando às cenas a dose necessária de verdade que o discurso precisa para conquistar (fazerquerer) e convencer (fazer-crer) o telespectador - em relação à promessa de interação e a função de mediação que a emissora propõe. De modo que o telespectador possa perceber os eventos como "reais" mesmo e sinta, por isso, vontade de participar - ou, neste caso específico, continue participando, pois o discurso projeta também um "nós", apontando para uma interação já existente entre o enunciatário e o enunciador.

Trata-se, portanto, da manutenção e fortalecimento das relações em curso, já que aquele que recebe a mensagem institucional - divulgada apenas pela televisão - já aceitou em alguma medida o contrato proposto pela emissora. Daí a projeção do "nós" no discurso, em frases como "a gente está lá, frente a frente", "dividindo cada momento" ou "a gente até parece fazer parte de uma só família”. O texto chega até mesmo a explorar as particularidades do contrato em andamento ao dizer "você conta com a gente para saber das coisas e a gente conta tudo". Toda essa argumentação em torno de um contrato que vem se cumprindo conforme as expectativas estabelecidas atribui verdade ao enunciador. De modo que o telespectador poderia concluir que aquele em quem depositou fé e que vem realizando o que prometeu é corretamente digno de continuar recebendo a sua confiança.

As bases desse contrato podem ser melhor visualizadas no modelo que a semiótica fundou acerca da circulação de valores numa narrativa: 


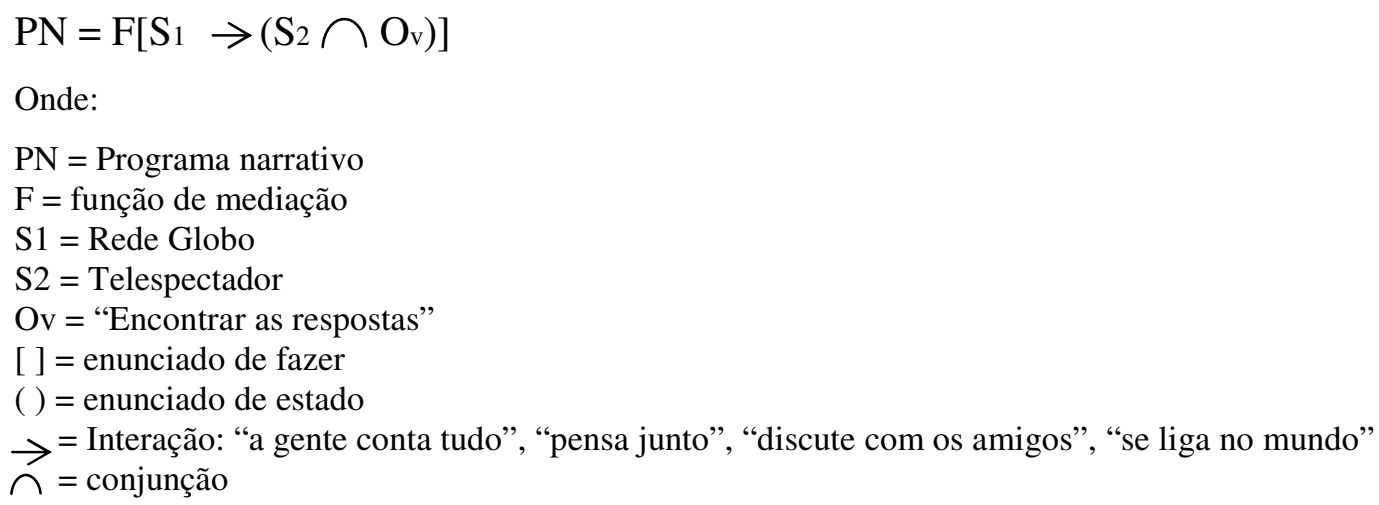

A atuação que o enunciador destaca a respeito de si próprio ou da função de mediação que cumpre, como se pode notar, abarca todo tipo de reflexão, mostrando-se completa: é informativa - "a gente conta tudo" -, analítica - "pensa junto" - e crítica "discute com os amigos". Modaliza o sujeito (fazer-querer, como explicitado anteriormente, e fazer-saber como vimos agora em "a gente conta tudo"), tornando-o competente (fazer-ser - "se liga no mundo") para a ação (poder-fazer e saber-fazer "encontrar as respostas").

Quanto à projeção temporal, as imagens trazem programas que são veiculados em diferentes faixas horárias, com diferentes tipos de conteúdo, visando diferentes públicos manhã (fig. 14/14 - culinária), tarde (fig. 14/16 - generalidades), noite (fig. 14/12 novelas); e madrugada (fig. 14/15 - entrevistas) - com o objetivo de trazer à tona o valor de pluralidade que atravessa a marca por meio da diversidade da programação, quer dizer, programas para todo tipo de público. Essa opção também cria um efeito de totalidade de preenchimento da grade, transmitindo ao telespectador a ideia de que ele pode se valer da função de mediação que a emissora propõe em qualquer horário do dia ou da noite, de acordo com as suas possibilidades e circunstâncias. De modo que jamais ficará excluído do que acontece no mundo por, talvez, poder ter acesso ao meio apenas em horários restritos ou atípicos.

Por fim, a centralidade dos objetos enquadrados - personagens, apresentadores e eventos -, a maneira organizada como são apresentados, seguindo sempre um mesmo padrão, e a qualidade das imagens (sem qualquer tipo de interferência ou ruído) revelam o estilo clássico presente no projeto. 


\begin{tabular}{|c|c|c|c|}
\hline \multirow{4}{*}{\multicolumn{2}{|c|}{$\begin{array}{c}\text { Especificação } \\
\text { Promessa }\end{array}$}} & Temas & Figuras \\
\hline & & Mediação & Emolduração de imagens do mundo natural \\
\hline & & Interação & "é tanto tempo junto"; "pensa junto"; "dividindo cada momento", "família" \\
\hline & & $\begin{array}{l}\text { Nível } \\
\text { Global }\end{array}$ & "se liga no mundo"; eventos nacionais e internacionais(fig. 14/3 a fig. 14/8) \\
\hline 는 & Território & Televisão & $\begin{array}{l}\text { Quadro-objeto; quadro-limite no padrão 16:9; } \\
\text { imagem granulosa (fig. 14/1); "liga"; "sintonia" }\end{array}$ \\
\hline ב & Valores & Tecnologia & Bordas finas; quadro-limite no padrão $16: 9$ \\
\hline & Valores & Pluralidade & $\begin{array}{l}\text { Imagens de uma programação diversificada (fig. 14/3 a fig. 14/16) } \\
\text { Conteúdos: esporte; notícias; humor; novelas, seriados; } \\
\text { culinária; entrevistas; generalidades } \\
\text { Períodos: manhã; tarde; noite; madrugada } \\
\text { Público: homens, mulheres, crianças }\end{array}$ \\
\hline & Valores & $\begin{array}{l}\text { Estilo } \\
\text { clássico }\end{array}$ & $\begin{array}{l}\text { Centralidade dos objetos enquadrados; } \\
\text { estilo delgado das bordas dos aparelhos (fig. } 14 / 3 \text { a fig. 14/17) }\end{array}$ \\
\hline
\end{tabular}

\begin{tabular}{|l|l}
\hline Temporais & $\begin{array}{l}\text { Programas de todas as faixas horárias, visando diferentes públicos: } \\
\text { Manhã (culinária - fig. 14/14); Tarde (generalidades - fig. 14/16) } \\
\text { Noite (novela - fig. 14/12 ); Madrugada (entrevista 14/15) }\end{array}$ \\
\hline \multirow{2}{*}{ Actanciais } & $\begin{array}{l}\text { Eventos nacionais (fig. 14/6) e internacionais (fig. 14/8 - Chile); } \\
\text { "em campo" (fig. 14/3), "na pista" (fig. 14/4), "na água" (fig. 14/5) }\end{array}$ \\
$\begin{array}{l}\text { "A gente" - Enunciador coletivo (fig.14/3 a fig. 14/17) } \\
\text { "Vocên" - Público individualizado (fig. 14/2) } \\
\text { "nós" - enunciatário e enunciador (texto verbal-oral) }\end{array}$
\end{tabular}

Além do quadro-objeto e do quadro-limite, Jacques Aumont conceitua o quadrojanela: "mundo imaginário 'que se afina com os nossos desejos'” (2004, p.114). Se a ideia de janela está atrelada a de uma abertura para que seja possível a passagem do ar e da luz, funcionando mesmo como uma abertura sobre a vista, tem-se aqui também a marcação de uma interioridade e de uma exterioridade. No caso da televisão, não se trata somente de uma abertura sobre a vista, mas especialmente sobre o imaginário. Assim, não é de estranhar a aproximação entre a televisão e o conceito de quadro-janela em um dos jingles da emissora, chamado A Globo 90 é nota 100, quando este diz: "a nossa tela é janela, é espelho do mundo". 
"Mais um verão

Verão vocês em nossa tela

Mais emoção

25 primaveras

Um voo no espaço

À frente do tempo

Revive e renasce

Cada vez mais forte

Toda a esperança em nosso futuro

Não tem pra ninguém

A Globo 90 é nota 100

Globo 90, não tem pra ninguém é nota 100

Levamos à sua casa a nossa alegria

$\mathrm{O}$ abraço mais quente na noite mais fria

Vem com a gente cantar

É hora de comemorar, uoooooooool!
25 primaveras juntos

Juntos com você!

Vamos todos

Nesse voo

Cheio de estrelas

A nossa tela é janela

É espelho do mundo

É sangue novo nas veias da gente

Juventude e amor

É o gosto do povo

Pra você ser feliz num segundo

Não tem pra ninguém

Não tem pra ninguém a Globo 90 é nota 100

Globo 90 não tem pra ninguém é nota 100” (2x)

Locução: Um 90 nota 100 pra você também

(Jingle da campanha A Globo 90 é nota 100)

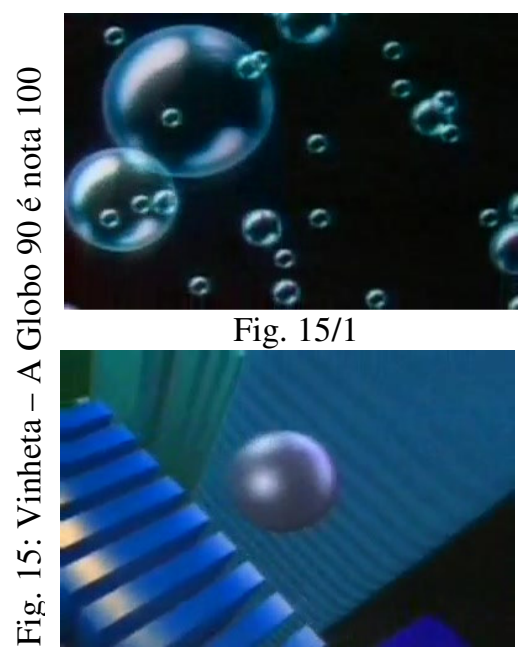

Fig. 15/4

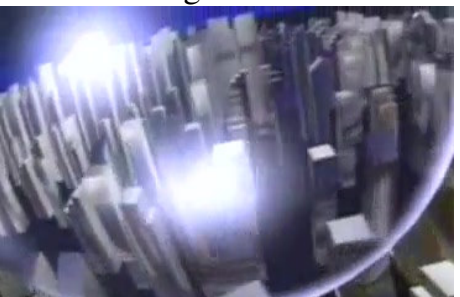

Fig. 15/7

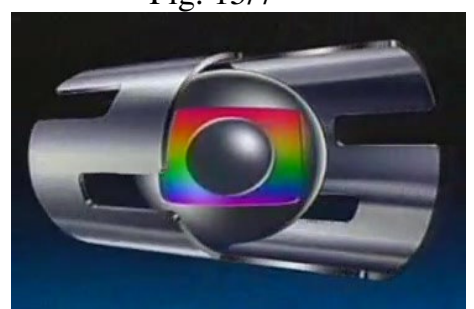

Fig. 15/10

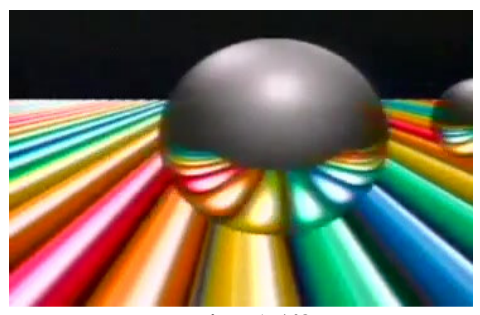

Fig. 15/2

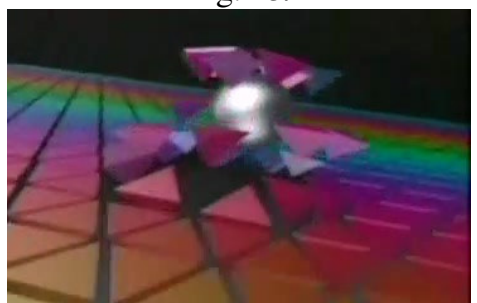

Fig. 15/5

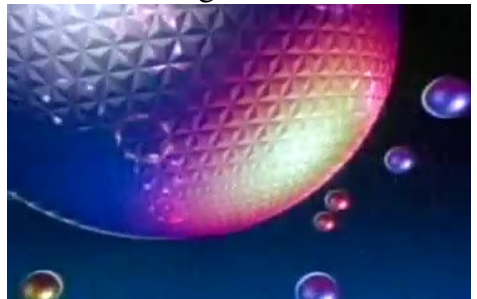

Fig. $15 / 8$

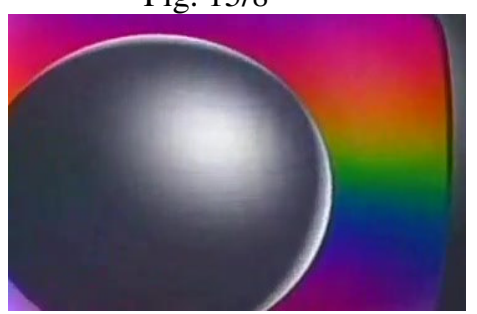

Fig. 15/11

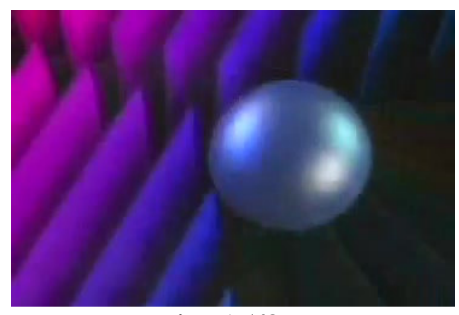

Fig. 15/3

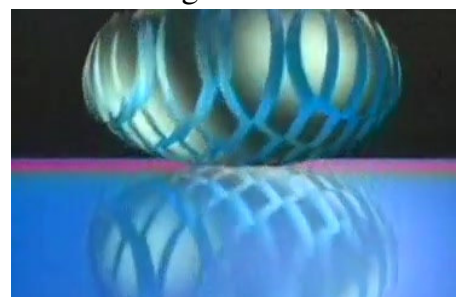

Fig. 15/6

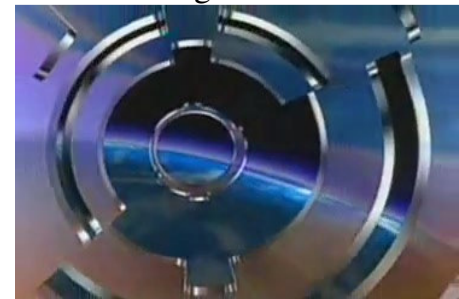

Fig. 15/9

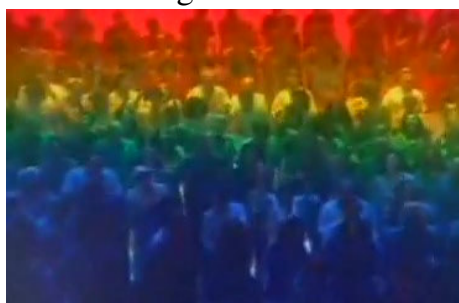

Fig. 15/12 


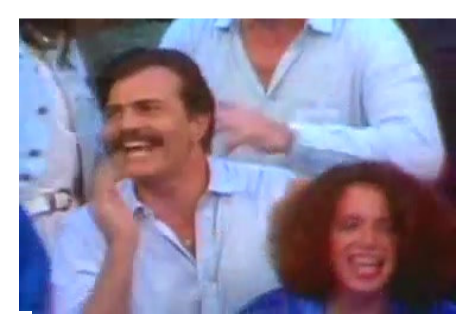

$15 / 13$

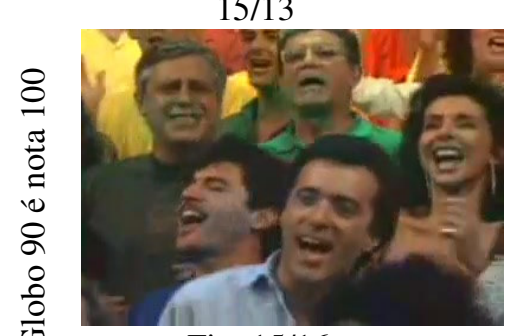

Fig. 15/16

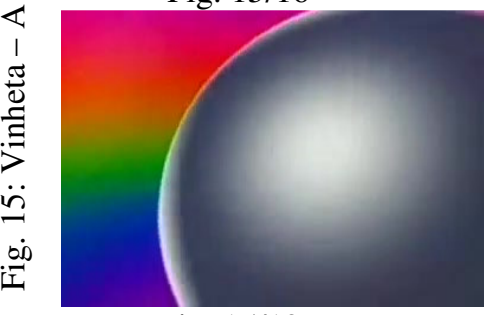

Fig. 15/19

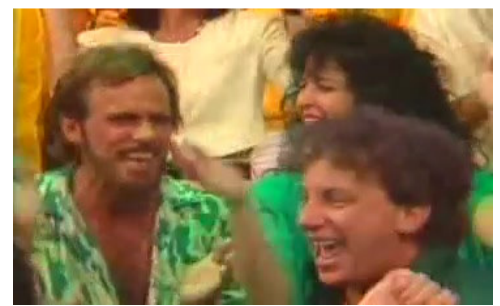

Fig. 15/14

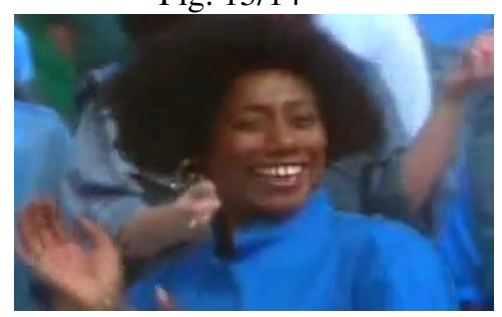

Fig. 15/17

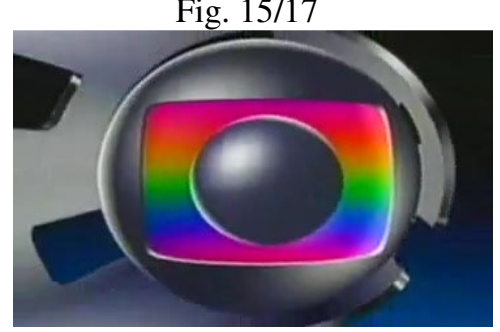

Fig. 15/20

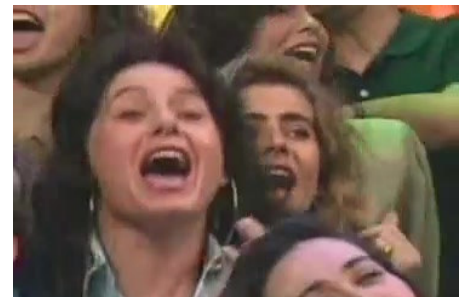

Fig. 15/15

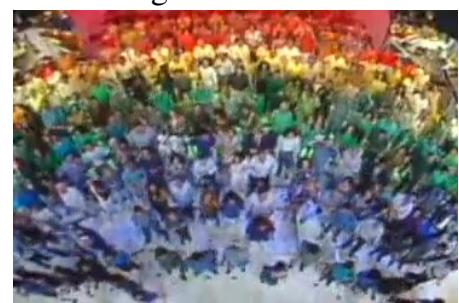

Fig. $15 / 18$

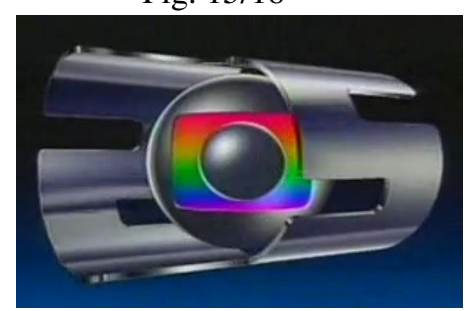

Fig. 15/21

Diferentemente do caso anterior, em cujo enfoque a referencialidade era um pressuposto fundamental para manutenção do contrato entre a emissora e o telespectador fazendo com que as figuras do texto e das imagens se ocupassem de realizar e destacar esse tipo de marcação - nesta vinheta o contrato gira em torno de outros valores, mais especificamente "o mundo imaginário que se afina com os nossos desejos", como definiu Aumont sobre o quadro-janela (2004, p.114).

Por esse motivo, as figuras que se instalam buscam dar concretude mais a elementos do sonho, do imaginário, que do mundo referencial - embora esse tipo de concretização, evidentemente, esteja presente no texto por fazer parte da enunciação fundamental da marca. Isso pode ser comprovado pela própria expressão figurativa "espelho do mundo" que se segue à "nossa tela é janela", expressão que destaquei anteriormente por conter figuras que tendem a valorizar imaginário. De modo que o tratamento figurativo continua visando as relações que se estabelecem entre o enunciador e o enunciatário, mas fazem isso por meio de outro tipo de abordagem ou estratégia, enfocando agora aspectos subjetivos em vez de objetivos. Em termos semióticos, essa mudança de posicionamento poderia ser representada pela oposição "objetividade" $v s$. "subjetividade" ou "realidade" vs. "imaginário". 
A figura mais emblemática nesse sentido parece ser a imagem da Spaceship Earth (fig. 15/8). Deve-se observar nela que, apesar de sua forma esférica e disposição no quadro como um objeto suspenso num fundo infinito, em alusão ao planeta em que vivemos, tal esfera possui uma textura geometrizada, composta por marcações triangulares e sua cor é prateada, emanando valores como tecnologia e futurismo, em vez da referencialidade característica da cor azul. O que ela representa? Trata-se da Espaçonave Terra do Epcot Center, um dos parques do Walt Disney World Resort, na Flórida. Nesse parque há duas áreas distintas, o World Showcase e o Future World. Enquanto o primeiro reúne miniaturas de vários países, o segundo, onde se encontra a Espaçonave Terra, traz atrações que fazem projeções sobre o mundo e as comunidades, explorando tecnologias futuristas. Nela, o público assiste à história da comunicação, do homem e o avanço da tecnologia. Durante a vinheta, o globo de Walt Disney se transforma no globo de Hans Donner. A proposta da Espaçonave Terra se alinha com a proposta da emissora e o intertexto é, sem dúvida, um elogio à magia, beleza e novidade tecnológica que fazem acontecer esses dois mundos imaginários: a Disney e a Rede Globo.

Mas, como se pode ver, essa não é a única imagem que figurativiza o mundo dos sonhos, dos desejos e da imaginação. A estrutura delicada das bolhas de sabão (fig. 15/1), a existência de outros objetos aparentemente densos e mesmo assim flutuantes (fig. 15/2 a fig. 15/4), somados à multiplicidade de cores e formas das imagens (fig. 15/2 a fig. 15/6) também transmitem essas ideias, subvertendo a realidade como somente o sonho e a imaginação podem fazer. Não por acaso, a linguagem que predomina nessa primeira parte do vídeo é a computação gráfica, um tipo de representação feita por procedimentos lógicomatemáticos que simplesmente dispensam a pré-existência dos objetos representados e, consequentemente, a necessidade de exibir qualquer aderência ao real ou conformidade às leis que o regem (BETTETINI, 1999 p. 65).

Esse mágico universo, representado em formas geométricas e de modo bastante econômico - refletindo o estilo clássico presente no projeto da marca - é justamente o universo da televisão, o território em que atua a Rede Globo, pois tais imagens são, na verdade, breves excertos de outras vinhetas institucionais da emissora - como explicitarei mais detalhadamente no próximo tópico. Esse sentido midiático é ainda reforçado em figuras como "tela" ou "janela", presentes no texto verbal, representando o ecrã televisivo.

Por se tratar de uma mensagem que valoriza o trabalho da televisão em relação ao imaginário, a promessa de interação se firma sobre aspectos muito subjetivos também. É 
assim, pois, que se fala no texto verbal de "emoção", "esperança", "alegria" e "juventude" e "amor" - objetos de valor para o público - "o gosto do povo", conforme o discurso - e com os quais o enunciatário pode entrar em conjunção e "ser feliz" se assistir à Globo, conforme se visualiza no programa narrativo a seguir:

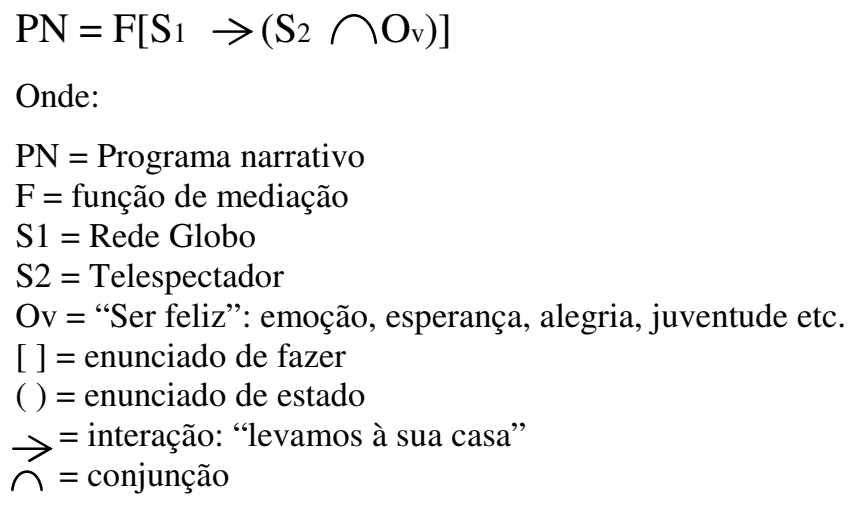

E, novamente, o discurso tenta romper o peculiar distanciamento que perpassa as relações que se desenvolvem apenas através dos meios - como na prática de se assistir à televisão - figurativizando a interação que a emissora busca estabelecer com o telespectador como "o abraço mais quente na noite mais fria", e, posteriormente, convidando-o a se aproximar ainda mais ao dizer "vem com a gente cantar", como se o telespectador pudesse estar também no espaço da televisão. Assim como na vinheta anterior, a proposta não é apenas levar a imagem ao telespectador, mas propor que ele próprio se torne também parte da imagem, participando realmente dos eventos, mesmo que apenas de modo imaginário. Todavia, deve-se observar que neste momento do jingle a imagem já não é mais infográfica, mas captada, criando, portanto, o mesmo efeito de realidade e verdade que explicitei na mensagem institucional anterior - efeitos que modalizam o sujeito para a aceitação do contrato (fazer-crer para fazer-querer). Se o telespectador, em casa, se envolver com o ritmo cativante da música e começar também a "cantar" e "comemorar" é sinal de que a emissora foi bem sucedida em seu propósito, estabelecendo a base contratual que garante sua existência.

Também a especificação da promessa se realiza sobre bases referenciais. O quadro em que isso acontece (fig. 15/9) é um quadro de transição e, por isso, comporta elementos imaginários e referenciais ao mesmo tempo. De modo que ao representar visualmente o "globo terrestre", dando maior concretude ao "mundo" do qual fala o texto verbal, tal imagem busca respeitar suas características aparentes e leis regentes, refletindo tal como 
um "espelho", a visão que se tem dele do espaço - como sua forma arredondada, sua coloração predominantemente azul, seu caráter suspenso e o cenário infinito em que se integra, expresso no vídeo como um fundo preto, às vezes um pouco azulado (fig. 15/1 a fig. 15/9), o qual se apresenta, verdadeiramente, "cheio de estrelas", outra figura do texto verbal que, neste caso, contribui para a ancoragem espacial que se busca estabelecer nesta parte do discurso.

A representação que se faz do universo exprime, sem dúvida, um valor tecnológico - pois remete, mesmo nos casos em que a imagem é infográfica, aos aparatos de ponta necessários para se estar no espaço sideral e observar a imagem. O discurso se aproveita desse sentido que emana naturalmente das imagens e estabelece no texto expressões figurativas que reforçam o caráter tecnológico e futurista da emissora, retratando a experiência de assistir à Globo como "um voo no espaço, à frente do tempo".

Nesta vinheta, o convite feito também se dirige ao telespectador de maneira individual. Embora haja projeções de tipo coletivo como "verão vocês" e "vamos todos", elas são apresentadas, respectivamente, apenas na parte inicial e final do discurso, reconhecendo a pluralidade do público da televisão. Esse valor plural está presente também na figura "povo", utilizada para abordar a necessidade que a televisão tem como meio em prover conteúdos que agradem a todos - "o gosto do povo", conforme a expressão. De modo que em todo o restante do discurso encontram-se projeções como "à sua casa”, "juntos com você", "para você ser feliz".

Quanto ao enunciador, este é, por outro lado, sempre projetado de maneira coletiva. Nesse sentido, vale lembrar que se trata da comemoração dos 25 anos da emissora, conforme projeções temporais como "verão" e, mais especificamente "25 primaveras", denotando a passagem do tempo, o "reviver" e "renascer" ao se completar mais um ano de vida. Evidentemente, uma data festiva. "É hora de comemorar", como diz o texto verbal. E, por isso, é o aniversariante, quer dizer, a Globo como empresa, como agente aglutinador de talentos, que recebe o total destaque. Daí expressões que evocam o "nós" como "nossa tela", "levamos", "nossa alegria", "vem com a gente" ou, simplesmente, "a Globo". Em termos visuais, pode-se notar que as imagens de abertura e encerramento do vídeo, que contêm diversos artistas juntos, são feitas em plano aberto, sem que se possa reconhecer a fisionomia de cada um deles. E sobre tais estão as cores da televisão - azul, verde e vermelho (fig. $15 / 12$ e fig. 15/18). De maneira que os recursos se organizam da seguinte forma neste caso: /plano aberto/ vs. /plano fechado/ e /coletivo/ vs. /individual/. 
Mesmo quando o discurso fala sobre as "estrelas" da emissora, a forma plural presente no texto verbal diminui a ênfase que cada uma delas pode ter quanto ao talento individual e reforça o caráter coletivo da abordagem e, consequentemente, das produções colocando em evidência aquela que gerencia tudo isso, a Rede Globo. Nas imagens, isso se confirma pelo fato de que os artistas não são tomados exatamente em planos fechados, mas numa espécie de plano médio, que apesar de focalizar regiões específicas, como a do rosto em alguns casos, o faz ainda com certo distanciamento ${ }^{12}$. Além disso, diferentemente do que ocorre na vinheta anterior, os artistas nunca aparecem sozinhos nas cenas. Ao seu lado e ao fundo estão muitos outros - uns com mais, outros com menos brilho (fig. 15/13 a fig. 15/17). E, logo em seguida, aparece a logomarca da emissora (fig. 15/19 a fig. 15/21). O sentido que emerge dessa construção visual é, portanto, o mesmo da primeira vinheta: transmitir certa dose de pessoalidade e proximidade a uma entidade a princípio tão impessoal e distante como é uma empresa de televisão ou outra qualquer.

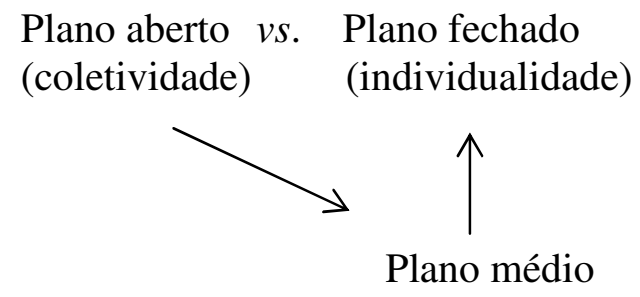

\begin{abstract}
Visto que a expressão visual homologase a oposições de conteúdo, tem-se a seguinte relação neste caso: /plano aberto/vs. /plano fechado/ e /coletividade/vs. /individualidade/. Quanto mais próximo do plano aberto, menor é a ênfase sobre o indivíduo. E quanto mais próximo do plano fechado, maior é o destaque. Uma "estrela", tomada no pleno sentido de sua individualidade, estaria, desse modo, em plano fechado e não em plano médio, como se vê nas figuras
\end{abstract} (fig. 15/13 a fig. 15/17).

\footnotetext{
${ }^{12}$ Em vista da multiplicidade de tipologias existentes - com variados graus de especificidade - em se tratando de planos de filmagem, estabeleci os parâmetros citados por aproximação, e com o intuito único de ilustrar as diferenças mais evidentes - e, portanto, mais extremas - que a oposição "coletivo" vs. "individual" poderia suscitar na vinheta em termos de enquadramento. De modo que não há aqui qualquer pretensão de exaustividade ou rigor.
} 


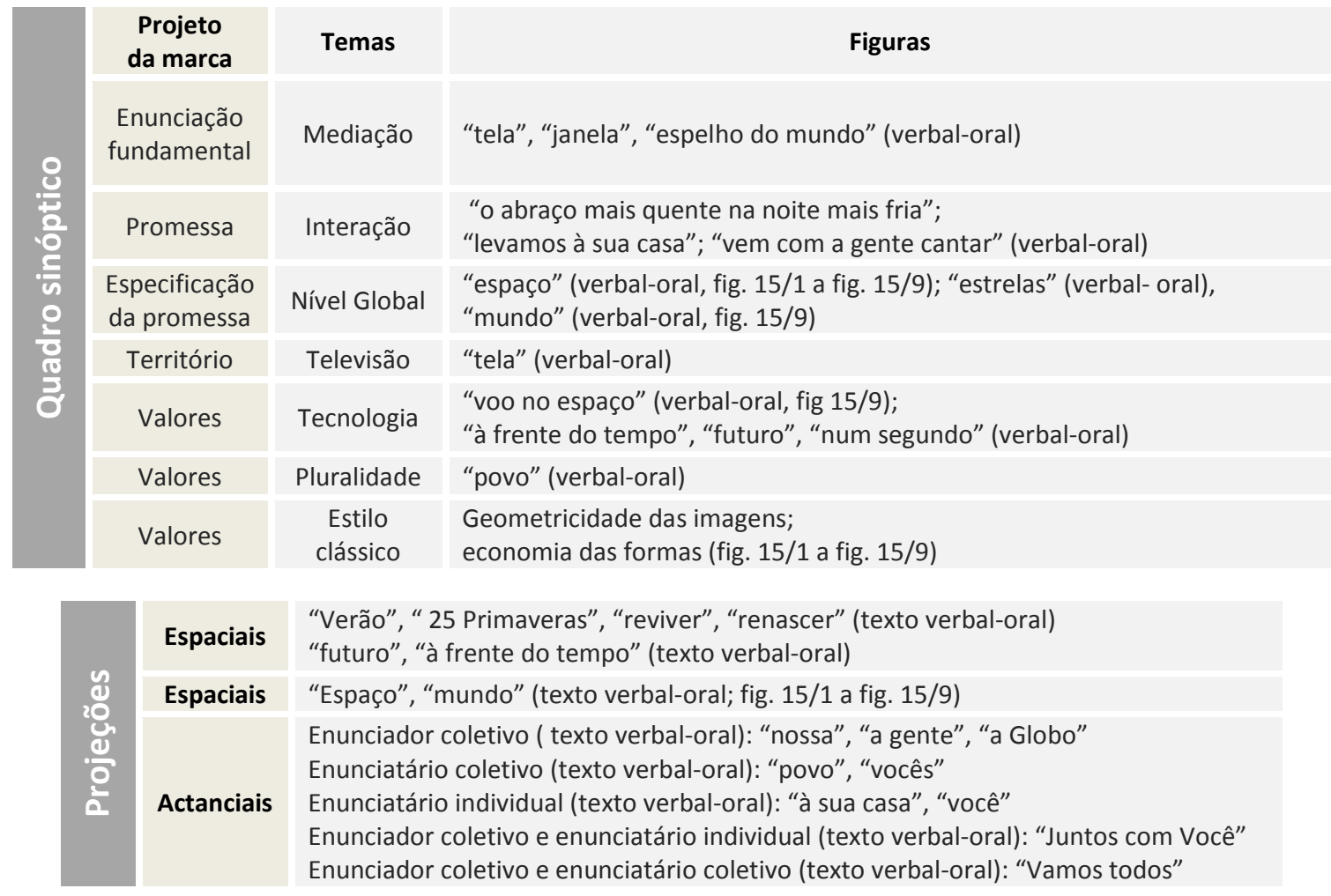

Todas as explorações de sentido abordadas até aqui retomam o conceito criado por Hans Donner. Isso acontece não apenas quanto aos elementos que constituem o projeto da marca, conforme apresentei no primeiro capítulo, mas também pelo fato de que a própria logomarca da Globo consegue articular numa mesma imagem as três noções de quadro propostas por Jacques Aumont. Tal como foi pensada, ela transmite realmente a ideia da televisão como uma janela para o mundo. Mas o desenho também permite enxergar a televisão como uma moldura para o mundo - quer dizer, um quadro-objeto - quando se visualiza o quadrado e o círculo exterior. Ou mesmo como uma tela limite em que, bem no centro, se pintou o mundo - se o foco estiver sobre o quadrado e o círculo interior.

Essa multiplicação de quadros na marca assume poeticamente as características de uma perspectiva em abismo, conseguida pela repetição ou desdobramento de certos elementos formais, que nos trazem imagens dentro de imagens, colocando em diálogo diferentes motivos - com seus distintos significados. Tendo em vista que a logo é atualmente o elemento central das mensagens institucionais, tal recurso expressivo permite a exploração de um complexo percurso de leitura que vai aos poucos e com diferentes ênfases se revelando em cada vinheta da rede, como tentei evidenciar nos objetos trabalhados. 


\subsubsection{Intertexto}

A propósito da vinheta “A Globo 90 é nota 100”, utilizada no item anterior para o desenvolvimento de algumas análises, buscarei destacar outro recurso bastante recorrente nas comunicações da Globo: o intertexto. Segundo Greimas e Courtés, o fenômeno da intertextualidade implica "a existência de semióticas autônomas, no interior das quais se sucedem processos de construção, de reprodução ou de transformação de modelos que podem se revelar mais ou menos explícitas" (1983, p. 242). Esses diferentes graus resultam do modo como o conjunto significante de uma dada semiótica-objeto é utilizado no interior ou na composição de outra semiótica-objeto. De modo que o intertexto resulta sempre das correlações formais que se estabelecem entre duas ou mais semióticas-objeto.

O valor poético que emana em produções que acolhem esse tipo de estratégia discursiva está na polissemia resultante do encontro entre diferentes sistemas de representação e significação. Quanto mais inusitada for a relação que se propõe entre eles, mais instigante se torna o novo sintagma. Na televisão, muitas são as possibilidades de provocar ou incitar o espectador a uma abertura de sentido e de interpretação a partir da utilização do recurso mencionado, o intertexto. Assim, tomando como exemplo a vinheta já citada, buscarei ilustrar duas dessas formas - visto já ter abordado a inserção de figuras ao tratar da referência que se faz à Espaçonave Terra do Epcot Center no tópico anterior.

A primeira forma que destaco então é a montagem visual. É possível observar nas imagens dos frames selecionados três momentos distintos: o primeiro deles compreende a reiteração de formas geométricas, especialmente esféricas (fig. 15/1 a fig. 15/8). O segundo situa-se como uma transição por meio da logomarca comemorativa dos 25 anos da emissora (fig. 15/9 a fig. 15/11). E o terceiro, na parte final, coloca em evidência o rol de artistas que fazem a televisão (fig. 15/12 a fig. 15/18).

Identificados os três momentos, quero chamar a atenção para a estética e a sequencialidade das imagens que compõe o primeiro deles. A prática da montagem, como se sabe, compreende justamente a seleção e agrupamento de planos numa certa ordem tendo em consideração aspectos como a composição visual de cada quadro, por motivo de continuidade, bem como a duração de cada um desses segmentos e também o espaço de tempo entre eles. Da articulação desses aspectos pode resultar tanto uma função narrativa orientada por uma noção de causalidade e/ou temporalidade diegéticas -, como uma função expressiva - orientada por princípios estéticos. Dessas duas posturas podem emergir sentidos denotados e conotados. 
No primeiro caso, é possível perceber que a vinheta obedece a um ordenamento temporal quanto aos segmentos que dispõe na tela. Tal vídeo foi ao ar no fim de 1989 e comemorava o $25^{\circ}$ aniversário que a Globo completaria no ano seguinte. De modo que a primeira metade da mensagem é produzida por meio da justaposição de trechos de diferentes vinhetas institucionais - a partir da seleção e articulação de planos-chave. São, nesta ordem, videografismos dos anos de 1977 (bolhas), 1980 (tubos coloridos), 1983 (abre-alas), 1984 (cidade futurista), 1987 (triângulos), 1988-89 (globo multifacetado e cidade), e 1989 (globo prateado). Todos fazem parte da "Era" Hans Donner e, por isso, apesar da distância temporal que mantêm entre si, conservam os mesmos princípios estéticos, quer dizer, o mesmo estilo clássico presente na logomarca que ele criou para a Globo em 1975 - cujo projeto, portanto, também comemora vida longa.

Visto que era esse projeto o que traduzia os ideais da marca na época em que foi produzido o vídeo, o discurso aciona vinhetas que se limitam a contar a história da Globo a partir da existência da logomarca criada por Hans Donner, deixando para trás os dez primeiros anos da rede. Tal encadeamento de unidades imagéticas, ou intertextos, nos revela um percurso ou trajetória identitária que metonimicamente utiliza elementos representativos da logomarca - em geral, uma esfera - presentes em todos os trechos, para falar da emissora. De modo que as características plásticas desses breves excertos, como a manutenção das cores, dos traços finos, do design geométrico e limpo apontam para reiterações formais que não apenas dão a eles um sentido de unidade, permitindo enxergálos como um único segmento apesar de se originarem de diferentes semióticas-objeto, mas, sobretudo, revelam um discurso que se mantém absolutamente coerente ao longo dos anos, a despeito das diferentes nuanças que possam ter sido exploradas em cada um dos vídeos. Essa certeza, deflagrada pelos elementos formais, nos permitem compreender, então, que a proposta da primeira parte da vinheta é conceber uma narrativa ou "história de vida" que se constituiu justamente na somatória de tais comunicações da marca ou, em outros termos, na somatória dos valores que tais produções engendraram.

Apenas para contextualizar, vale dizer que: o segundo momento do vídeo, protagonizado pela aparição da logomarca comemorativa dos 25 anos da emissora, revelase como um elemento de transição - por meio do qual, num movimento de zoom in, entraremos na metáfora que se estabelece na terceira e última parte do vídeo, e da qual sairemos num lance de zoom out. Nela, o elemento de contiguidade é a cor, ou melhor, o colorido da logomarca que se estende também em faixas ao se fazer o agrupamento dos 
artistas. O elemento do qual se parte é a logomarca e o elemento ao qual se chega são as pessoas. No vídeo, a Globo como emissora de televisão é representada, metonimicamente, pela logomarca. E esta, do mesmo modo, por pessoas. A metáfora que emerge - a Globo como o conjunto de seus artistas - propõe então por desfecho o componente humano como a essência ou força motriz que faz a máquina girar e ter história pra contar.

Voltando à intertextualidade, a segunda forma de promover aberturas de sentido que quero destacar é a montagem sonora. Assim como no âmbito visual, a disposição orientada dos sons fomenta significados que não estão presentes, por assim dizer, em cada segmento isolado. Mas somente vêm à tona pela articulação entre eles. Nesta vinheta, a mensagem, especialmente por se configurar como um jingle, possui musicalidade própria. Porém, seus arranjos iniciais e finais se mesclam intertextualmente, numa espécie de aglutinação, aos da trilha de "Um novo tempo" - composição de Marcos Valle, Paulo Sérgio Valle e Nelson Motta - utilizada como mensagem padrão da emissora para celebrar todo novo ano.

A disposição emblemática que tais sonoridades ocupam - a música de "Um novo tempo" nas pontas e o jingle “A Globo 90 é nota 100” no meio - nos encaminham diretamente para oposições como /englobante/ vs. /englobado/ e /futuro/ vs. /passado/, pois, de fato, o futuro sempre contém o passado, sendo resultante dele e do que foi nele gestado. Com isso, a Globo atribuiu interdependência e equivalência em termos de importância a esses dois momentos históricos, colocando-se, talvez, como Jano, o deus romano que tinha duas faces - uma voltada para a frente, mirando o futuro, e outra para trás, contemplando o passado - e do qual derivam as comemorações de janeiro, dos ciclos que se encerram e dos ciclos se que iniciam. Os mesmos ciclos que a vinheta celebra. O que mais uma vez revela um verdadeiro exercício sobre a identidade expressa no projeto da marca criada por Hans Donner, pois, de acordo com Semprini, "olhar para o futuro não significa obviamente renegar o passado. Destacar a dimensão dinâmica e evolutiva da marca permite, igualmente, lembrar que uma marca se inscreve sempre no tempo e, principalmente, em seu passado" (2006, p. 118).

\subsubsection{Metáfora}

Como cheguei a esboçar no item anterior acerca do segundo e terceiro momentos da vinheta "A Globo 90 é nota 100", a televisão também se utiliza com frequência de recursos metafóricos para compor suas mensagens institucionais. Em termos verbais, 
sempre que se emprega uma palavra em sentido diferente do próprio o resultado é uma metáfora. Nas próximas páginas tentarei abordar como é possível expandir esse princípio para os domínios do audiovisual. A vinheta que me utilizarei especialmente para esse fim acompanha o slogan Globo e você, tudo a ver ${ }^{13}$.

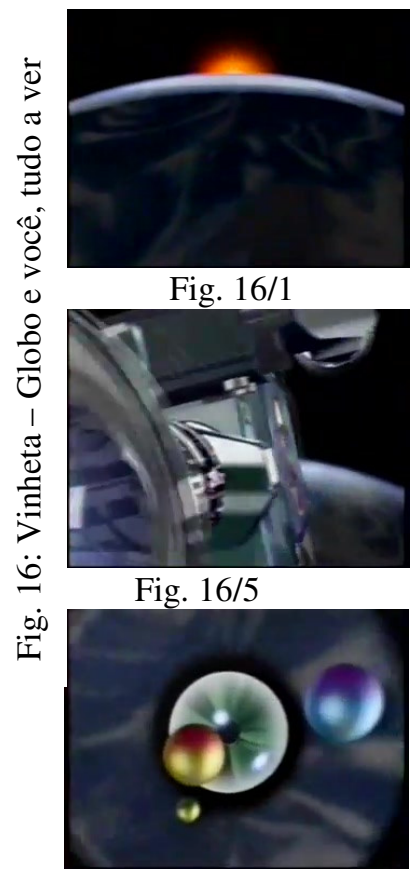

Fig. 16/9

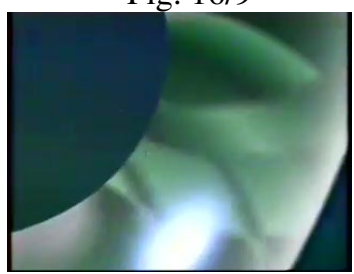

Fig. 16/13

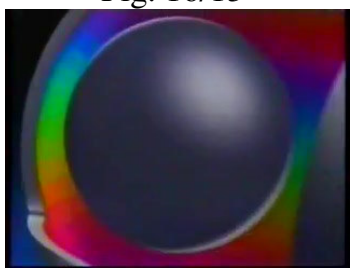

Fig. 16/17

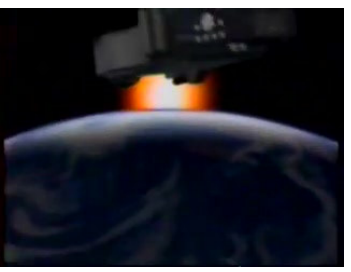

Fig. 16/2

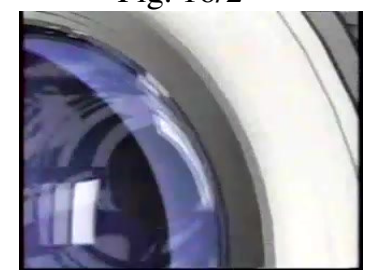

Fig. 16/6

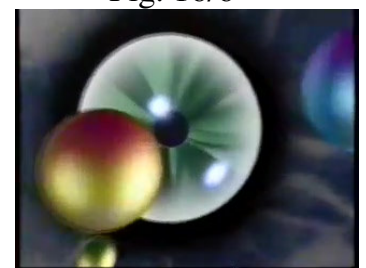

Fig. $16 / 10$

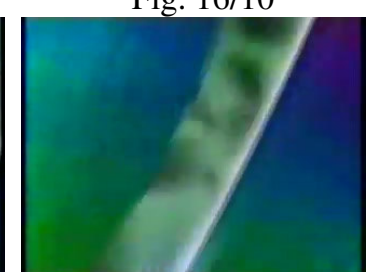

Fig. 16/14

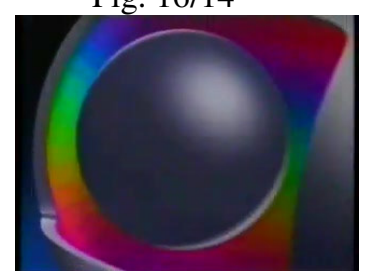

Fig. 16/18

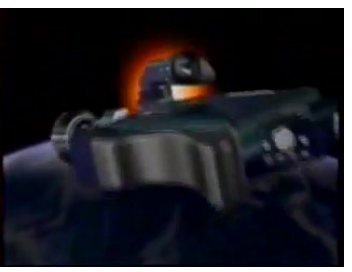

Fig. 16/3

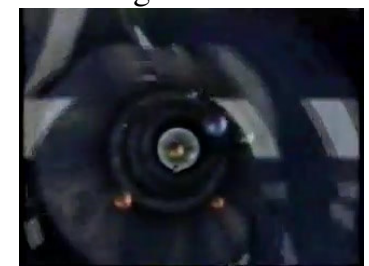

Fig. 16/7

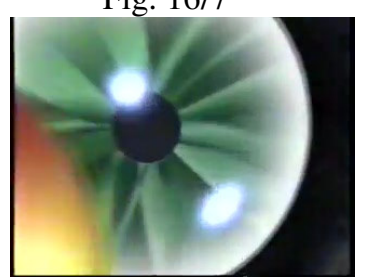

Fig. 16/11

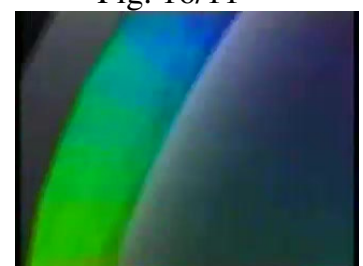

Fig. 16/15

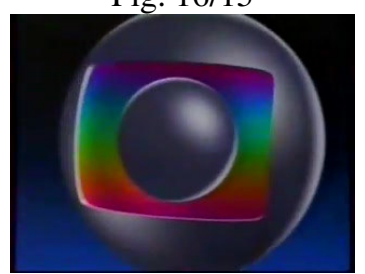

Fig. 16/19

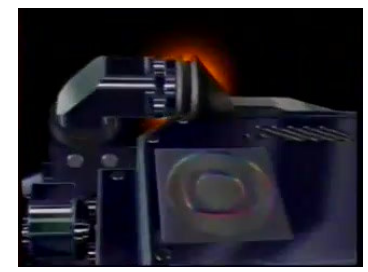

Fig. 16/4

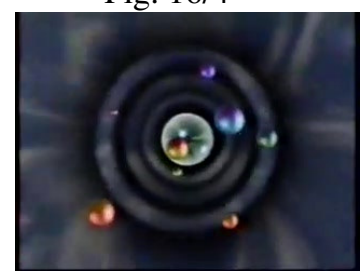

Fig. 16/8

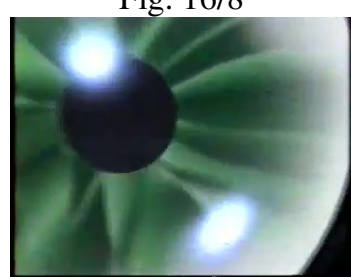

Fig. 16/12

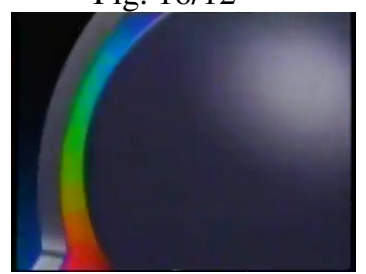

Fig. 16/16

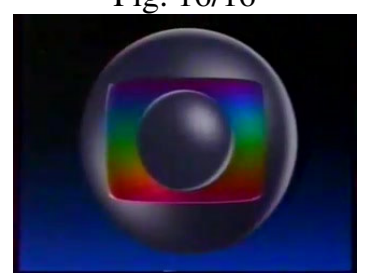

Fig. 16/20

Nessa vinheta duas analogias são estabelecidas. A primeira se dá entre a lente de uma câmera de filmagem e o olho humano; a segunda, entre o olho humano e a logomarca da Rede Globo. E como isso acontece? Na televisão, quando uma imagem se metamorfoseia em outra são geralmente os formantes visuais - eidéticos, topológicos,

\footnotetext{
${ }^{13}$ http://www.youtube.com/watch?v=TmvkmBOLrv0
} 
cromáticos - que manifestam a ligação entre as figuras, garantindo a continuidade da ideia que se quer propor, a metáfora.

Depois disso, o reconhecimento da imagem, de suas funções e atributos, fica por conta do repertório do telespectador. E como a televisão do sistema broadcasting quer atingir a todos, suas metáforas buscam ser de fácil compreensão. Veja a simplicidade da ideia por trás das duas metáforas citadas:

\begin{tabular}{|c|c|c|c|}
\hline $\begin{array}{c}\text { LENTE } \\
\text { (termo de partida) }\end{array}$ & $\begin{array}{c}\text { OLHO HUMANO } \\
\text { (termo de chegada) }\end{array}$ & $\begin{array}{c}\text { OLHO HUMANO } \\
\text { (termo de partida) }\end{array}$ & $\begin{array}{c}\text { OLHO GLOBO } \\
\text { (termo de chegada) }\end{array}$ \\
\hline $\begin{array}{c}\text { Circularidade/Visão } \\
\text { (termos intermediários) }\end{array}$ & $\begin{array}{c}\text { Circularidade/Visão } \\
\text { (termos intermediários) }\end{array}$ \\
\hline
\end{tabular}

Os termos intermediários entre o elemento do qual se parte e o elemento ao qual se chega numa metáfora, como no caso das transformações visuais na vinheta, é o que se chama de classe limite. Por mais diferentes que sejam dois objetos é sempre possível encontrar uma classe limite em que estes figurem juntos, uma intersecção, uma porção comum ao mosaico de suas partes. E é justamente essa parte comum a responsável pela existência da metáfora.

Quanto à primeira analogia, nessa conhecida comparação entre o olho humano e a objetiva de uma câmera, persiste em termos de função a visão e em termos imagéticos a circularidade das formas. Desse modo, estabelece-se com facilidade o convite ao telespectador para que ele veja o mundo através das lentes da Globo - conforme o slogan "Globo e você, tudo a ver". É essa ideia que se busca com a simulação do universo no início da vinheta, por meio da cor preta que estabelece um fundo infinito tal como o do cosmo; a própria figura do planeta Terra, com sua coloração predominantemente azul, forma arredondada e caráter suspenso; e também a existência de outras esferas que em tal cenário simulam planetas em órbita (fig. 16/1, fig. 16/2, fig. 16/7 e fig. 16/8).

Em relação a tais aspectos, cabem algumas considerações. A primeira é a própria promessa de interação que se expressa na frase "Globo e você", responsável por projetar um enunciador coletivo, a Globo como empresa, e um enunciatário individual, "você". Em seguida, está o âmbito global que especifica a promessa, conforme as imagens destacadas no parágrafo anterior. Mas, além disso, a figura do "cosmo" associada à palavra "tudo" também transmite uma ideia acerca da pluralidade ou grande quantidade de conteúdos a que se pode ter acesso através das lentes da Globo, sendo este sentido um dos valores que a 
comunicação da marca exprime. Outro é o estilo clássico, pois poucos sistemas são tão harmônicos e organizados quanto o dos planetas em órbita, conforme representado nas imagens. E, por fim, a figura de uma câmera de filmagem flutuante no espaço deixa no ar o know-how tecnológico necessário para se fazer captações em lugares de difícil acesso. Com isso, o vídeo explicita o território de atuação da Globo e demonstra que a televisão é capaz de chegar a lugares em que o telespectador dificilmente conseguiria - projetando no cosmo o espaço do "lá", distante e inacessível - motivo pelo qual a emissora se presta a ser os olhos do telespectador, a partir da qual se podem ver todas as coisas. E, diga-se de passagem, não é preciso chegar a casos tão extremos como o que a vinheta apresenta, já que certos eventos que ocorrem até bem perto de nós, em nosso bairro ou cidade, são às vezes mais "bem vistos" pela televisão do que pelo sujeito que se encontra presencialmente neles.

$\mathrm{Na}$ segunda parte, em relação à metáfora, permanecem os mesmos termos intermediários, a circularidade e a visão, mas o enfoque é diferente em razão da figura da qual se parte e a figura a qual se chega e se constrói a metáfora - o olho humano e a logomarca da Globo. O elemento de ligação entre as imagens fica por conta do cromatismo, do verde especificamente, que faz a transição entre a íris humana e o fundo da logomarca da emissora. Com isso, qual o sentido da mensagem? Levar às últimas consequências a função de mediação, que é a enunciação fundamental da marca.

Para entender, basta lembrar que a Globo aparece na primeira parte da vinheta como instrumento de captação de imagem. A objetiva da câmera substitui, por assim dizer, o instrumento visual pelo qual o ser humano capta o mundo à sua volta, o olho. Já na segunda metáfora esse olho humano tem por objetivo criar uma noção de sujeito, como uma metonímia. Dessa forma, nesse segundo momento, a Rede Globo não aparece mais como um instrumento apenas, mas como um sujeito enunciador no lugar do sujeito empírico. Em termos narrativos, a metáfora que se desdobra pode ser descrita semioticamente da seguinte maneira:

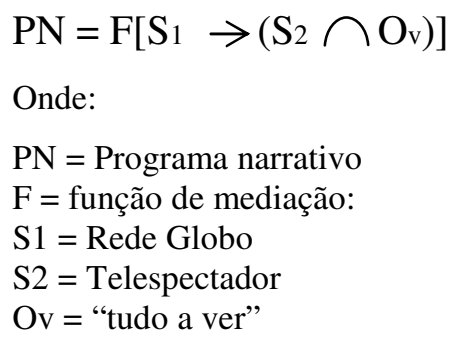


[ ] = enunciado de fazer

()$=$ enunciado de estado

$\rightarrow$ = interação: "ser os olhos do telespectador"

$\vec{\cap}=$ conjunção

A proposição do sujeito enunciador no lugar do sujeito empírico poderia representar uma perda para o telespectador, pois à medida que se enquadra um conteúdo, como faz a televisão, evidentemente se estabelece um ponto de vista, dando apenas um acesso parcial sobre os acontecimentos. Todavia, a Globo assegura que não. $\mathrm{O}$ distanciamento e a perspectiva com a qual as imagens são tomadas (fig. 16/1 e 16/2), somados à própria figura que se busca retratar, que é o "mundo", e a expressão "tudo a ver" funcionam no discurso como argumentos que minimizam o caráter limitado que sempre acompanha uma escolha desse tipo, de representação midiática.

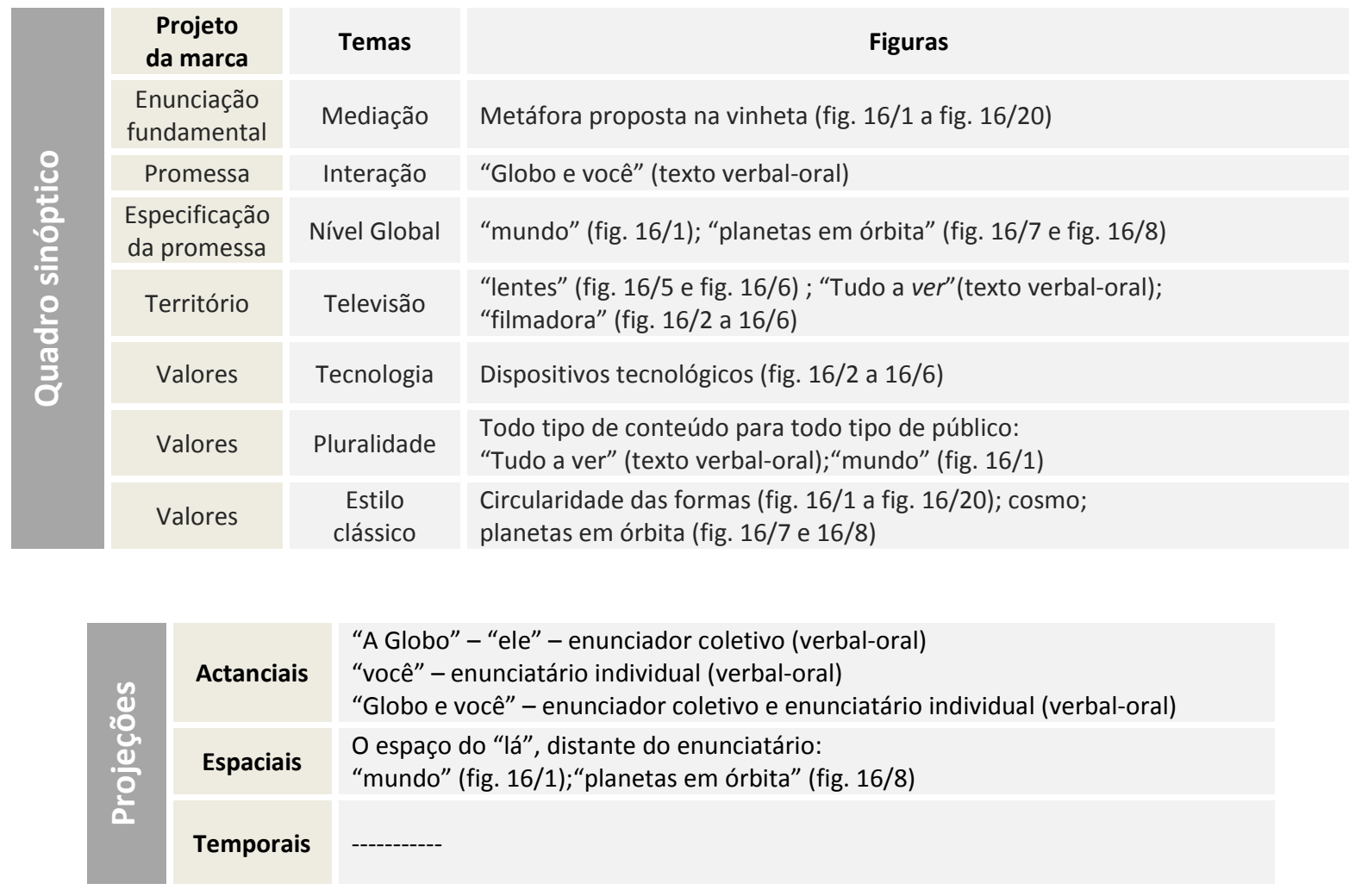

Observa-se dessa maneira que embora as metáforas se estabeleçam por conta de semelhanças entre as funções e as propriedades de dois ou mais objetos colocados em relação, numa produção audiovisual a busca por correspondências deve extrapolar as funções e propriedades que tais objetos possuem no mundo natural - que são social e culturalmente conhecidas, fruto do repertório do sujeito -, e passar a reconhecer também as 
semelhanças, rimas e correspondências visuais que a imagem oferece, numa posição de abertura para significados inusitados que possam ser sugeridos numa produção.

\subsubsection{Metalinguagem}

A função metalinguística, conforme Jakobson, é uma função centrada no código. Segundo ele, "uma distinção foi feita, na Lógica moderna, entre dois níveis de linguagem, a 'linguagem-objeto', que fala de objetos, e a 'metalinguagem', que fala da linguagem" (2007, p. 127). Estendendo o conceito para o campo do audiovisual, pessoas, produtos e histórias desde sempre compuseram a "linguagem-objeto" da televisão. Coisas sobre as quais a televisão fala. No entanto, assim como outros sistemas semióticos - a língua, a dança, a pintura etc. - podem se voltar para suas estruturas, modos de articulação e funcionamento, a televisão vez por outra também se volta para seu próprio código, colocando em evidência o modo de inscrição da imagem televisiva.

Para se ter uma ideia, esse recurso já havia aparecido na primeira vinheta analisada - "A gente se liga em você" (fig. 14/1) - mas irei abordá-lo com mais destaque com base numa vinheta de 1985. O slogan da Globo nessa época era "O veículo de comunicação número 1 do país”.

Fig. 17: Vinheta - O veículo de comunicação número 1 do país

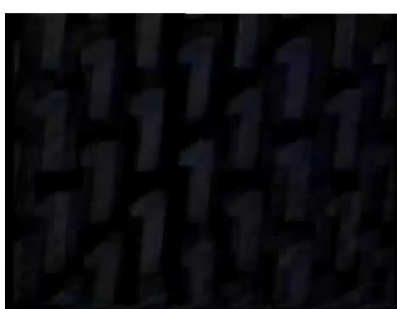

Fig. 17/1

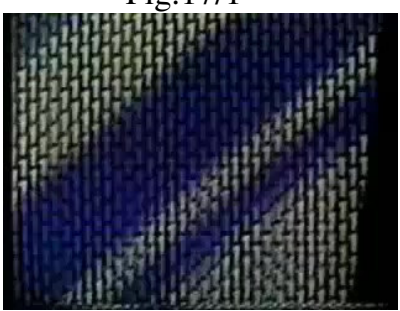

Fig. 17/4

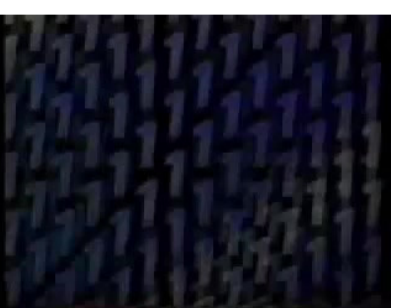

Fig. 17/2

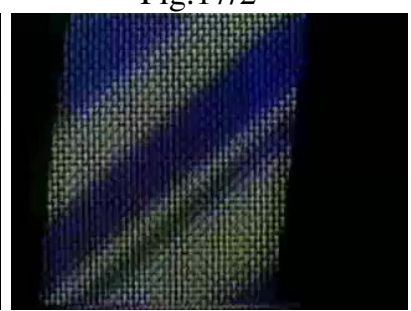

Fig. 17/5

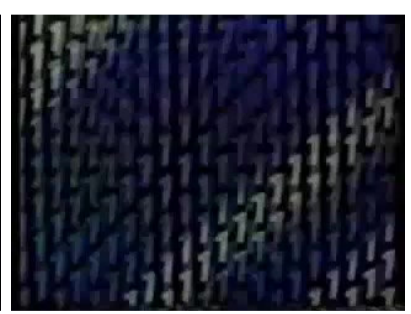

Fig. 17/3

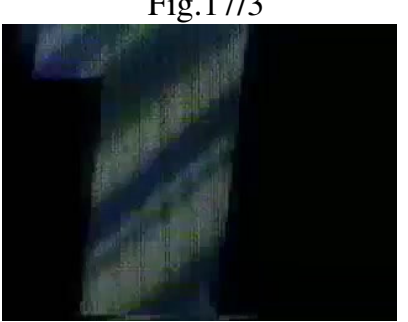

Fig. 17/6 


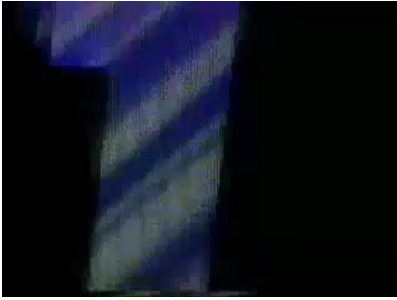

Fig. 17/7

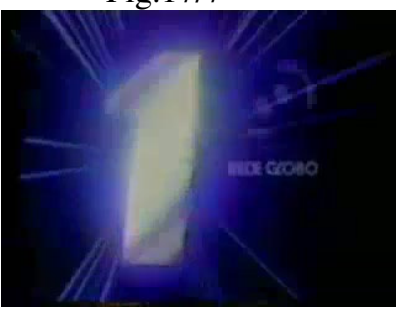

Fig. 17/10

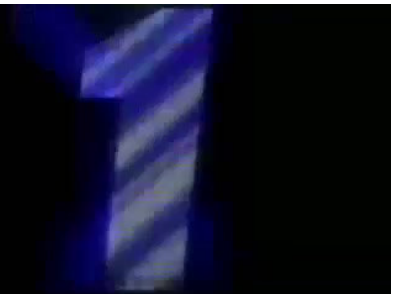

Fig. 17/8

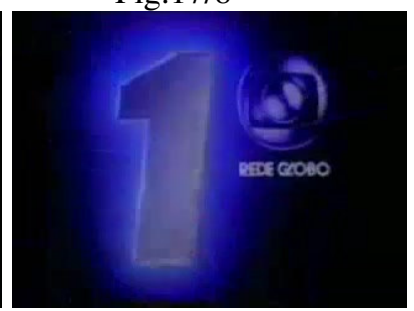

Fig. 17/11

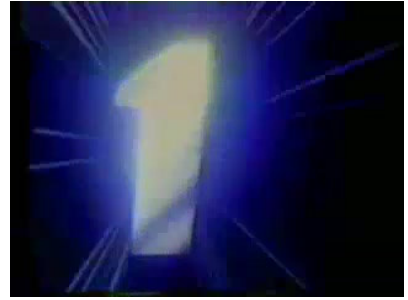

Fig.17/9

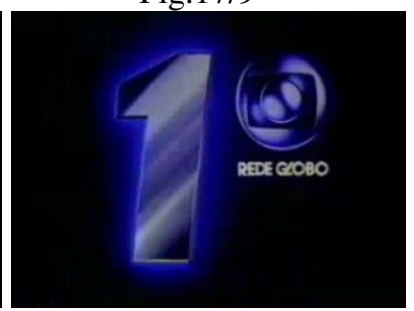

Fig. $17 / 12$

Há nas primeiras imagens do videografismo uma grande quantidade de números "1", todos bem pequenos e dispostos de modo organizado (fig. 17/1 a fig. 17/3). Conforme se opera um distanciamento desses pequenos pontos luminosos no decorrer dos quadros (fig. 17/4 a 17/8), percebe-se que estes formam no final o numeral "1" em tamanho maior e bem mais luminoso - pois resulta da reunião dos pequenos numerais que emanam luz (fig. 17/9 a fig. 17/12). Essa forma de articular o texto visual não se dá por acaso ou por simples gosto do artista criador. O que se coloca em evidência nessa vinheta são os pixels, os pequenos pontos luminosos responsáveis pela imagem-mosaico que se tem na televisão.

Como eles estão pulverizados e só conseguimos observar a imagem completa com certo distanciamento, tal como acontece na pintura com a técnica do pontilhismo, o movimento de câmera simulado na vinheta é em todo o tempo de zoom-out. Outro aspecto sobre o código televisivo é a percepção de certo distanciamento entre os pequenos números, indicando a existência de espaços vazios entre os pixels, numa referência à baixa definição da televisão analógica e à necessidade de participação do espectador, conforme explica Arlindo Machado:

Assim é que, se um espectador observa a informação luminosa que lhe é dada pelo iconoscópio de um aparelho receptor de tevê, ele se defronta com um sistema 'incompleto', cujas brechas precisam ser preenchidas para tornar perceptível/inteligível a imagem. No intervalo entre as retículas e no plano de separação das linhas de varredura há uma fresta vazia onde a figura simplesmente não existe; a própria figura está ela também anotada de forma simplificada, com uma quantidade limitada de pontos informacionais. Ver televisão significa, antes de mais nada, preencher os intervalos que fraturam a figura e completar os dados que foram suprimidos na enunciação (MACHADO, 1997, p. 60). 
"O veículo de comunicação número 1 do país" a que a vinheta faz referência em seu slogan é, portanto, a própria televisão - destacando o território de atuação da Rede Globo. Visto que é comum as vinhetas apresentarem um caráter bem mais abrangente e diversificado, conferindo mais ou menos a mesma ênfase a todos os elementos que compõe o projeto da marca, por que neste vídeo quase todo o discurso se concentra na questão do território, produzindo tantas referências direcionadas ao código televisivo? De acordo com Semprini, "o contexto está sempre integrado nas hipóteses de trabalho, de forma particular no interior dos mercados contemporâneos, eminentemente competitivos e saturados" (2006, p. 112). Desse modo, parece pertinente ter em consideração o fato de que, devido ao barateamento do aparelho no início dos anos 80, o meio televisivo pôde se popularizar e mostrar sua força. Tanto que em 1985, ano em que esta vinheta foi ao ar, a TV já abocanhava 59\% das verbas publicitárias, deixando para trás o jornal (15\%), a revista (17\%) e o rádio (6\%). A Globo, como empresa hegemônica no período, estava presente em 98\% do território nacional, com 70\% do total da audiência (MATTOS, 1990) - o que explica no discurso a projeção espacial "país" ter mais destaque (verbal-oral) que a projeção de nível global que o fundo preto infinito e a suspensão das imagens (expressivovisual - fig. 17/4 a fig. 17/12) podem fazer emergir, conforme normalmente se especifica a promessa de interação com o telespectador.

Assim, fazer um elogio ao veículo era a melhor estratégia para elogiar a si própria. A metáfora estava metalinguisticamente colocada. Sinônimo de televisão é Globo. Daí a utilização da logomarca da emissora na composição do numeral, indicando o $1^{\circ}$ lugar. $\mathrm{Ou}$ seja, ser a televisão o veículo número "1" do país resulta diretamente da participação da Globo como emissora. Todavia, para não parecer demasiadamente comprometido, o enunciador da mensagem investe, além do próprio recurso estratégico da metalinguagem que figurativiza "a televisão", de modo geral - em expressões em terceira pessoa como "o veículo" e no próprio nome "Rede Globo", que dá ideia de coletivo sem ter de projetar, como fez em outras vinhetas, formas dotadas de mais pessoalidade e proximidade, como um "nós". Assim, a emissora consegue criar um efeito de imparcialidade e, consequentemente, de verdade fundamentais para a crença do telespectador no dado apresentado - a estatística do primeiro lugar - e a efetivação de contratos.

Nesse sentido, vale a pena prestar atenção no aspecto metálico do numeral - $1^{\circ}$ (fig. 17/4, fig. 17/5, fig. 17/8 e fig. 17/12). Comumente associado à tecnologia - motivo pelo qual passa a ser utilizado na logomarca da emissora em 1988 - o cinza platinado remete o 
telespectador aos dispositivos e recursos avançados que tornam possível a produção da imagem eletrônica. Valor também retratado nos quadros que compõe a vinheta que, como busquei explicitar, se desenvolve em torno do código televisivo (fig. 17/1 a 17/12). Além disso, esse numeral exibe luz e brilho. Aspectos expressivos que conotam sentidos de magnificência, suntuosidade, celebridade, esplendor e glória. Todos eles apresentam absoluta coerência em relação ao lugar de destaque ao qual a emissora eleva o meio televisivo e a si própria - o topo, o primeiro lugar. Todos esses elementos instituem a Rede Globo não somente como o sujeito do saber-fazer, em razão do domínio que demonstra sobre a técnica e o código televisivo, mas também como o sujeito do poder-fazer, pois se seu modo de atuação lhe permitiu chegar ao lugar em que diz estar, quanto mais não poderá fazer agora que é a primeira, a mais poderosa e influente rede do país. E o que ela oferece ao telespectador? Imagem de qualidade. Esse sentido pode ser depreendido pelo próprio desenvolvimento da vinheta, inclusive porque ela parte de quadros com imagens de difícil reconhecimento (fig. 17/1 a fig. 17/3), dado o aspecto granuloso e fragmentado, quer dizer, parcial do objeto representado, e chega à exposição do objeto em seu todo, numa imagem sem qualquer tipo de ruído visual (fig. 17/10 a fig. 17/12). De modo que a vinheta demonstra ter sido trabalhada a partir de oposições como "todo" vs. "parte", "completo" vs. "incompleto", "nítido" vs. "embaçado" e "perfeito" vs. "defeito". Novamente, deve-se pensar na questão contextual, lembrando que nessa época exibir uma imagem de qualidade era realmente um diferencial em relação à concorrência. Assim, é possível chegar ao seguinte programa narrativo:

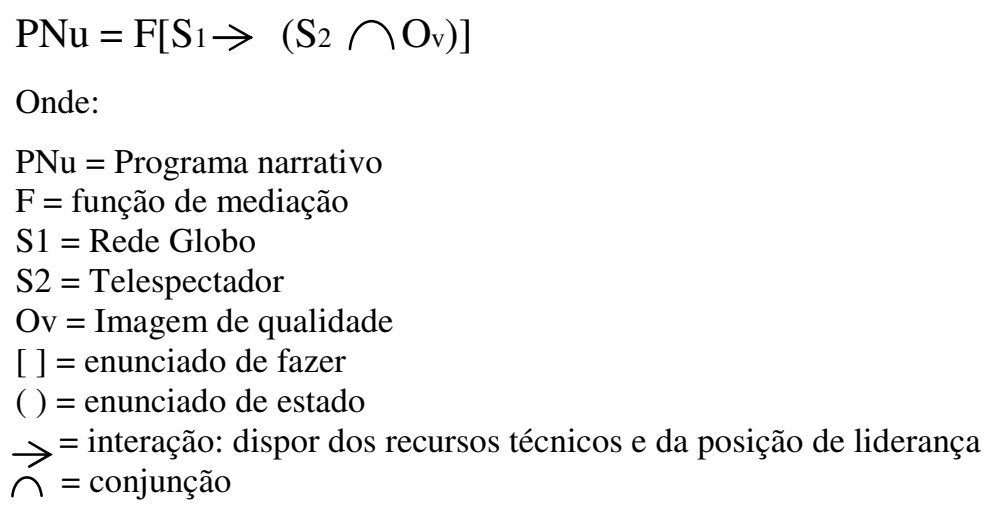

Este, todavia, não se configura como um programa narrativo de base, mas de uso. De acordo com Greimas e Courtés, "um PN simples se transformará em complexo sempre que exigir a realização prévia de um outro PN: é o caso, por exemplo, do macaco que, para 
alcançar a banana, deve primeiro procurar uma vara" (1973, p. 354). Adaptando o exemplo, o macaco, neste caso, é o telespectador. A banana é a comunicação - afinal, o slogan diz: "o veículo de comunicação nº 1 do país" - e a vara é a imagem de qualidade.

Quando vamos às correntes e aos modelos que contribuíram significativamente para o desenvolvimento das teorias da comunicação, como é o caso da pesquisa americana e, mais especificamente, o modelo de Shannon e Weaver, que sistematiza o processo comunicativo a partir de uma perspectiva puramente técnica, vemos que cuidados em torno, por exemplo, da noção de entropia (tendência à desorganização de uma mensagem note a oposição que emerge em relação à disposição organizada dos pequenos números “1”), de ruído (interferência que atua sobre o canal e atrapalha a transmissão - perceba o aspecto desfocado e incompleto das primeiras imagens da vinheta em relação à imagem final), de redundância (repetição utilizada para garantir o perfeito entendimento - observe as reiterações em torno no número "1" que aparece multiplicado em tamanho menor, depois unificado em tamanho maior e ao fim como numeral) e do próprio código (que orienta e atua no processo de produção da mensagem - a metalinguagem proposta no vídeo) - são pressupostos indispensáveis para a transmissão da informação, interferindo diretamente em sua qualidade e êxito (ARAÚJO, 2001, p. 121-122). Todavia, tais aspectos técnicos não chegam a estabelecer por si próprios a comunicação.

Conforme a etimologia da palavra, o termo "comunicação" revela a ideia de uma atividade realizada conjuntamente, a fim de romper o isolamento. Quer dizer, comungar, tornar comum - a promessa de interação da marca. Para alguns autores, o significado dessa "ação em comum" deve levar em conta que o "algo em comum" refere-se a um mesmo objeto de consciência e não a coisas materiais (MARTINO, 2001, p. 14). Dessa maneira, a menos que os conteúdos veiculados pelos meios sejam efetivamente compartilhados - o que envolve o fazer-interpretativo do sujeito que os recebe - não se pode falar exatamente em comunicação, como explica Duarte:

Os meios podem veicular informação e a veiculação da informação é uma das etapas do estabelecimento da comunicação, mas a veiculação por si não indica um fenômeno comunicacional se temos por comunicação os encontros perceptivos entre agentes e os produtos cognitivos que emergem (2003, p. 53). 
Considerar a comunicação como sendo uma relação entre consciências e seu objeto, por extensão, um objeto de consciência, é sem dúvida privilegiar o aspecto inteligível das relações comunicacionais. Ou seja, privilegiar a aquisição ou transformação de conhecimento por meio da cognição. Como exemplo, no caso da vinheta, trata-se de reconhecer os valores sobre os quais se constrói a identidade da emissora que a veicula, tal como procurei expor. Assim, voltando à ordem dos programas narrativos, a qualidade técnica da imagem que a Globo propõe visa, em última instância, como o próprio discurso destaca no slogan, uma efetiva relação de comunicação.

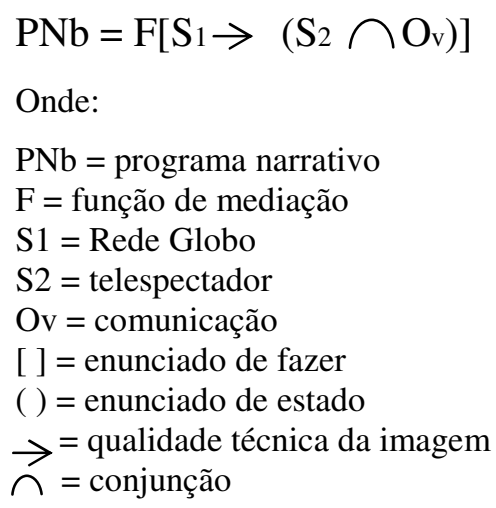

Retomando Greimás e Courtés, “o PN geral será, então, denominado de PN de base, enquanto os PN pressupostos e necessários serão ditos PN de uso: estes são em número indefinido, ligado à complexidade da tarefa a cumprir" (1973, p. 354). Sendo assim, a existência desses dois tipos de programas narrativos no discurso chamam a atenção para a complexidade envolvida em se estabelecer a função de mediação - quer dizer, a utilização dos meios a fim de estabelecer a comunicação - que é a própria enunciação fundamental da marca da Globo. Demonstrando o grau de dificuldade que isso envolve, o discurso promove ainda mais o brilhantismo da emissora por demonstrar que ela não apenas consegue ser bem-sucedida, realizando por completo a tarefa - quer dizer, os dois programas narrativos envolvidos nisso - mas a executa de modo a deixar a concorrência toda para trás. 


\begin{tabular}{|c|c|c|c|}
\hline \multirow{8}{*}{ 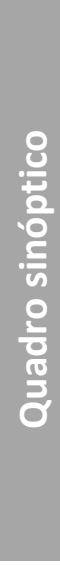 } & $\begin{array}{l}\text { Projeto } \\
\text { da marca }\end{array}$ & Temas & Figuras \\
\hline & $\begin{array}{l}\text { Enunciação } \\
\text { fundamental }\end{array}$ & Mediação & $\begin{array}{l}\text { "Rede Globo" (texto verbal-visual); "veículo" (texto verbal-oral); } \\
\text { Imagens da televisão (fig.17/1 a fig. 17/12) }\end{array}$ \\
\hline & Promessa & Interação & “comunicação" (texto verbal-oral) \\
\hline & $\begin{array}{l}\text { Especificação } \\
\text { da promessa }\end{array}$ & Nível Global & $\begin{array}{l}\text { "país" (texto verbal-oral); } \\
\text { cosmo: fundo preto infinito e imagens suspensas (fig. } 17 / 9 \text { a fig. 17/12) }\end{array}$ \\
\hline & Território & Televisão & Código televisivo: pontos luminosos, granulosos, movimento de zoom-out \\
\hline & Valores & Tecnologia & $\begin{array}{l}\text { Aspectos técnicos do vídeo (fig.17/1 a fig. 17/12); } \\
\text { Imagem metalizada (fig. 17/12) }\end{array}$ \\
\hline & Valores & Pluralidade & Reunião de muitos pontos informacionais ou pixels (fig. 17/1 a fig. 17/8) \\
\hline & Valores & $\begin{array}{l}\text { Estilo } \\
\text { clássico }\end{array}$ & Centralidade da imagem e utilização da logo (fig. 17/12) \\
\hline
\end{tabular}

\begin{tabular}{|c|c|}
\hline Espaciais & Cosmo: fundo preto infinito e imagens suspensas (fig. $17 / 9$ a fig. $17 / 12$ ) \\
\hline Actanciais & $\begin{array}{l}\text { "Rede Globo" - "ele" - enunciador coletivo (verbo-visual) } \\
\text { "O veículo" - "ele" - 3a pessoa (veral-oral) }\end{array}$ \\
\hline Temporais & ----------- \\
\hline
\end{tabular}

\subsubsection{Anagrama}

Todo anagrama é um jogo de linguagem - no mais amplo sentido que se tem do termo. Apesar disso, o conceito é quase sempre lembrado como uma espécie de rearranjo ou transposição de letras no intuito de formar novas palavras. Esse sentido é restritivo e parece ser consequência dos estudos de referência na área, que são de Saussure e estão voltados para a linguagem verbal escrita (STAROBINSKI, 1974). A ideia aqui é ir um pouco além e estender o conceito para o audiovisual - e, mais especificamente, para a televisão -, pensando o anagrama como um jogo de falas, gestos, cenas e até de destinadores e destinatários. Para demonstrar, utilizarei quatro vinhetas da série $A$ gente se liga em você, veiculada em 2011. 
$1^{\mathrm{a}}$ vinheta - Telejornalismo ${ }^{14}$

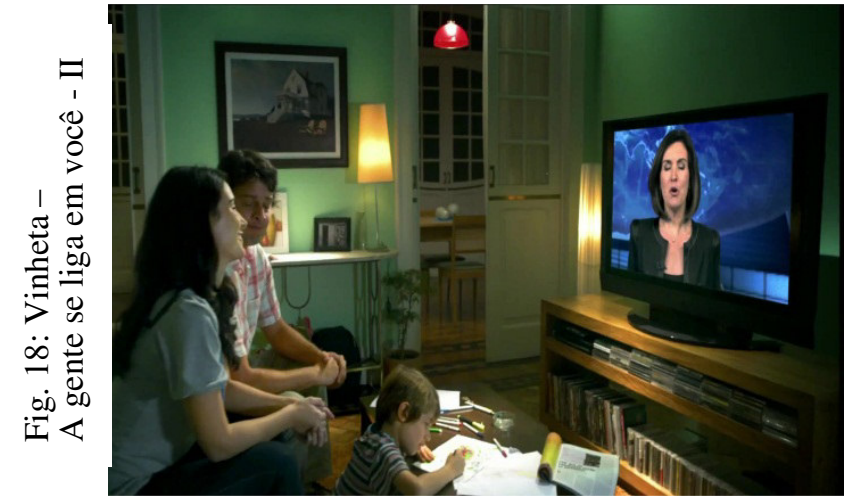

Fig. 18/1

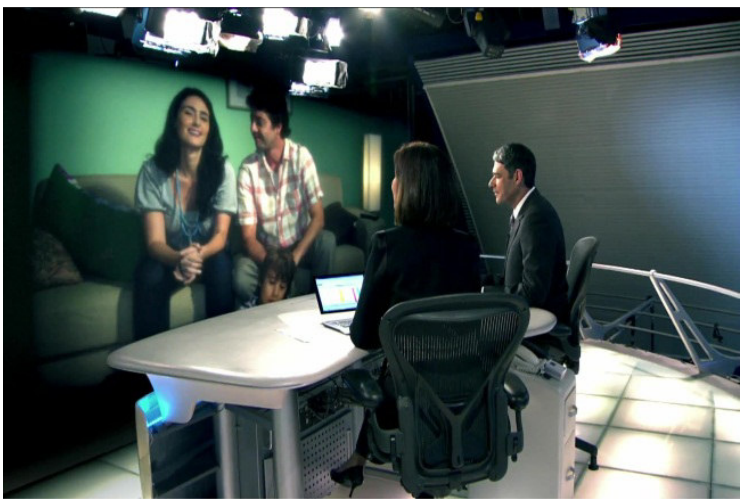

Fig. 18/2

Apresentadora: Presidente viaja para o encontro entre o G8.

Telespectador: Ué, e a CPI?

Telespectadora: Queria uma boa notícia.

Apresentadora: Descoberta revoluciona medicina.

Telespectador: Tá aí, você não queria uma boa notícia?

Giro da tela

Apresentador: No mercado de trabalho mulheres assumem cargos de confiança.

Telespectadora: Essa é a melhor.

Apresentadora: Agora, no Jornal Nacional.

$2^{\mathrm{a}}$ vinheta - Esporte ${ }^{15}$

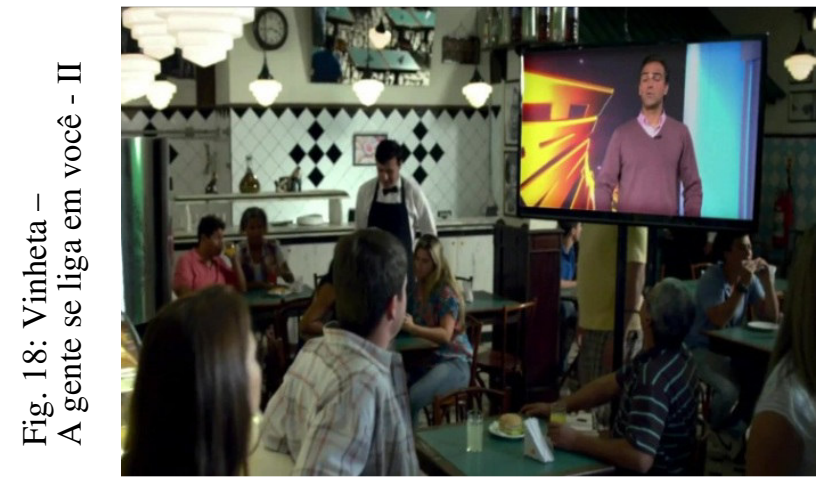

Fig. 18/3

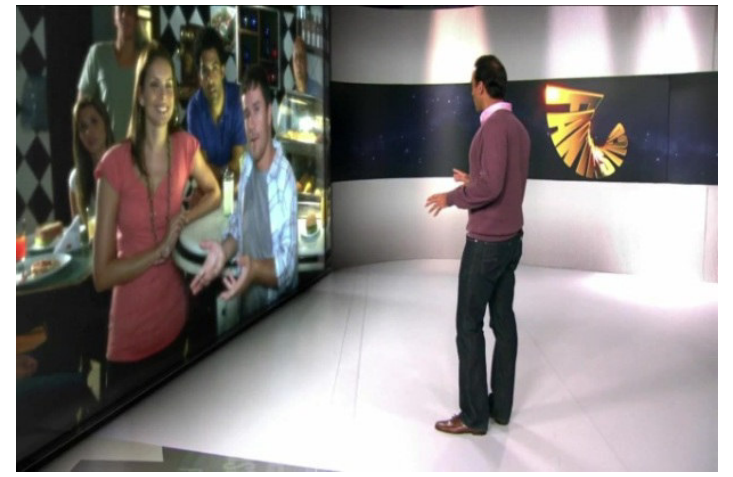

Fig. 18/4

Apresentador: Hoje teve clássico. E se tem clássico tem polêmica.

Telespectador: Eu quero saber é se foi pênalti.

Apresentador: Tá todo mundo querendo saber se foi pênalti. E a gente vai responder isso pra você.

Telespectadora: Se tivesse uma tela atrás do gol...

Giro da tela

Apresentador: Vamos ver agora uma imagem por trás do gol pra acabar com a discussão?

Telespectadora: Eu não falei que foi mão?

Apresentador: Pronto, não tem mais dúvida. Foi mão. E está inaugurado o bola murcha dos juízes. Isso é handebol seu juiz!

\footnotetext{
${ }^{14}$ Disponível em: http://www.youtube.com/watch?v=jKd_EEmoJfw\&feature=youtu.be

${ }^{15}$ Disponível em: http://www.youtube.com/watch?v=2HgmCr6j55A\&feature=youtu.be
} 


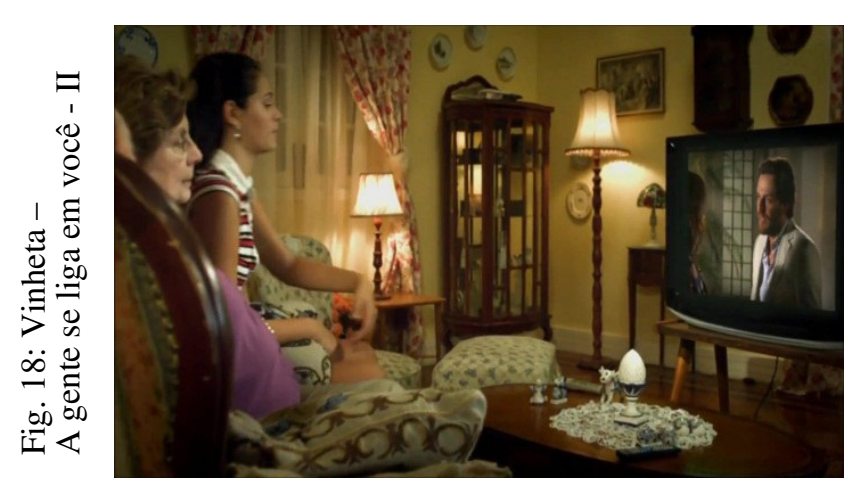

Fig. 18/5

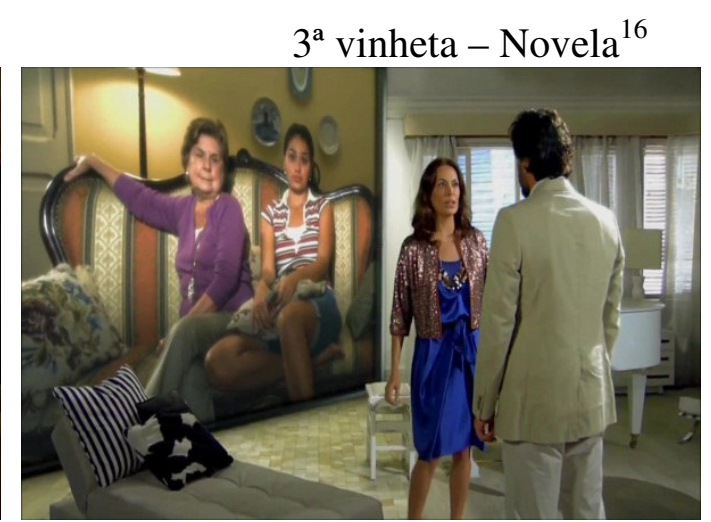

Fig. 18/6

Senhora: É a novela?

Jovem: É.

Novela - Herculano: Amanda, espera aí, eu amo você!

Senhora: não cai nessa, ele é picareta.

Novela - Amanda: Não sei Herculano, eu estou confusa.

Giro da tela

Senhora: Isso é coisa ruim. Não vale nada!

Novela - Amanda: Não aguento mais isso. Eu vou embora.

Jovem: É isso aí Amanda!

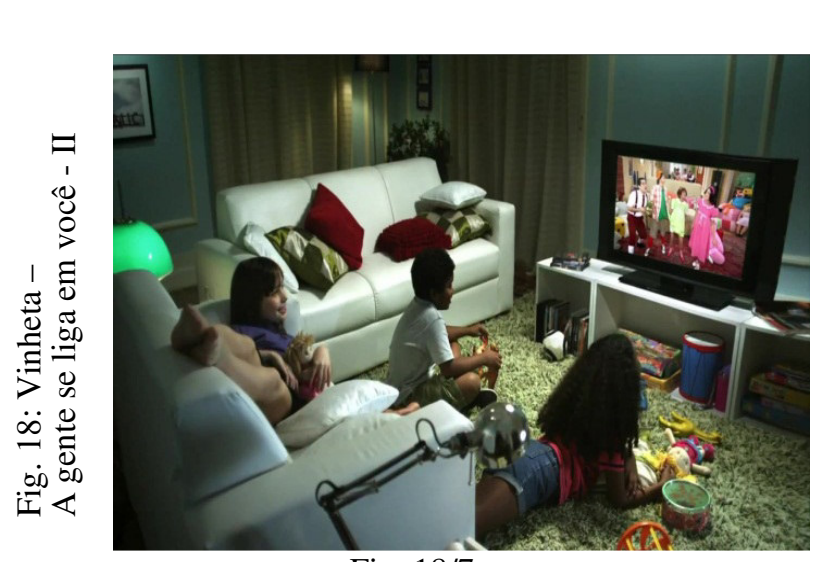

Fig. 18/7

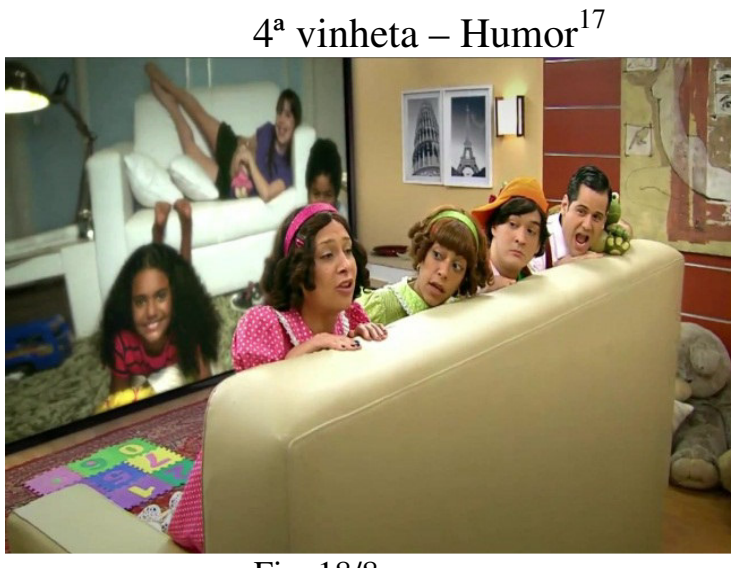

Fig. 18/8

Programa de Humor - Garoto:Hmm... Vocês estão sentindo esse cheirinho de "picoca"?

Crianças - Telespectadores: Não é "picoca!"

Programa de Humor - Garoto:É pipoca, seu burro!

Programa de Humor - Menina:Sua mãe só gosta de pipoca doce, não é?

Seu pai falou que ela vive fazendo um doce.

Programa de Humor - Garoto:Ai, ai, ai. É mentira, é mentira.

Giro da tela

Programa de Humor - Garoto: É nada, quer ver?

Programa de Humor - Menina: Ô pai, você não falou que o tio Délio vive reclamando que A tia Érica só faz doce?

\footnotetext{
${ }^{16}$ Disponível em: http://www.youtube.com/watch?v=RhHzyTmYz-4\&feature=youtu.be

${ }^{17}$ Disponível em: http://www.youtube.com/watch?v=RhHzyTmYz-4\&feature=youtu.be
} 
De modo geral, as mensagens se estruturam sobre o que chamarei de efeito espelhamento. Nas falas que se desenvolvem, apresentadores e público compartilham as mesmas preocupações, expectativas e valores. Mas não fazem isso por meio de um diálogo, como se conversassem através da tela que separa os dois espaços. Existe, antes, um posicionamento independente que coincide entre os dois lados e só acontece porque, conforme o slogan institucional - "A gente se liga em você" (texto verbal-oral) -, a Rede Globo conhece o seu público e traduz os seus anseios. Para além do texto-verbal, tal efeito de espelhamento se estabelece no vídeo com o posicionamento de uma tela entre os dois espaços e um jogo de câmera que intercala o foco da imagem nos diferentes personagens e ambientes, sugerindo na série um constante deslocamento nas figuras de destinador e destinatário da mensagem.

$\mathrm{Na}$ primeira vinheta, por exemplo, as imagens mostram a instalação de dois ambientes no discurso: a sala da casa de um telespectador e o estúdio de gravação de um telejornal. A velocidade com que se faz o corte das cenas e a troca de um ambiente por outro imita especificamente neste caso o próprio ritmo acelerado da "escalada" do programa $^{18}$, de modo que esta característica participa ativamente na construção de uma cena verossímil - como se se tratasse de uma edição "de verdade" do telejornal. As falas do público e as falas dos apresentadores são quase simultâneas, representando a agilidade do fazer-noticioso. De modo que no mesmo instante em que se coloca uma determinada questão ela é atendida do outro lado - tão rápida e compassadamente quanto os movimentos de um sujeito que, à frente do espelho, acompanha seus reflexos.

O modo como se estrutura o texto falado é outro ponto que chama a atenção. $\mathrm{O}$ fato de as preocupações do público masculino serem sempre transmitidas pelo narrador masculino do telejornal e as ansiedades do público feminino pela figura da apresentadora reforçam ainda mais a noção de espelhamento - colocando em evidência o valor de pluralidade que justifica a manutenção de um homem e uma mulher na bancada do telejornal. De modo que tudo o que se diz de um lado é retomado com propriedade do outro - quer dizer, com o conhecimento de causa que em alguns casos somente a questão do gênero permite ter.

Enquanto o texto-verbal se incumbe de revelar as preocupações que os diferentes atores compartilham, os recursos expressivos que mencionei caracterizam o dinamismo

\footnotetext{
18 "Escalada": jargão utilizado para designar o momento de abertura do telejornal, no qual se fazem as principais chamadas, responsáveis por "prender" ou "perder" o telespectador.
} 
dessa interação. Assim articulados, texto e imagem criam um contundente efeito de proximidade entre os agentes, mascarando os limites físicos impostos pelo quadro - o ecrã televisivo, que em nenhuma vinheta deixa de aparecer. Essa mesma estratégia - que revela e ao mesmo tempo esconde a presença do dispositivo técnico e, portanto, da mídia como instrumento da interação - está também presente no slogan da campanha, tendo em vista que a questão técnica em torno do "ligado" vs. "desligado" do aparelho ou monitor acaba sobrepujado pelo sentido de união - "estar junto", "ligado um no outro" - que o discurso promove.

Nesse mesmo estilo foi produzida a vinheta em torno do conteúdo de esporte da revista eletrônica. Nela, tem-se novamente a instalação de dois contextos, agora um bar e o estúdio, e tudo o que acontece no primeiro tem extensão no segundo, espelhando falas, gestos, posturas e assim por diante. A diferença é que neste vídeo os atores masculinos e femininos projetados são aparentemente mais jovens que na vinheta anterior. Além disso, o próprio cenário em que estes se inserem suscita uma condição diferente entre o público desta vinheta - que engloba jovens adultos, num bar, descontraindo-se entre amigos - e o da mensagem anterior - composto por um casal e uma criança. De modo que o tipo da programação - naquele caso, o telejornal; e, neste, uma revista eletrônica, acompanha coerentemente a variação do público, explicitando novamente o valor de pluralidade.

Esse sentido se reforça na vinheta que utiliza a novela como pano de fundo para demonstrar a afinação entre a emissora e o público. As telespectadoras que encarnam os papéis de "avó" e "neta" torcem para que a mocinha da trama não se deixe levar pela conversa sedutora do galã e a personagem na tela corresponde às expectativas. $\mathrm{O}$ espelhamento nesse caso fica por conta do sentimento compartilhado. E a questão de gênero é evidente. Um homem talvez torcesse para o galã conquistar a confiança da mocinha, mas as mulheres - que compõe majoritariamente o público desse tipo de produto televisivo - preferem que a personagem resista aos encantos do falastrão. O sentimento da mulher da trama é o sentimento da mulher da vida real. A decisão que uma toma é a decisão que a outra gostaria de tomar. E, não raras vezes, a ação da mocinha compensa a realização que não se pôde ter na vida real. Destaco ainda a utilização da telenovela como produção capaz de reunir em frente à tela diferentes gerações, escolha que - tais como as anteriores - encontra ecos na realidade, contribuindo para o efeito de verossimilhança intencionado na construção de cada cena - o que abrange a projeção de ambientes diferentes, utilização de certos tipos de objetos em detrimentos de outros, combinações de 
vestuário e adereços, e até mesmo a escolha de biotipos - conformando estilos autênticos para os ethos projetados.

Além do jornalismo, do esporte e da dramaturgia outros dois pilares da programação da Rede Globo são o humor e o nicho infantil, combinados numa outra vinheta da série. Nela, ao contrário das outras produções, quase não há intercalação de texto entre destinador e destinatário. As estratégias para criar a noção de espelhamento se destacam no cenário e nos personagens envolvidos. De um lado, a sala de uma casa qualquer. Do outro, no estúdio, a sala de uma casa fictícia. É quase tudo igual: sofás, tapetes, brinquedos e crianças. Entre os dois espaços apenas uma tela de televisão criando o efeito de que os meios reproduzem com veracidade as cenas do mundo real do telespectador.

Em todas essas vinhetas é possível perceber que, apesar de girarem em torno dos mesmos temas ou demonstrarem as mesmas expectativas e valores, as falas dos apresentadores ou personagens e público não seguem fielmente a mesma estrutura ou uso de vocábulos. Em alguns casos, ela quase nem existe, como no quadro de humor. E, no que diz respeito às imagens, acontece a mesma coisa. Embora a vinheta que acabei de mencionar reproduza na tela objetos que guardam algum grau de similaridade com os que pertencem ao telespectador projetado na peça, nas demais vinhetas o cenário em que está o destinador da mensagem é bem diferente do cenário em que está o destinatário. Então, se não há repetições exatas pode-se ainda falar em anagrama? Saussure registrou em seus manuscritos que o anagrama não deveria ser visto apenas como o resultado de uma inversão, mas como o próprio processo de inversão em si. E que o efeito poético já seria alcançado se o leitor fosse capaz de perceber a presença evidente, mesmo que dispersa, de uma segunda forma de escrever determinada palavra. Pode-se dizer que a mesma coisa acontece neste caso com as vinhetas. Apesar de não haver uma repetição exata dos elementos de áudio e vídeo, o telespectador percebe com facilidade as correspondências na tela, promovidas sobre deixas verbais, ritmo, elementos de cenário, formas de gestualidade, exploração de gênero, jogos de câmera etc.

Realizadas essas considerações acerca do anagrama como recurso estetizante, podemos passar a ver as especificidades de cada vinheta em função dos elementos que compõe o projeto da marca. O primeiro e mais evidente - porque está diretamente ligado ao efeito de espelhamento - é a presença, em todas as composições, de uma tela de televisão, que delimita o território de atuação da Rede Globo. Esse elemento figurativo e o 
sentido que ele evoca são reforçados pelas próprias atrações que são apresentadas nos monitores. Programas da emissora que o público está acostumado a ver e reconhece no vídeo como "reais", que de fato existem e fazem parte da grade da emissora. Além disso, essas aparições carregam seus apresentadores originais e todas as características expressivas que os programas têm, como ritmo, tipo de linguagem, elementos de cenário, proxêmica etc., criando um efeito de sentido de verdade.

O espaço intermediário que a tela ocupa nas cenas faz a distinção entre dois espaços diferentes: o da realidade e o da representação. Esta configuração não apenas coloca em evidência a função de mediação como enunciação fundamental, mas repete a própria construção da logomarca da emissora - "esfera", "retângulo", "esfera" - e o sentido que dela emerge. Não por acaso as imagens retratam "a televisão dentro do mundo", quer dizer, dentro dos estabelecimentos, das casas, dos lares de cada família, como também "o mundo dentro da televisão" ao realizar o giro de câmera e colocar todos esses elementos, por assim dizer, dentro dos estúdios de gravação.

Assim, os diferentes tipos de espelhamento que abordei na descrição das vinhetas refletem a promessa de interação que sustenta a enunciação fundamental da marca. $\mathrm{O}$ trabalho da emissora nesse sentido é representado como sendo de tanta eficiência que até num produto reconhecidamente mais fictício que os outros, como é o caso da dramaturgia, a telespectadora chega ao ponto de "falar com a personagem", aconselhando-a a agir de um modo em vez de outro, conforme o texto da vinheta em que a senhora de mais idade e, portanto, com mais experiência de vida, diz à mocinha da trama: "não cai nessa, ele é picareta".

Os atores que aparecem nessa e nas outras cenas, evidentemente, não são aleatórios. A ideia é retratar os diversos tipos de público que a emissora quer alcançar com os diferentes programas que articula em sua grade televisiva, conforme o valor de pluralidade presente na marca. Todavia, não faz isso projetando um público massificado, mas individualizado - "você" (texto verbal-oral e verbo-visual) - pois entende que a audiência depende do contrato a ser estabelecido com cada telespectador. Quanto ao enunciador, seu modo de projeção é coletivo - "a gente" (texto verbal-oral e verbo-visual) - valendo-se dos programas e profissionais de destaque envolvidos em cada um deles para dizer ao telespectador que as atrações resultam de um esforço conjunto no sentido de fornecer os conteúdos que o público quer ver. A ênfase, nesse caso, não está nem na atividade pessoal desses artistas nem no caráter agenciador da Globo, mas no próprio modo 
de produção e execução dos programas - daí a preocupação com a verossimilhança das cenas - e, consequentemente, da programação como um todo.

O efeito espelhamento que a vinheta coloca entre essas duas instâncias enunciador e enunciatário - expressa, portanto, o esforço da emissora em conquistar a audiência, dando a cada um dos indivíduos que a compõe aquilo que ele quer. Motivo pelo qual não somente o desfecho da história da mocinha na dramaturgia é exatamente aquele sugerido pela telespectadora, mas também as notícias que o telejornal dá são aquelas que interessam à família, os recursos que a revista eletrônica utiliza para tirar a dúvida da assistência são os que ela gostaria de ver, e as histórias para crianças fazem humor com elementos do próprio universo infantil. Em termos de narratividade, a atuação da Globo poderia ser formulada assim:

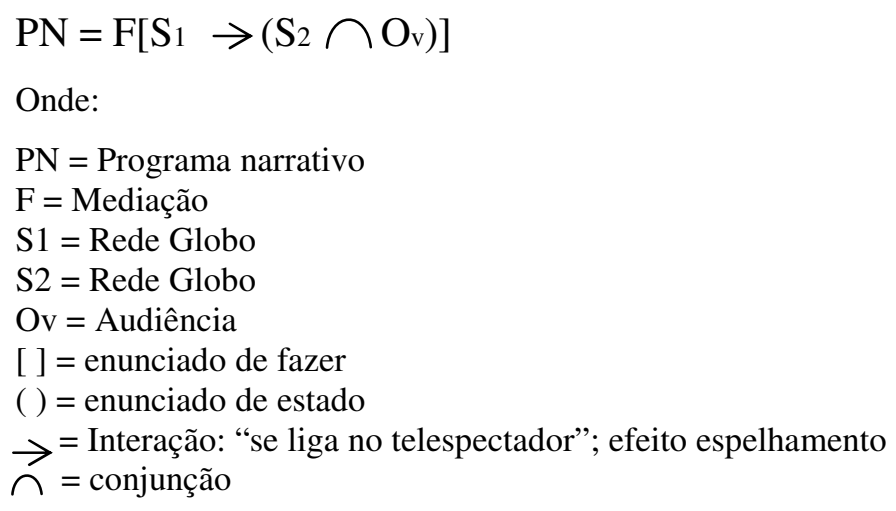

Outro aspecto a destacar é que em todas as vinhetas há um recurso que chamo de "giro de tela" ${ }^{19} "$, responsável por marcar uma mudança radical na perspectiva da imagem. É o momento em que o público deixa de contemplar as atrações para serem contemplados por elas, por assim dizer. Nas imagens que selecionei das quatro vinhetas, as que estão à esquerda se encaixam na primeira descrição (fig. 18/1, fig. 18/3, fig. 18/5 e fig. 18/7), e as que estão à direita, na segunda (fig. 18/2, fig. 18/4, fig. 18/6, fig. 18/8). O ponto alto está sobre a investidura tecnológica que esse momento de troca recebe. Durante o giro, a tela se expõe como uma imensa nuvem de elétrons, transformando-se numa espécie de portal por meio do qual se pode ir e vir, quer dizer, entrar e sair de duas dimensões absolutamente diferentes: o espaço da realidade e o espaço da representação (fig. 18/9). Num outro tipo de narrativa - contos maravilhosos, por exemplo - esse momento talvez fosse representado com elementos próprios do sonho, da imaginação ou da magia, mas nesta vinheta

\footnotetext{
${ }^{19} \mathrm{O}$ "giro de tela" está sinalizado no interior do texto de cada peça.
} 
institucional atrela-se aos componentes do meio e coloca em destaque a tecnologia como um valor na realização das interações que promete ter com o público.

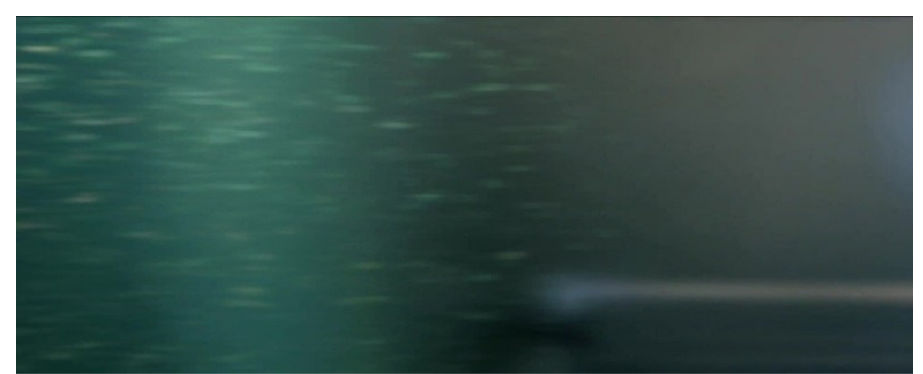

Fig. 18/9

Os diversos programas retratados são algumas das mediações que a Globo realiza e oferece ao telespectador. Todos são veiculados nacionalmente. Apesar disso, a vinheta acerca do telejornalismo mostra que a emissora também se preocupa em colocar o público em contato com o que se passa fora dos limites do território nacional, ampliando sua esfera de atuação e especificando a promessa de interação como global. Nesse sentido, note a frase da primeira notícia veiculada: "Presidente viaja para o encontro do G8" - retratando, portanto, eventos internacionais. Por fim, o modo ordenado e estável de apresentação da vinheta, seguindo sempre o mesmo padrão, e a qualidade das imagens retratadas, que primam por composições harmônicas em vez de ruidosas, refletem o estilo clássico presente no projeto como um valor norteador.

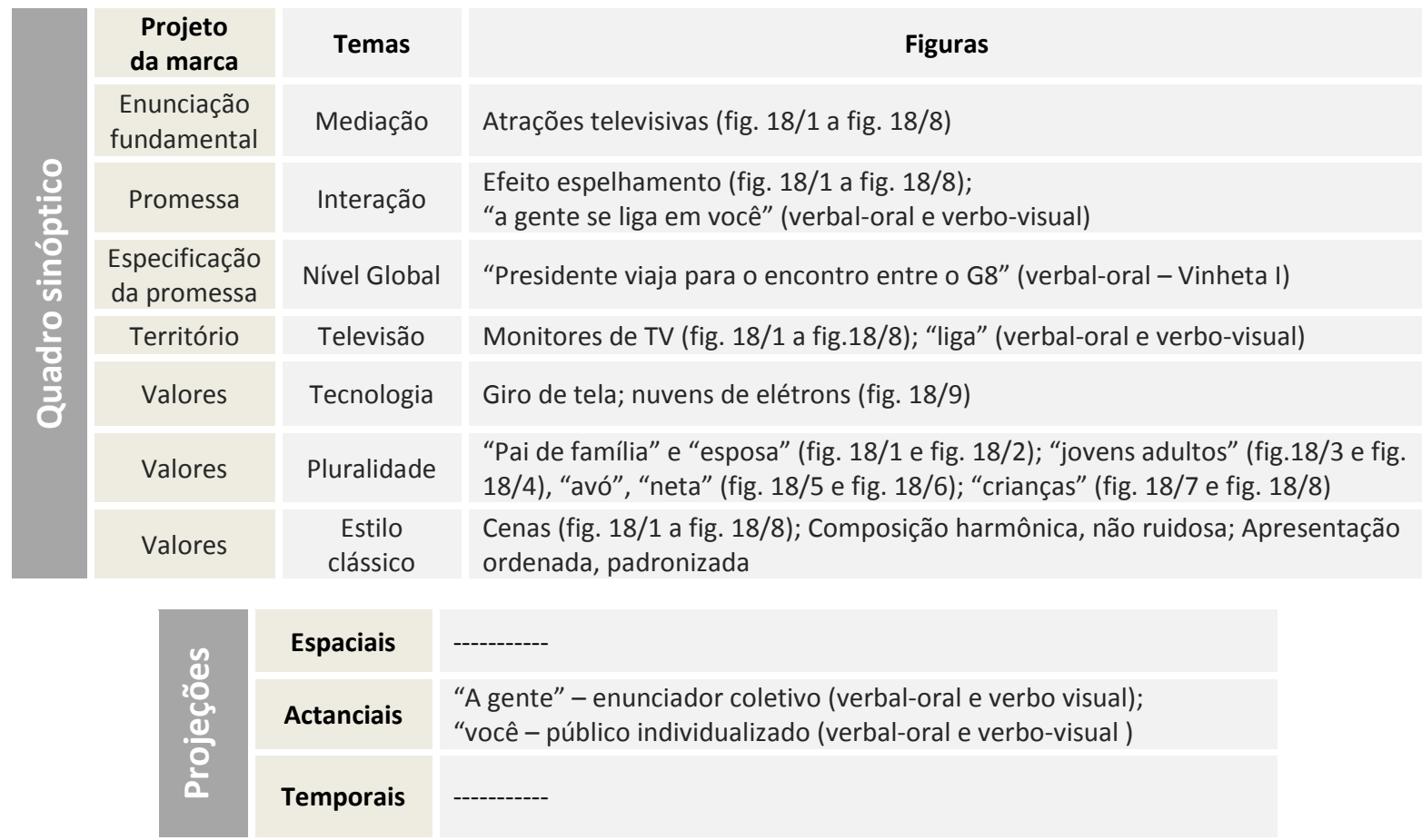




\section{Considerações preliminares}

As formulações semióticas que puderam ser depreendidas por meio das análises revelam dados interessantes. O primeiro deles é que todas as manifestações se organizam a partir de uma mesma "função", que é a de "mediação", e, consequentemente, a partir de uma mesma oposição fundamental: "representação" vs. "realidade" - aquilo que está dentro e o que está fora do quadro; o mundo imaginário e o mundo natural; a lente da câmera e o olho humano, a informação dos meios e a comunicação entre os indivíduos; os programas da televisão e a vida de verdade. E o sentido caminha tanto da representação para a realidade como da realidade para a representação:

\section{Eixo dos contrários}

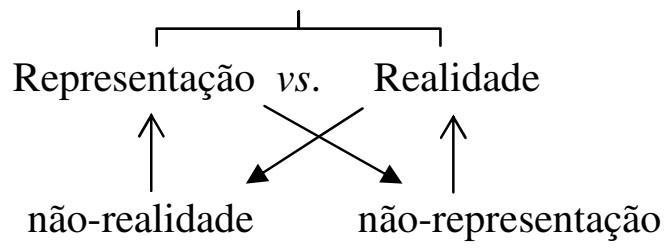

De maneira mais precisa, deve-se observar que as manifestações não privilegiam ora um sentido, ora outro. Antes, são desenvolvidas mantendo e articulando os dois termos em oposição, concomitantemente. Isso é possível porque estes estão em uma relação de contrariedade. Conforme Greimas e Courtés, "contrariedade é a relação de pressuposição recíproca que existe entre os dois termos de um eixo semântico, quando a presença de um deles pressupõe a do outro e, vice-versa, quando a ausência de um pressupõe a do outro" (1983, p.83). Assim, a mesma natureza mítica que se encontra na logomarca - formulada a partir da co-existência de termos contrários, como explicitei no primeiro capítulo - mostrase igualmente presente nas vinhetas institucionais.

Por repetir o princípio estruturador da logo, tais manifestações retomam o papel intermediário dos meios - mais especificamente a televisão - e isso explica o fato de a função de mediação estar presente em todos os programas narrativos. Visto que é a emissora quem propõe o contrato é sempre ela também o sujeito da ação $\left(\mathrm{S}_{1}\right)$. Outra constante é que enquanto a empresa televisual, por razões evidentes, é projetada nos discursos como uma entidade coletiva ("nós", "a gente”), o enunciatário, apesar de compor uma grande massa de telespectadores, é projetado de maneira individual ("você”), pois a audiência que a televisão almeja depende de sanções positivas em base particular. Por esse 
motivo, o contrato proposto não se dirige ao todo, mas a cada parte que o compõe. E, por fim, os valores em jogo são exatamente os mesmos que a logomarca propõe: tecnologia e pluralidade, conservando o estilo clássico.

Assim, é possível perceber pelas análises que as diferentes manifestações da marca no âmbito da comunicação não só cumprem a risca os componentes descritos por Semprini - enunciação fundamental, promessa, especificação da promessa, território e valores como se ocupam de fazer isso por meio de variados recursos estetizantes, primando pela valorização da carga de estímulos aos órgãos do sentido ao se trabalhar as diversas linguagens que atuam em sincretismo. Por que isso acontece? Há pelo menos três razões fundamentais, que destaco: a primeira é que tal tratamento estético permite diferenciar a própria marca das outras, exprimindo uma criatividade e uma originalidade marcantes. A segunda é que estetizar permite exprimir melhor o projeto de uma marca, otimizando sua força expressiva e multiplicando as chances de chamar a atenção do público. Afinal, se o plano da manifestação não for capaz de atrair a atenção dos receptores e ativar o processo interpretativo, o projeto de marca nunca será descoberto - e se perderá (Semprini, 2006, p. 195-96). Tem-se aqui, portanto, duas articulações diferentes. Uma da ordem do inteligível, referente ao projeto da marca, e outra da ordem do sensível, que corresponde às manifestações da marca. Se o termo "contrato" pode ser definido como "o fato de estabelecer, de 'contrair' uma relação intersubjetiva que tem por objetivo modificar o estatuto (o ser e/ou parecer) de cada um dos sujeitos em presença" (GREIMAS; COURTÉS, 1983, p.84), ao analisar as manifestações da marca no âmbito da comunicação somos levados a crer que os contratos que se estabelecem com o telespectador se dão, sempre, primeiramente, pelas vias do sensível. Um contrato estésico que não apenas antecede os demais, tais como o cognitivo ou o pragmático, mas, sobretudo, estabelece condições para que estes últimos se efetuem. E a terceira é que, efetuados os contratos, as experiências sensíveis que tais estetizações promoveram também contribuem para que a imagem positiva criada pelo enunciador permaneça por mais tempo na cabeça do enunciatário e, consequentemente, no imaginário coletivo. 


\subsection{Recursos sonoros - Elementos de identidade}

Como temos visto, as vinhetas institucionais são produzidas a partir da articulação de diferentes linguagens, constituindo um texto sincrético. Esta segunda parte do capítulo tem por objetivo apresentar algumas estratégias utilizadas pela Rede Globo no que diz respeito à linguagem sonora. Isso inclui músicas, jingles, spots e ruídos. Todos esses recursos podem ser empregados na construção de uma vinheta e, muitas vezes, isso se dá de modo integrado. Ou seja, da mesma forma que se pode ter uma peça composta apenas por música, ou spot, jingle ou ruído, pode haver também a utilização conjunta desses elementos, tal como música e spot, spot e jingle, jingle e ruído, e assim por diante. Parece importante, portanto, compreender o que caracteriza cada um desses recursos e como costumam ser empregados nesse tipo de manifestação da marca.

\subsubsection{A música}

O primeiro deles, a música, é geralmente uma composição feita sob medida para a peça visual que acompanha, e sua principal função está em criar a atmosfera ideal para a transmissão dos conteúdos. Embora algumas vinhetas se sustentem sem qualquer tipo de verbalização o mais comum é que sejam produzidas com base em um slogan. $\mathrm{O}$ teor da mensagem pode ser de alegria, suspense, urgência, amizade, enfim, assuntos ligados à televisão e a seus programas. Em todos esses casos, é comum a música ser responsável por estabelecer a ambientação correspondente a cada tema.

Um exemplo nesse sentido é a campanha do slogan "A gente se liga em você", de 2011. Na primeira vinheta da série ${ }^{20}$, a função de mediação que a emissora propõe se pauta na interação entre enunciador e enunciatário, comparando a atividade que desenvolvem através da televisão com as relações familiares e de amizade que se realizam face a face no cotidiano. Em vista das figuras que propõe o discurso, há em background uma trilha melódica, calma, afetuosa, que envolve emocionalmente o telespectador sem que ele perceba exatamente sua atuação. É uma estratégia que prima pela inaudibilidade da música, deixando-a em segundo plano em relação às imagens da tela e ao texto falado.

\footnotetext{
${ }^{20}$ Disponível em: https://www.youtube.com/watch?v=mbWh_cHaLOY
} 
Com isso, apesar de não se focar na música, o telespectador é completamente sensibilizado por ela - mais ou menos como costuma acontecer em cenas românticas de filmes e novelas.

Outro exemplo, mas agora em caráter diametralmente oposto, é a vinheta do Plantão da $\mathrm{Globo}^{21}$. Aqui a música ganha prioridade em relação à imagem e instaura abertamente um clima de tensão. Investe-se, portanto, na audibilidade da música, que é alta e em ritmo acelerado, despertando os sentidos do telespectador para o conteúdo que seguirá - geralmente temas de interesse público, de bastante gravidade ou que causam grande comoção, justificando a atmosfera de tensão evocada pelos elementos sonoros.

A música é capaz também de evocar contextos culturais e a série "A gente se vê por aqui ${ }^{22, " ~ e ́ ~ p r o v a ~ d i s s o . ~ C o m o ~ a ~ i d e i a ~ d a ~ c a m p a n h a ~ e r a ~ m o s t r a r ~ q u e ~ t o d a s ~ a s ~ p a r t e s ~ d o ~}$ país tinham visibilidade garantida na Globo a emissora lançou diversas vinhetas e a estratégia foi apresentar em cada uma delas imagens características de cada região. Com a trilha sonora não foi diferente. Embora o tema musical fosse o mesmo para todas, a melodia variava de acordo com os ritmos típicos de cada lugar - estilos que representavam os diversos contextos culturais apresentados. Desse modo, ainda que o telespectador não reconhecesse o lugar pelos elementos de vídeo, se situaria a partir do áudio.

\subsubsection{Spots e jingles}

Mesmo entre os profissionais da área de comunicação, spot e jingle são termos comumente utilizados de modo errôneo, sem muito critério. Vale a pena, portanto, iniciar este tópico com a definição de cada um deles. Spot publicitário é uma locução de curta duração, que pode ser feita por uma ou mais vozes e conter efeitos sonoros e música de fundo. É uma produção essencialmente comercial utilizada para anunciar marcas, produtos ou serviços. O jingle também é uma produção comercial, mas diferentemente do spot sua base não é a locução, mas a música. A mensagem publicitária é cantada em vez de falada, o que facilita a memorização e a afetividade por parte do público.

\footnotetext{
${ }^{21}$ Disponível em: http://www.youtube.com/wach?v=wzeggxMh3qo\&feature=youtu.be

${ }^{22}$ Vinhetas da série disponíveis em: http://www.youtube.com/watch? $\mathrm{v}=\mathrm{jckba0BO} 2 \mathrm{w} 8$ http://www.youtube.com/watch?v=EPwVdv8AkhU http://www.youtube.com/watch?v=pQfqwDGi4LQ http://www.youtube.com/watch?v=HmpU9dfqIDs http://www.youtube.com/watch?v=Lq8HctOVT61
} 
Feitas essas considerações, de que tratam os spots e jingles das vinhetas da Rede Globo? Que temas privilegiam? Sabendo que as vinhetas institucionais, de modo geral, são construídas para "emplacar" slogans realizei o seguinte levantamento:

Quadro1: Slogans Rede Globo

\begin{aligned} & Tipo Ano \\ & Spot 1975 \\ & Spot $1980-1981 \\ &$ Spot $1980-1981 \\ &$ Spot $1982-1983 \\ &$ Spot $1984-1985 \\ &$ Jingle 1985 \\ & Spot 1985 \\ & Jingle $1986-1987 \\ &$ Jingle $1987-1988 \\ &$ Spot 1989 \\ & Jingle $1989-90 \\ &$ Spot $1991-1997 \\ &$ Spot 1997 \\ & Spot 1993 \\ & Spot 1995 \\ & Spot 1996 \\ & Spot 1996 \\ & Spot $1996-1997 \\ &$ Spot $1997-1998 \\ &$ Spot 1998 \\ & Spot 1998 \\ & Spot 1999 \\ & Spot 1999 \\ & Spot $1999-2000 \\ &$ Spot 2000 \\ & Spot 2000 \\ & Spot 2001 \\ & Spot $2006-2007 \\ &$ Spot $2011-2012 \\ &$ Spot 2014 \\ & \\ & \hline\end{aligned}

\section{Slogan}

Hoje é juventude, 10 anos e aí estamos nós, caminhando com você

Agora mais um campeão de audiência

Vem aí mais um campeão de audiência

Essa gente que você não vê, faz a televisão que você vê

No pique da Globo, e Entre no $\mathrm{Ar}$

O que pinta de novo, pinta na tela da Globo

O veículo de comunicação número 1 do país

Vem que tem, na Globo tem

Pega essa onda, essa onda pega

A Globo pega pra valer

A Globo 90 é nota 100

Globo e você, tudo a ver

Globo e você, toda hora tudo a ver

A Globo vira e mexe, mexe com você

30 anos. Globo e você, tudo a ver

Esse mundo é todo seu

Mundo on-line. Globo e você tudo a ver

A Globo bola o que rola

Quem tem Globo, tem tudo

Um caso de amor com você

Um caso de amor com o Brasil

Uma nova emoção a cada dia

Tá todo mundo de olho na Globo

Globo 2000, no coração do Brasil

Emoção à vista

35 anos no coração do Brasil

A gente se vê por aqui

Só se vê na Globo

A gente se liga em você

A Globo está em movimento para acompanhar a vida, o mundo e você

Trata-se de uma listagem histórica dos slogans da Rede Globo, com informações sobre o ano de veiculação das peças e o tipo de apresentação sonora utilizada. O quadro foi feito com base na inteligência coletiva, quer dizer, no trabalho de várias pessoas que anonimamente dispuseram na internet dados de seu acervo pessoal sobre o tema. Apesar da possibilidade de não estar completa - já que não é oficial -, a lista nos ajuda em muitos aspectos.

Dessa relação, por exemplo, pode-se dizer que a maioria das vinhetas, em termos sonoros, é feita em forma de spots. Os slogans são narrados geralmente de modo simples - 
quer dizer, por uma única voz - e com alguma música ou ruído de fundo. Isso acontece em 26 das 30 vinhetas elencadas. Depois seguem os jingles, que aparecem somente 5 vezes. Em "O que é bom está na Globo", "O que pinta de novo, pinta na tela da Globo" e "Vem que tem, na Globo tem" somente os slogans são musicados. Já no caso de "Pega essa onda ${ }^{23}$ " e "A Globo 90 é nota $100^{24, "}$ produziu-se uma música completa para cada um deles. Mas, evidentemente, estes não são os únicos jingles institucionais da Globo. Apesar de não figurarem na lista anterior por não terem por base um slogan, os jingles que aparecem anualmente na televisão por ocasião do carnaval ${ }^{25}$ e da virada do ano ${ }^{26}$ possuem grande penetração e já se tornaram "hinos" da emissora, por assim dizer.

Estes dois últimos jingles - "Samba da globalização" e "Um novo tempo" possuem uma importante característica em comum: ambos marcam um período específico do ano. Quando surgem no ar, o telespectador sabe exatamente a que evento se refere cada um deles. Essa estratégia sonora é chamada leitmotiv, que traduzido do alemão significa "motivo condutor". O conceito nasceu na ópera e foi amplamente utilizado no cinema, em clássicos como "O poderoso chefão", "Indiana Jones" e "Tubarão". Por repetição, o leitmotiv pode marcar um personagem, sentimento ou tema numa narrativa. E embora seja utilizado na grande maioria dos casos em produtos fechados, quer dizer, com início e fim bem definidos - como a música ou o cinema - o conceito pode ser estendido a produções que se abrem no tempo e no espaço, como é o caso da programação televisiva. Nos dois casos que citei, a aparição dos jingles durante vários anos, repetidamente, fez com que se criasse uma verdadeira relação de identidade entre suas respectivas sonoridades e a emissora. De modo que as pessoas as associam à Rede Globo, reconhecendo-as como institucionais e referenciais de uma época específica do ano.

Esse mesmo fenômeno acontece também em outros tipos de sonoridades, como a música do "Plantão da Globo" e o "Plim-Plim", característico da emissora. No primeiro,

\footnotetext{
${ }^{23}$ Disponível em:

http://www.youtube.com/watch?v=HQ9bP6goKS0\&feature=g-upl\&context=G22d228eAUAAAAAAANAA

${ }^{24}$ Disponível em:

http://www.youtube.com/watch?v=1JfK1bbYsGc\&feature=g-upl\&context=G2e6a3efAUAAAAAAASAA

25 "Samba da Globalização". Composição de Hélio de La Peña, Franco Lattari, Um Chebabi, Rita de Cássia e Arlindo Cruz. Versões disponíveis em:

http://www.youtube.com/watch?v=ITdn-5XjD-Y\&feature=youtu.be http://www.youtube.com/watch?v=7BDJNOEVCKE\&feature=youtu.be http://www.youtube.com/watch?v=wUI-rtzZYvk\&feature=youtu.be http://www.youtube.com/watch?v=tJh4jNkn0Dc\&feature=youtu.be 26 "Um novo tempo". Música de Marcos Valle, Paulo Sérgio Valle e Nelson Motta. Disponível em: http://www.youtube.com/watch?v=2dirRZGyDXw\&feature=youtu.be
} 
quando as pessoas escutam o ritmo acelerado da vinheta sabem exatamente de que situação se trata e em que emissora, ou seja, sabem que alguma coisa de grande importância aconteceu e que a Globo precisa colocar a informação no ar com urgência. No segundo, não se tem uma música, mas um ruído. Pelo modo intencional como é empregado e sua persistência no ar, o plim-plim constitui-se também elemento de identidade sonora.

Todos esses exemplos nos encaminham para o reconhecimento do papel da linguagem sonora em promover o que se chama de autorreferencialidade. Essa característica faz parte da estética televisiva ${ }^{27}$ e daqui em diante tratarei de refletir um pouco mais acerca do que esses spots e jingles dizem a respeito da emissora. Para isso, quero chamar a atenção para o conteúdo do quadro a seguir, uma vez que nele os lemas que resumem a identidade da Rede Globo são confrontados com os próprios elementos que constituem o projeto da marca: a mediação como enunciação fundamental, a interação como promessa, o caráter global que especifica a promessa, a televisão como território, e a tecnologia e a pluralidade como valores.

O principal aspecto que salta à vista é que todos os slogans mantêm estreita relação com o projeto da marca. As construções tendem a ser polissêmicas, explorando mais de um elemento ao mesmo tempo e confirmando Semprini ao dizer que "a aparente simplicidade destes lemas esconde, na realidade, um trabalho extremamente complexo de esclarecimento, seleção e de organização" (2006, p. 124). Vejamos caso a caso as estratégias de abordagem ${ }^{28}$ :

\footnotetext{
${ }^{27} \mathrm{Cf}$. Apêndice I - Vinheta de TV: tipos, usos e funções

${ }^{28}$ Cf. Apêndice II - Rede Globo: slogans e identidade
} 
Tabela: slogans e identidade

\begin{tabular}{|c|c|c|c|c|c|c|}
\hline Ano & Slogan & $\begin{array}{l}\text { En.Fun. } \\
\text { (Mediação) }\end{array}$ & $\begin{array}{c}\text { Prom. } \\
\text { (Interação) }\end{array}$ & $\begin{array}{l}\text { E. Prom. } \\
\text { (Global) }\end{array}$ & $\begin{array}{c}\text { Territ. } \\
\text { (Televisão) }\end{array}$ & $\begin{array}{l}\text { Valores } \\
\text { (Tec/Plur.) }\end{array}$ \\
\hline $\begin{array}{l}1975 \\
1975 \\
\end{array}$ & $\begin{array}{l}\text { Hoje é juventude, } 10 \text { anos e aí estamos } \\
\text { nós, caminhando com você }\end{array}$ & & $\checkmark$ & & $\checkmark$ & \\
\hline $\begin{array}{l}1980 \\
1981\end{array}$ & $\begin{array}{l}\text { Agora, mais um campeão } \\
\text { de audiência }\end{array}$ & $\checkmark$ & $\checkmark$ & & $\checkmark$ & $\checkmark$ \\
\hline $\begin{array}{l}1980 \\
1981\end{array}$ & $\begin{array}{l}\text { Vem aí mais um } \\
\text { campeão de audiência }\end{array}$ & $\checkmark$ & $\checkmark$ & & $\checkmark$ & $\checkmark$ \\
\hline $\begin{array}{l}1982 \\
1983\end{array}$ & $\begin{array}{l}\text { Essa gente que você não vê, faz a } \\
\text { televisão que você vê }\end{array}$ & $\checkmark$ & $\checkmark$ & & $\checkmark$ & \\
\hline $\begin{array}{l}1984 \\
1985\end{array}$ & $\begin{array}{l}\text { No pique da Globo, } \\
\text { e entre no Ar }\end{array}$ & $\checkmark$ & $\checkmark$ & & $\checkmark$ & $\checkmark$ \\
\hline $\begin{array}{l}1985 \\
1985\end{array}$ & $\begin{array}{l}\text { O que pinta de novo, } \\
\text { pinta na tela da Globo }\end{array}$ & $\checkmark$ & & $\checkmark$ & $\checkmark$ & $\checkmark$ \\
\hline $\begin{array}{l}1985 \\
1985\end{array}$ & $\begin{array}{l}\text { O veículo de comunicação } \\
\text { número } 1 \text { do país }\end{array}$ & $\checkmark$ & $\checkmark$ & & $\checkmark$ & \\
\hline $\begin{array}{l}1986 \\
1987\end{array}$ & $\begin{array}{l}\text { Vem que tem, } \\
\text { na Globo tem }\end{array}$ & & $\checkmark$ & & $\checkmark$ & $\checkmark$ \\
\hline $\begin{array}{l}1987 \\
1988\end{array}$ & $\begin{array}{l}\text { Pega essa onda, } \\
\text { essa onda pega }\end{array}$ & & $\checkmark$ & & $\checkmark$ & $\checkmark$ \\
\hline $\begin{array}{l}1989 \\
1989 \\
\end{array}$ & $\begin{array}{l}\text { A Globo } \\
\text { pega pra valer }\end{array}$ & & $\checkmark$ & & $\checkmark$ & $\checkmark$ \\
\hline $\begin{array}{l}1990 \\
1990\end{array}$ & $\begin{array}{l}\text { A Globo } 90 \\
\text { é nota } 100\end{array}$ & $\checkmark$ & & & $\checkmark$ & \\
\hline \begin{tabular}{|l|}
1991 \\
1997 \\
\end{tabular} & $\begin{array}{l}\text { Globo e você, } \\
\text { tudo a ver }\end{array}$ & $\checkmark$ & $\checkmark$ & $\checkmark$ & $\checkmark$ & $\checkmark$ \\
\hline $\begin{array}{l}1996 \\
1996\end{array}$ & $\begin{array}{l}\text { Esse mundo } \\
\text { é todo seu }\end{array}$ & $\checkmark$ & $\checkmark$ & $\checkmark$ & $\checkmark$ & $\checkmark$ \\
\hline $\begin{array}{l}1996 \\
1996\end{array}$ & $\begin{array}{l}\text { Mundo on-line. } \\
\text { Globo e você tudo a ver }\end{array}$ & $\checkmark$ & $\checkmark$ & $\checkmark$ & $\checkmark$ & $\checkmark$ \\
\hline $\begin{array}{l}1997 \\
1997\end{array}$ & $\begin{array}{l}\text { Globo e você, } \\
\text { toda hora tudo a ver }\end{array}$ & $\checkmark$ & $\checkmark$ & $\checkmark$ & $\checkmark$ & $\checkmark$ \\
\hline $\begin{array}{l}1993 \\
1993\end{array}$ & $\begin{array}{l}\text { A Globo vira e mexe, } \\
\text { mexe com você }\end{array}$ & & $\checkmark$ & & $\checkmark$ & \\
\hline $\begin{array}{l}1996 \\
1997\end{array}$ & $\begin{array}{l}\text { A Globo } \\
\text { bola o que rola }\end{array}$ & $\checkmark$ & $\checkmark$ & $\checkmark$ & $\checkmark$ & \\
\hline $\begin{array}{l}1997 \\
1998\end{array}$ & $\begin{array}{l}\text { Quem tem Globo, } \\
\text { tem tudo }\end{array}$ & & & $\checkmark$ & $\checkmark$ & $\checkmark$ \\
\hline $\begin{array}{l}1998 \\
1998\end{array}$ & $\begin{array}{l}\text { Um caso de } \\
\text { amor com você }\end{array}$ & & $\checkmark$ & & & \\
\hline $\begin{array}{l}1998 \\
1998\end{array}$ & $\begin{array}{l}\text { Um caso de } \\
\text { amor com o Brasil }\end{array}$ & & $\checkmark$ & & & \\
\hline $\begin{array}{l}1999 \\
1999\end{array}$ & $\begin{array}{l}\text { Uma nova emoção } \\
\text { a cada dia }\end{array}$ & & $\checkmark$ & & $\checkmark$ & $\checkmark$ \\
\hline $\begin{array}{l}1999 \\
1999\end{array}$ & $\begin{array}{l}\text { Tá todo mundo } \\
\text { de olho na Globo }\end{array}$ & & $\checkmark$ & & $\checkmark$ & $\checkmark$ \\
\hline $\begin{array}{l}2000 \\
2000 \\
\end{array}$ & $\begin{array}{l}\text { Globo } 2000 \\
\text { no coração do Brasil }\end{array}$ & & $\checkmark$ & & $\checkmark$ & $\checkmark$ \\
\hline $\begin{array}{l}2000 \\
2000 \\
\end{array}$ & $\begin{array}{l}\text { Emoção } \\
\text { à vista }\end{array}$ & & $\checkmark$ & & $\checkmark$ & $\checkmark$ \\
\hline $\begin{array}{l}2001 \\
2000\end{array}$ & $\begin{array}{l}\text { A gente } \\
\text { se vê por aqui }\end{array}$ & $\checkmark$ & $\checkmark$ & & $\checkmark$ & $\checkmark$ \\
\hline $\begin{array}{l}2006 \\
2007\end{array}$ & $\begin{array}{l}\text { Só se vê } \\
\text { na Globo }\end{array}$ & $\checkmark$ & $\checkmark$ & & $\checkmark$ & $\checkmark$ \\
\hline $\begin{array}{l}2011 \\
2012\end{array}$ & $\begin{array}{l}\text { A gente } \\
\text { se liga em você }\end{array}$ & & $\checkmark$ & & $\checkmark$ & $\checkmark$ \\
\hline $\begin{array}{l}2014 \\
2014\end{array}$ & $\begin{array}{l}\text { A Globo está em movimento para } \\
\text { acompanhar a vida, o mundo e você }\end{array}$ & $\checkmark$ & $\checkmark$ & $\checkmark$ & $\checkmark$ & $\checkmark$ \\
\hline Total & & 15 & 25 & 8 & 26 & 20 \\
\hline
\end{tabular}




\subsubsection{Enunciação fundamental: mediação}

A função de mediação aparece nas vinhetas a partir, predominantemente, de duas explorações de sentido. A primeira aposta na valorização da instância da enunciação, destacando os agentes envolvidos nas diversas produções e a qualidade do trabalho realizado. De modo que algumas vinhetas tratam de revelar os bastidores da emissora e homenagear a equipe. Nesse sentido, pode-se citar "Essa gente que você não vê faz a TV que você vê" (1982/83), vinheta em que atores apresentam profissionais desconhecidos do grande público; "No pique da Globo e entre no ar" (1984/85), que expõe intensa e animada atividade de trabalho; também o jingle "A Globo 90 é nota 100" (1990), em que artistas da Globo comemoram o êxito alcançado pela emissora em relação à proposta de mediação e até "Só se vê na Globo"(2006/07), uma vez que a ideia de exclusividade em relação a determinados conteúdos pressupõe uma mediação diferenciada - melhor desenvolvimento e qualidade. Características que justificam slogans como "Agora mais um campeão de audiência"(1980/81) com a variante "Vem aí mais um campeão de audiência" (1980/81) e “O veículo de comunicação número 1 do país” (1985), já nos primeiros anos da emissora.

A segunda abordagem aposta na valorização dos conteúdos ofertados. Como exemplo, posso citar o slogan "O que pinta de novo, pinta na tela da Globo" (1985), que afirmava a sensibilidade da emissora para as mudanças e as tendências da época; e os slogans "Globo e você, tudo a ver" (1991/97) - com as variantes "Mundo on-line. Globo e você, tudo a ver" (1996) e "Globo e você, toda hora tudo a ver" (1997) e "Esse mundo é todo seu" (1996), que faziam sobressair a ampla cobertura realizada pela TV Globo. Ou seja, mensagens que exploravam a novidade e a pluralidade dos conteúdos transmitidos.

No final dos anos 90, entretanto, a coisa muda um pouco de figura. Com o slogan "A Globo bola o que rola" (1996/97) a emissora deixava de posicionar-se simplesmente como meio de veiculação para ser, ela mesma, a instância de criação das coisas, das tendências, das principais conversas - explorando um poder que ela já vinha exercendo sobre a sociedade desde o final da década de 70 .

Nesse sentido, com base nas pesquisas que fez sobre a Rede Globo, Dominique Wolton concluiu em $O$ elogio do grande público que apesar da lógica comercial ter impulsionado o crescimento da emissora "o seu sucesso provém, também, do fato de ter conseguido, em trinta anos, tornar-se ao mesmo tempo espelho e parte do ideal brasileiro. Portanto, em ter conseguido tanto refletir quanto estimular" (2006, p. 159). De fato. Em adição ao próprio slogan que considerei - "A Globo bola o que rola" -, dezenas de 
exemplos poderiam ser dados. Basta pensar nos bordões, nas tendências de vestuário e adereços que muitas novelas lançaram, e isso só para ficar no lado mais ameno dessa influência.

Mas o que chama realmente a atenção é a demora da Globo em explorar nas vinhetas institucionais a influência da televisão, o estímulo que causava em todos os segmentos. E por que o atraso? Por que um slogan como "A Globo bola o que rola" surge apenas em 1996? Acontece que concomitantemente à sua fase de expansão e consolidação, a televisão enfrentou um discurso intelectual duríssimo. Criticar a TV entre os anos 70 e 80 era praticamente um modismo e a queixa quase sempre a mesma: dominação, alienação. Dessa forma, embora a televisão realmente exercesse grande influência, querer utilizar isso de modo positivo poderia ser bastante arriscado na época, um verdadeiro tiro no pé.

Mas isso não põe fim à questão. Parte da resposta está também na própria obra de Wolton. A defesa que ele faz da televisão geralista surge justamente quando o reinado massivo dela começa a ser ameaçado pelos canais e programas segmentados. Apelar para o papel de estímulo, integração, lançamento de mitos, tendências e ideias que somente a televisão geralista podia realizar parece ser uma tentativa de reforçar um poder quase absoluto que começava a se extinguir, na ânsia de reter uma audiência que também passava a se dispersar.

Segundo os dados de Borelli e Priolli (2000), em 1993 o país contava com 250 mil assinantes de TV paga, número que se expandiu para 1 milhão em 1995, quando houve a regulamentação das atividades de produção, programação, empacotamento e distribuição dos conteúdos por meio da lei da TV a Cabo (lei ${ }^{\circ}$ 8.977). O slogan da Globo veio em 1996. Com se sabe, em 1997 o número dos assinantes chegou a 2,5 milhões e não foi muito além disso nos anos posteriores. Na época ninguém podia prever esse desempenho, e a Rede Globo fez sua campanha como pôde. Hoje, o número de lares atendidos pela televisão paga está na casa dos 12 milhões, e corresponde a cerca de $1 \%$ da população $\operatorname{apenas}^{29}$.

Além da TV paga, havia a preocupação com as outras emissoras abertas. Elas haviam entrado na onda da programação segmentada no início da década de 90 e os efeitos já começavam a ser sentidos. Para a concorrência, era mais fácil disputar fatias bem definidas da audiência que brigar com a Globo projetando um telespectador médio para

\footnotetext{
${ }^{29}$ Fonte: Estadao.com.br. Disponível em br.fiance.yahoo.com/noticias/TV-assinatura-atinge-12-2-estado2382716931.html? $\mathrm{x}=0$. Acesso em 28 de novembro de 2011.
} 
toda a programação. Foi assim que as televisões investiram em atrações direcionadas, e foi assim que a Rede Globo viu parte de seu público mudar de canal.

Para piorar as coisas para a Globo, a década de 90 foi também a época da popularização da internet - especialmente a partir de 1995, quando surgiu a figura do "provedor de rede" e as pessoas começaram a ter acesso discado à web. Aos poucos as pessoas foram migrando de um meio para o outro, e na passagem de telespectador para usuário os pontos de audiência foram caindo. Em meio a tudo isso, um slogan com "A Globo bola o que rola" (1996) parece até reivindicar para a emissora o seu lugar ao trono.

Por conta dessas ameaças, a Globo investiu durante toda a década de 90 na passionalidade do sujeito atrás da tela, buscando criar uma relação de afeto entre enunciador e enunciatário, como destacarei no próximo tópico. Todavia, as consequências da atuação da concorrência continuavam a reverberar na década seguinte. Nesse contexto surgem "A gente se vê por aqui" (2001), reafirmando ao enunciatário a proposta de visibilidade; também o slogan "Só se vê na Globo" (2006-2007), que apostava na exclusividade de alguns conteúdos; e "A Globo está em movimento para acompanhar a vida, o mundo e você" (2014), mensagem em que a atuação da emissora se revelava norteada pelas mesmas mudanças que envolviam o telespectador.

\subsubsection{Promessa: interação}

Assim como no caso anterior, a promessa de interação também resulta de diferentes construções estratégicas. A primeira que destaco é a realização de "mensagens-convite", incitando o público a participar. Isso acontece em slogans como: "No pique da Globo e entre no ar" (1984/85); "Vem que tem, na Globo tem" (1986/87); “Pega essa onda, essa onda pega" (1987/88). A segunda abordagem envolve demonstrar que muitos já aceitaram o convite feito, instigando o telespectador a não ficar de fora. "Agora, mais um campeão de audiência" (1980/81), "O veículo de comunicação número 1 do país" (1985), "A Globo pega pra valer" (1989), "A Globo bola o que rola" (1996/97) e "Tá todo mundo (1999) de olho na Globo" são exemplos claros nesse sentido, que tratam de revelar a aderência do público em geral.

E a terceira abordagem recorrente busca criar uma relação de afeto e cumplicidade entre enunciador e enunciatário. Ela aparece pela primeira vez em 1975 com o slogan "Hoje é juventude, 10 anos e aí estamos nós, caminhando com você", outra em 1982 com "Essa gente que você não vê faz a televisão que você vê", demonstrando o trabalho da 
emissora em prol do telespectador, e passa a se intensificar na década de 90 . Retomando essas produções, entre 1991 e 1997 o slogan "Globo e você, tudo a ver" - com as variantes "Mundo on-line. Globo e você, tudo a ver" e "Globo e você, toda hora tudo a ver" (1997) - era não apenas um anúncio, ou mesmo uma promessa de vasta e diversificada grade televisiva, mas também a celebração da completa sintonia entre a emissora e o telespectador. Em 1993, o slogan "A Globo vira e mexe, mexe com você" tornava claro o empenho da emissora em transformar-se ("vira e mexe" com sentido de "modificar-se"), constantemente ("vira e mexe" para dizer "de tempos em tempos"), para agradar ao público, despertar seu interesse e emocioná-lo (“mexe com você"). Em 1996, o slogan "Esse mundo é todo seu" também mostra o empenho da emissora nesse sentido, presenteando o telespectador com uma programação feita especialmente para ele. Em 1998, com "Um caso de amor com você" e a variante "Um caso de amor com o Brasil" (lembrando que era ano de Copa do Mundo), estava decretado o relacionamento amoroso.

Apesar disso, não se pode dizer que a coisa seguia os moldes tradicionais. A palavra "caso", que traz o sentido de uma aventura amorosa, afasta a ideia de rotina, monotonia e obrigação. Livre, sem compromisso, o telespectador podia usufruir um prazer de amante - ou como quer o slogan de 1999, "Uma nova emoção a cada dia".

A emissora estava de olho no futuro - "Globo 2000, no coração do Brasil" (1999) e com o slogan "emoção à vista" (1999) continuava explorando o que parecia ser o ponto fraco do telespectador, o prazer visual. $\mathrm{O}$ encontro fortuito - longe da necessidade de se estar em determinado lugar e horário com data marcada - permanece em 2001 com o slogan "A gente se vê por aqui". Embora "a gente" da frase possa compreender "os outros" (toda a gente, por exemplo), pode ser também "nós" (público individualizado e emissora). A expressão, pra lá de descompromissada e ao mesmo tempo confiante no forte vínculo estabelecido, parecia mesmo confirmar os versos de Camões - amar é querer estar preso por vontade.

Se a criação dos slogans retratam em certo sentido as etapas de um envolvimento amoroso - primeiro com a identificação de coisas em comum, a completa sintonia ("tudo a ver"); depois pela percepção da sensibilização ("mexe com você"), e por fim o reconhecimento de um verdadeiro laço afetivo, mesmo que descompromissado ("um caso de amor", “a gente se vê por aqui”) - em 2006, sentindo o desinteresse por parte do telespectador, a emissora apela para a exclusividade dos conteúdos que oferece - "Só se vê na Globo". 
Vinte anos após a primeira declaração de amor, a emissora renova os votos com a campanha "Agente se liga em você". O teor da mensagem narrada é de envolvimento e revela uma convivência de longa data. Todavia, a expressão evidencia mais que os outros slogans uma postura que foi se firmando desde o início da década de 90, com a queda da audiência. Como o público - seduzido por outros canais de TV e pela internet - passou a não se ligar como antes na Globo, a emissora teve que correr atrás e "se ligar no telespectador", por assim dizer. Desde então, não é mais o público que procura pela emissora, mas a emissora que procura pelo público, oferecendo a ele exatamente o que "ele quer", conforme o slogan de 2014: "A Globo está em movimento para acompanhara vida, o mundo e você”".

\subsubsection{Especificação da promessa: âmbito global}

A abordagem estratégica neste caso está em se aproveitar de termos e expressões generalistas. Slogans como "O que pinta de novo, pinta na tela da Globo” (1985); "Globo e você, tudo a ver" (1991/97) e "Quem tem Globo, tem tudo" (1997/98) são construídos dessa forma. Quando a emissora afirma, por exemplo, veicular o que surge de "novo" a proposta não está restrita a territórios específicos; da mesma forma, a palavra "tudo" faz referência ao conjunto de todas as coisas - quer sejam pessoas, fatos, eventos e assim por diante - independentemente do lugar em que estes estão ou ocorrem.

De maneira mais explícita, utiliza-se em algumas mensagens a palavra "mundo", como no slogan "Esse mundo é todo seu" (1996), no sentido de uma programação ampla, totalizante, feita especialmente para o telespectador, dando a ele livre acesso a todas as coisas; e "Mundo on-line. Globo e você, tudo a ver" (1997/98), em que a referência aponta para o mais globalizado de todos os territórios, a internet. Até o slogan "A Globo bola o que rola" (1996/97) evoca a esfericidade do planeta e a ideia de mundo que apresentei nos slogans anteriores, pautando as criações que realiza e a influência que elas obtêm num nível global. Por fim, a mensagem "A Globo está em movimento para acompanhar a vida, o mundo e você" (2014) deixa evidente que as mudanças que acometem o telespectador e, consequentemente, a emissora fazem parte de uma mudança de padrão vivenciada no mundo todo, não apenas em territórios específicos.

O fato de a emissora não restringir sua atuação aos limites geográficos do país não quer dizer que estes não ganhem, vez por outra, algum destaque - até porque especificar a promessa em termos globais envolve, evidentemente, retratar o que acontece em âmbito 
nacional também. Todavia, vinhetas com projeções desse tipo despontam sempre em contextos muito específicos - como a comemoração de avanços da mídia em território nacional ("O veículo de comunicação número 1 do país), ou ano de Copa do Mundo ("Um caso de amor com o Brasil"). Como se pode ver, são situações pontuais em que o verdadeiro foco da mensagem não está sobre o âmbito nacional de atuação da emissora, mas em aspectos como a interação enunciador-enunciatário e próprio meio televisivo, respectivamente. E, portanto, são construções que não enfraquecem a especificação da promessa de interação em âmbito global.

\subsubsection{Território: televisão}

A abordagem em torno da televisão como território se dá nos slogans de duas maneiras. A primeira é pela projeção da própria enunciação - "nós”, “a gente”, "a Globo" - e a segunda é por fazer referências ao meio - quer em relação à configuração do público ("audiência"), suporte ("veículo"), tecnologia e transmissão de sinal ("no ar", "liga", "onda", "pega"), programação ("esse mundo", "a cada dia”) ou dispositivo visual (“televisão", "ver”, “olho”, “à vista”) - conforme os slogans: “Agora mais um campeão de audiência"(1980/81); "Vem aí mais um campeão de audiência"(1980/81); "Essa gente que você não vê, faz a televisão que você vê" (1982-83); "No pique da Globo, e entre no Ar" (1984-85); "O que pinta de novo, pinta na tela da Globo" (1985); "O veículo de comunicação número 1 do país" (1985); "Vem que tem, na Globo tem" (1986-87); "Pega essa onda, essa onda pega" (1987-88); “A Globo pega pra valer" (1989); “A Globo 90 é nota 100" (1989-90); “Globo e você, tudo a ver" (1991-97); (1996); "Mundo on-line. Globo e você tudo a ver"(1993); "A Globo vira e mexe, mexe com você"; "Globo e você, toda hora tudo a ver" (1997); "Esse mundo é todo seu" (1996); “A Globo bola o que rola" (1996-97); "Quem tem Globo, tem tudo" (1997-98); "Uma nova emoção a cada dia" (1999); "Tá todo mundo de olho na Globo" (1999); "Globo 2000, no coração do Brasil" (1999-2000); "Emoção à vista" (2000); "A gente se vê por aqui" (2001); "Só se vê na Globo" (2006-07); "A gente se liga em você" (2011-12); “A Globo está em movimento para acompanhar a vida, o mundo e você" (2014).

\subsubsection{Valores: tecnologia e pluralidade}

A questão técnica em torno da televisão é uma abordagem presente em toda a década de 80. "No pique da Globo e entre no ar" (1984/85), "Pega essa onda, essa onda 
pega" (1987/88) e "A Globo pega pra valer" (1989) faz lembrar uma época em que se colocava lã de aço nas antenas de televisão para captar melhor o sinal. Enquanto a imagem chuviscava ou criava fantasmas nos outros canais, o sinal da Globo era limpo e chegava a lugares em que os outros não chegavam. Em termos contextuais, vale lembrar que a transmissão via satélite - bem mais confiável que o sistema anterior de micro-ondas havia surgido em 1981. A Globo aderiu logo ao novo sistema, mais exatamente em 1982, e passou a bater forte nos slogans de valorização de seu aparato tecnológico.

$\mathrm{Na}$ década seguinte, a internet começou a se popularizar por conta da figura do provedor de rede, que surgiu em 1995, dando acesso discado à rede. Em vista disso, a emissora lança no ano seguinte o primeiro portal da Globo. Naquela época um único site abrigava toda a informação virtual da emissora, com ênfase nas notícias jornalísticas e esportivas. Havia também um ícone para a apresentação da empresa e outro para a programação da semana. Como a televisão estava "agora também na internet", como se exibia na homepage, o slogan da vez ganhou uma variante nesse ano: "Mundo on-line. Globo e você, tudo a ver" (1996).

Apesar de menos evidente, a questão tecnológica reaparece no final da década de 90. Com os slogans "Uma nova emoção a cada dia" (1999) e "Emoção à vista" (2000) a Rede Globo sinalizava para o novo milênio não somente a produção de conteúdos televisivos capazes de emocionar ainda mais o público, mas, sobretudo, a chegada de avanços técnicos para a televisão que atingiriam em cheio a sensibilidade do telespectador.

A promessa contida nos slogans é de uma experiência sensível que se renovaria dia a dia, marcando o início de uma nova era em que o público seria encantado pelas visões da TV. E, de fato, nos anos que se seguiram, muitos dispositivos técnicos que garantiam alta qualidade de imagem foram lançados. Os televisores com tubos de raios catódicos, por exemplo, deixaram de ser produzidos e deram lugar a aparelhos de plasma e cristal líquido com imagem em alta definição. Além de cansar menos a vista e apresentar uma excepcional reprodução de cores, as telas desses monitores eram realmente planas e por isso eliminavam as distorções de imagem comuns nos monitores de tubos. Os televisores, que na década de 90 foram ficando cada vez menores e mais portáteis, começaram a aumentar de tamanho e a se estabilizar nos móveis e também nas paredes das casas. Nesse processo, o padrão 4:3 da tela deu lugar ao formato 16:9, típico do cinema. Por fim, a onda de desenvolvimentos tecnológicos culminou realmente com uma mudança significativa em 
termos de produção e recepção, que foi a TV digital, lançada oficialmente no Brasil em 2007 com a promessa de interatividade.

Em relação ao valor de pluralidade, as abordagens oscilam estrategicamente entre a exploração da audiência conquistada, como nos slogans "Agora mais um campeão de audiência" (1980/81)/“Vem aí mais um campeão de audiência" (1980/81) e "Tá todo mundo de olho na Globo" (1999), no sentido de exprimir a totalidade do público incluindo a concorrência, que fica "de olho" no fazer-televisivo da Globo - e a exploração dos conteúdos ofertados, conforme as necessidades contextuais. O objetivo é valorizar a pluralidade da grade, a fim de trazer para a frente da tela todo tipo de telespectador: homens, mulheres, jovens, idosos, crianças etc.

Nesse sentido, pode-se observar que as datas dos slogans que comemoram o primeiro lugar nas pesquisas correspondem aos anos de consolidação da TV Globo e se estendem até o final dos anos 90, a partir de quando se torna difícil falar em hegemonia. Para dar uma ideia do que isso significa, "se em 1993, a emissora possuía 68\% de participação na audiência, esse índice cai, para uma faixa em torno de 56 e $57 \%$ em 1997 e 1998, respectivamente (BORELLI; PRIOLLI, 2000, p. 161). Com isso, slogans que valorizavam os conteúdos da emissora como "Vem que tem, na Globo tem”, de 1986/87, passam a se intensificar gradativamente. Vendo que os outros canais abertos focavam em propostas muito particulares em termos de programação, por causa do processo de segmentação que se desenvolvia com as televisões pagas, a Globo resolveu explorar sua diversificada grade e chamou para si não um público específico, mas todos os diferentes segmentos com os slogans "Globo e você, tudo a ver" (1991/97); "Globo e você, toda hora tudo a ver" (1991/97); "Quem tem Globo tem tudo" (1997). E depois disso apostou na exclusividade de alguns conteúdos lançando "Só se vê na Globo" (2006). Vale lembrar que era ano de Copa do Mundo e a Globo transmitiu sozinha os jogos na TV aberta.

\subsubsection{Ruídos}

O ruído quase sempre é tomado como um som indesejado, desagradável e perturbador. No âmbito da televisão, basta lembrar o barulho incômodo dos chuviscos que marcaram as primeiras décadas do aparelho. Mas como isso é coisa do passado, considerando, especialmente, que na televisão com sinal digital o chiado não existe - ou a imagem funciona perfeitamente ou então não funcionada de maneira alguma - é preciso ir adiante para entender a importância dos ruídos na criação de uma estética audiovisual. 
O primeiro passo segue em direção ao reconhecimento do ruído como um possível elemento de identidade sonora, como já adiantei em outras partes deste capítulo ao citar, por exemplo, o papel autorreferencial desempenhado pelo "plim-plim" da Globo. Mas as funções desse recurso vão além. Basta lembrar as razões pela qual foi criado:

\begin{abstract}
Na televisão, me incomodava a inserção de um intervalo comercial em um filme de longametragem, que havia sido produzido para ser exibido no cinema, sem interrupção. Os montadores das emissoras de televisão, pensando que estavam prestando algum serviço à empresa, escolhiam os momentos mais emocionantes, ou o auge da ação, para interromper o filme, deixando o telespectador irritado com a emissora e com ódio do anunciante. Resolvi separar os filmes dos comerciais e mandei bala (...) Com o Borjalo, criei uma vinheta, ainda em preto e branco, com um diafragma que se fechava para entrar os comerciais e depois se abria para voltar ao filme (OLIVEIRA SOBRINHO, 2011, p. 300).
\end{abstract}

O diafragma do qual nos fala Oliveira Sobrinho era acompanhado nas vinhetas por um "bib-bib", que simbolizava o abrir e fechar de um obturador. Portanto, o ruído acompanhava a figura e o movimento, dando à imagem que aparecia na tela certo realismo, ritmo e força. Como diz Xavier (2008, p. 36) "tornar audível o que já está sendo visto é uma forma de torná-lo mais convincente". Quando a logomarca foi renovada por Hans Donner o aspecto platinado da Globo exigiu um som mais estridente, que simulasse o toque do metal e não mais o da câmera, como explica o ex-diretor:

Na era Hans Donner, quando ele propôs uma
nova vinheta, percebi que o "bip-bip" não
combinava com a modernidade dele e não tinha
personalidade para marcar a Globo. Imaginei
que o som deveria ser eletrônico e
característico. Ouvi dezenas de opções e, enfim,
escolhi o que foi proposto pelo músico Luzi
Paulo Simas. O 'plim, plim' pegou, ajudou a
definir o que era filme e o que era comercial e
ainda virou uma marca da Globo (IBIDEM).

Com isso, não se pode deixar de destacar o efeito de realidade que os ruídos podem conferir às imagens na televisão, especialmente se forem imagens simuladas, como 
frequentemente acontece no caso das vinhetas. E há um aspecto bastante curioso nesse sentido. Sabe-se que em qualquer obra audiovisual há basicamente apenas dois tipos de som: os que estão dentro e os que estão fora de quadro. Em outros termos, os sons diegéticos e os não-diegéticos.

A música e o spot publicitário, que vimos até agora, são normalmente trabalhados de modo não-diegéticos. Já os jingles oscilam entre o diegético e o não-diegético, aparecendo algumas vezes dentro e outras fora de cena. Como alguns deles possuem fortes marcas de pessoalidade (como, por exemplo, na frase: "a Globo é a gente quem faz") é comum aparecer artistas da emissora cantando a letra enquanto o vídeo se desenrola. Mas como isso não é uma regra, alguns são simplesmente cantados por locutores externos, fora do quadro. Os ruídos, no entanto, são sempre diegéticos nas vinhetas.

Eles aparecem de modo sincronizado com as imagens e chegam a criar sensações sinestésicas no telespectador. Quando se tem a percepção de uma sensação a partir de um determinado órgão do sentido, mas ela é, na verdade, devida ou reforçada por um estímulo em outro órgão, o que se tem é justamente sinestesia. E é o que acontece com mais frequência em relação aos ruídos. Isso porque, nas vinhetas, imagem e som tendem a se reforçar mutuamente - como imagens que pulsam na tela acompanhadas por batidas sonoras, movimentos de zoom out acompanhados por tons contínuos e cada vez mais agudos, e assim por diante. Extensão, altura, profundidade, densidade, velocidade, pausa e impacto são apenas algumas das noções que se pode expressar com a ajuda do som.

No caso dos videografismos, o uso de ruídos para efeito de realidade se torna ainda mais complexo porque certas imagens podem chegar a um grau zero de semelhança com o mundo natural. As vinhetas da televisão já foram feitas em moldes figurativos à base de cartolina e videotape, mas hoje são feitas a partir de códigos binários, num tipo de representação que simplesmente dispensa a necessidade de qualquer objeto preexistente ${ }^{30}$. Como as imagens passam a ser artificiais e não mais naturais, podendo com isso não só passar do figurativo ao abstrato com grande expressividade, mas, também, criar narrativas alheias às leis que regem o mundo natural, o som que acompanha a ação precisa ser igualmente criativo. E, muitas vezes, ficará a cargo do ruído gerar para a representação o sentido de correspondência que o telespectador precisa para aceitar a peça audiovisual.

\footnotetext{
${ }^{30}$ Cf. Apêndice I - Vinheta de TV: tipos, usos e funções.
} 


\subsubsection{Relações audiovisuais}

Estive concentrada até aqui em apresentar as formas de uso e sentido de diversos recursos sonoros - músicas, jingles, spots e ruídos - presentes nas vinhetas institucionais da Rede Globo. A partir de agora, no entanto, darei atenção para os dilemas de sentido que podem surgir quando esses recursos são deslocados para composições diferentes daquela para a qual foram originalmente criados.

Embora a música de determinada peça possa se desvincular de sua respectiva imagem e o árduo trabalho de um sound designer se perder, por exemplo, em ruídos que em nada se relacionam com o novo videografismo em que foram encaixados, o elemento que mais migra entre as vinhetas e é mais facilmente percebido pelo telespectador é o slogan - que normalmente aparece em forma de spot.

O que acontece é que apesar dos slogans da Rede Globo serem concisos, fáceis de entender e de memorizar não raras vezes são também ambíguos, permitindo leituras polissêmicas. Daí o uso multiplicado. Dessa forma, alguns deles são projetados em videografismos que nem sempre pertencem a uma mesma série; e o oposto também ocorre: um único videografismo pode funcionar como pano de fundo para os mais variados slogans. Se os textos correm por diversas imagens e as imagens com diversos textos - em alguns casos, até de modo aparentemente aleatório -, o que se pode esperar das relações entre texto e imagem nessas produções? Afinal de contas, a ambiguidade dos slogans se resolve ou se prolonga na imagem do vídeo? Em que medida a alteração de uma imagem interfere no significado do slogan, e a alteração do slogan no sentido da imagem? Veremos alguns exemplos.

Antes disso, no entanto, é preciso esclarecer o que são as "séries" ou "campanhas" das quais falarei, já que é nesse tipo de produção que mais se observa deslocamentos de som e imagem. As vinhetas de séries ou campanhas constituem-se produções que têm por base um mesmo slogan, seja ele falado ou escrito. Basta dar uma olhada na listagem cronológica das mensagens institucionais que levantei anteriormente para ver que a Rede Globo tem trabalhado sistematicamente dessa forma. Alguns slogans, inclusive, chegam a ficar anos no ar.

Como nesse tipo de produção os recursos audiovisuais normalmente ilustram a mensagem, as séries costumam seguir dois padrões: ou reforçam um mesmo conceito, repetindo a forma de abordagem; ou buscam apresentar os diferentes aspectos que o conceito pode oferecer, mudando o padrão de apresentação. 
No primeiro caso, a estratégia tende sempre a diminuir as incertezas. Se o texto verbal lança dúvida na cabeça do telespectador, a imagem e o som põe fim a qualquer interpretação não intencionada por enfatizar a verdadeira ideia que norteia o tema. É o que acontece com as vinhetas da série "A gente se vê por aqui" ${ }^{31}$ ". Em situação anterior, cheguei a abordar a mensagem a partir da estratégia do "envolvimento amoroso" - e, mais especificamente, do "encontro casual" - que pode ser percebida numa análise diacrônica dos slogans da emissora. Mas o sentido mais evidente do texto é que as pessoas podem ver a si próprias por meio da televisão, quer dizer, seus contextos de vida e lugares de referência. As duas alternativas são interessantes para uso institucional, explorando, inclusive, a mesma promessa de interação. Mas, nesse caso, a Rede Globo fez questão de direcionar o público: colocou na tela lugares de todos os cantos do país e o som típico de cada região. A linguagem verbal escrita, falada e também a musical se complementaram e o telespectador pôde sentir na mensagem que a emissora estava bem perto dele, porque a sua própria vida também era tema da televisão.

O interessante é que as vinhetas com esse slogan não repetiam só a mesma ideia, repetiam também a forma. Em todas há o mesmo tipo de captação aérea de imagem, o mesmo movimento de aproximação de câmera e o mesmo comportamento sonoro. Seria isso apenas um capricho audiovisual? Não. Nesse caso, é a igualdade da forma que garante a igualdade do conteúdo. Qualquer coisa diferente disso transmitiria uma postura de parcialidade em relação às regiões que não convém a uma emissora do tipo broadcast. É por isso, para garantir uma suposta visibilidade do país como um todo, que a Globo investiu tanto na repetição do conceito como também da forma.

No segundo caso, o da exploração dos múltiplos sentidos do texto, a estratégia é aproveitar todas as brechas. Um slogan que ilustra isso é "Globo e você, tudo a ver". Esse texto apareceu em diversas vinhetas na década de 90 e deu margem a pelo menos cinco explorações de sentido. A primeira delas fica por conta da metáfora que se estabelece entre o olho humano, a objetiva de uma câmera e a própria logomarca da Rede Globo. Uma mensagem focada, portanto, na ação do sujeito - quem vê e como vể $\hat{e}^{32}$.

Numa segunda abordagem o que ganha destaque é o objeto do olhar, o que é visto pelo telespectador. Do centro da logomarca da emissora saem figuras que conseguem

\footnotetext{
${ }^{31}$ Vinhetas da série disponíveis em: http://www.youtube.com/watch?v=jckba0BO2w8;http://www.youtube.com/watch?v=EPwVdv8AkhU http://www.youtube.com/watch?v=pQfqwDGi4LQ; http://www.youtube.com/watch?v=HmpU9dfqlDs ${ }^{32}$ Disponível em: http://www.youtube.com/watch?v=TmvkmB0Lrv0
} 
representar com facilidade alguns dos principais conteúdos da televisão - coisas como um carro de esporte, um instrumento musical, um rolo de filme e assim por diante ${ }^{33}$.

Um terceiro tipo de peça foca não o sujeito que vê ou o objeto que é visto, mas o lugar em que está o conteúdo. Foi para apresentar o site da Globo, criado em 1996, que a emissora lançou a variação "Mundo online: Globo e você, tudo a ver" ${ }^{34}$. Hoje são dezenas de portais. Cada programa tem o seu próprio endereço na rede e as páginas possuem diversificados recursos multimídia, mas naquela época a emissora tinha um único site e todo o conteúdo estava nele.

Por fim, esse slogan também foi empregado num videografismo que, trazendo a imagem de diversas antenas de televisão, colocava em evidência a tecnologia da emissora em termos de envio e recepção de $\operatorname{sinal}^{35}$. Enquanto nas outras emissoras o conteúdo falhava, na Globo o telespectador tinha "tudo a ver", quer dizer, a veiculação do conteúdo de toda a programação estava tecnologicamente assegurada.

Aproveitando, a variante "Globo e você, toda hora tudo a ver" inspirada no relógio Time Dimension, criado por Hans Donner, focava não só o contínuo conteúdo ofertado, mas a precisão do tempo, do horário de exibição desses conteúdos pontualidade que até hoje ainda não se resolveu em muitas emissoras.

Até aqui tudo bem. Mas, curiosamente, uma das últimas imagens citadas - a das antenas de TV - também funcionou como pano de fundo para outro slogan. Trata-se da mensagem "A globo vira e mexe, mexe com você"”37. Aparentemente, não há qualquer relação de sentido entre o texto e a peça audiovisual. Diferente do que acontece nos exemplos anteriores, a ambiguidade do slogan não é resolvida nem explorada pelas figuras e/ou pela música. Sinal de desordem?

Neste caso, não. O que parece ser aleatório e sem sentido funciona, na verdade, como elemento agregador e, às vezes, de transição. Basta lembrar que o slogan "Globo e você, tudo a ver" persistiu no ar entre 1991 e 1997, e que nesse meio tempo, mais precisamente em 1993, outro slogan também despontou: justamente o texto "A Globo vira e mexe, mexe com você". Posteriormente, entre 1996 e 1997, o processo se repetiu. Mas dessa vez quem forneceu o cenário audiovisual foi a nova vinheta. A metáfora da criação

\footnotetext{
${ }^{33}$ Disponível em: http://www.youtube.com/watch?v=9x28yurY1JI\&feature=youtu.be

${ }^{34}$ Disponível em: http://www.youtube.com/watch?v=kfbbcj95cBA\&feature=youtu.be

${ }^{35}$ Disponível em: https://www.youtube.com/watch?v=WSHFVvyc9N0

${ }^{36}$ Disponível em: http://www.youtube.com/watch? $\mathrm{v}=\mathrm{rBC} 6 \mathrm{Kq} 8 \mathrm{kFHI} \&$ feature=youtu.be

${ }^{37}$ Disponível em: http://www.youtube.com/watch?v=OuddYaJvf90\&feature=youtu.be
} 
do universo, própria do slogan "A globo bola o que rola"38, carregou por vezes o slogan "Globo e você, tudo a ver". E, na sequência, foi pano de fundo também para o slogan “Quem tem Globo, tem tudo",39, veiculado entre 1997 e 1998.

Com base nessas referências, o "empréstimo" audiovisual parece ser mais uma ação de estratégia do que de descuido. Especialmente porque permite à nova produção gozar das conquistas da anterior - em síntese, a boa aceitação do público. Uma nova mensagem, portanto, raramente chega de surpresa, como um elemento totalmente novo ou estranho. Antes, vai se colocando aos poucos, bem devagarinho, aproveitando elementos de áudio e vídeo já familiares ao telespectador.

Todavia, quando há uma mudança de enfoque, mesmo dentro de uma mesma proposta de abordagem - como as que apresentei anteriormente ao confrontar os slogans da emissora com os cinco eixos que sustentam o projeto identitário da marca - a coisa muda de figura. Esse aspecto pode ser ilustrado, por exemplo, com base nos valores da marca - mais precisamente na mudança de ênfase que se deu em 2014, na qual a tecnologia deu lugar à pluralidade. Dada a alteração de padrão proposta, uma vinheta como “A Globo está em movimento para acompanhar a vida, o mundo e você" não permite transições como as que apontei - emprestando recursos audiovisuais e pegando emprestado de outras produções. Nem comporta um modelo agregador com peças anteriores. Antes, exige ruptura estética. E, nesses casos, não se observa deslocamento audiovisual ou dilemas de sentido.

\section{Considerações preliminares}

De acordo com Greimas e Courtés, “a integração da problemática da verdade no interior do discurso enunciado pode ser interpretada, em primeiro lugar, como a inscrição (e a leitura) das marcas da veridicção, graças às quais o discurso-enunciado se ostenta como verdadeiro ou falso, mentiroso ou secreto" (1983, p. 486). Nesta segunda parte do capítulo, busquei apresentar como quatro recursos sonoros - música, jingle, spot e ruído costumam ser utilizados pela Rede Globo no intuito de criar diferentes efeitos de sentido. Dentre eles, o de veridicção.

Retomando o emprego dos recursos mencionados de maneira mais direcionada, vimos, por exemplo, que a música é comumente usada para criar uma atmosfera sensível,

\footnotetext{
${ }^{38}$ Disponível em: https://www.youtube.com/watch?v=y0e5i4xA_FM

${ }^{39}$ Disponível em: https://www.youtube.com/watch?v=aq28ScvUtJE
} 
uma ambientação contextual - o que acontece também com os jingles, que se desenvolvem a partir de uma dada musicalidade. Embora a aparição destes últimos possa oscilar entre o diegético e o não-diegético, o mais comum na Globo é que encontrem referências no quadro, quer dizer, que se originem dele e não de uma fonte externa - o que se torna uma regra no caso dos ruídos, que acompanham e dão vida aos elementos na tela. De uma maneira ou de outra, todas essas atuações sonoras reforçam o conteúdo das cenas propostas, contribuindo para a construção de um "todo" cuja coerência é capaz de forjar para o discurso certo "efeito de verdade".

Também quero chamar a atenção para a construção dos jingles e dos spots institucionais. Em termos de conteúdo, a análise diacrônica deixa evidente que além de explorarem os eixos sobre os quais se conforma o projeto identitário da marca, os slogans utilizados nas vinhetas retomam, de certa forma, a própria história da Rede Globo, sua trajetória como emissora - incluindo os "altos" e "baixos" de sua existência. Novamente, não se trata de deliberar sobre a "verdade" do discurso, mas considerar por meio das "marcas de veridicção" espalhadas no texto o "efeito de verdade" que ele promove.

Esse efeito chega a se ancorar em projeções temporais ("Globo 90" e "Globo 2000”), espaciais (“aqui”, "Brasil”, “país, “mundo”) e actorias (“nós”, “a gente”, “a Globo", "você"). Mas isso seria pouco se a "trajetória" ou "história" que se pretende apresentar não tivesse aquilo que a semiótica considera como o mínimo necessário para haver qualquer tipo de narrativa: ação. Quer dizer, um enunciado de fazer regendo um enunciado de estado. Tendo em vista que, neste caso, a proposta identitária da emissora engendra uma visada diacrônica - sobretudo porque "uma marca de prestígio é, antes de tudo, uma marca que sabe perenizar seu projeto e perdurar no tempo" (Semprini, 2006, p. 118) - ela simplesmente não admite a existência de um único ou estanque programa narrativo. Mas, requisita sucessivas tomadas de posição.

Isso não somente ocorre nas peças analisadas, como - outra vez - se dá de maneira coerente, pois as "tomadas de posição" se articulam sempre em torno dos elementos que estabelecem o projeto da marca. De modo que não se contradizem. Antes, se reforçam. Além disso, como pude explicitar em base metodológica na primeira parte do capítulo, embora essas "tomadas de posição" visem os mesmos elementos do projeto - enunciação fundamental (mediação), promessa (interação), especificação da promessa (global), território (televisão) e valores (tecnologia, pluralidade) - a abordagem varia de modo a explorar diferentes nuanças de sentido. Tal caráter original contribui para a valorização de 
cada item do projeto, reforçando, por assim dizer, a argumentação. E, sobretudo, deve-se notar que tais explorações acenam para oscilações contextuais que o telespectador é capaz de reconhecer como "existentes", "reais" e, portanto, "verdadeiras" - funcionando, portanto, como "ilusões referenciais". A emissora poderia investir em abordagens alheias às flutuações da sociedade, do público, da concorrência e assim por diante. Mas isso resultaria numa identidade "desconectada" do "mundo de verdade" que o telespectador sabe que existe. E, portanto, falseada, puramente abstrata, com poucas chances de convencer o telespectador. Essas diferentes modalidades veridictórias podem ser melhor percebidas na relação que se estabelece entre o "ser" e o "parecer" das coisas:

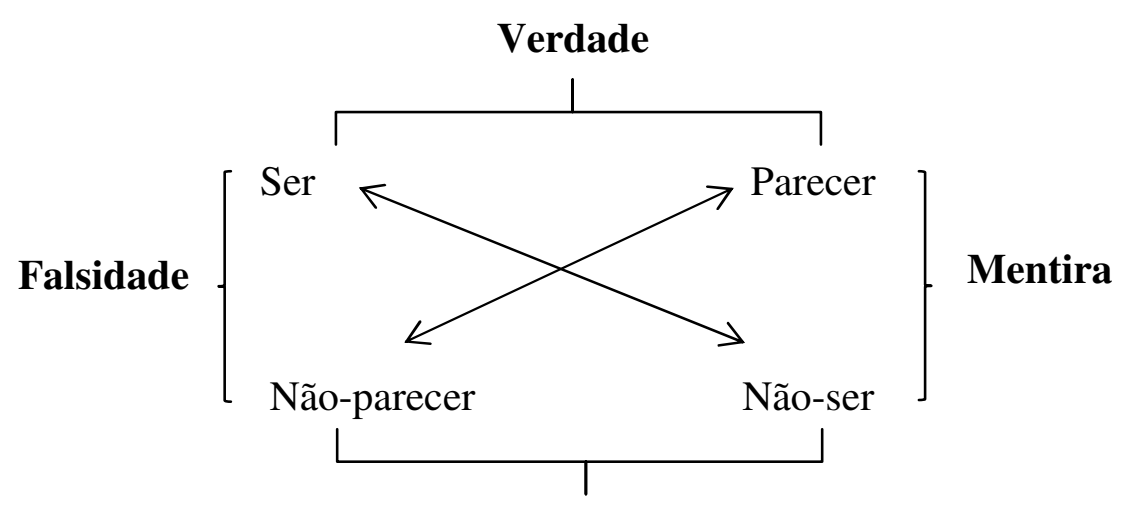

Falsidade

Tem-se no esquema anterior duas dimensões. Uma referente ao plano da imanência, pautado pela relação "ser/não ser", e outra referente ao plano da manifestação, pautado na relação "parecer/não-parecer". Conforme definem Greimas e Courtés, “a categoria da veridicção apresenta-se, assim, como o quadro em cujo interior se exerce a atividade cognitiva de natureza epistêmica que, com o auxílio de diferentes programas modais, visa a atingir uma posição veridictória, suscetível de ser sancionada por um juízo epistêmico definitivo" (1983, p. 488). No caso da identidade que a emissora propõe, é com base nas manifestações da marca (parecer/não parecer) que o enunciatário decidirá acerca de seu caráter imanente (ser/não ser). Daí a preocupação em disseminar nas vinhetas todas as "marcas veridictórias" que citei até aqui: ancoragens temporais, espaciais, temporais; coerência do discurso; argumentações originais; e ilusões referenciais.

Além dessas estratégias, quero ainda chamar a atenção sobre um último aspecto a respeito das construções sonoras das vinhetas. Como mencionei no decorrer desta segunda parte do capítulo, os slogans - que buscam resumir ou condensar a identidade da emissora 
- são veiculados, principalmente, na forma de spots. Ou seja, uma locução breve, composta por uma ou mais vozes. O ponto que quero destacar é que, em geral, a voz que narra não está no quadro. Não é diegética. Como uma "voz sem corpo" - “desencarnada”, por assim dizer -, não se dota da "pessoalidade" que uma figura enquadrada é capaz de criar, nem da "parcialidade" que a participação nos eventos poderia talvez implicar. O que, a princípio, instituiria um forte sentido de impessoalidade.

Todavia, a voz, em si, é não somente percebida como um componente humano sentido que se reforça pela verbalização que exibe e até mesmo por certas entonações, que traduzem sentimentos humanos - como tende a ser reconhecida - às vezes, por estabelecer ligação com sujeitos que o enunciatário está acostumado a ver e sabe, pelas características da voz, de quem se trata; às vezes por repetição, por ser sempre a mesma voz a abordar o enunciatário, tornando-se familiar aos seus ouvidos, de modo que ele pode reconhecê-la apesar de não saber, eventualmente, a quem ela pertence -, configurando um sentido de não-impessoalidade. Para melhor expor essa construção estratégica, colocarei os termos que a envolvem num quadrado semiótico:

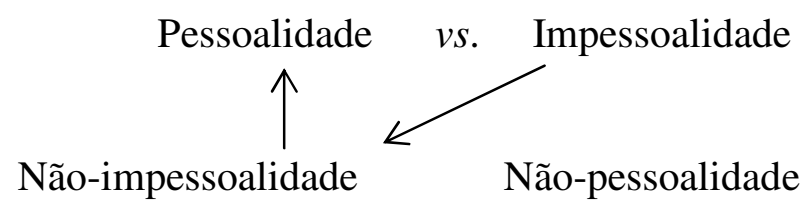

Como se pode deduzir - por não haver a aparição do portador da voz nos vídeos - a direção ou sentido apontado no quadrado não se completa, estagnando-se na "nãoimpessoalidade". Essa tomada estratégica permite à emissora lançar discursos sobre si própria com grande efeito de imparcialidade. Tendo em vista que o narrador da vinheta institucional muitas vezes é ou se torna um sujeito em quem o enunciatário confia - não só pela familiaridade que exibe ou constrói, mas também por seu caráter onisciente, uma vez que o narrador, mesmo sem fazer parte dos eventos de dentro do quadro, sabe tudo o que se desenrola neles, e até o que ainda vai acontecer - tal "imparcialidade" comumente não chega, sequer, a ser questionada. 


\section{Capítulo 3 \\ Da comunicação ao produto}

No primeiro capítulo deste trabalho tratei de apresentar as bases conceituais que fundamentam o projeto da Rede Globo como emissora de televisão. No segundo, busquei demonstrar como as vinhetas institucionais, acionando diferentes linguagens, retomam e dão concretude a tais pressupostos. Neste terceiro e último capítulo a análise recairá sobre a dimensão do produto. A ideia é avaliar a relação que os conteúdos veiculados mantêm com o projeto identitário e, especialmente, a coerência que estabelecem com as manifestações da marca no âmbito da comunicação. Ou seja, se o que a emissora oferta em sua grade é compatível com o que anuncia em sua propaganda, tendo em vista que desta performance depende a sanção do enunciatário. Então, vejamos item por item.

\begin{tabular}{ccc} 
Contrato & & Sanção \\
\hline & Competência & Performance
\end{tabular}

\subsection{O Contrato}

O contrato proposto pela Rede Globo - como apontei no primeiro capítulo - gira em torno de mediação. Envolve intensa interação entre enunciador e enunciatário. Possui abrangência global. Desenvolve-se pela televisão. E se sustenta sobre valores como tecnologia e pluralidade. Essas dimensões são muito amplas e, em certo sentido, abstratas. De maneira que no decorrer das vinhetas elas foram se revelando.

Assumidas narrativa e discursivamente pelo sujeito da enunciação, foram ganhando concretude e, consequentemente, um caráter mais específico em cada manifestação conforme desenvolvi no segundo capítulo. Reunindo as análises, é possível perceber algumas áreas em que a atuação da emissora - com base nos cinco eixos mencionados - se dá com bastante ênfase, e outras que nem chegam a ser citadas como áreas de interesse.

Para colocar melhor esse ponto, retomarei algumas peças exibidas ao longo da história da emissora. A primeira delas é uma vinheta veiculada entre os anos de 1969 e 1975. O vídeo traz o desenho de uma "boca" que diz: "notícia, amor, emoção e alegria": 
Fig. 19: Vinheta - o que é bom está na Globo II

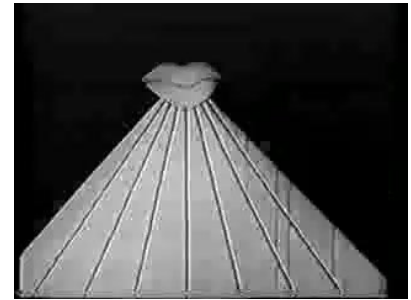

Fig. 19/1

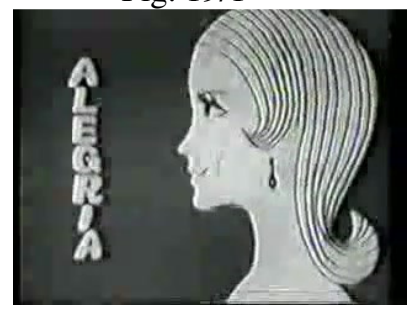

Fig. 19/4

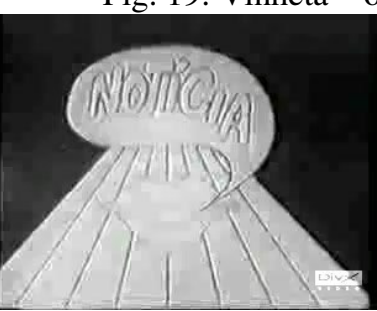

Fig. 19/2

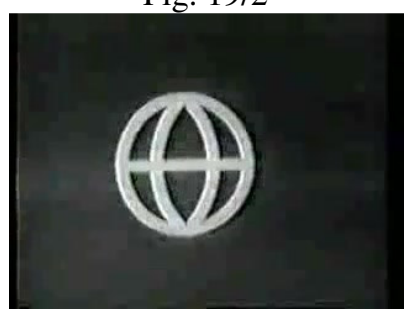

Fig. 19/5

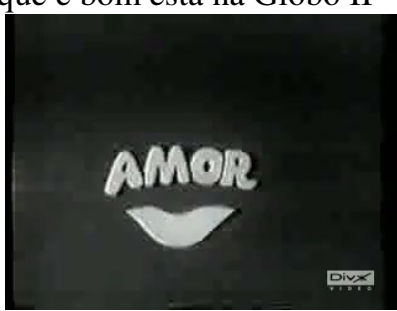

Fig. 19/3

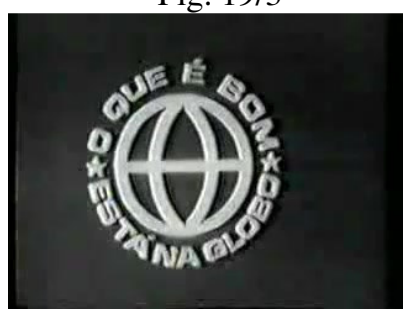

Fig. 19/6

Tal boca figurativiza a emissora como sujeito narrador e destinador da mensagem. Essa interpretação pode ser obtida pelo modo como os traços ou linhas se desenvolvem na vinheta, partindo, com certa profundidade de campo, do centro para as margens da tela (fig.19/1), criando um efeito de "emissão", "difusão" ou "propagação" que é próprio de um meio massivo como a televisão (sistema "um-todos"); além disso, constitui-se visualmente uma "boca sem corpo" (fig. 19/1 a fig. 19/3), tal como a "voz sem corpo" que sonoramente estamos acostumados a ouvir narrar os slogans nos dias de hoje; e, por fim, não há no vídeo qualquer trabalho de transição associando metonimicamente tal boca à figura humana que aparece posteriormente nas imagens (fig. 19/4).

Antes, existe uma construção visual em que tal "boca", depois de "falar sobre notícias" (fig. 19/2) e dar origem à palavra "amor" (fig. 19/3) - sendo que neste caso a palavra chega a ter o contorno ondulado da boca e ocupar não menos que a posição do lábio superior, fundamental, portanto, para sua articulação - se transforma na palavra "emoção" e, na sequência, como um flash de luz, na palavra "alegria". Estas últimas, dispondo-se significativamente de maneira vertical, conformam uma linha divisória entre os espaços que estão atrás delas e à sua frente (fig. 19/4). Apenas depois surge da lateral do quadro a figura feminina. Esta se aproxima em direção a tal linha divisória e a certa distância - não muito longe - a contempla, mirando-a diretamente, da mesma forma que fazemos ao assistir televisão (fig. 19/4). 
Desse modo, a figura feminina representa o público que acompanha a programação da TV. As palavras "emoção" e "alegria", por sua vez, não apenas constituem alguns de seus conteúdos, vindo a figurativizar a própria televisão ou o ecrã televisivo - note-se, nesse sentido, o caráter crescente em termos de importância que o discurso dá a ver no que diz respeito à "informação", "amor", "emoção" e "alegria" - mas, sobretudo, define uma ideia de contentamento para os traços ascendentes que caracterizam a fisionomia da mulher diante de tais conteúdos (fig. 19/4), como se também o público achasse "bom" o que está na Globo. De modo que a narrativa pode ser organizada da seguinte maneira:

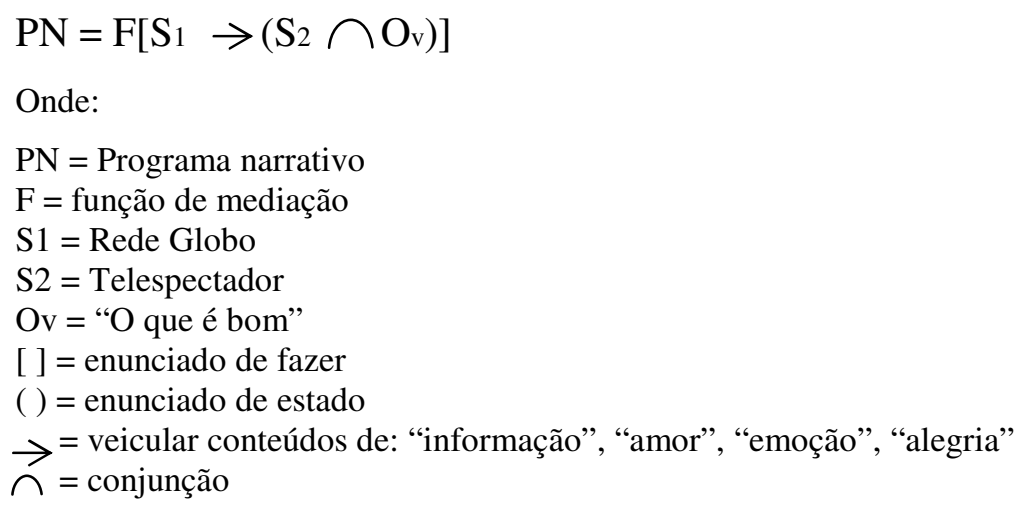

Desde então, surgiram outras peças focadas nessas mesmas áreas. Na era Hans Donner, quer dizer, já sob o atual projeto identitário da marca, posso citar alguns exemplos. Um deles é o jingle “A Globo 90 é nota 100”, que analisei no segundo capítulo. Uma peça realizada numa época em que a emissora constituía-se líder absoluta de audiência. Nela, a Rede Globo, como um enunciador coletivo, diz "levar à casa" do telespectador tudo o que "o povo gosta" e precisa para "ser feliz": "emoção", "esperança", "alegria", "juventude" e "amor" (veja análise, pág. 47-53).

Outra campanha, já em tempos em que a emissora enfrenta uma concorrência mais acirrada, é "A gente se liga em você", que foi ar no decorrer de 2011 e 2012. Nas peças que a compõe, a emissora constrói seu discurso afirmando proporcionar ao telespectador o que ele quer em termos de conteúdo. Algumas delas também foram analisadas no segundo capítulo. Basta lembrar o conjunto de vinhetas que apresentei ao abordar o anagrama como efeito expressivo. Em tais peças, o público é retratado assistindo aos seguintes conteúdos: "telejornal", "matéria de esporte", "telenovela" e "programa de humor". De idosos a crianças, todos parecem estar satisfeitos, pois veem na tela exatamente o que queriam ou esperavam ver (veja análise, pág. 67-75). 
Em 2014, com a mudança na logomarca - de cinza para branco - a emissora dá início às comemorações de seus 50 anos. O vídeo institucional destaca os conteúdos voltados para a "informação" (fig. 20/3) e a "emoção" (fig. 20/5), já que, como justifica o novo slogan, "a Globo está em movimento para acompanhar a vida, o mundo e você". Portanto, é como se essas áreas, apesar de todas as mudanças contextuais sofridas ao longo do tempo, fossem ou continuassem sendo os conteúdos de verdadeiro interesse do público - razão pela qual também são as áreas de interesse que a emissora privilegia com seu caráter "dinâmico" (fig. 20/2) e "inovador" (fig. 20/4).

Fig. 20: Vinheta - A Globo está em movimento

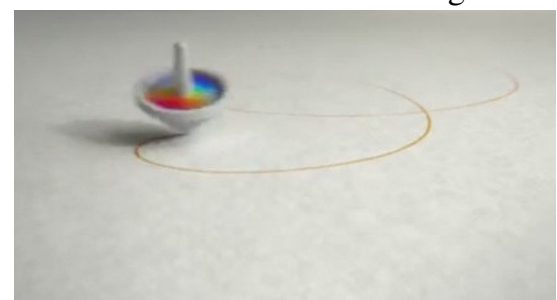

Fig. 20/1

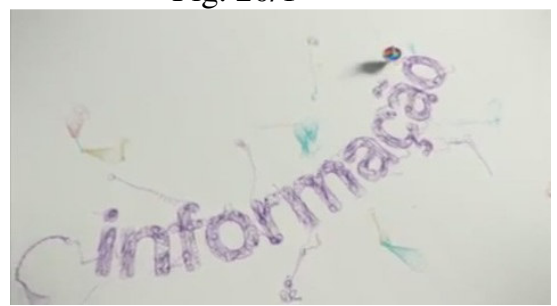

Fig. 20/3

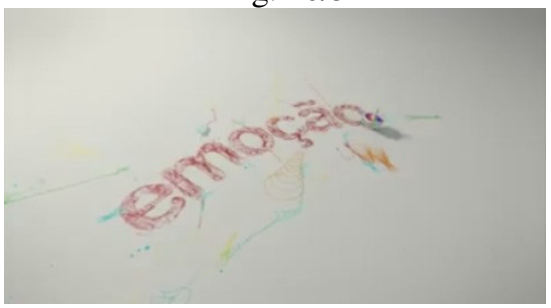

Fig. 20/5

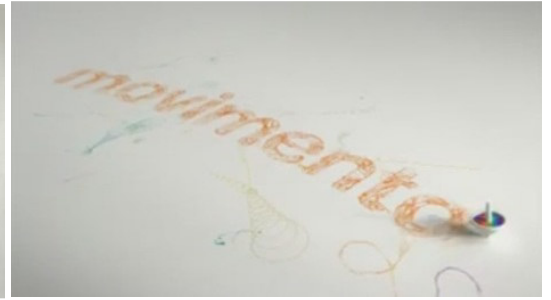

Fig. 20/2

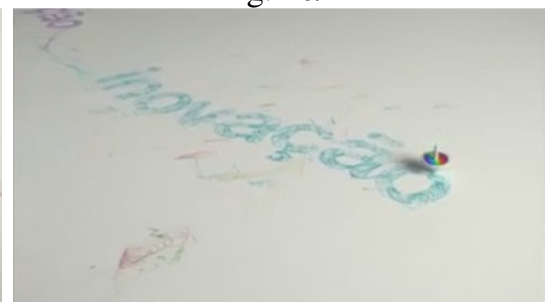

Fig. 20/4

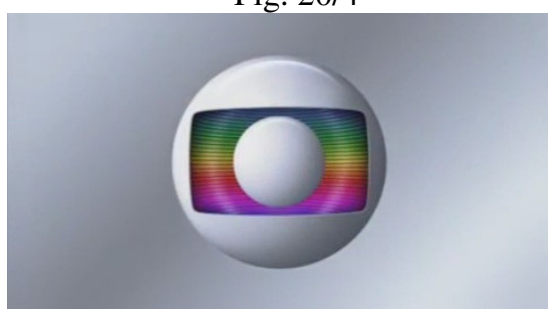

Fig. 20/6

A vida está em movimento O mundo está em movimento Você está em movimento A Globo está em movimento Para acompanhar a vida, o mundo e você Divertindo, informando, inovando, emocionando Se movimentando com você. Ploom-ploom (Vinheta - A Globo está em movimento) 
É possível observar no texto (verbal-oral, narração em off) a repetição da palavra "movimento" - que é também a primeira palavra que aparece nas imagens (fig. 20/2 verbal-visual). Em termos expressivos, tal ideia é reiterada pelos movimentos circulares de um pião que não gira sobre o chão, mas sobre uma superfície de papel, e cuja ponta não é de ferro, mas de caneta hidrográfica (fig. 20/1). Esses elementos figurativos são notadamente objetos lúdicos, utilizados por crianças, nos conduzindo, assim, à temática da infância. Visto que se trata de um anúncio institucional, tal "infância" transmite a ideia de um "novo ciclo" para a Globo - o que, em parte, é assinalado narrativamente pela ação reflexiva da emissora $\left(\mathrm{S}_{1}=\mathrm{S} 2\right)$, que se volta na vinheta para seu próprio fazer-televisivo:

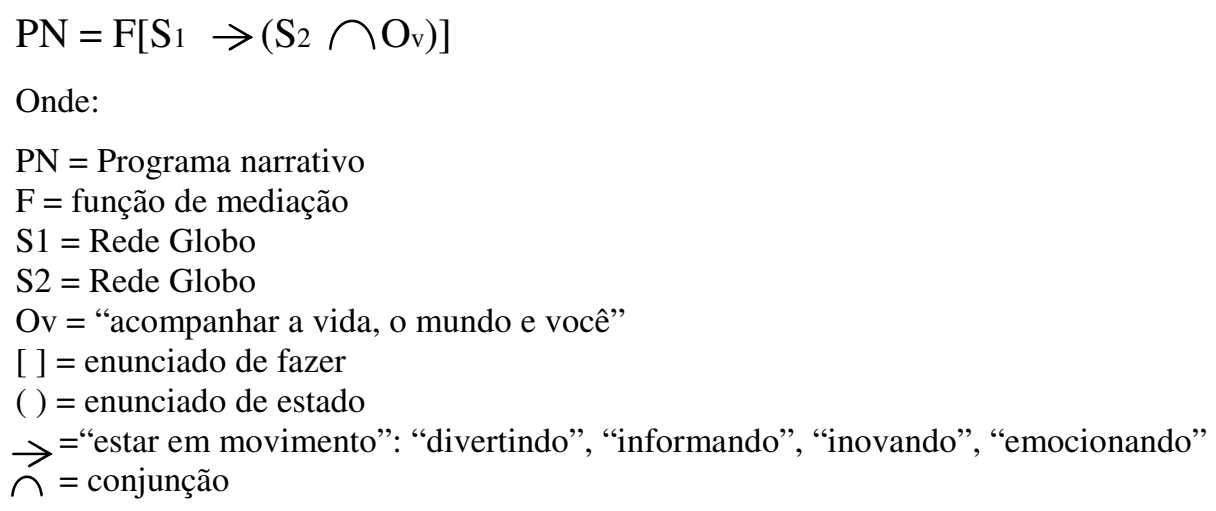

Tal reflexividade já havia despontado em programas narrativos de outras vinhetas mais precisamente na campanha "A gente se liga em você", conforme apontei no segundo capítulo. E reaparece com mais ênfase neste vídeo comemorativo, em que a emissora olha para seu passado, sua história de vida e, sobretudo, para este seu atual momento, projetando, de certa forma, também o futuro - os próximos cinquenta anos, por assim dizer; um novo ciclo. Afinal, para perceber e acompanhar as mudanças no âmbito da vida, do mundo e do público, como a emissora afirma fazer, é necessário ter uma visão sobre o todo: o que era, o que é, e o quem vem pela frente. Todavia, como os elementos de base da logomarca - "esfera", "retângulo", "esfera" - não são alterados no novo visual, também não há, consequentemente, mudanças substanciais em relação ao projeto identitário que ela propõe.

Nesse sentido, o paralelismo que o discurso cria entre as mudanças da vida, do mundo e do telespectador e as mudanças da própria televisão, quer dizer, entre os objetos do mundo natural e os objetos do mundo representado, torna evidente que a função de mediação permanece como a enunciação fundamental da marca. A mesma coisa se dá com 
a promessa de interação entre o enunciador e o enunciatário, projetados, inclusive, como sempre foram $($ Globo $=$ enunciador coletivo; você $=$ enunciatário individual $)$, conforme o texto: "a Globo está em movimento (...) se movimentando com você”; e o caráter global que a especifica, pois a emissora segue "acompanhando o mundo". O território também continua sendo o da televisão e isso não apenas pela referência do nome da emissora (verbal-oral) ou sua logo ao final do vídeo (visual), mas também pela sonoridade autorreferencial do plim-plim, que com a nova logo ganha na vinheta um caráter mais extenso e oblíquo, assemelhando-se a um "ploom-ploom"; e pelos tons de vermelho, verde e azul que fazem referência às cores-luz da própria televisão. Os valores, por sua vez, também são os mesmos: tecnologia por meio da palavra "inovação" (verbal-oral; verbalvisual), e pluralidade pela abrangência da proposta de "acompanhar a vida" (verbal-oral), o que implica todas as "formas de vida".

Não somente o projeto de identidade proposto para o futuro é o mesmo como ele também continua direcionado para as mesmas áreas de conteúdo de quando a emissora surgiu - conforme retomei a partir das quatro vinhetas citadas, pertencentes às quatro principais fases da emissora: os anos iniciais, a época de auge, o tempo de quebra da hegemonia e o emblemático momento da virada dos cinquenta anos. Em textos como esses, a televisão se autodescreve e justifica como meio de entretenimento e até de informação, mas nem sequer cita seu papel em promover a educação - o que na Constituição Federal aparece como dever primário:

\begin{abstract}
Art. 221. A produção e a programação das emissoras de rádio e televisão atenderão aos seguintes princípios: I - preferência a finalidades educativas, artísticas, culturais e informativas; II - promoção da cultura nacional e regional e estímulo à produção independente que objetive sua divulgação; III regionalização da produção cultural, artística e jornalística, conforme percentuais estabelecidos em lei; IV - respeito aos valores éticos e sociais da pessoa e da família.
\end{abstract}

Desse modo, a mensagem que dá início às comemorações dos cinquenta anos da emissora não poderia ser mais explícita ao utilizar a figura do "pião", tal como ele está desenhado e pela maneira que se desenvolve na tela, como elemento de metáfora. Explorando relações como /passado/ vs. /futuro/ ou /tradição/ vs. /inovação/ e /estática/ vs. 
/movimento/, presentes no discurso como um todo, esse antigo brinquedo de criança apenas ganha na vinheta uma roupagem moderna e, girando em torno de seu próprio eixo, movimenta-se sem praticamente sair do lugar. Elementos cromáticos (branco por fora, colorido por dentro), eidéticos (esfericidade) e cinéticos (giratório) se firmam como aspectos comuns aos objetos comparados, permitindo o estabelecimento da metáfora: esse pião é a Globo.

\subsection{A competência}

É interessante notar como o contrato proposto e, consequentemente, os conteúdos com os quais a emissora se compromete - ou promete ao telespectador - mantêm estreita relação com os valores modais que organizam os discursos institucionais da Globo.

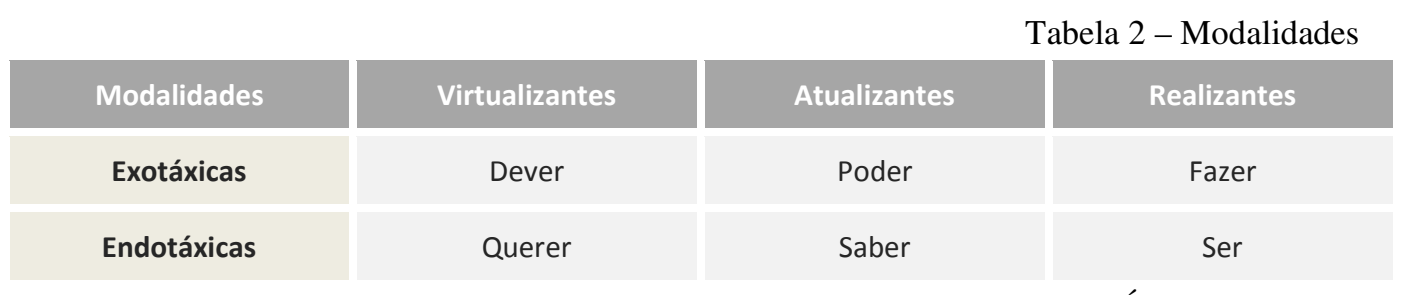

(GREIMAS; COURTÉS, 1983, p. 283)

Para compreender o que acontece, vale lembrar que: 1) a competência modal compreende uma organização hierárquica, um percurso tensivo que leva à realização - o "ser" e o "fazer"; 2) designam-se "exotáxicas as modalidades capazes de entrar em relações translativas (de ligar enunciados que têm sujeitos distintos), e como endotáxicas as modalidades simples (que ligam sujeitos idênticos ou em sincretismo" (GREIMAS; COURTÉS, 1983, p. 283).

Com isso em mente, em relação ao enunciador, tem-se nos discursos institucionais da Rede Globo a projeção de um saber e poder-fazer (modalidades atualizantes que envolvem, neste caso, a compreensão do caráter plural e tecnológico do meio, quer dizer, os valores destacados no projeto da marca) sempre regidos por um querer e dever-fazer (modalidades virtualizantes que expressam, respectivamente, "vontade própria" e "sistema de coerções") endotáxicos e nunca exotáxicos. De maneira mais precisa, os discursos costumam se desenvolver em torno de um "querer-ser" e um "querer-fazer". Algumas mensagens chegam até a projetar um "dever-ser", mas em momento algum se observa nas vinhetas um “dever-fazer". 
Se nos dois primeiros casos o caráter endotáxico se mostra evidente, visto que é a modalidade do "querer" que rege o "ser" e o "fazer", nos dois últimos pode-se considerar o "dever-ser" e "dever fazer" como duas estruturas modais idênticas quanto ao enunciado modalizante que comportam, mas distintas quanto aos enunciados que são modalizados. De modo que a estrutura modal do "dever-ser" se opõe a do "dever-fazer", já que na primeira a relação predicativa incide sobre o objeto modalizado, exprimindo "necessidade" e, portanto, um caráter endotáxico; e, na segunda, a relação predicativa incide sobre o sujeito que modaliza, exprimindo "prescrição" e, portanto, um caráter exotáxico (GREIMAS; COURTÉS,1983, p. 117-118).

Assim, a Globo é sempre projetada nas vinhetas institucionais como o sujeito que modaliza $\left(\mathrm{S}_{1}\right)$ e nunca como o sujeito que é modalizado $\left(\mathrm{S}_{2}\right)$ - a não ser por ela própria $\left(\mathrm{S}_{1}\right.$ $=\mathrm{S}_{2}$ ) - como demonstrei na primeira parte do segundo capítulo. De modo que não transparece nas mensagens qualquer tipo de influência ou sistema de coerções externo. Livre, a Rede Globo se autodeclara como meio de entretenimento e informação, passando por alto a educação - sem nem mesmo explorar as ações pontuais que, de fato, desenvolve nessa área. A pergunta é: por quê?

\subsection{A performance}

A resposta, que define um perfil identitário à televisão, parece estar realmente ligada ao modo de pensar de Walter Clark que, ao desenvolver estratégias para consolidar e projetar a Rede Globo como líder de audiência na década de 70, dizia: "televisão não é programa, é programação" (apud SOUZA, 2004, p. 53).

Isso porque de nada vale ter bons programas se eles estiverem mal alocados na grade televisiva e, em consequência disso, não atingirem seu público ideal. Em outras palavras, se desenhos infantis são feitos para crianças e programas culinários são para donas de casa é necessário que eles sejam exibidos em horários adequados a cada um desses públicos. Essa é a ideia por trás de um conceito operacional chamado verticalidade da programação. Com base nele, se definem os horários de inserção e a sequencialidade de programas ao longo do dia (BORELLI; PRIOLLI, 2000, p. 81).

Se determinada proposta vertical for bem sucedida, ela provavelmente será repetida ao longo da semana e até do mês, de modo que o público volte todos os dias - ou, se for o caso, em um dia específico da semana - no mesmo horário, para ver certo programa. As estratégias nesse sentido tendem a condicionar o público, fidelizando a audiência, e fazem 
parte do que se tem chamado de horizontalidade da programação. Para isso, no entanto, é necessário que os programas preservem dia a dia as características do gênero em que estão inseridos, respeitando a expectativa do telespectador. Assim, um programa de entretenimento deverá seguir sob esse enfoque; e a mesma coisa se passa com as atrações de cunho informativo e educativo. O que significa dizer, em última instância, que a horizontalidade é na verdade a estipulação de horários fixos para certos gêneros.

Assim, interessa-nos saber: como se distribuem tais gêneros na programação da Rede Globo? As tabelas que seguem nos ajudarão a visualizar como costuma se comportar a grade da emissora ${ }^{40}$.

Tabela 3 - Grade televisiva (Manhã)

\begin{tabular}{|c|c|c|}
\hline \multicolumn{3}{|r|}{ Manhã } \\
\hline Horário & Programa & Descrição \\
\hline $4 h 58$ & Sagrado & $\begin{array}{l}\text { O Sagrado faz uma releitura do mundo atual sob a ótica da diversidade } \\
\text { religiosa. Semanalmente, são exibidas discussões sobre assuntos variados, } \\
\text { com representantes de diversas religiões. }\end{array}$ \\
\hline $5 h 01$ & $\begin{array}{l}\text { Telecurso } \\
\text { Profissionalizante }\end{array}$ & Teleaulas voltadas para o Ensino Profissionalizante. \\
\hline $5 \mathrm{~h} 17$ & Telecurso TEC & $\begin{array}{l}\text { Voltado para a formação técnica de nível médio, de qualificação e } \\
\text { habilitação profissional, o Telecurso TEC apresenta teleaulas para três cursos } \\
\text { técnicos: Administração, Comércio e Secretariado. }\end{array}$ \\
\hline 5 h33 & $\begin{array}{l}\text { Telecurso Ensino } \\
\text { Médio }\end{array}$ & Teleaulas voltadas para o Ensino Médio. \\
\hline $5 h 45$ & $\begin{array}{l}\text { Telecurso Ensino } \\
\text { Fundamental }\end{array}$ & Teleaulas voltadas para o Ensino Fundamental. \\
\hline 6h01 & Globo Rural & $\begin{array}{l}\text { Programa que traz notícias sobre agronegócios, empreendimentos rurais e } \\
\text { os principais índices do setor agrícola. }\end{array}$ \\
\hline $6 h 32$ & Bom Dia local & Telejornal que traz as notícias locais. \\
\hline 7h30 & Bom Dia Brasil & $\begin{array}{l}\text { Telejornal com as primeiras notícias do dia com comentários e análise crítica } \\
\text { dos fatos. }\end{array}$ \\
\hline $8 h 28$ & Mais Você & $\begin{array}{l}\text { O programa investe em matérias mais informativas e na prestação de } \\
\text { serviços de olho nas atualidades e assuntos que interessam à família como } \\
\text { economia popular, saúde e comportamento. }\end{array}$ \\
\hline
\end{tabular}

\footnotetext{
${ }^{40}$ Os horários, programas e descrições foram retiradas do site da Globo, baseados na data de 21/06/2013. Disponível em: http://redeglobo.globo.com/programacao.html. Acesso em 20 de junho de 2013. Os cálculos apresentados adiante no texto levam em conta a exibição de comerciais e excluem o programa político apartidário.
} 


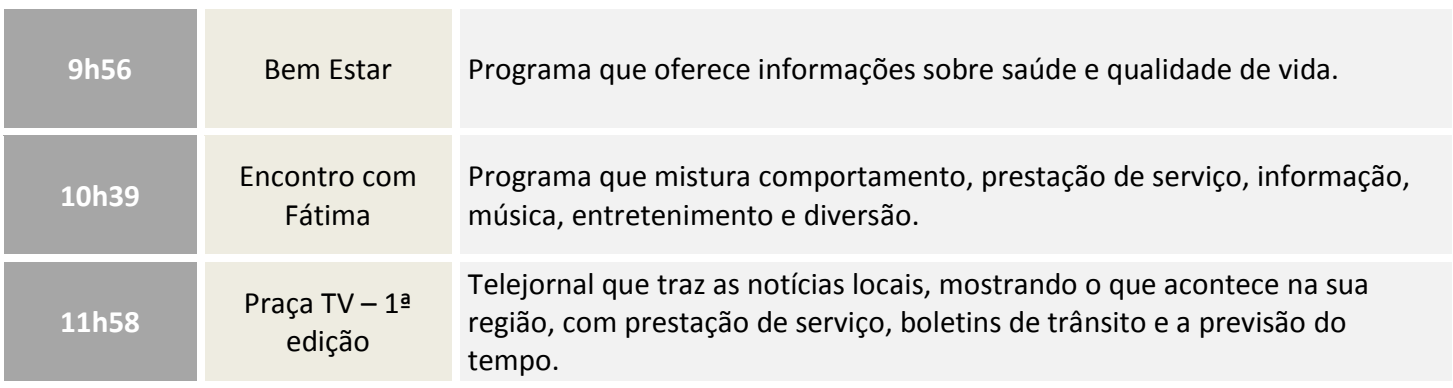

Como se vê, na parte da manhã são exibidos 12 programas. Tomando em consideração a descrição que a Rede Globo disponibiliza em seu site, 6 possuem fins educativos (Sagrado, Telecurso Profissionalizante, Telecurso TEC, Telecurso Ensino Médio, Telecurso Ensino Fundamental, Bem Estar); 4 são informativos (Globo Rural, Bom Dia Local, Bom Dia Brasil, Praça TV - $1^{\text {a }}$ edição); e 2 se voltam para o entretenimento (Mais Você e Encontro com Fátima). No entanto, dos 429 minutos totais de programação no período, 106 são destinados à educação; 154 à informação e 169 ao entretenimento.Visualizando de outro modo, a Globo destina, aproximadamente, $24,70 \%$ do período da manhã para a Educação; 35,89\% para o segmento informativo; e 39,39\% para o entretenimento.

Tabela 4 - Grade televisiva (Tarde)

\begin{tabular}{|c|c|c|}
\hline \multicolumn{3}{|r|}{ Tarde } \\
\hline Horário & Programa & Descrição \\
\hline $12 \mathrm{~h} 45$ & Globo Esporte & $\begin{array}{l}\text { Programa que atualiza o noticiário esportivo do dia com os destaques do } \\
\text { Brasil e do mundo e ainda com versões regionais. }\end{array}$ \\
\hline $13 \mathrm{~h} 20$ & Jornal Hoje & $\begin{array}{l}\text { Atualiza o telespectador quanto às principais notícias e traz reportagens } \\
\text { sobre moda, comportamento, arte, cultura e culinária. }\end{array}$ \\
\hline $13 \mathrm{~h} 49$ & Vídeo Show & $\begin{array}{l}\text { A atração mostra, de forma bem-humorada, os bastidores da TV Globo } \\
\text { e as principais notícias sobre o mundo dos astros e das estrelas. }\end{array}$ \\
\hline $14 h 41$ & O profeta & $\begin{array}{l}\text { Novela. A trama conta a história de Marcos, jovem que nasceu com o dom } \\
\text { de prever o futuro. }\end{array}$ \\
\hline $15 \mathrm{~h} 57$ & Sessão da Tarde & Variável \\
\hline $17 \mathrm{~h} 28$ & Globo Notícia & Boletim com as principais informações do Brasil e do mundo. \\
\hline $17 \mathrm{~h} 32$ & Malhação & Novela. A trama conta sobre as aventuras da galera do Colégio Quadrante. \\
\hline
\end{tabular}

$\mathrm{Na}$ parte da tarde são exibidos 7 programas, totalizando 313 minutos de programação. Desses, nenhum é dedicado à educação; há 3 programas de cunho informativo que somam 73 minutos (Globo Esporte, Jornal Hoje, Globo Notícia); e 4 de entretenimento que juntam 240 minutos (Vídeo Show, O profeta, Sessão da Tarde, 
Malhação). Assim, 23,33\% do período vespertino da Globo está dedicado à informação e $76,67 \%$ ao entretenimento.

Tabela 5 - Grade televisiva (Noite)

\begin{tabular}{|c|c|c|}
\hline \multicolumn{3}{|r|}{ Noite } \\
\hline Horário & Programa & Descrição \\
\hline $18 \mathrm{~h} 03$ & Flor do Caribe & $\begin{array}{l}\text { Novela. Na trama, a vida do casal Cassiano e Ester sofre um revés com a } \\
\text { volta de Alberto, amigo de infância da dupla, à Vila dos Ventos. }\end{array}$ \\
\hline $18 h 57$ & $\begin{array}{l}\text { Praça TV - } \\
2 \text { a edição }\end{array}$ & $\begin{array}{l}\text { Telejornal que traz as notíciais locais, com prestação de serviço, boletins de } \\
\text { trânsito e a previsão do tempo. }\end{array}$ \\
\hline $19 h 16$ & Sangue bom & Novela. \\
\hline $20 h 30$ & $\begin{array}{c}\text { Programa Político } \\
\text { Apartidário }\end{array}$ & Horário dedicado à propaganda política obrigatória \\
\hline $20 h 40$ & Jornal Nacional & $\begin{array}{l}\text { Telejornal que mostra o que acontece de mais importante no Brasil e no } \\
\text { mundo. }\end{array}$ \\
\hline $21 \mathrm{~h} 20$ & Amor à Vida & $\begin{array}{l}\text { Novela. Conta a história de uma família que vive em São Paulo e a disputa } \\
\text { de poder entre seus membros. }\end{array}$ \\
\hline $22 \mathrm{~h} 36$ & Globo Repórter & $\begin{array}{l}\text { Programa que apresenta reportagens sobre assuntos variados e } \\
\text { curiosidades do Brasil e do mundo. }\end{array}$ \\
\hline $23 h 36$ & $\begin{array}{l}\text { O dentista } \\
\text { mascarado }\end{array}$ & Série cômica. \\
\hline 00h20 & Jornal da Globo & $\begin{array}{l}\text { Telejornal que mostra o que aconteceu no dia. Abre espaço para a crônica e } \\
\text { a opinião. }\end{array}$ \\
\hline $00 h 56$ & Programa do Jô & Programa de entrevistas. \\
\hline $02 \mathrm{~h} 12$ & $\begin{array}{l}\text { Corujão do } \\
\text { Esporte }\end{array}$ & Programa sobre notícias do mundo esportivo. \\
\hline $02 \mathrm{~h} 55$ & Corujão & Sessão de filmes, séries e desenhos. \\
\hline
\end{tabular}

A noite da Globo conta com 11 programas, num total de 479 minutos. Desses, nenhum se encaixa no gênero educativo; 4 se voltam para a informação, totalizando 155 minutos (Praça TV - 2a edição, Jornal Nacional, Globo Repórter, Corujão do Esporte) e 6 para o entretenimento, numa soma de 324 minutos (Flor do Caribe, Sangue bom, Amor à Vida, O Dentista Mascarado, Programa do Jô, Corujão). Assim, 32,36\% da programação noturna está voltada para o gênero informativo e $67,64 \%$ para o entretenimento.

Tabela 6 - Distribuição dos gêneros na programação diária da Rede Globo

\begin{tabular}{|c|c|c|c|c|}
\hline & \multicolumn{3}{|c|}{ Distribuição dos gêneros na programação diária da Rede Globo } \\
\hline & Minutos & Educação & Informação & Entretenimento \\
\hline Manhã & 429 & 106 & 154 & 169 \\
\hline Tarde & 313 & 0 & 73 & 240 \\
\hline Noite & 479 & 0 & 155 & 324 \\
\hline Total & 1221 & 106 & $\mathbf{3 8 2}$ & $\mathbf{7 3 3}$ \\
\hline Percentual & $\mathbf{1 0 0 \%}$ & $\mathbf{8 , 6 8 \%}$ & $\mathbf{3 1 , 2 8 \%}$ & $\mathbf{6 0 , 0 3 \%}$ \\
\hline
\end{tabular}


Como se vê, no final de um dia de programação a diferença de espaço destinado a cada um dos gêneros é brutal. Dos 1.221 minutos totais, a educação fica com 106, aproximadamente 8,68\% do espaço diário; à informação se destinam 382 minutos, somando $31,28 \%$; e o entretenimento tem 733 minutos, ocupando $60,03 \%$ da grade.

Outra análise pertinente é saber que gênero predomina no prime-time da televisão. Esse rótulo - horário nobre - evidentemente não é casual. Ele aponta para a faixa horária (entre $19 \mathrm{~h}$ e $22 \mathrm{~h}$ ) comercialmente mais valorizada da televisão em vista do maior número de aparelhos ligados e também da abrangência ou diversidade do público telespectador nesse período, diferentemente do que acontece em certos horários da manhã ou da madrugada, por exemplo, cuja audiência tende a ser mais restrita e segmentada. O horário nobre é, certamente, o mais geralista da televisão aberta. Nele se ligam extremos cronológicos, sociais e culturais. Desse modo, quando a televisão fala para essa audiência tão vasta e diversificada, o que ela diz? A tabela desenhada nos leva aos números da programação vertical que a sociedade já conhece: são 76 minutos de informação em forma de telejornal intercalando 150 de entretenimento em forma de novela.

Esse conjunto de escolhas que a emissora faz em relação à distribuição dos gêneros na programação como um todo, e no horário nobre em especial, diz muito sobre ela mesma. De acordo com Petraglia, a programação de uma emissora não resulta apenas de fatores ligados à audiência e ao público-alvo, mas, - e, eu me atrevo a dizer, sobretudo também da projeção de uma imagem institucional. Nas palavras do autor, "o aumento do número de programas de determinado gênero na mesma emissora promove uma imagem que torna a rede conhecida pelo público" (PETRAGLIA apud SOUZA, 2004, p.56). Assim, qual é o perfil identitário que a Rede Globo constrói para si própria por meio de sua programação? Quando as pessoas pensam em Rede Globo em que tipo de produto audiovisual elas pensam? Novela? Telejornal? Sim - novela e telejornal - e, muitas vezes, exatamente nessa ordem ${ }^{41}$.

\subsection{A sanção}

Com base na performance do enunciador, o enunciatário finaliza seu fazerinterpretativo com um juízo epistêmico, um crer que ele emite sobre os enunciados de estado que lhe foram submetidos. No caso da Globo, tais enunciados explicitavam ao mesmo tempo um contrato e um perfil identitário. O contrato, como vimos, se articula em

\footnotetext{
${ }^{41}$ LUCA, 2013, p. 230-234.
} 
torno dos cinco eixos mencionados no início deste capítulo. E o perfil identitário pelo direcionamento da mediação proposta a conteúdos de entretenimento e informação.

Ter a emissora se tornado a mais influente rede de televisão do país, ocupando até hoje um lugar de referência no imaginário coletivo, evidencia uma sanção positiva em base cognitiva, quer dizer, um reconhecimento por parte do enunciatário. E, em termos pragmáticos, pode-se dizer que tal juízo epistêmico tem resultado em recompensadores índices de audiência. Apenas como exemplo, segundo dados divulgados em reportagem do site $\mathrm{Uol}^{42}$, foram da Globo os 47 programas mais visto na televisão brasileira em 2012:

Tabela 7 - Os programas mais vistos da TV brasileira

\section{Os programas mais vistos da TV brasileira}

\begin{tabular}{|c|c|c|}
\hline 19 Novela das $21 \mathrm{~h}$ & 17을special Chico e Amigos & 33 Caldeirão do Huck \\
\hline 2o Jornal Nacional & 18ㅇ Vale a Pena Ver de Novo & 34 Supercine \\
\hline 3ㅇ Novela das $19 \mathrm{~h}$ & 19o Domingão do Faustão & 35음ídeo Show \\
\hline 4오 Show de terça-feira I & 200 Série brasileira & 36 Na Moral \\
\hline 5 Big Brother Brasil & 210 Malhação & 37으 Esquenta \\
\hline 60 Praça TV 2a edição & 22으 Cinema Especial Noite & 38ㅇ Sessão da Tarde \\
\hline 70 A Grande Família & 23으 Show de Quinta-feira & 39ㅇ Os Caras de Pau \\
\hline 8ㅇ Festival Nacional & 240 The Voice Brasil & 40ㅇ Show de Quinta-feira \\
\hline 9ㅇ Futebol (meio de semana) & 25o Carnaval & 410 Globo Esporte \\
\hline 10 Novela das $18 \mathrm{~h}$ & 26ㅇ Show de Terça-feira & 42 Jornal Hoje \\
\hline 110 Globo Repórter & 270 Acampamento de férias & 43ㅇ TUF- Em Busca de Campeões \\
\hline 12ㅇ Zorra Total & 28o Temperatura Máxima & 44으 Criança Esperança Vesp. \\
\hline 13ㅇT Tela Quente & 290 UFC Combate & 45ㅇ Praça TV 1ạ edição \\
\hline 140 Fantástico & 30 Vídeo Game Verão & 46 TV Xuxa Vesp. \\
\hline 150 Criança Esperança Not. & 31으 Show de Sexta-feira & 47을 Aventuras do Didi \\
\hline 160 Novela das $23 \mathrm{~h}$ & 32ㅇ Profissão Repórter Not. & 48을 Rei Davi (Record) \\
\hline
\end{tabular}

Seguindo uma longa tradição, as primeiras posições são compostas esmagadoramente por conteúdos de entretenimento e alguns de informação. Estes são exatamente os conteúdos valorizados pela emissora em suas vinhetas institucionais, o que nos leva a concluir que as estratégias manipulatórias utilizadas na conformação das

\footnotetext{
${ }^{42}$ Disponível em: http://noticias.uol.com.br/ooops/ultimas-noticias/2012/11/06/com-muita-folga-globo-tem-os-47-programasmais-vistos-de-2012.htm. Acessado em: 20 de junho de 2013.
} 
manifestações da marca no âmbito da comunicação estão sendo bem-sucedidas moldando não apenas o fazer-televisivo da Rede Globo, mas, até certo ponto, por conta da modalização que efetuam sobre o público, os horizontes da televisão como um todo.

Tal afirmação se ampara no fato de que existem outros tipos de programas - de caráter mais construtivo e emancipador - sendo oferecidos por emissoras concorrentes em faixas horárias correspondentes às da Globo. Todavia, o público não muda de canal e quando o faz continua em busca dos mesmos conteúdos (note o $48^{\circ}$ programa mais assistido). Comportamentos assim, evidentemente, envolvem diversos fatores externos ao telespectador, como a disponibilidade de sinal de algumas redes e a qualidade técnica e de linguagem de certas produções. No entanto, não se pode dizer que ela não recaia também sobre o "gosto da audiência". Neste caso, os conteúdos que o público valoriza ou foi modalizado a valorizar - entretenimento e informação. 


\section{Considerações finais}

Todo o desenvolvimento deste trabalho esteve alicerçado na tese de que o sucesso da Rede Globo como empresa televisiva mantinha estreita relação com a criação e exploração de uma identidade audiovisual. De modo que a investigação avançou no sentido de expor que identidade era essa e como ela se projetava para o público.

No primeiro capítulo, a partir do estudo do símbolo que representa atualmente a emissora, foi possível chegar aos cinco eixos que estruturam o projeto identitário da marca: 1) mediação como enunciação fundamental; 2) interação enunciador-enunciatário como promessa; 3) abrangência global como especificação da promessa; 4) televisão como território de atuação; e 5) tecnologia e pluralidade como valores. Com isso, revelou-se haver realmente uma diretriz quanto ao fazer televisivo da emissora e, consequentemente, a proposição de um contrato para o telespectador.

No segundo capítulo, observamos que tais eixos norteadores se mantinham nas manifestações da marca no âmbito da comunicação. As análises buscaram demonstrar como esses elementos tão abstratos do projeto eram dados a conhecer ao público e que estratégias a rede de televisão utilizava para modalizar o telespectador a aceitar o contrato proposto. Tendo em vista que os discursos oscilavam conforme as necessidades contextuais, privilegiando ora um ora outro eixo, o principal a destacar é a coerência existente entre tais manifestações e o projeto da marca ao longo dos anos, pois nessa coerência e persistência é que se encontra o caráter identitário que afirmei haver. $\mathrm{O}$ segundo ponto alto revelado pelas análises foi o fato de que a atuação da emissora, com base nos cinco eixos mencionados, sempre esteve dirigida a áreas específicas, a saber, o entretenimento e a informação.

Esse perfil televisivo foi exposto com maior ênfase no terceiro capítulo - com a retomada de peças institucionais pertencentes às diferentes fases da emissora ao longo de toda a sua trajetória. A partir disso, busquei avaliar a relação que os conteúdos da grade mantinham com as comunicações da marca e, por extensão, com o projeto identitário. Em resultado, encontramos absoluta coerência entre o contrato proposto e a performance do enunciador, ou seja, entre o projeto identitário, as manifestações da marca no âmbito da comunicação e as manifestações no âmbito do produto - o que justifica a aderência do enunciatário, sua sanção positiva em base cognitiva e pragmática. 
No entanto, como bem colocam Greimas e Courtés, "o juízo epistêmico não depende somente do valor do fazer interpretativo que se supõe o preceda (isto é, do saber que incide sobre as modalizações veridictórias do enunciado), mas também - numa medida a ser ainda determinada - do querer-crer e do poder-crer" (1983, p. 152). Isso indica que, embora o fazer persuasivo do enunciador deva ser levado em conta - e esse foi o objetivo realizado neste trabalho - existem muitos outros fatores envolvidos na conformação da trajetória de sucesso da Rede Globo.

Assim, o que se pode afirmar é que, dada a coerência entre o projeto e as manifestações da marca, a parcela de responsabilidade que cabia nesse quadro à criação e exploração de uma identidade audiovisual foi cumprida com sucesso, comprovando a tese inicial. 


\section{Referências bibliográficas}

ALVES, V. Tupi: uma linda história de amor. São Paulo: Imprensa oficial, 2008.

AMORIN, E. R. do. História da TV brasileira. Coleção Cadernos de Pesquisa. São Paulo: Centro Cultural São Paulo, 2008.

ARAÚJO, C. A. A pesquisa norte-americana. In: MARTINO et all (Orgs.) Teorias da Comunicação: conceitos, escolas e tendências. Petrópolis: Vozes, 2001.

A SENTINELA. A história da palavra de Deus na Espanha medieval. Número: $1^{\circ}$. de Março de 2014. p.12-15.Cesario Lange: Watchtower, 2014.

AUMONT, Jacques. O olho interminável - cinema e pintura. São Paulo: Cosac \&Naify, 2004.

BAZIN, A. O que é o cinema. São Paulo: Brasiliense, 2001.

BENJAMIM, W. A obra de arte na era de sua reprodutibilidade técnica. In: LIMA, L.C. Teoria da cultura de massa. São Paulo: Paz e Terra, 2000.

BENVENISTE, E. Problemas de linguística geral. Tomos I e II. Campinas: Pontes, 1995

BETTETINI, G. Semiótica, computação gráfica e textualidade. In. PARENTE, A. Imagem e máquina. A era das tecnologias do virtual. Trad. Rogério Luz etall. Rio de Janeiro: Editora 34, 1993.

BORELli,S. \& PRIOLLI,G (Coord.). A Deusa Ferida: por que a Rede Globo não é mais a campeã absoluta de audiência. São Paulo: Summus, 2000.

CALABRESE, O. A idade neobarroca. Trad. Carmen de Carvalho etall. Lisboa: Edições 70, 1999.

CLARK, W., PRIOLLI, G. O campeão de audiência. São Paulo: Editora Best Seller, 1991.

DEBORD, G. A sociedade do espetáculo. E-books Brasil.com: 2003.

DONNER, H. Hans Donner e seu universo. Rio de Janeiro: Salamandra, 1997.

DUARTE, E. Por uma epistemologia da Comunicação. In: LOPES, M.I.V. de.

Epistemologia da comunicação. São Paulo: Edições Loyola, 2003.

DUBOIS, P. Cinema, vídeo e Godard. Trad. Mateus Araújo Silva. São Paulo: Cosac Naify, 2004.

ELIAS, P.R. A transição entre o cinema mudo e o sonoro. Disponível em: 
http://webinsider.com.br/2012/03/14/a-transicao-entre-o-cinema-mudo-e-osonoro/. Acessado em 19 de dezembro de 2013.

FANUCCHI, M. Nossa próxima atração. O interprograma no canal 3. São Paulo: Edusp, 1996.

FIORIN, J. L. Semiótica e comunicação. In: PORTELA; DINIZ (Orgs.) Semiótica eMídia: textos, práticas, estratégias. Bauru: Unesp/Faac, 2008.

FLOCH, J-M. Identitésvisuelles. Paris: PresUniversitaires de France, 1995.

Alguns conceitos fundamentais em semiótica geral. Documentos de estudo do Centro de Pesquisas Sociossemióticas. São Paulo: Edições CPS, 2001.

FONTANILLE, J. Práticas semióticas: imanência e pertinência, eficiência e otimização. In: PORTELA; DINIZ (Orgs.) Semiótica e Mídia: textos, práticas, estratégias. Bauru: Unesp/Faac, 2008.

GREIMAS; COURTÉS, J. Dicionário de Semiótica. São Paulo: Cultrix, 1983.

GUIMARÃES, L. A cor como informação. A construção biofísica, linguística e cultural da simbologia das cores. $2^{a}$. Ed. São Paulo: Annablume, 2000.

As cores na mídia. A organização da cor-informação no jornalismo. São Paulo: Annablume, 2003.

HJELMSLEV, L. Prolegômenos a uma teoria da linguagem. São Paulo: Perspectiva, 1975.

JAKOBSON. R.Linguística e comunicação. São Paulo: Cultrix. Trad. IzidoraBlikstein e José Paulo Paes, 2007.

LANDOWSKI, E. De lastratégie, entre programmation et ajustement. Nouveaux ActesSémiotiques, n. 89-91. Limoges: Pulim, 2003.

LEVI-STRAUSS. Antropologia estrutural. $2^{\text {a }}$ ed. Rio de Janeiro: Tempo brasileiro, 1985.

LIMA, C. A gráfica televisual na área de produção de vinhetas: tv por assinatura $\mathrm{x}$ canais abertos. Trabalho de Conclusão de Curso. Design Industrial. Bauru: Unesp, 1997.

LIMA, C. A. S. A história da identidade visual da Rede Globo de Televisão. Dissertação (Mestrado em Design). Universidade do Estado do Rio de Janeiro, 2008.

LONGO JUNIOR, C. C. Design total: Cauduro Martino, 1967-1977. Dissertação. São Paulo, 2007.

LUCA, Walter de. Brasil: La televisiónavanzaconnuevas plataformas. In: VILCHES, L. Convergencia y transmedialidad. Barcelona: Gedisa, 2013, p.230-234.

MACHADO, A. A arte do vídeo. São Paulo: Brasiliense, 1997 
MACHADO, 2005. A televisão levada a serio. $4^{\mathrm{a}}$ ed. São Paulo: Senac, 2005.

MARTINO, L.C. et. All (orgs).Teorias da comunicação: conceitos, escolas e tendências. Petrópolis: Vozes, 2001.

MATTOS, D. J. L. Pioneiros do rádio e da TV no Brasil. 2004.

MATTOS, S. História da televisão brasileira. Petrópolis: Vozes, 2009.

MONT, C. G. El video: una revoluciónenlapalabra, enlaimagen y enlatelevisión. Comunicación y Sociedad, num. 10-11, septiembre-abril, 1991, pp. 209-224.

MORGADO, F. TV Excelsior: pioneira do design na TV. In: MORGADO, F. Almanaquetelevisionado. 2008. Disponível em: http://fernandomorgado.com.br/tag/cyrodel-nero/.Acesso em 12 de dezembro de 2013.

MOYA, A. Gloria in Excelsior. Ascenção, apogeu e queda do maior sucesso da televisão brasileira. São Paulo: Imprensa Oficial do Estado de São Paulo, 2004.

MUANIS, F. O caminho do olhar: entre as pinturas e as vinhetas de televisão. In: Significação: Revista de Cultura Audiovisual, $\mathrm{n}^{\circ}$ 35. Programa de Pós-graduação em Meios e Processos Audiovisuais/ECA-USP: São Paulo, 2011. ISSN 1516-4330.

OLIVEIRA, A. C. M. A. Sabor de Sabor: pão de açúcar, à luz da semiótica. In: $12^{\circ}$ Encontro Anual da Associação Nacional dos Programas de Pós-Graduação em Comunicação - Anais Compós. Recife, 2003.

OLIVEIRA, C. M. da. B. V. A construção discursiva da mulher brasileira em Retrato Falado, quadro humorístico do programa de televisão Fantástico da Rede Globo. Tese (Doutorado em Comunicação e Semiótica). Pontifícia Universidade Católica. São Paulo, 2009.

OLIVEIRA SOBRINHO, J. B. de. O livro do Boni. Rio de Janeiro: Casa da Palavra, 2011.

PEÑUELA CAÑIZAL, E. O texto fílmico entre a moldura e o enquadramento. In: Significação: Revista de Cultura Audiovisual, $n^{\circ}$ 38. Programa de Pós-graduação em Meios e Processos Audiovisuais/ECA-USP: São Paulo, 2012.

PIVETA, P.R. A evolução tecnológica como interferência na linguagem televisual: $o$ percurso da edição no telejornalismo da TV coroados. Dissertação. Londrina, 2010.

PORTELA, J.; DINIZ, M. L. V. P. (Orgs.) Semiótica e mídia. Textos, práticas, estratégias. São Paulo: Unesp/Faac, 2008.

RIBEIRO, C. dos S. Semiótica e tensividade: o fazer missivo, seus desdobramentos teóricos e modos de aplicação. Dissertação (Mestrado em Semiótica e Linguística Geral) Faculdade de Filosofia, Letras e Ciências Humanas. Universidade de São Paulo: São Paulo, 2008. 
SALleS, F. Bitolas e formados. Apostila de cinematografia. Disponível em: http://www.mnemocine.com.br/index.php/downloads/doc_download/5-capitulo-2-bitolase-formatos. Acesso em: 20 de outubro de 2013.

SCHIAVONI. J. Break comercial: estratégia e eficiência. In: PORTELA; DINIZ. Semiótica e mídia: textos, práticas, estratégias. Bauru: Unesp/Faac, 2008.

Vinheta televisiva: usos e funções. In: Significação - Revista de culturaaudiovisual. v. 38. n. 35. São Paulo, 2011.

SEMPRINI, A. A marca pós-moderna. Poder e fragilidade da marca na sociedade contemporânea. Trad. Elisabeth Leone. São Paulo: Estação das letras, 2006.

SILVA, P. A. do R. TV Tupi, a pioneira na América do Sul. Rio de Janeiro. Cadernos de Comunicação. Série Estudos. V. 12. Rio de Janeiro: Prefeitura da cidade do Rio de Janeiro - Secretaria Especial de Comunicação Social, 2004.

SILVA, J.C.P. et. all. O design diferencial de Aluísio Magalhães. In: Arcos Design. Vol. 5, n². Dezembro, 2010. ISSN 1984-5596.

SOUZA, J.C. A. de. Gêneros e formatos na televisão brasileira. São Paulo: Summus, 2004.

STAROBINSKI, Jean. As palavras sob as palavras: os anagramas de Ferdinand de Saussure. São Paulo: Perspectiva, 1974.

XAVIER, I. O discurso cinematrográfico: opacidade e transparência. São Paulo: Paz e Terra, $4^{\mathrm{a}}$ ed., 2008.

WILLIAMS, R. Technology and cultural form. New York: Schocken Books Inc, 1989.

WOLTON, D. Elogio do grande público. São Paulo: Ática, 2006.

ZILBERBERG, C. Razão e poética do sentido. Trad. Ivã Carlos Lopes e all. São Paulo: Edusp, 2006. 


\section{Apêndice I}

\section{Vinheta de TV: tipos, usos e funções}

Quando a Rede Globo despontou na década de 60, pode-se dizer que já havia um estágio bastante avançado de produção e utilização de vinhetas na televisão. Meu objetivo com este apêndice é apontar como o modo de representação das vinhetas foi se desenvolvendo ao longo do tempo a fim de compreender melhor o que a atuação da emissora promoveu em termos de técnica e estética audiovisual. Ao final, lançarei um olhar sobre a produção corrente das vinhetas na televisão como um todo, não somente na Rede Globo, abordando seus três aspectos gerais mais significativos: tipos, usos e funções.

Ao abordar tipos de vinheta me debruçarei sobre as diferentes propostas e, consequentemente, sobre diferentes produtos televisivos que, apesar de suas especificidades, conservam traços comuns, identitários, capazes de enquadrá-los sob uma mesma nomenclatura: vinheta. Considerar os usos - no passado e no presente - de produtos tão diversos leva-nos, por sua vez, a perceber esquemas de produção e veiculação que foram se desenvolvendo no decorrer do tempo e compõem hoje uma prática semiótica muito bem consolidada nessa máquina infindável de produção de sentido que é a televisão. Por fim, a análise acerca das funções da vinheta revelará "quem é quem" nos quatro cantos da telinha. Visto que esse tipo de produto esteve quase sempre à parte do roll de estrelas da programação, alguns se surpreenderão em ver como as vinhetas atuam sobre a estética televisiva.

Esta retomada deverá nos proporcionar ainda uma ideia de como um produto inicialmente descartável e improvisado, quase sem importância, acabou por se tornar o mais importante suporte de publicidade e propaganda da própria televisão.

\section{O experimentalismo da década de 50}

No Brasil, a primeira vinheta da televisão foi da Tupi. Ela apareceu no segundo semestre de 1950, quando a emissora iniciou suas transmissões ainda em caráter experimental, e ficou cerca de 3 horas no ar, das cinco da tarde às oito da noite. Tratava-se do pattern - ou desenho padrão - da Radio Corporation of America, utilizado para ajustar a imagem do equipamento RCA adquirido pela TV Tupi-Difusora bem como dos receptores 
domésticos (FANUCCHI, 1996, p. 33). Na parte central-superior da figura estava o índio bravo, símbolo da Tupi na época. A primeira vinheta da televisão brasileira foi, portanto, uma vinheta institucional. Mas, logo na sequência, a imagem que apareceu no monitor foi a de um letreiro com o título do primeiro programa da noite seguido de outro com os nomes dos participantes (Ibidem, p. 38).

Depois da inauguração, as vinhetas continuaram presentes em todos os intervalos da TV. E isso se deve a um fato bastante curioso: "além dos slides comerciais, exibidos sem qualquer texto falado e que permaneciam durante minutos no ar com música orquestrada em fundo, não havia outro recurso senão mostrar prefixos da emissora, alternando-se o letreiro de identificação formal com uma adaptação da logomarca (Ibidem, p. 74). Explicando melhor: o que acontecia era que os intervalos da televisão em sua primeira fase eram bem longos, e tecnicamente não era possível fazer com que isso fosse de outro jeito. Havia apenas um ou dois estúdios para todas as atrações e ao término de cada uma delas era necessário fazer mudanças no cenário, mexer na iluminação, reposicionar as câmeras - enfim, uma série de ajustes. E isso tudo demorava. Visto que os anunciantes eram poucos, o tempo de intervalo que sobrava para a televisão preencher era grande. E ela tratou de fazer isso anunciando a si mesma e a seus programas.

O modo como essas primeiras vinhetas eram produzidas variava de acordo com a importância do conteúdo e, principalmente, com a imutabilidade dele. Itens como o padrão de ajuste da imagem da TV e algumas vinhetas de identificação da emissora, que exigiam maior nível de qualidade e tinham por característica a repetição regular, sem alterações no conteúdo, podiam ser feitos em transparências, por meio de processo fotográfico, para serem projetados como slides. Mas visto que esse processo era bastante demorado e a televisão dessa primeira fase era marcada pelo improviso, as vinhetas de promoção dos programas eram desenhadas à mão, em cartões de papel que mediam $30 \times 40 \mathrm{~cm}$, e posteriormente filmadas. Esse era o único meio de garantir que os nomes dos artistas das próximas atrações, confirmados de última hora, apareceriam nos letreiros.

Esses visuais, em geral, eram descartados após o primeiro uso. Quando terminava um programa havia muita correria para montar o próximo e os letreiros iam parar no chão. Eram pisados, ficavam sujos e por isso tinham de ser refeitos no dia seguinte - com um grande prejuízo de tempo e acabamento, evidentemente. Com isso, os letreiros costumavam ser bem simples, porque eram sempre feitos na pressa do dia. Uma vez prontos, a "montagem" ou "edição" ficava a cargo de um assistente de estúdio que tinha, 
entre outras coisas, a responsabilidade de manipular os cartões diante da câmera.

Um aspecto interessante sobre essas produções é que, embora inicialmente a preocupação primária estivesse sobre o caráter imagético das peças, elas nunca iam ao ar sem locução e background, quer dizer, um som de fundo - geralmente exclusivo. A equipe que produzia a televisão era a mesma que antes - e até concomitantemente - trabalhava no rádio e a influência foi inevitável. Em termos de vinheta, associar o nome do programa ao do patrocinador, bem como o uso de slogans, jingles e a autopromoção por meio de chamadas são exemplos concretos nesse sentido. São estratégias que despontaram junto com o surgimento do rádio comercial na década de 30 e que, depois de se tornarem bem populares com essa mídia nos anos 40 - a chamada "Idade de Ouro" -, ajudaram a compor a linguagem da televisão na década de 50. Mário Fanucchi, que era locutor de rádio e veio a se tornar desenhista e posteriormente diretor de arte na televisão, explica:

Havia pouca especialização e a maioria dos radialistas exercia diversas funções. Essa versatilidade, como já ponderei em diversas ocasiões, talvez explique a razão de muitos artistas, profissionais de criação e técnicos não terem encontrado dificuldade maior na transição do rádio para a televisão. Através de persistente experimentação eles foram capazes de agregar o som - que dominavam - à imagem, e descobrir, aos poucos, uma linguagem própria para a televisão (FANUCCHI in SILVA, 2004, p. 54).

Voltando aos desenhos e imagens das vinhetas, um dos primeiros a se arriscar na produção desses visuais foi Álvaro de Moya. Conforme conta em depoimento (ALVES, 2008, p. 69; SILVA, 2004, p. 68; MATTOS, 2004), o recurso de letreiros de apresentação não havia sido pensado e programado com antecedência pela direção da emissora, a TV Tupi. Não havia planejamento, muito menos um procedimento definido. Pouco antes do primeiro deles ir ao ar, a única orientação existente havia vindo da equipe técnica:

"Como é que eu faço? Que tamanho devem ter os desenhos?", perguntei. Eles pegaram uma estante de música e disseram: "Você faz os desenhos, a gente os coloca aqui nesta estante e, depois, a câmera focaliza". (...) Aí, eles disseram: "Não use papel branco, porque a luz rebate muito". "Serve uma cartolina cinza?", perguntei. "Tudo bem", responderam. "Com 
letra preta?". "Tudo bem". Por fim, perguntei: E o tamanho?". Eles abriram a lente da câmera, tiraram suas medidas e definiram o tamanho que deveria ter cada cartão (MOYA in SILVA, 2004, p. 68).

E foi assim, com base nas limitações da lente de uma câmera, que se fixou o padrão visual dos primeiros cartões de identidade de programas da TV. Apesar do improviso, essa definição não teve nada de secundária. Estabelecer os limites da imagem foi fundamental para a televisão, tanto em termos estéticos como em termos de esquemas de produção. E a exemplo do que já acontecia no cinema, a dimensão do suporte de inscrição se tornou um dos primeiros materiais a ser levado em conta ao se produzir os conteúdos da tela pequena.

Nesse sentido, é difícil dizer se os desenhistas dessa primeira fase atuavam de modo consciente ao replicar o padrão estético do cinema clássico ao trabalhar a composição das imagens e a expressividade das letras e figuras, como a impressão de profundidade, iconicidade, entre outros. Todavia, assim como a pintura influenciou o cinema, o cinema também influenciou a televisão. E a noção de quadro parece ser o aspecto mais evidente dessa relação. Em primeiro lugar porque, definido os limites do suporte, a televisão sempre procurou fugir do perigo das bordas, optando pela centralidade da imagem. E, em segundo, pelo fato de que, investindo gradativamente numa estética figurativa de cunho icônico - "o fazer parecer real", como explicitarei ao longo desta retrospectiva - a televisão pôde, assim como o cinema, fazer o telespectador esquecer os limites das bordas e brincar com a imagem dentro de campo e seus prolongamentos fora dele.

O cinema também contribuiu para o desenvolvimento de vinhetas na televisão por ter sido pioneiro, em termos audiovisuais, em relação ao uso de letreiros. Primeiro com as legendas dos filmes mudos, depois com a apresentação de créditos nos vídeos. Visto que a apresentação da equipe costumava ser feita logo no início do filme e demorava alguns longos minutos, entediando a plateia, buscou-se acrescentar recursos audiovisuais que amenizassem o momento da espera. Foi aí que se começou a brincar com os desenhos das letras e a se utilizar imagens de fundo e figuras que contextualizassem a história por vir, preparando o público - processo que, posteriormente, se deu também com a televisão.

Esse tipo de proposta, no entanto, não nasceu com o cinema - embora ele tenha sido o primeiro a explorá-la articulando som e imagem - mas com as artes gráficas. O trabalho de logotipia ou design de letras, embora não tivesse propriamente esse nome, já existia desde a Idade Média e um dos seus usos mais comuns era na composição de uma peça 
visual chamada Iluminura, tida como o recurso visual das bíblias ilustradas nesse período $^{43}$. Como o nome indica, sua função era esclarecer ou tornar mais acessível o texto sagrado.

Em geral, as iluminuras eram compostas por três itens: o desenho de letras, especialmente as capitulares; o desenho de pessoas, animais, objetos e cenários, que costumavam narrar imageticamente o conteúdo do texto que acompanhava; e o desenho de estampas, majoritariamente florais, nas bordas da página, funcionando como uma espécie de moldura.

Estas últimas - e apenas elas - eram conhecidas como vinhetas. Esse nome, que significa pequena vinha, se deve ao grande valor simbólico que o vinho desempenha em certas passagens desses manuscritos sagrados ${ }^{44}$. Assim, muitas estampas representavam folhas de videira. Com o tempo, no entanto, a prática da iluminura se estendeu a outros tipos de conteúdos, ilustrando outros livros e, consequentemente, também se diversificou. O nome vinheta, porém, permaneceu devido ao uso já cristalizado e, no final, terminou como sinônimo de Iluminura - abarcando todos os elementos visuais e suas propostas figurativas.

Com os letreiros da televisão houve um processo similar. A ideia em torno da vinheta era que ela carregasse nomes, servindo de suporte para a divulgação do programa e dos artistas envolvidos nele. Os desenhos de que fala Álvaro de Moya ao contar sobre a elaboração das primeiras chamadas da TV eram, portanto, desenhos de letras. Daí que as primeiras vinhetas sequer eram chamadas assim, mas de letreiros. Como manda a composição tipográfica clássica, as fontes deveriam ser legíveis, visualmente atraentes, transmitindo ao telespectador o contexto do programa que anunciava. Um trabalho, sem sombra de dúvidas, poético porque se valia de formas, cores e texturas para transmitir todo uma gama de sentidos e sensações.

Tais letreiros passaram a ser acompanhados por imagens de fundo, inicialmente não-figurativas, e em pouquíssimo tempo já estavam dividindo o espaço central da tela com recursos figurativos e desenhos que, tal como na Iluminura, buscavam reproduzir visualmente o contexto da obra e envolver o público em sua atmosfera. Embora não

\footnotetext{
43 "Uma inestimável Bíblia ilustrada está guardada na Igreja de Santo Isidoro, em León, Espanha. Datada de 960 EC, ela possui 516 folhas, mede 47 centímetros e pesa 18 quilos. Outra Bíblia, atualmente na biblioteca do Vaticano, é a Bíblia Ripoll, datada de cerca de 1020 EC. Ela é uma das Bíblias mais ricamente ilustradas da Idade Média. Para produzir obras assim, um monge talvez levasse um dia inteiro para fazer uma letra inicial ou uma semana inteira fazendo a página de rosto" (A SENTINELA, 2014, p. 13).

${ }^{44}$ Em especial, a refeição noturna descrita em textos como 1Corintios 11:24 e Lucas 22:19,20.
} 
houvesse nesse período, por questões técnicas, um trabalho propriamente de vinheta, que a rigor seria uma espécie de desenho ornamental, figurativo ou não, sobre as bordas da imagem, o conjunto da obra, a exemplo do que aconteceu nas artes gráficas, passou a ser chamado de vinheta.

E que características tinham essa produções? Visto que eram feitas à mão sobre cartolinas e, posteriormente, em cartões de papel tipo canson - utilizando-se caneta ou pena cartográfica, nanquim e às vezes bomba de flit ou aerógrafo (por darem certo efeito pulverizado) - as vinhetas podiam contar com uma grande diversidade de técnicas próprias da pintura a fim de vencer o caráter planar do suporte e dar ao telespectador a ilusão de profundidade. Nesse sentido, entraram em jogo, principalmente, recursos como a perspectiva e o uso de luz e sombra. Desse modo, ao contrário do que talvez se possa pensar, os desenhos das primeiras vinhetas - tanto de letras como os de outros tipos - não eram totalmente chapados, mas projetados com alguma profundidade.

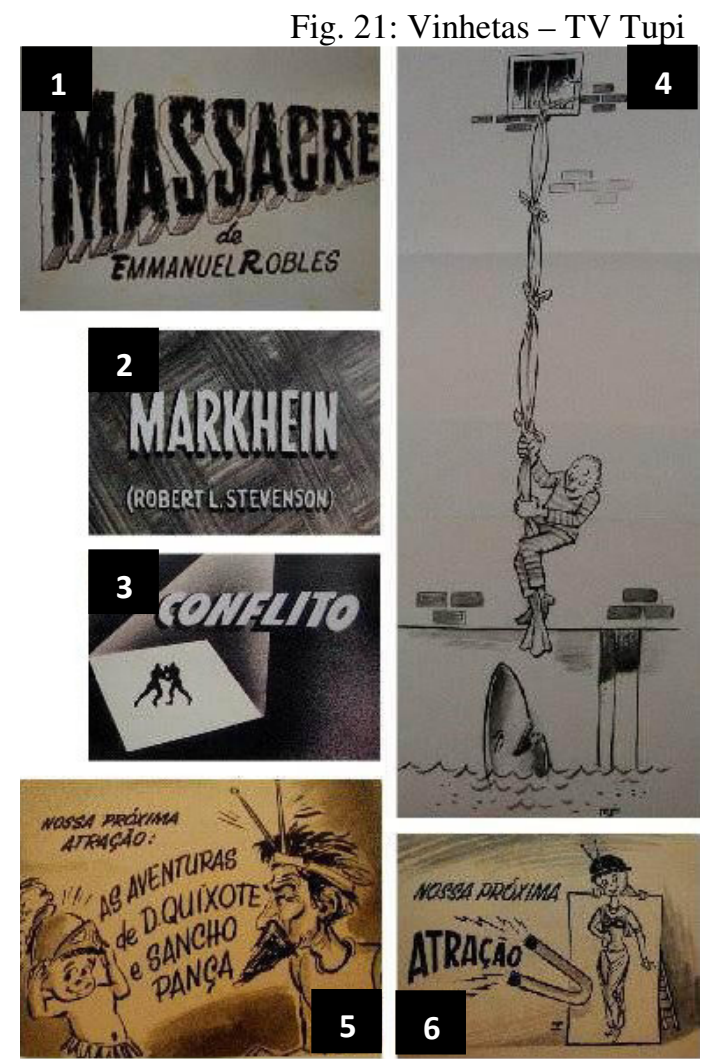

1 - Letras projetadas em perspectiva.

2 - Letreiro e textura de fundo.

3 - Letreiro e imagens figurativas de cunho icônico.

4 - Experimentação vertical de entrada e saída de imagens.

5,6 - Utilização de mascote, símbolo institucional que resultaria no papel identitário desempenhado posteriormente por logomarcas.

(FANUCCHI, 1996, p.49, 52, 54, 86, 90, 105) 
Nesses primeiros anos da Tupi, dado o próprio desenvolvimento ainda incipiente da linguagem da televisão como um todo, não havia uma tipologia em relação às vinhetas, tão pouco uma delimitação clara em torno dos conteúdos a serem trabalhados - institucionais e promocionais de programas, por exemplo. De modo que é possível encontrar vinhetas que mesclassem as duas propostas e peças que serviam apenas para amenizar o tempo de espera, sem qualquer menção institucional ou de programação, como a panorâmica vertical criada por Fanucchi (fig. 21/4) - em que um presidiário tenta escapar da cadeia e se depara com um tubarão. Todavia, esta é uma peça diferente e mostra-se bastante especial por refletir a experimentação estética da época:

\begin{abstract}
Imaginei como seria instigante para o telespectador descobrir o significado de um desenho revelado lentamente e por partes no vídeo. Precisaria ser um desenho desenvolvido verticalmente, mas de forma que seu layout inusitado se justificasse; ou seja, a representação de algo que estamos habituados a percorrer com os olhos enquanto baixamos ou erguemos a cabeça, ou cuja apresentação gradual sugira essa maneira de ver as coisas. Em suma, uma 'panorâmica vertical' em que a figura vai-se desdobrando pouco a pouco diante dos olhos. (...) Mas e o conteúdo dos desenhos? $\mathrm{O}$ que iriam transmitir? Bem, teria de ser algo leve, engraçado ou irônico (FANUCCHI, 1996, p. 101).
\end{abstract}

Panorâmicas como essa eram apresentadas em diferentes intervalos, de maneira que as imagens se complementavam como "uma história em quadrinhos revelada por partes", como definiu o próprio Fanucchi - o que evidencia, também, a influência desse tipo de arte sobre a linguagem da televisão ${ }^{45}$. Segundo ele, "as possibilidades da 'Panorâmica Vertical' foram exploradas tanto com desenhos como com letreiros, nos quais o formato peculiar, em vez de representar uma limitação, constituía um fator positivo em termos de originalidade" (1996, p. 103). Essas experiências, como se pode imaginar, caminharam no sentido de constituir ou mesmo ampliar e tornar mais complexa a narratividade visual que existia nas vinhetas até então.

\footnotetext{
${ }^{45}$ Desde tais aparições na Tupi, a linguagem dos quadrinhos foi amplamente utilizada na produção de vinhetas, sobretudo em forma de charge. Essa palavra, de origem francesa, significa carga e remete a um abuso ou exagero ao retratar traços físicos de alguém ou de algum objeto. Assim, é um estilo que tem por finalidade a sátira de pessoas, coisas ou eventos.
} 
De fato, nessa época, apesar das imagens serem estáticas e de algumas vinhetas serem produzidas a partir de peças unitárias e autossuficientes, elas já começavam a ser pensadas dentro de uma lógica sequencial. E esse esquema ganhou muito força com a chegada do Gray-Tellop, um projetor de opacos que permitia alternar mecanicamente os cartões - que passaram a ter 8 x $11 \mathrm{~cm}$ de área útil - e a fazer também o corte e a fusão entre as imagens de um desenho e outro. Como a grade do projetor comportava até cinco cartões a apresentação das vinhetas começou a ganhar mais ritmo e esse dinamismo, somado ao efeito de fusão que o projetor possibilitava, deu a elas um caráter bem mais atrativo.

Havia sempre duas dessas longas lâminas - ou 'pentes' - que comportavam cinco desenhos cada, de modo a permitir a projeção alternada dos visuais de uma e de outra fileira através do Gray-Tellop. Fazendo deslizar os 'pentes' em trilhos colocados em diferentes níveis diante da lente da câmara de filme, o operador ia expondo os letreiros o tempo suficiente para permitir sua leitura (FANUCCHI, 1996, p. 76).

Fig. 22: As grades do graytellop
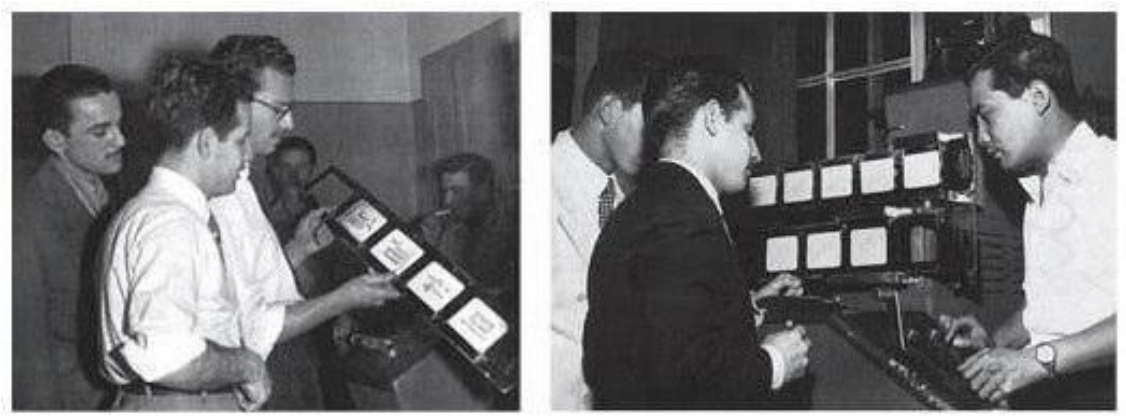

(ALVES, 2008. p.94)

Mas os resultados nem sempre eram satisfatórios. O aparelho doméstico de televisão necessitava de ajustes - vertical e horizontal, de brilho, contraste, foco - que deviam ser feitos por técnicos, tendo como referência o padrão de imagem dado pela própria emissora. Só que na maioria dos casos era o telespectador quem fazia tais alterações e, em consequência, era comum a imagem ficar distorcida, desfocada, com excessivo contraste e ausência quase total de tons de cinza, o que gerava fantasmas na tela. Em vista disso, a equipe de produção teve de reformular todo o visual da TV - desde elementos de cenário a itens de vestimenta - restringindo o uso acentuado das cores branco 
e preto. De modo que "os elementos mais escuros passaram a ser pintados de cinzachumbo, enquanto os mais claros receberam o tom gelo" (FANUCCHI, 1996, p. 109).

No tocante às vinhetas, os desenhos passaram a ser feitos com nanquim diluído em água, a fim de obter diferentes tons de cinza. Posteriormente, no entanto, viu-se que a coloração dos desenhos se mostrava muito mais eficaz para esse propósito, garantindo na tela uma diversidade bem maior de meios-tons. Outra coisa que também mudou foi a margem de segurança dos cartões, que aumentou de tamanho a fim de que as bordas dos desenhos não fossem cortadas pelos televisores mal regulados.

Todos esses elementos que abordei até aqui - o uso da perspectiva, o trabalho com luz e sombra, a ilusão de movimento, as adaptações para a nitidez da imagem, a coloração dos desenhos e a segurança com o tamanho das margens, além das próprias imagens cujos motivos buscavam ser cópias do mundo natural - refletem a preocupação da televisão em construir a estética figurativa de cunho icônico que mencionei anteriormente.

Tal estética tem a ver com um tipo de representação imagética que busca, em cada detalhe, retratar os objetos da cena como se fossem mesmo os objetos do mundo natural. Não é a toa que, posicionados na tela, mesmo os primeiros cartões fizessem o olhar do telespectador viajar no eixo "Z", como acontece com os objetos ao serem captados pela retina. O segredo aqui é que todos esses elementos contribuem para um efeito de profundidade de campo, que é próprio do olho humano. Quanto mais bem feito é o trabalho de utilização desses recursos no quadro, maior é a verossimilhança e maior é a chance de que o telespectador se esqueça das bordas. Quando isso acontece, o efeito de realidade é tão grande que a imagem representada chega a ter o valor da imagem real e o ato de ver televisão se torna tão pessoal quanto a escolha de quem vê o mundo diretamente com os próprios olhos.

Toda a televisão caminhava nesse sentido. Para firmar-se como novo meio, optava por uma linguagem verossímil, uma estética que fizesse referência às coisas do mundo natural, produzindo a ilusão de verdade necessária para dar força e credibilidade às imagens da tela. Esse processo, coerentemente, se estendeu também às vinhetas, de modo que algumas delas - em geral, as que anunciavam atrações não rotineiras, nas quais se costumava utilizar ideias mais ousadas e recursos técnicos mais avançados - chegaram a ser feitas "com cenas gravadas em 16 mm, com o áudio sendo acoplado no momento da transmissão por meio de gravação em disco de acetato"(FANUCCHI, 1996, p 188). 
Esse foi um grande avanço na produção de vinhetas porque até então as chamadas obedeciam a um "formato muito próximo ao radiofônico, em que predominava a voz do locutor e a imagem se resumia num 'GT' com o título, o dia e o horário da apresentação" (Ibidem). Agora, no entanto, elas dispunham de um material que, indo além do registro automático que a fotografia já fazia, tinha a graça do movimento.

Um dos aspectos técnicos da bitola 16 mm, como já adiantado na citação de Mário Fanucchi, é que ela originalmente não tinha som. Como era perfurada dos dois lados, não havia espaço suficiente para a banda sonora, razão pela qual os sons precisavam ser acoplados posteriormente. Esse modelo de sonorização, predominante na televisão na década de 50, é conhecidos como "sound-on-disc", que significa captura direta em disco.

Finalizar um filme desse tipo exigia grande esforço artesanal, de forma que as vinhetas em $16 \mathrm{~mm}$ nem sempre tinham os sons perfeitamente sincronizados com as imagens. E como os fotogramas eram puxados pelos orifícios laterais por uma correia dentada era comum o telespectador ver no monitor uma imagem ligeiramente trêmula (PIVETA, 2010). Se isso constituía uma perda em termos visuais, ganhava-se, por outro lado, com as possibilidades narrativas e efeitos especiais que os diversos tipos de plano de filmagem, movimentação de câmera, montagem e edição passaram a permitir. Apenas posteriormente - na década de 60 e, em especial, na década de 70 - começou-se a utilizar o chamado "sound-on-film" ou gravação de som em película. Nesse processo, o som era gravado opticamente na parte lateral do filme, num compósito fotografia-trilha sonora, o que impedia a perda de sincronismo no processo de edição quando o filme precisava ser cortado e emendado (ELIAS, 2012).

De modo geral, apesar de apresentar uma qualidade de imagem inferior, com uma área útil cerca de quatro vezes menor que a película standard, a bitola de $16 \mathrm{~mm}$ servia perfeitamente ao formato 4:3 (ou 1:33) da televisão. Visto que "o objetivo era a projeção numa pequena tela de 14 polegadas, não havia necessidade de se utilizar do $35 \mathrm{~mm}$ (SALLES, 2013, p 4). Os equipamentos e câmeras para filmes em 16 mm eram também menores e mais leves, dando maior agilidade às produções. Todavia, o uso de filme para produção de vinhetas era bastante restrito. Apesar de ser mais barata que a película de 35 $\mathrm{mm}$, a bitola de $16 \mathrm{~mm}$ também era importada e cara. Com isso, as cenas gravadas apareciam apenas esporadicamente na televisão, deixando espaço para as vinhetas desenhadas com técnicas de animação quadro-a-quadro. 


\section{Os desenvolvimentos de linguagem na década de 60}

Nesse tipo de produção, as imagens são projetadas uma a uma, com progressão de movimento. E naquela época, em diversas emissoras, eram feitas primeiramente em cartões de papel, depois fotografadas, reveladas e transformadas em slides. A projeção sequencial e temporalmente uniforme entre um quadro e outro era o que gerava a ilusão de movimento. E foi a TV Excelsior quem mais notadamente utilizou esse recurso - basta lembrar as chamadas feitas com os bonecos Paulinho e Ritinha. Esses dois mascotes foram criados por Ruy Perotti a pedido de Edson Leite que, ao assumir a emissora de Mário Wallace Simonsen, buscava esquemas de maior aproximação com o público.

Esses bonequinhos representavam crianças de 6 ou 7 anos e eram veiculados (em filmes de animação ou slides) para informar a hora certa, a temperatura, as próximas atrações e pedir desculpas quando algum defeito técnico tirava a emissora do ar. Com o tempo, essa comunicação aumentou para saudar datas festivas e cívicas, campanhas beneficentes e serviços de utilidade pública. Tornando-se o principal logotipo da emissora, os bonequinhos apareciam na programação da imprensa, nos comunicados oficiais, nas propagandas e nos equipamentos e viaturas. Outra de suas funções era chamar a atenção do público para as principais atrações que seriam apresentadas em outros horários (ou dias), com o objetivo de mantê-lo na Excelsior (AMORIN in MOYA, 2010, p. 196).

Tais bonequinhos animados conseguiram cativar o público e fizeram muito sucesso, sendo utilizados em diversos tipos de abordagem, entre eles, a vinheta de passagem que, segundo Furtado (1988, p. 62 apud MATTOS, 2009, p. 86), foi uma modalidade criada pela Excelsior. Conforme segue narrando Amorin, "também no Rio de Janeiro, meses mais tarde, eles [os bonequinhos] foram utilizados pela Excelsior e logo copiados pela TV-Rio, Canal 13, a grande rival", de modo que em 5 de outubro de 1963 a Revista do Rádio publicou uma nota intitulada "A Guerra das Vinhetas":

As emissoras de televisão fizeram uma grande descoberta: que são, realmente, importantes veículos de publicidade e que promovendo vendas, podem promover-se também...Pelo menos duas tevês do Rio estão sapecando vinhetas publicitárias de seus programas e 
dizendo-se, cada qual, a melhor... A TV Rio manda que os telespectadores fiquem no seu canal, porque têm filmes, shows e bom humor. A TV Excelsior não deixa por menos. A guerrinha está ficando ótima. Lembra aquela história dos três salões de barbeiro numa mesma rua. $\mathrm{O}$ primeiro botou um cartaz na porta: o melhor do Brasil. O outro sapecou uma tabuleta: o melhor do mundo. O terceiro foi mais objetivo: o melhor barbeiro desta rua. Será que a TV Tupi-Rio, como terceira parte nessa luta, vai criar uma vinheta desse gênero? (AMORIN in MOYA, 2010).

A força que as vinhetas tinham havia despontado logo no início das transmissões da Tupi, motivo pelo qual começaram a ser inscritas como bonificação nos contratos de patrocínio das emissoras dos Diários Associados - nessa época, era comum as atrações da televisão levarem o nome do patrocinador. (FANUCCHI, 1996, p. 189; ALVES, 2008, p. 93). Tal prática já havia tirado o caráter aleatório dessas produções e as valorizado comercialmente, mas foi com o acirramento entre as emissoras que se começou a sentir na pele o poder da vinheta como instrumento de comunicação e dos benefícios de utilizá-la não só sistematicamente, mas também de modo estratégico aplicando seus recursos de imagem e som tanto dentro como fora da televisão - em documentos oficiais, identificação de carros, prédios e inserções comerciais em veículos como o rádio e o jornal.

Sendo assim, voltando às vinhetas da Excelsior, o que elas tinham de tão especial a ponto de, como disse Amorin, terem seu modelo copiado pela concorrência? JulioMedaglia dá a pista e mostra que o segredo não estava só nos bonequinhos:

os primeiros dez anos da TV brasileira, liderados em todos os sentidos pela TV Tupi de Chateaubriand, foram efetivamente de festa. Todo o brilho mágico de nosso rádio acrescido da imagem em movimento ganhava dimensão ainda maior. No início dos anos 1960, porém, um novo fenômeno aconteceu em nossa TV que a todos surpreendeu. Todo aquele know-how adquirido na primeira década fora assimilado por uma nova emissora que surgia, só que de seu mecanismo fazia parte um novo repertório de ideias e profissionais que deram um sentido inteiramente diferente ao veículo (MEDAGLIA in MOYA, 2004, p. 116). 
Desse novo repertório de ideias e profissionais do qual nos fala Julio Medaglia fazia parte Cyro del Nero, um artista brasileiro que acabava de chegar da Europa e que, convidado a ser diretor de arte da Excelsior, decidiu implantar um jeito novo de produzir imagens na TV:

criei um departamento de comunicação visual para a emissora. Minha primeira decisão foi: aqui ninguém desenha. Surgiu meu primeiro assistente, o Tide [Hellmeinster]. E a ordem foi essa: você está proibido de desenhar. Você tem aqui cartões pretos e brancos, uma tesoura, uma régua e um estilete. Corte e cole, faça montagens (NERO in MOYA, 2004, p. 112).

Conforme explica Amorin, os cartões da Excelsior mediam 50 x $35 \mathrm{~cm}$ e eram "recortados conforme a figura que se necessitasse. Eram cortados em silhuetas, montados um em cima do outro a sugerir filigranas, num desenho geometrizado" (AMORIN in MOYA, 2004, p. 159). Em seguida, eram "levados para o laboratório fotográfico, fotografados e revelados até chegarem à tonalidade que se pretendia e depois transformados em slides para serem utilizados pelo projetor do telecine" (ibidem).

O resultado desse trabalho foi tão bem recebido pelo público que a Excelsior passou a contar com um desenho inteiramente em preto e branco, cuja característica era ser duro, ultra contrastado, sem meios tons. Um tipo de imagem que conseguia transmitir muita força no vídeo. Visto que a tecnologia da TV havia avançado a ponto de suportar agora esse uso acentuado das cores branco e preto, a Excelsior parece ter sido a primeira e mais bem-sucedida emissora a tirar proveito dela. Com isso, o estilo acabou criando o primeiro programa de identificação visual de uma rede de televisão no Brasil - que, indo além dos vídeos institucionais ou de promoção de programas, abrangia a produção de cenários, iluminação, indumentária etc. Quem passasse pela imagem da Excelsior era capaz de reconhecê-la e reconhecer também uma qualidade e modernidade que não existiam em outras emissoras (ibidem).

Nesse aspecto, deve-se ressaltar também que a Excelsior foi a primeira a se valer de uma padronização da marca por meio de logotipos, com a Helvética do suíço Max Bill uma fonte sem serifa, de boa legibilidade, bastante popular no mundo todo e comumente associada ao modernismo do design gráfico (ibidem; MORGADO, 2008; PIVETA, 2010).

De acordo com Longo Junior, esse movimento, "através dos seus representantes e seguidores, se auto-atribuiu a insígnia moral do 'bom desenho'- ordem, rigor geométrico, 
precisão e simplicidade formal ligada à função" - e se consolidou no Brasil "entre a abertura do Instituto de Arte Contemporânea (1951) e a Escola Superior de Desenho Industrial (1963)" (2007, p. 68).

Não é de admirar, portanto, que os princípios norteadores do design moderno tenham orientado também as produções da televisão desse período em diante. Um aspecto que chama a atenção é que, segundo Cardoso, "surgiu nessa época, não o design propriamente dito - ou seja, as atividades projetuais relacionadas à produção e ao consumo em escala industrial -, mas antes a consciência do design como conceito, profissão e ideologia" (CARDOSO, 2005, p. 7 apud LONGO JUNIOR, 2007, p. 68). Sob forte influência desse contexto, houve uma crescente profissionalização do design gráfico nas emissoras, e equipes e departamentos especializados começaram a ser criados.

Além da técnica da colagem, outro recurso de produção que despontou na década de 60 foi o videoteipe ${ }^{46}$. E com ele a televisão viveu uma verdadeira revolução. As fitas magnéticas permitiam gravar e apagar os conteúdos diversas vezes, coisa que não era possível com os filmes utilizados até então. Em decorrência disso, a televisão deu um grande salto de qualidade: os erros já não iam mais ao ar e os programas podiam ser gravados com antecedência, o que permitiu ou mesmo fortaleceu o conceito de rede de televisão, padronizando a programação que havia em diferentes estações de uma mesma empresa; também favoreceu, com essas novas atrações - que agora podiam ser veiculadas todos os dias em horários rigorosamente programados - a grade horizontal da televisão e a consequente fidelização do público (MATTOS, 2009, p. 87,121; PARTITI in MOYA, 2004, p. 65-66).

Em outros termos, o videoteipe foi fundamental para que a televisão se estruturasse como empresa industrial. Apenas para se ter ideia, com a possibilidade de comercializar as atrações e espalhar os programas pelo Brasil afora, foram inauguradas 27 emissoras - cuja maior parte da programação, cerca de $80 \%$, exibia produções do eixo Rio-São Paulo. Tudo em VT (AMORIN, 2008, p. 25).

Tal ferramenta prometia ser também "o grande incentivador técnico de uma nova linguagem artística para a televisão"(ibidem, p. 26) - e isso realmente aconteceu. Segundo Mont, "das tecnologias da informação surgidas no último terço do século XX, o vídeo

\footnotetext{
${ }^{46}$ Segundo Partiti, "os VTs apareceram por aqui naqueles famosos quadruples, uns monstros do tamanho de uma sala. Para ter uma ideia, a edição era na base da gilette, a fita era cortada, sem que se visse a imagem, a olho, e emendada" (PARTITI in MOYA, 2004, p. 65-66).
} 


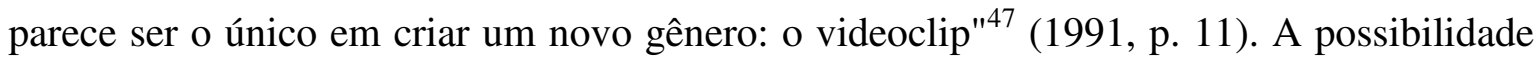
de explorar diferentes relações de sentido entre som e imagem, e a liberdade para compor novas estruturas narrativas a partir de avançados recursos de edição fez dessa ferramenta de trabalho "a estrutura ideal para fomentar o terreno da experimentação"48 (MONT, 1991, p. 11) que a televisão precisava para se desenvolver em termos de linguagem.

De acordo com Arlindo Machado, o fato de o videoclipe ser uma produção curta e de custos relativamente baixos ajudou nessa empreitada, transformando-o no que o autor definiu como o "gênero mais genuinamente televisual", capaz de "dar continuidade ou novas consequências a atitudes experimentais inauguradas com o cinema de vanguarda dos anos 20, o cinema experimental dos anos 50-60 e a videoarte dos anos 60-70" (2005, p. 173). Assim, dentre as principais características do videoclipe, conforme seu desenvolvimento e amadurecimento ao longo do tempo, estão" o abandono ou a rejeição total das regras do 'bem fazer' herdadas da publicidade e do cinema comercial" e a busca por uma "nova visualidade, de natureza mais gráfica e rítmica" (ibidem).

Conforme analisa Philippe Dubois, essa estética ou linguagem videográfica - que ganhou no início dos anos 70 a qualidade da cor - esteve alicerçada fundamentalmente na mixagem ou mescla de imagens, utilizando para isso recursos como a sobreimpressão, com imagens translúcidas, umas sobre as outras, formando camadas na tela; janelas a partir do recorte e justaposição de fragmentos de planos distintos no mesmo quadro; e a incrustação ou efeito chroma-key, que Dubois julga ser a técnica mais específica da imagem eletrônica uma vez que trabalha com a separação de partes da imagem a partir da crominância ou luminância do próprio sinal do vídeo, de modo que os pedaços recortados e vazados podem ser preenchidos ou substituídos por outras imagens (2004, p. 78-83).

Lança-se, portanto, uma estética na contramão do processo a que vinha se submetendo a televisão. A imagem na tela já não é mais singular, nem homogênea e tão pouco fundada sobre um mesmo ponto de vista - tornando difícil ou mesmo impossível falar em efeitos de realidade, como a profundidade de campo. $\mathrm{O}$ fato é que depois do videoteipe os trabalhos mais artísticos na televisão - e isso inclui certas vinhetas caminharam basicamente em dois sentidos: 1) a descaracterização do referente, bem como a quebra do fluxo, da continuidade dos planos e das narrativas; e 2) a exacerbação ou

\footnotetext{
${ }^{47}$ Tradução livre. No original: "de las tecnologias de información surgidas en el último tercio del siglo XX, el vídeo parece ser el único en crear un nuevo género: el videoclip" (1991, p. 11).

${ }^{48}$ Tradução livre. No original: "la estructura ideal para fomentar el terreno de la experimentación" (MONT, 1991, p. 11).
} 
intensificação dos elementos sensoriais que compõe os sujeitos e objetos na tela. Tanto num caso como no outro, o resultado já não refletia a busca pela mimese que existia até então. O efeito passava a ser, respectivamente, de "irrealidade" e "hiper-realidade".

\section{O novo paradigma de figuração da década de 70}

A computação gráfica, que começou a aparecer na televisão década de 70 representou um grande avanço na composição deste último - e atual - quadro estético. Segundo Bettetini, "a imagem da computação gráfica mexe com o tratamento de qualquer produção icônica tradicional: visto que não reproduz um objeto real, ela perde a referência ao exterior, o que é típico de qualquer signo" (in PARENTE, 1996, p. 68). Assim, nessa nova técnica de figuração a imagem deixava de ser captada pela lente de uma câmera para ser produzida a partir de procedimentos lógico-matemáticos, podendo se desvincular do real e das leis que o regem. Com isso, abriu-se um enorme campo de possibilidades visuais que foram, diga-se de passagem, muito bem aproveitadas pela televisão. Arlindo Machado explica em mais detalhes os estágios de desenvolvimento dessa nova técnica:

A época de ouro de introdução do grafismo digital na televisão corresponde ao período de 1975 a 1981, ocasião em que a computação gráfica, malgrado ainda produzida em máquinas de grande porte e muito caras, desenvolveu o essencial de seus algoritmos de processamento, modelação, animação, iluminação e texturização. O período seguinte, a partir de 1982, é caracterizado por alguns autores, por exemplo, Morse, como a fase barroco/maneirista do desenho gráfico para televisão, quando predominaram as mais sofisticadas coreografias baseadas em simuladores de voo $\mathrm{e}$ as estonteantes metamorfoses de imagens, cujo exemplo mais conhecido é a abertura futurista do programa de variedades Fantástico, criada em 1983 por Hans Donner para a Rede Globo brasileira e produzida pela empresa norte-americana Pacific Data Images. O passo seguinte seria dado pela rede de cabo MTV, empresa estabelecida em 1981, que encomendaria seus logos a artistas gráficos e plásticos de reconhecido prestígio. (...) Fugindo do padrão geométrico e clean imposto pela computação gráfica tradicional, a rede musical norte-americana preferiu, até mesmo para se diferenciar das outras redes, investir em propostas mais sujas e mais 
underground, resgatando inclusive o desenho bidimensional, como nos primórdios da televisão (2005, p. 201-202).

É bastante emblemático que o autor tenha utilizado a Rede Globo e a Music Television ao abordar os estágios de desenvolvimento ou formas de uso do computer graphics na televisão brasileira. Em primeiro lugar porque são emissoras de referência que sustentam propostas editoriais bem distintas, pertencendo a primeira ao broadcasting e a segunda ao narrowcasting. Em segundo, porque tal posicionamento conduz à manutenção de dois estilos ou estéticas também bastante diferentes que, valendo-me das proposições de Omar Calabrese (1999), podem ser reconhecidas, respectivamente, como clássica e neobarroca - termos que, de certa formam remetem ao padrão "geométrico-clean" e à característica "barroco-maneirista" apontados por Machado e Morse na citação anterior.

Já explico. Embora a década de 80 e todo o período sequente tenha sido, de fato, marcada como uma fase "barroco/maneirista" não se pode perder de vista que uma afirmação desse tipo se projeta sempre sobre o caráter geral das produções e, especialmente, sobre o que desponta com relativa força em termos de linguagem. Mas isso, de maneira alguma, significa que todas as produções se encaixam completa e perfeitamente no paradigma emergente. Daí considerar a coexistência dos dois estilos, sendo um predominantemente clássico e o outro neobarroco. Além disso, tal definição leva em conta um produto bastante específico dentro da grade televisiva, que é a vinheta institucional de ambas emissoras - foco sobre o qual recaem as considerações que seguem.

O que significa, então, os termos clássico e neobarroco? Segundo Calabrese, estes devem ser tomados como "constantes formais", "modelos morfológicos", "formas de gosto". Dentro do primeiro estilo estão os fenômenos de ordem, estabilidade e simetria. No segundo, os de desordem, instabilidade e assimetria. São, evidentemente, modelos opostos e, de certa forma, em competição, considerando-se que "todo fenômeno clássico surge por manutenção do sistema perante as mais pequenas perturbações" enquanto "todo fenômeno barroco surge justamente por 'degeneração' (desestabilização) de um sistema ordenado" (1999, p. 206).

É com vistas a essa conceituação que se pode atrelar a Rede Globo a um estilo clássico e a MTV a um estilo neobarroco. No primeiro caso, apesar das experimentações a partir da computação gráfica - como as "coreografias baseadas em simuladores de voos e as estonteantes metamorfoses de imagens", prevalece o caráter ordenado, simétrico e bem 
regulado das figuras na tela - lembrando que a principal característica das vinhetas da Globo, sob a marca deixada por Hans Donner, é a tridimensionalidade e esta nada mais é que a manutenção de um efeito de realidade. Já no segundo, tudo isso se perde, dando lugar a uma imagem ruidosa e esquizofrênica.

O que talvez nos leve a compreender melhor a dinâmica dessas duas emissoras está no que Calabrese explicita como limite e excesso:

um limite é um confim de valores de um 'contorno' em que todos os pontos gozam da mesma função. Se, pois, se abate o limite, com isso mesmo se eliminará o contorno, ou ser-lheá criado um outro. Cada pressão na direção do limite tem, pois, o valor de uma tensão (...) $\mathrm{O}$ excesso manifesta a ultrapassagem de um limite visto como caminho de saída de um sistema fechado (1999, p. 63).

Conforme o autor continua em sua análise, o fato de haver um "perímetro" ou "limite" implica necessariamente a existência também de um "centro". Todavia, este centro pode coincidir ou não com o meio, gerando o que Calabrese chamou de sistemas centrados e sistemas descentrados - e, neste último caso, vale a semelhança com os confins geopolíticos: "quando um Estado coloca a sua capital perto da fronteira, ou ainda não se deu uma ordem central, ou então tem veleidades expansionistas, e o centro descentrado de hoje é uma projeção de um centro central no futuro" (1999, p. 62-63). Com isso em mente, a Rede Globo aparece, grosso modo, como um sistema descentrado que, apesar de tencionar a elasticidade do contorno, simplesmente não o rompe, colocando-o apenas "um pouco mais para lá". A MTV, por outro lado, excede o perímetro tanto na forma como no conteúdo, colocando o sistema anterior em crise

Mas o que isso pode ter a ver com o caráter broadcast ou narrowcast de uma emissora? É simples. Como se sabe, a televisão broadcast é do tipo geralista. Portanto, não somente é feita para todos os tipos de público, como, principalmente, precisa do total dessa audiência. Nada mais compreensível então que, para firmar-se, trabalhe sua identidade audiovisual na "universalidade do clássico". De acordo com Calabrese,

não só existe a forma do clássico, mas a qualquer um tal forma agrada, e precisamente em contraposição com as morfologias irregulares e instáveis, que chamamos 
'neobarrocas'. Poderemos também interrogarnos sobre o porquê de tanto êxito, visto que não é defensável atribuí-lo apenas a uma organização do consenso por parte do poder. E a resposta é uma só: o mesmo afastamento do equilíbrio do sistema social, se por um lado, favorece o aparecimento de corpos irregulares, justamente por isso provoca, por outro lado, também paralelos desejos de estabilidade (1999, p. 199-200).

Já a MTV, como uma televisão de tipo narrowcast, voltada especificamente para o público jovem, pode se valer desta condição para explorar recursos visuais tão rebeldes quanto é potencialmente o seu telespectador. Afinal, como bem coloca Cristina Lima, "se a programação de cada canal é destinada a um público específico, então seu padrão visual também deverá ser personalizado de acordo" (1997, p. 8).

Essa problemática em torno do público alvo tanto nas televisões broadcast quanto nas narrowcast pode até ser considerada relativamente nova quando o que se leva em conta é o surgimento da comunicação de massa e seus objetos. Porém, do ponto de vista da linguagem, para onde resvala de fato todo fenômeno comunicacional, a questão não é exatamente nenhuma novidade, e há tempos já apontava como saída as teorias da enunciação por demonstrar que o público é sempre um "co-enunciador". Segundo Benveniste (1995), a enunciação é a instância do ego, hic et nunc. De modo que "o eu e o tu são actantes da enunciação, os participantes da ação comunicativa. Ambos constituem o sujeito da enunciação, porque o primeiro produz o enunciado e o segundo, funcionando como uma espécie de filtro, é levado em consideração pelo $e u$ na construção do enunciado" (FIORIN, 2008, p. 78).

A atualização ou adaptação dessa teoria aos meios massivos e mais especificamente à televisão é que nela tanto o eu-enunciador como o tu-enunciatário passam a ser coletivos - e, em certo sentido, homogêneos. Isso se diz porque, no primeiro caso, toda marca individual - de roteiro, iluminação, direção, interpretação, etc. - tende a esmaecer a fim de que o resultado seja "um todo de sentido". E, no segundo, no âmbito da recepção, toda a vasta audiência tende a ser reduzida ao menor denominador comum no caso da televisão aberta ou então ao tipo ideal no caso da televisão segmentada.

Isso significa que o caso MTV é, sem dúvida, muito particular. A emissora cria uma imagem de rebeldia para o seu público-alvo e este, ao aceitá-la, reforça o tipo ideal gerando um looping. Mas, evidentemente, a estética neobarroca não pertence neste caso ao 
caráter narrowcast da televisão, mas está atrelada ao próprio segmento em questão e ao tipo ideal criado para ele. Fosse um público diferente, o tipo ideal talvez obedecesse a padrões mais próximos a uma estética "clássica" do que "neobarroca". O tipo segmentado, portanto, não obriga a realização de voos estéticos mais livres, apenas os permitem.

Assim, o mais comum é que televisões segmentadas construam projetos gráficos em cima de uma figuratividade igualmente específica - que pode se voltar tanto para uma determinada temática (no caso de canais de esporte, notícias etc.) como para um determinado público (jovens, crianças, mulheres etc.). Tendo em vista que a composição das imagens das televisões segmentadas costuma ser mais complexa e até mais caótica, a escolha por esse tipo de construção visual costuma facilitar o processo de leitura e reconhecimento por parte do telespectador.

Um canal aberto, por outro lado, precisa de uma estratégia diferente. A heterogeneidade do público o impulsiona a buscar formas abstratas, de caráter neutro, capazes de agradar - ou, pelo menos, não desagradar - a audiência como um todo (LIMA 1997, p. 72). De certo modo, isso funciona como uma "amarra figurativa", deixando as televisões abertas restritas ou limitadas quanto ao uso de figuras - em geral, formas básicas como o círculo, o quadrado, a linha e o ponto. De modo que seus vídeos institucionais costumam apresentar na tela menor variedade de elementos que os das televisões segmentadas. Todavia, é bom frisar que essas são considerações gerais, e não se aplicam às vinhetas de promoção de programas, justamente porque estes sempre têm um target mais ou menos específico e, consequentemente, podem ter maior ou menor direcionamento figurativo.

Ainda sobre a influência do perfil dos diferentes públicos sobre a programação e, especialmente, sobre o padrão estético das emissoras, o estudo de Cristina Lima revela que as vinhetas institucionais de emissoras segmentadas nos canais pagos possuem uma construção mais complexa, um ritmo mais dinâmico e estão em constante renovação. $\mathrm{O}$ telespectador é sempre surpreendido e instigado por um projeto gráfico novo, evitando que ele se canse ou atribua ao canal a pecha da "mesmice" ou da "mediocridade" e, por fim, o sancione negativamente. Pressupõe-se, portanto, que tal telespectador esteja devidamente modalizado, exibindo uma capacidade mais ágil e perspícua de leitura - o saber-fazer.

Esse aspecto esbarra, inevitavelmente, na questão do repertório e nos ajuda a entender - de outro prisma - por que as vinhetas institucionais dos canais pagos e segmentados costumam apresentar uma variedade maior de elementos que os vídeos das 
emissoras abertas e geralistas. Levando em consideração apenas a quantidade de canais e conteúdos ofertados, o fator financeiro, como um divisor de águas, coloca em lados opostos pessoas com mais e menos informação. E, razoavelmente, com mais e menos formação. Resultando em maior ou menor nível de exigência. É claro que a questão está aqui colocada de maneira demasiadamente simplista, porém, parece bastar o fato de que permite entrever a existência de aspectos sociais e educacionais que poderiam ser levados adiante se quiséssemos abordar em profundidade o fato de que as classes que consomem a televisão paga normalmente não fazem deste seu único e nem principal meio de informação ao passo que é comum isso acontecer com os que fruem a televisão aberta, sendo que pelo menos metade destes possuem déficits educacionais significativos.

Com vistas a esse público, as vinhetas da televisão aberta trabalham propositadamente com uma quantidade menor de elementos visuais a fim de fixá-los na mente do telespectador. Esse mínimo de informação permite que a assimilação dos produtos gráficos seja rápida e fácil para o grande público e a retenção fica por conta de redundâncias tanto no plano da expressão como no do conteúdo.

Outro aspecto que varia entre um tipo e outro de televisão é a quantidade de inserções de vinhetas durante o intervalo comercial. Visto que as emissoras pagas costumam apresentar uma quantidade menor de anunciantes, o tempo de espera entre um bloco e outro é preenchido com uma quantidade proporcionalmente maior de vídeos institucionais ou de promoção de programas. Daí o fato das vinhetas dos canais pagos serem mais dinâmicas, construídas com maior variedade de elementos e estarem em constante renovação. Essa tem sido a solução das televisões pagas para driblar o cansaço que a alta frequência de inserções pode causar no telespectador. E tais estratégias, à medida que se consolidam no tempo, terminam também por configurar uma estética própria para estes atuais objetos midiáticos de arte que, diferentemente dos de outrora, configuram-se pelo valor de exposição e não o de culto (BENJAMIM, 2000). De modo que o foco deixa de ser a reprodução de uma obra singular para dar lugar a obras feitas especialmente para serem reproduzidas - o que requer uma dinâmica específica de apresentação e uma nova estética também.

Apesar de esse novo valor - o de exposição - estar igualmente presente nas vinhetas da televisão aberta a lógica que as rege é absolutamente diferente. Isso acontece não apenas porque elas têm um índice comparativamente menor de inserções de vinhetas, mas pelo fato de que as produções que vão ar nesse caso não costumam rivalizar umas com as 
outras, nem sofrer quaisquer tipos de transformações, mantendo-se exatamente iguais e com total destaque durante o período em que são exibidas. Essa condição individual e absoluta, sem dúvida alguma, também responde pela escolha de uma menor quantidade de elementos e um padrão mais harmônico e limpo nas vinhetas da televisão aberta - o que parece tornar mais suportável seu caráter repetitivo no vídeo. E, tal como no caso anterior, o êxito dessa prática também tende a fazer da "mínima informação" uma estética para as vinhetas da televisão aberta.

\section{Tipos, usos e funções}

\section{Sobre tipos}

Desde o aparecimento da televisão, vimos que as vinhetas se dividem em apenas dois tipos básicos: as que promovem marcas e as que promovem produtos. Assim, ou carregam o nome e símbolo da emissora ou então dos programas da grade.

É esse caráter comercial o responsável pelo agrupamento de tantas produções diferentes sob a nomenclatura vinheta. É o traço em comum entre diferentes tipos e formas de vinhetas televisivas, independentemente de época, lugar, modos de produção, representação e apresentação. Qual a diferença, então, entre uma vinheta e um comercial regular? Apenas o objeto da ação publicitária, que no caso da vinheta se volta para a própria televisão. E essa característica definidora, como se verá nos próximos parágrafos, também exerce uma forte influência sobre as formas de uso e funções da vinheta televisiva.

Sobre usos e funções

Em todos os sistemas de radiodifusão desenvolvidos a organização característica e, por conseguinte, a experiência característica, é a sequencialidade ou fluxo. Esse fenômeno, do fluxo planejado, é certamente a característica definidora da radiodifusão (WILLIAMS, 1990, p. 79$)^{49}$.

\footnotetext{
${ }^{49}$ Tradução livre. No original: "In all developed broadcasting systems the characteristic organisation, and therefore the characteristic experience, is one of sequence or flow, is then perhaps the defining characteristic of broadcasting" (WILLIAMS, 1990, p. 79).
} 
De acordo com Raymond Williams, nos sistemas broadcasting tanto o modo de organização interno como a própria experiência do sujeito que frui esse tipo de mídia são marcados pelo que o autor definiu como sequencialidade ou fluxo. A ideia que quero destacar a partir desses termos é a impressionante capacidade que os meios massivos têm em apresentar uma vasta gama de conteúdos, uma após o outro, continuamente, sem que nenhum deles tenha a obrigação de se comunicar ou se relacionar com a atração anterior ou posterior.

O fluxo televisivo, no entanto, não é tão caótico quanto pode parecer, pois a produção em série para o grande público foi estabelecendo, tanto dentro como fora dos programas, certas estratégias de otimização não só do tempo - que se apresenta, talvez, como o aspecto coercivo mais evidente - mas também em relação à disposição espacial dos conteúdos.

Por exemplo, é sabido que os intervalos da programação são hoje comercializados tendo-se em mente o tempo de exibição ou permanência de determinado produto no ar. A venda é feita a partir de múltiplos de 15 segundos, sendo 30 s o padrão. Porém, algumas empresas estão dispostas a pagar um pouco mais para que possam determinar onde serão feitas as inserções de seus produtos, como, por exemplo, logo no início do intervalo. Essa escolha, como se pode deduzir, não é aleatória. Antes, evidencia que determinados espaços do break possuem mais valor que outros - neste caso, em razão de uma maior ou menor visibilidade real.

A própria disposição da grade vertical da programação também é pensada com vistas à colocação de conteúdos no lugar certo para eles. Isso acontece com a inserção de programas destinados a públicos específicos como crianças e donas de casa em horários estrategicamente pré-determinados e, sobretudo, com o encadeamento de atrações que possam forçar a permanência do público em frente ao televisor.

Enfim, a televisão está cheia de casos como esses - que demonstram bem como a dinâmica do fluxo ou sequencialidade dos conteúdos constitui-se uma prática televisiva totalizante, composta por alguns percursos estáveis de produção. Tal afirmação decorre do fato de que a grade televisiva é hoje um todo interdependente. E o caráter sequencial dos conteúdos, tanto no decorrer do dia como da semana, é o principal agente na definição de uma estrutura vertical e horizontal. Em termos semióticos, tal disposição espacial e temporal dos programas corresponde, dentro do percurso gerativo do sentido do plano da expressão proposto por Jacques Fontanille (2008), ao nível das cenas predicativas, 
conforme o quadro mais a frente. Os percursos estáveis de produção, por sua vez, nada mais são que estratégias bem-sucedidas e, por isso, repetidas exaustivamente na TV. Levam em conta - ou têm como tipo de experiência - a conjuntura e, por essa razão, submetem-se a diversos tipos de programações e ajustamentos (FONTANILLE, 2008; LANDOWSKI, 2003).

Quadro 2: Percurso gerativo do plano da expressão

\begin{tabular}{|c|c|c|}
\hline Tipo de Experiência & Instâncias Formais & Instâncias Materiais \\
\hline (1) Figuratividade & Figuras-Signo & $\begin{array}{l}\text { Propriedades sensíveis e materiais } \\
\text { das figuras }\end{array}$ \\
\hline (2) Interpretação & Textos-Enunciados & $\begin{array}{l}\text { Propriedades sensíveis e materiais } \\
\text { dos textos }\end{array}$ \\
\hline (3) Corporeidade & Objetos & $\begin{array}{l}\text { Propriedades sensíveis e materiais } \\
\text { dos objetos }\end{array}$ \\
\hline (4) Prática & Cenas Predicativas & $\begin{array}{l}\text { Propriedades sensíveis e materiais } \\
\text { das cenas }\end{array}$ \\
\hline (5) Conjuntura & Estratégia & $\begin{array}{c}\text { Propriedades sensíveis e materiais } \\
\text { das estratégias }\end{array}$ \\
\hline (6) Ethos e comportamento & Formas de Vida & $\begin{array}{c}\text { Propriedades sensíveis e materiais } \\
\text { das formas de vida }\end{array}$ \\
\hline
\end{tabular}

(FONTANILLE in PORTELA; DINIZ, 2008, p. 18)

Para aclarar um pouco mais: quando falo em prática estou me referindo a um modo habitual de agir, um uso estabelecido, um certo modo de fazer as coisas que se deixa reger por uma estratégia ou arte de dirigir um conjunto de disposições. Neste caso, abordo o nível de pertinência das práticas não de maneira totalmente isolada - embora esse tipo de análise seja possível - mas tomando em consideração certas relações que ele estabelece com o nível de pertinência ascendente (em direção à cultura).

Sendo assim, o que é prática e o que é estratégia?

De acordo com Fontanille, "uma prática é constituída em sua superfície por um conjunto de atos, cuja significação raramente é conhecida de antemão, e que se constrói 'em tempo real' por adaptações desses atos em relação uns aos outros" (in PORTELA, 2008, p. 181). Visto que as adaptações ou ajustamentos estão previstos e, de fato, interpelam muitas vezes a programação prévia da prática, cabe à ação estratégica - tomada aqui como sinônimo de planejamento eficiente - fornecer a solução mais adequada. Em alguns casos, o êxito alcançado é tão formidável que a ação estratégica pode vir a constituir-se uma nova prática, substituindo a anterior. 
Estratégia
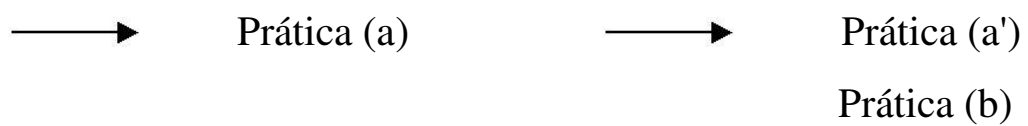

Essa nova prática pode tanto guardar semelhanças com a prática realizada anteriormente, como mostrar-se radicalmente nova. Assim, o esquema esboçado mostra que a ação estratégica pode incidir com variados graus de intervenção sobre uma determinada prática, conduzindo tanto a um ajustamento mais brando, capaz de lhe preservar os traços distintivos - transformando uma "prática (a)" em "prática (a')" - como mais intenso, capaz de mexer com seus elementos característicos, imprimindo-lhes uma configuração totalmente diferente - transformando uma "prática (a)" em "prática (b)".

Esses dois tipos de ajustamentos são comuns na televisão. Isso se dá, especialmente, pelo fato de que o fluxo ou sequencialidade dos conteúdos se apresenta como uma enunciação em ato - em razão do "tempo real" de sua veiculação e, em alguns casos, da própria produção "ao vivo" de alguns dos conteúdos que o integram. Outro fator pode ser a própria resposta da audiência, em decorrência de sua não-aceitação ou desestímulo para com a programação. Mas, se tomarmos um viés histórico - tendo em consideração, por exemplo, o desenvolvimento tecnológico e de linguagem da TV veremos que algumas das fórmulas que hoje sustem certas práticas (tanto no interior dos programas como também fora deles) resultam não de um ajustamento único e de caráter definitivo, mas de um ajustamento progressivo, quer dizer, da aplicação repetida do esquema anterior - ao longo de tempo - sobre um determinado objeto:

1) Estratégia

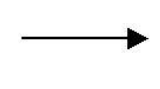

2) Estratégia

3) Estratégia

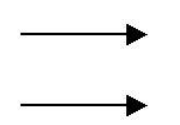

Prática (a)

Prática (a')

Prática (c)

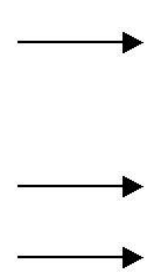

Prática (a')

Prática (b)

Prática (c)

Prática (d) 
Essa dinâmica é claramente observável na retrospectiva que levantei no decorrer deste apêndice. No que diz respeito às vinhetas, as práticas foram não só continuamente aprimoradas em termos técnicos e também de execução, como tais mudanças estratégicas permitiram ao objeto sair de um estado de indefinição - lembrando que não havia inicialmente uma divisão muito precisa, por exemplo, entre vinhetas institucionais e vinhetas de promoção de programas - e entrar em outro no qual a nomenclatura que carregam está condicionada à realização de funções bem específicas. Assim, voltando-nos para o quadro atual das aparições estratégicas das vinhetas, como estão sendo elas utilizadas na TV?

Começarei pelas inserções mais amplamente conhecidas. Considerando que existem apenas dois tipos básicos de vinhetas - as que promovem a marca da emissora e as que promovem os produtos televisivos -, algumas vinhetas de promoção de programas têm suas funções definidas a partir do espaço que ocupam no fluxo, tendo em vista a anterioridade ou posterioridade de sua aparição em relação a certos conteúdos ou bloco de conteúdos. Isso acontece, por exemplo, com as vinhetas de abertura, passagem e encerramento. Como o próprio nome indica, são funções que somente podem ser alcançadas, respectivamente, pelo posicionamento da vinheta imediatamente antes do início da atração; na saída para os intervalos e no retorno ao programa; e ao término de um conteúdo específico. Qualquer inserção diferente disso seria o bastante para descaracterizar tais propostas - ou mesmo configurar uma outra.

É o caso das vinhetas de chamada para as próximas atrações e até das vinhetas institucionais. Em relação ao espaço que ocupam no break, sua principal característica atual é uma certa aleatoriedade. E justamente por não terem sua aparição vinculada espacialmente a outro conteúdo - quer por anterioridade quer por posterioridade - ganham uma nomenclatura e uma função diversas das demais. Diferentemente das que vimos até agora, elas não têm, de modo geral, a necessidade de aparecer antes ou depois de determinados eventos. Precisam, apenas, aparecer. Estão, portanto, mais livres no fluxo e podem, por isso mesmo, serem utilizadas até como elemento de controle dele - sendo inseridas com mais frequência quando há espaços vazios e com menos frequência quando estes já estão devidamente ocupados com os anúncios comerciais de outras empresas.

Evidentemente, a forma de apresentação das vinhetas de abertura, passagem, encerramento e também das que fazem chamadas para as próximas atrações não são as mesmas ainda que tratem de um mesmo objeto ou programa da grade. Isso ocorre porque 
ao determinar certas funções, o modo de inserção ou espaço que tais produções ocupam no fluxo determina também modos de produção específicos - em muitos casos alcançados, dilapidados e mesmo validados pela repetição (tentativa e erro) no decorrer do tempo, até estabelecer modelos canônicos.

É assim, pois, que vinhetas de abertura tendem a ser mais descritivas ou mesmo meta-narrativas quando acompanham conteúdos ficcionais, e mais focadas na efetivação de contratos quando o caráter dos programas é não-ficcional; que vinhetas de passagem e encerramento costumem ser uma exibição parcial ou resumida da vinheta que realiza a abertura do programa em questão; e que vinhetas de chamada de programas apresentem breves excertos dos conteúdos que anunciam. É claro que estes são apenas alguns exemplos e não há aqui qualquer pretensão de exaustividade. Mesmo porque seria impossível impor limites à criatividade humana.

\section{Minimizar ou maximizar a tensão}

Nesse sentido, há uma prática muito curiosa da televisão brasileira envolvendo o uso de vinhetas. Trata-se da fórmula R2P-P2R ${ }^{50}$. Este é, na verdade, um sintagma composto por um programa (P), uma vinheta de passagem (2), e uma vinheta de chamada de um conteúdo qualquer da grade $(\mathrm{R})$. Na tabela a seguir, fica fácil enxergar a grande quantidade de vezes que tal fórmula aparece nos intervalos comerciais das principais emissoras abertas do país, independentemente do programa em andamento.

\footnotetext{
${ }^{50}$ Mantive a nomenclatura utilizada - e justificada - em publicações ulteriores: SCHIAVONI, 2008; 2011.
} 
Quadro 3 - A autorreferencialidade na televisão

\begin{tabular}{|c|c|c|}
\hline \multicolumn{3}{|c|}{ Rede Globo de Televisão } \\
\hline $\begin{array}{c}\text { Telejornal } \\
\text { P2R } \bullet \bullet \bullet \bullet \bullet \bullet R 2 P\end{array}$ & 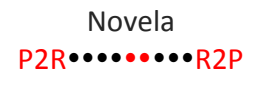 & 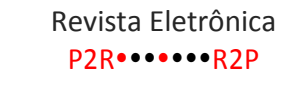 \\
\hline \multicolumn{3}{|c|}{ Rede Bandeirantes de Televisão } \\
\hline 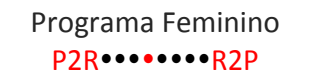 & $\begin{array}{l}\text { Programa Esportivo } \\
\text { P2R } \bullet \cdots \bullet \bullet \bullet \bullet \bullet \cdot R 2 P\end{array}$ & $\begin{array}{c}\text { Telejornal } \\
\text { P2R・・••・R2P }\end{array}$ \\
\hline \multicolumn{3}{|c|}{ Sistema Brasileiro de Televisão } \\
\hline $\begin{array}{l}\text { Programa de Entrevista } \\
\qquad \text { P2 } \bullet \bullet \bullet \bullet \bullet \bullet R 2 P\end{array}$ & $\begin{array}{c}\text { Telejornal } \\
\text { P2R } \bullet \bullet \bullet \bullet 2 P\end{array}$ & $\begin{array}{l}\text { Programa Musical } \\
\text { P2R } \bullet \bullet \bullet \bullet \bullet \bullet \bullet 2 P\end{array}$ \\
\hline \multicolumn{3}{|c|}{ Rede Record de Televisão } \\
\hline $\begin{array}{c}\text { Telejornal } \\
\text { P2 } \bullet \bullet \bullet \bullet \bullet \bullet \bullet R 2 P\end{array}$ & $\begin{array}{c}\text { Novela } \\
\text { P2R } \bullet \bullet \bullet \bullet \bullet \bullet \cdot 2 P\end{array}$ & $\begin{array}{l}\text { Reality Show } \\
\text { P2R } \bullet \bullet \bullet \bullet 2 P\end{array}$ \\
\hline \multicolumn{3}{|c|}{ TV Cultura } \\
\hline $\begin{array}{c}\text { Telejornal } \\
\text { P2R・••••••R2P }\end{array}$ & $\begin{array}{l}\text { Revista Eletrôniica } \\
\text { P2R } \bullet \bullet \bullet \bullet \bullet \bullet R 2 P\end{array}$ & $\begin{array}{c}\text { Programa de Entrevista } \\
\text { P2R } \cdots \bullet \bullet \cdot R 2 P\end{array}$ \\
\hline
\end{tabular}

Cada bloco da tabela corresponde a um bloco comercial. Os pontos pretos correspondem aos anúncios independentes e os pontos vermelhos aos anúncios da própria emissora, como detalharei mais adiante. Quanto ao uso da fórmula, suas partes iniciais e finais encontram-se sempre no começo e término dos intervalos. Dada a frequência dessas aparições, qual o seu sentido na televisão?

Bem, como se sabe, o fluxo televisivo é marcado por continuidades e descontinuidades, por programas e intervalos. Numa acepção semiótica, isso equivaleria dizer que o fluxo televisivo - apesar de sua progressão - é mantido por contrastes entre um fazer emissivo e um fazer remissivo. Ou seja, um jogo de valores em torno de alguma coisa que "acontece" ou "deixa de acontecer".

Enquanto o fazer remissivo estabelece o que Claude Zilberberg (2006) define como "parada", o fazer emissivo desenvolve a "parada da parada". E não apenas isso. Tais valores - remissivo e emissivo - têm o poder de incidir tanto sobre o estado tímico do sujeito - neste caso, o telespectador - como sobre o modo como se configuram e são percebidos o tempo e o espaço da televisão, cujo fluxo tomarei como um texto, no sentido semiótico do termo.

Assim, de acordo com a teoria, o fazer remissivo, portador da "parada", é definido por uma cronopoiese no que diz respeito ao tempo e por um fechamento no que se refere ao espaço. O fazer emissivo, portador da "parada da parada", pelo contrário, é definido por cronotrofia em relação ao tempo e uma abertura quanto ao espaço. O que isso significa? 


\begin{tabular}{|c|c|c|c|}
\hline \multicolumn{2}{|c}{} & \multicolumn{3}{|c|}{ Quadro 4 - Fazer missivo } \\
\hline MISSIVIDADE & CARACTERÍSTICA & TEMPO & ESPAÇO \\
\hline Fazer remissivo & "parada" & Cronopoiese & Fechamento \\
\hline Fazer emissivo & "parada da parada" & Cronotrofia & Abertura \\
\hline
\end{tabular}

O termo cronopoiese é formado por poiêsis, do grego, que indica criação ou capacidade de produzir ou fazer alguma coisa. Em relação ao fazer remissivo, pode-se dizer que a "parada" cria o tempo da espera ou uma temporalidade expectante. Se, por assim dizer, o tempo sofre uma dilação, o efeito da remissividade sobre o espaço é o de fechamento, mantendo-o circunscrito.

O termo cronotrofia, por sua vez, provém de trophê, também do grego, que significa alimentar, no sentido de desenvolver-se. Assim, o fazer emissivo, com a "parada da parada", consome o tempo, transformando-o num "tempo que passa". Seu efeito sobre o espaço é o de abertura, tornando-o difuso, de maneira que o fluxo pode nele se desenvolver.

Conforme explica Zilberberg, "quando o tempo emissivo está em operação, ou seja, é dominante, segue seu curso, o retorno do remissivo é vivido como surpresa, desordem e, evidentemente, como interrupção" (2006, p. 136). Por isso, a utilização da fórmula "P2R" no início do intervalo tende a diminuir esse sentido para o sujeito, tornando menos brusca a entrada de comerciais.

Por outro lado, quando o fazer remissivo é que domina - "em suma enquanto continuar a parada... - o tempo emissivo irá manter-se suspenso e inibido, e esse tempo remissivo aparece[rá] realmente, tendo em vista o tempo emissivo, como um tempo antes do tempo!" (Idem, p. 135). Ou seja, como um tempo de espera, de expectativa pelo retorno do tempo emissivo. Desse modo, a aparição da segunda parte da fórmula ao final do intervalo, constituída pela sequência "R2P", tem por objetivo fazer diminuir a tensão da espera na medida em que garante ao telespectador um "sinal de aviso" de retorno da atração, quando esta for reiniciar seu curso, permitindo ao sujeito certo relaxamento e distração até que isso ocorra.

Para essa hipótese, corrobora o fato de que esse "sinal de aviso" é sempre acompanhado por uma alteração (para mais) no volume da transmissão. E, em alguns casos, até por uma mudança de ritmo dos reclames. Isso acontece, especialmente, no caso 
em que a letra "R" da fórmula se constitui por comerciais de apoio à programação. Tais produções constituem um tipo híbrido, pois ao mesmo tempo em que destacam um serviço, produto ou marca independente, sua aparição surge atrelada à programação televisiva por aspectos sonoros e visuais. Em decorrência disso, encaixam-se como conteúdos que fazem referência à grade de programação. Em geral, esse tipo de reclame costuma aglutinar a apresentação de diversos apoiadores, de modo que o tempo destinado a cada um deles se torna menor que as inserções comerciais regulares. Tal caráter mais curto e rápido, tanto em termos visuais como sonoros, imprime um ritmo diferente ao break e sua aparição imediatamente antes da vinheta de passagem termina por reforçar o "sinal de aviso" de retorno ao programa.

De maneira que a fórmula - "R2P" - altera as características do tempo da espera, transformando-o num momento de recondicionamento em vez de tensão - o que se dá, sobretudo, porque tal dinâmica libera espacialmente o sujeito, que não precisa mais estar diante do aparelho televisivo, podendo movimentar-se e realizar atividades diversas que contribuirão para um sentido acelerado da passagem do tempo remissivo, relativizando a expectativa.

Tal estratégia é levada ao ar repetidas vezes todos os dias, constituindo uma verdadeira prática semiótica, e pode fazer com que até aquele telespectador que ainda não decifrou ou identificou cognitivamente a fórmula consiga pressentir pelo hábito, pela dimensão sensível, que o intervalo terminará em breve e possa, assim, fazer seus últimos ajustes a fim de voltar ao ecrã sem perder parte da atração que está acompanhando.

É digno de nota, porém, que tal fórmula - "P2R-R2P" - seja não só característica, mas também exclusiva das televisões abertas. Nos canais fechados, visto que os intervalos são quase inteiramente - ou mesmo totalmente - tomados por vinhetas institucionais e de promoção de produtos da grade, ela simplesmente se dissolve. Daí certa sensação de "falta de controle" por parte do telespectador e um sentido sempre renovado de tensão por não conseguir mensurar o tempo de duração dos intervalos - que se mostra bastante variável, às vezes mais longo, às vezes mais curto - e também por não poder contar com qualquer recurso sistematizado de aviso sobre o retorno à programação.

O telespectador se sujeita, nesses casos, a manter um sentido constante de alerta, que ao final de certo tempo pode vir a deixá-lo exausto. Se considerarmos que os intervalos existem a fim de fornecer um momento de relaxamento, descontração e recondicionamento - até mesmo em vista do próprio contexto doméstico e disperso de uso da televisão - é 
como se essa "parada" do fluxo não tivesse existido de fato ou não tivesse alcançado plenamente seu propósito, apesar da interrupção real no curso das atrações. É por isso que alguns conseguem passar o dia em frente a televisão aberta, mas não conseguem suportar muitas horas em frente a televisão fechada.

Creio que se trate, tanto num caso como no outro, de uma escolha estratégica. Visto que as televisões abertas precisam da audiência e possuem uma grade estável e bem conhecida pelo público, com conteúdos inéditos em praticamente todos os horários, pode, por assim dizer, dispensar o telespectador nos períodos de intervalo, permitindo seu recondicionamento para que permaneça o tempo todo ligado. Já nas televisões fechadas a situação é diametralmente oposta. Uma vez assinada a conta, é mais fundamental para elas atrelar sua marca aos conteúdos fortes que vendem o canal do que, propriamente, a permanência do telespectador em frente à tela. E como a grade nestes casos não é tão estável e alguns conteúdos chegam a se repetir até mesmo de maneira sequencial, a emissora sabe que o telespectador não ficará por muito tempo. Por isso, não investe em estratégias de "longo prazo" como a fórmula "P2R-R2P", que minimiza a tensão e permite o recondicionamento do sujeito, mas em outras de tipo "imediato", que buscam segurar o telespectador o máximo possível durante um período limitado - o da execução do programa em curso, incluindo os espaços comerciais - para promover de maneira efetiva a marca da emissora a partir de sua carta de conteúdos, bombardeando o sujeito com vinhetas institucionais e de programas. Assim, as televisões fechadas não dispensam o telespectador durante os intervalos, mas mantêm a tensão para chamar a atenção.

Dentro dos programas, o papel das vinhetas em relação ao fluxo televisivo também é importante. Estrategicamente posicionadas, elas são responsáveis por fazer a separação entre as diferentes seções apresentadas. São elas, portanto, que marcam a organização dos assuntos abordados e, novamente, o fluir do tempo. Dado o atual ritmo acelerado de alguns programas, tais como as revistas eletrônicas e certos telejornais, correríamos o risco de não perceber onde terminou um assunto e começou outro se não fosse essa função "cortina" desempenhada pelas vinhetas.

\section{Estética da autorreferencialidade}

Voltando à tabela, não por acaso ela foi construída a partir de cores diferentes. Os pontos pretos referenciam a presença de anúncios que em nada têm a ver com a rede de televisão que os transmitem. Alguns deles têm veiculação nacional, outros são de âmbito 
local, mas para o aspecto que desejo focar a distinção entre essas categorias não é importante. Tão pouco é relevante o tipo de produto anunciado. Não importa se se trata de material de higiene, venda de veículos, brinquedos, roupas ou alimento. O que vale é que as marcas, produtos e os serviços anunciados não possuem qualquer ligação com a emissora. A esse tipo de inserção publicitária chamarei de comercial independente.

Como as redes de televisão aberta são sustentadas em maior ou menor grau pelos anunciantes, a primeira coisa que vem à mente é que são esses comerciais os que mais aparecem nos intervalos. Mas não é assim. A quantidade de vezes que figuram no break corresponde quase sempre a menos da metade das inserções totais ${ }^{51}$. Na TV Cultura, em que essa dinâmica é mais evidente, eles ocupam apenas $18 \%$ do intervalo. Na Band são 40\%; na Globo, 42\%; no SBT, $53 \%$ e, na Record, $61 \%$.

O restante do intervalo é todo preenchido com conteúdos que levam a marca da emissora ou das atrações da grade televisiva. Esses são representados na tabela por pontos vermelhos. Diferentemente dos casos anteriores, em todos estes há uma relação de dependência entre os serviços, produtos ou marcas anunciadas e a própria emissora. Tais anúncios podem compreender produtos da empresa ou grupo responsável pela rede de televisão; comerciais financiados pela emissora ou por afiliadas (como mensagens de datas comemorativas ou companhas de cidadania e saúde); produções com a logomarca da emissora, etc. Em todos os casos, por levarem a assinatura do canal, constituem-se vinhetas institucionais. E há também as vinhetas de chamada de programas, que indicam o horário e o conteúdo das atrações: avisam sobre a trama da novela, os destaques do esporte, as notícias do jornal e assim por diante. A todos esses denomino comerciais autorreferenciais, por fazerem referência direta ou indireta à marca da emissora e de seus produtos ou serviços.

A alta porcentagem desse tipo de inserção publicitária configura para a televisão o que se chama de estética da autorreferencialidade - e pode ser observada na tabela anterior pela grande quantidade de inserções de pontos vermelhos nela, além da própria fórmula "P2R-R2P”. Na Rede Globo, emissora a qual me dedico neste trabalho, esse índice de aparição chega a 58\%. Tal margem pode até parecer excessiva à primeira vista, mas é o que garante até hoje boa parte da audiência. Afinal, "quem não anuncia, não vende". E não se trata apenas de informar o telespectador sobre a programação na tentativa de segurá-lo

\footnotetext{
${ }^{51}$ A tabela anterior apresenta, a título de exemplo, apenas um dos blocos comerciais que acompanham cada programa. Os dados aqui fornecidos levam em conta todos os demais.
} 
por mais tempo diante da tela. É, sobretudo, pela repetição que as marcas ficam guardadas em nossa mente, como esbocei no tópico anterior ao tratar da atuação das televisões fechadas.

Isso explica todo o trabalho de planejamento e produção em torno das vinhetas que aparecem nos intervalos comerciais - tanto no sentido de modalizar o sujeito do outro lado da tela para o "querer-ver", no caso das vinhetas de promoção de programas, como também no caso de sensibilizá-lo para os valores eufóricos associados à marca da emissora, amplamente disseminados nas vinhetas institucionais, e com os quais ele poderá entrar em conjunção ao decidir-se por aquele determinado canal.

\section{Evento estético}

Tanto nos intervalos comerciais como no decorrer dos programas, a aparição das vinhetas pode ir além das funções que apresentei até aqui e chegar a estabelecer o que se chama de evento estético. Conforme explica Oliveira,

o evento estético é sempre arrebatador e a cognição que ele processa realiza-se 'pela' e 'na' quebra de relação com o estado precedente no qual o sujeito se situava. Por retirá-lo bruscamente de um estado e provocar um sentir a transformação em curso, essa narratividade instaura um outro ritmo no percurso do sujeito. $\mathrm{Na}$ descontinuidade, sem competência prévia para processar a cognição do que lhe invade, o sujeito experimenta uma intensificação dos seus sentidos, que expande as suas potencialidades por meio de articulações entre os registros sensíveis (OLIVEIRA, 2003, p. 3).

Assim, vemos que a particularidade do evento estético é propiciar uma fratura na isotopia da cotidianidade, que se constituiu pelas pequenas e medíocres preocupações que ocupam nossos pensamentos e ações no decorrer do dia-a-dia. Enquanto a "grande arte" desencadeia o extraordinário como uma ruptura do fluxo contínuo da vida, promovendo ressemantizações tanto do mundo vivido como do próprio sujeito que o percebe, a vinheta pode, em alguns casos, promover uma ruptura do fluxo da televisão, provocando, a partir da convocação sensória, estésica, um recondicionamento e até mesmo um apagamento das referências do sujeito, deslocando-o do tempo e do espaço em que se situa. 
Para exemplificar esse tipo de função bataria pensar em vinhetas como as do "Plantão da Globo". Elas aparecem de modo esporádico e também muito criterioso na TV. Interrompendo qualquer conteúdo em exibição, ou seja, provocando uma quebra no fluxo previsto, carregam um sentido de urgência muito forte. A velocidade do movimento das imagens dessa vinheta somado a uma sonoridade de grande intensidade e ritmo igualmente acelerado constituem-se um verdadeiro chamado de alerta. Quando são disparadas no ar, conseguem alcançar um momento de paralisação das atividades do público que chega a ser impressionante. É, sem dúvida, um momento de suspensão. Um evento estético. 


\section{Apêndice II}

\section{Rede Globo: \\ Slogans e identidade}

\begin{tabular}{|c|c|c|c|c|}
\hline \multicolumn{5}{|c|}{ "Hoje é juventude, 10 anos e aí estamos nós, caminhando com você" } \\
\hline $\begin{array}{c}\text { Enunc. Fundamental } \\
\text { Mediação }\end{array}$ & $\begin{array}{l}\text { Promessa } \\
\text { Interação }\end{array}$ & $\begin{array}{c}\text { Especif. Promessa } \\
\text { Global }\end{array}$ & $\begin{array}{l}\text { Território } \\
\text { Televisão }\end{array}$ & $\begin{array}{c}\text { Valores } \\
\text { Tecnologia/Pluralidade }\end{array}$ \\
\hline & $\begin{array}{l}\text { "caminhando com você" = } \\
\text { atividade realizada } \\
\text { conjuntamente; } \\
\text { interação } \\
\text { não-mediada }\end{array}$ & & "nós" = emissora & \\
\hline \multicolumn{5}{|c|}{ "Agora mais um campeão de audiência" / "Vem aí mais um campeão de audiência" } \\
\hline $\begin{array}{c}\text { Enunc. Fundamental } \\
\text { Mediação }\end{array}$ & $\begin{array}{l}\text { Promessa } \\
\text { Interação }\end{array}$ & $\begin{array}{c}\text { Especif. Promessa } \\
\text { Global }\end{array}$ & $\begin{array}{l}\text { Território } \\
\text { Televisão }\end{array}$ & $\begin{array}{c}\text { Valores } \\
\text { Tecnologia/Pluralidade }\end{array}$ \\
\hline $\begin{array}{l}\text { "audiência" = } \\
\text { pressupõe conteúdos } \\
\text { transmitidos por um } \\
\text { meio de comunicação }\end{array}$ & $\begin{array}{l}\text { "audiência" = assistir } \\
\text { televisão; pressupõe a } \\
\text { participação do público }\end{array}$ & & $\begin{array}{l}\text { "audiência"= } \\
\text { termo próprio de } \\
\text { meios massivos }\end{array}$ & $\begin{array}{l}\text { "campeão de } \\
\text { audiência" = } \\
\text { muitas pessoas; } \\
\text { pluralidade }\end{array}$ \\
\hline \multicolumn{5}{|c|}{ "Essa gente que você não vê, faz a televisão que você vê" } \\
\hline $\begin{array}{c}\text { Enunc. Fundamental } \\
\text { Mediação }\end{array}$ & $\begin{array}{l}\text { Promessa } \\
\text { Interação }\end{array}$ & $\begin{array}{c}\text { Especif. Promessa } \\
\text { Global }\end{array}$ & $\begin{array}{l}\text { Território } \\
\text { Televisão }\end{array}$ & $\begin{array}{c}\text { Valores } \\
\text { Tecnologia/Pluralidade }\end{array}$ \\
\hline $\begin{array}{l}\text { "faz a televisão" } \\
\text { = mediação; } \\
\text { valorização a instância } \\
\text { da enunciação }\end{array}$ & $\begin{array}{l}\text { "você vê"= } \\
\text { pressupõe a participação } \\
\text { do público }\end{array}$ & & "televisão" & \\
\hline
\end{tabular}

\begin{tabular}{|c|c|c|c|c|}
\hline $\begin{array}{c}\text { Enunc. Fundamental } \\
\text { Mediação }\end{array}$ & $\begin{array}{l}\text { Promessa } \\
\text { Interação }\end{array}$ & $\begin{array}{c}\text { Especif. Promessa } \\
\text { Global }\end{array}$ & $\begin{array}{l}\text { Território } \\
\text { Televisão }\end{array}$ & $\begin{array}{c}\text { Valores } \\
\text { Tecnologia/Pluralidade }\end{array}$ \\
\hline $\begin{array}{l}\text { "no ar" = } \\
\text { Conteúdos } \\
\text { mediatizados } \\
\text { "pique" = } \\
\text { Intensa e animada } \\
\text { atividade de trabalho }\end{array}$ & $\begin{array}{l}\text { "entre no ar" = convida o } \\
\text { público a participar }\end{array}$ & & $\begin{array}{l}\text { "no ar" = } \\
\text { expressão de meios } \\
\text { como a televisão; } \\
\text { "Globo" = } \\
\text { nome da emissora }\end{array}$ & $\begin{array}{l}\text { "no ar" = } \\
\text { tecnologia de } \\
\text { transmissão de sinal }\end{array}$ \\
\hline
\end{tabular}


"O que pinta de novo, pinta na tela da Globo"

\begin{tabular}{|c|c|c|c|c|}
\hline $\begin{array}{l}\text { Enunc. Fundamental } \\
\text { Mediação }\end{array}$ & $\begin{array}{l}\text { Promessa } \\
\text { Interação }\end{array}$ & $\begin{array}{c}\text { Especif. Promessa } \\
\text { Global }\end{array}$ & $\begin{array}{l}\text { Território } \\
\text { Televisão }\end{array}$ & $\begin{array}{c}\text { Valores } \\
\text { Tecnologia/Pluralidade }\end{array}$ \\
\hline $\begin{array}{l}\text { "pinta de novo, pinta } \\
\text { na tela" = } \\
\text { o que acontece é } \\
\text { mediatizado }\end{array}$ & & $\begin{array}{l}\text { "o que pinta de novo" } \\
=\text { em qualquer lugar, } \\
\text { sem restrições }\end{array}$ & $\begin{array}{l}\text { "tela" = ecrã televisivo } \\
\text { "Globo" = referência } \\
\text { ao nome da emissora }\end{array}$ & $\begin{array}{l}\text { "o que pinta de novo" } \\
\text { = qualquer conteúdo, } \\
\text { sem restrições; } \\
\text { pluralidade de } \\
\text { conteúdos para } \\
\text { contemplar } \\
\text { pluralidade do público }\end{array}$ \\
\hline \multicolumn{5}{|c|}{ "O veículo de comunicação número 1 do país" } \\
\hline $\begin{array}{l}\text { Enunc. Fundamental } \\
\text { Mediação }\end{array}$ & $\begin{array}{l}\text { Promessa } \\
\text { Interação }\end{array}$ & $\begin{array}{c}\text { Especif. Promessa } \\
\text { Global }\end{array}$ & $\begin{array}{l}\text { Território } \\
\text { Televisão }\end{array}$ & $\begin{array}{c}\text { Valores } \\
\text { Tecnologia/Pluralidade }\end{array}$ \\
\hline $\begin{array}{l}\text { "veículo de } \\
\text { comunicação" = } \\
\text { mediação }\end{array}$ & $\begin{array}{l}\text { “comunicação" = } \\
\text { Fazer-enunciativo } \\
\text { pressupõe um } \\
\text { Fazer-interpretativo }\end{array}$ & & $\begin{array}{l}\text { "veículo" = } \\
\text { termo midiático, } \\
\text { utilizado também para } \\
\text { a televisão }\end{array}$ & \\
\hline
\end{tabular}

\begin{tabular}{|c|c|c|c|c|}
\hline \multicolumn{5}{|c|}{ "Vem que tem, na Globo tem" } \\
\hline $\begin{array}{l}\text { Enunc. Fundamental } \\
\text { Mediação }\end{array}$ & $\begin{array}{l}\text { Promessa } \\
\text { Interação }\end{array}$ & $\begin{array}{c}\text { Especif. Promessa } \\
\text { Global }\end{array}$ & $\begin{array}{l}\text { Território } \\
\text { Televisão }\end{array}$ & $\begin{array}{c}\text { Valores } \\
\text { Tecnologia/Pluralidade }\end{array}$ \\
\hline & $\begin{array}{l}\text { "vem" = } \\
\text { convite feito ao público } \\
\text { para participar }\end{array}$ & & $\begin{array}{l}\text { "Globo" = } \\
\text { nome da emissora }\end{array}$ & $\begin{array}{l}\text { "na Globo tem" = } \\
\text { pluralidade de } \\
\text { conteúdos }\end{array}$ \\
\hline
\end{tabular}

\begin{tabular}{|c|c|c|c|c|}
\hline \multicolumn{5}{|c|}{ "Pega essa onda, essa onda pega" } \\
\hline $\begin{array}{l}\text { Enunc. Fundamental } \\
\text { Mediação }\end{array}$ & $\begin{array}{l}\text { Promessa } \\
\text { Interação }\end{array}$ & $\begin{array}{c}\text { Especif. Promessa } \\
\text { Global }\end{array}$ & $\begin{array}{l}\text { Território } \\
\text { Televisão }\end{array}$ & $\begin{array}{c}\text { Valores } \\
\text { Tecnologia/Pluralidade }\end{array}$ \\
\hline & $\begin{array}{l}\text { "pega essa onda" = convite } \\
\text { feito ao público para } \\
\text { participar }\end{array}$ & & $\begin{array}{l}\text { "onda" = } \\
\text { tecnologia utilizada } \\
\text { também pela televisão }\end{array}$ & $\begin{array}{l}\text { "onda" = } \\
\text { tecnologia de } \\
\text { transmissão de sinal } \\
\text { "essa onda pega" = } \\
\text { qualidade do sinal }\end{array}$ \\
\hline
\end{tabular}

\begin{tabular}{|c||c|c|c|c|}
\hline $\begin{array}{c}\text { Enunc. Fundamental } \\
\text { Mediação }\end{array}$ & $\begin{array}{c}\text { Promessa } \\
\text { Interação }\end{array}$ & $\begin{array}{c}\text { Especif. Promessa } \\
\text { Global }\end{array}$ & $\begin{array}{c}\text { Território } \\
\text { Televisão }\end{array}$ & $\begin{array}{c}\text { Valores } \\
\text { Tecnologia/Pluralidade }\end{array}$ \\
\hline & $\begin{array}{l}\text { "A Globo pega pra valer" } \\
\text { expressa a capacidade da } \\
\text { emissora em captar a } \\
\text { audiência, conseguindo a } \\
\text { aderência do público }\end{array}$ & "Globo" = & "pega pra valer" = \\
nome da emissora & qualidade do sinal \\
\hline
\end{tabular}

\begin{tabular}{|c|c|c|c|c|}
\hline \multicolumn{5}{|c|}{ "A Globo 90 é nota 100" } \\
\hline $\begin{array}{c}\text { Enunc. Fundamental } \\
\text { Mediação }\end{array}$ & $\begin{array}{l}\text { Promessa } \\
\text { Interação }\end{array}$ & $\begin{array}{c}\text { Especif. Promessa } \\
\text { Global }\end{array}$ & $\begin{array}{l}\text { Território } \\
\text { Televisão }\end{array}$ & $\begin{array}{c}\text { Valores } \\
\text { Tecnologia/Pluralidade }\end{array}$ \\
\hline $\begin{array}{l}\text { “nota } 100 " \text { = } \\
\text { êxito da mediação } \\
\text { proposta }\end{array}$ & & & $\begin{array}{l}\text { "Globo" = } \\
\text { nome da emissora }\end{array}$ & \\
\hline
\end{tabular}




\begin{tabular}{|c|c|c|c|c|}
\hline \multicolumn{5}{|c|}{ "Globo e você, tudo a ver" / "toda hora tudo a ver" / "Mundo on-line" } \\
\hline $\begin{array}{l}\text { Enunc. Fundamental } \\
\text { Mediação }\end{array}$ & $\begin{array}{l}\text { Promessa } \\
\text { Interação }\end{array}$ & $\begin{array}{c}\text { Especif. Promessa } \\
\text { Global }\end{array}$ & $\begin{array}{l}\text { Território } \\
\text { Televisão }\end{array}$ & $\begin{array}{c}\text { Valores } \\
\text { Tecnologia/Pluralidade }\end{array}$ \\
\hline $\begin{array}{l}\text { "tudo a ver" = } \\
\text { mediação de todos os } \\
\text { tipos de 'objetos' } \\
\text { existentes }\end{array}$ & $\begin{array}{l}\text { "Globo e você" = parceria, } \\
\text { relação; } \\
\text { "tudo a ver" = } \\
\text { coisas em comum }\end{array}$ & $\begin{array}{l}\text { "tudo a ver" = } \\
\text { totalidade dos } \\
\text { conteúdos, sem } \\
\text { restrição de lugar } \\
\text { "mundo on-line" = } \\
\text { referência à internet }\end{array}$ & $\begin{array}{l}\text { "Globo" = } \\
\text { nome da emissora; } \\
\text { "ver" = } \\
\text { dispositivo televisual } \\
\text { "toda hora" = } \\
\text { pontualidade e } \\
\text { exaustividade da } \\
\text { grade televisiva }\end{array}$ & $\begin{array}{l}\text { "tudo a ver" = } \\
\text { pluralidade dos } \\
\text { conteúdos para uma } \\
\text { pluralidade de público }\end{array}$ \\
\hline
\end{tabular}

\begin{tabular}{|c|c|c|c|c|}
\hline \multicolumn{5}{|c|}{ "A Globo vira e mexe, mexe com você" } \\
\hline $\begin{array}{l}\text { Enunc. Fundamental } \\
\text { Mediação }\end{array}$ & $\begin{array}{l}\text { Promessa } \\
\text { Interação }\end{array}$ & $\begin{array}{c}\text { Especif. Promessa } \\
\text { Global }\end{array}$ & $\begin{array}{l}\text { Território } \\
\text { Televisão }\end{array}$ & $\begin{array}{c}\text { Valores } \\
\text { Tecnologia/Pluralidade }\end{array}$ \\
\hline & $\begin{array}{l}\text { "mexe com você" = } \\
\text { sensibilização do público }\end{array}$ & & $\begin{array}{l}\text { "Globo" = } \\
\text { nome da emissora }\end{array}$ & \\
\hline
\end{tabular}

\begin{tabular}{|c|c|c|c|c|}
\hline \multicolumn{5}{|c|}{ "Esse mundo é todo seu" } \\
\hline $\begin{array}{c}\text { Enunc. Fundamental } \\
\text { Mediação }\end{array}$ & $\begin{array}{l}\text { Promessa } \\
\text { Interação }\end{array}$ & $\begin{array}{c}\text { Especif. Promessa } \\
\text { Global }\end{array}$ & $\begin{array}{l}\text { Território } \\
\text { Televisão }\end{array}$ & $\begin{array}{c}\text { Valores } \\
\text { Tecnologia/Pluralidade }\end{array}$ \\
\hline $\begin{array}{l}\text { "mundo" = } \\
\text { referência ao mundo } \\
\text { natural mediatizado }\end{array}$ & $\begin{array}{l}\text { "todo seu" = } \\
\text { feito especialmente para o } \\
\text { telespectador. A interação } \\
\text { parte da emissora. }\end{array}$ & $\begin{array}{l}\text { "mundo" = } \\
\text { ampla cobertura }\end{array}$ & $\begin{array}{l}\text { "esse mundo" = } \\
\text { totalidade da } \\
\text { programação }\end{array}$ & $\begin{array}{l}\text { "esse mundo" = } \\
\text { um'mundo' de } \\
\text { conteúdos; } \\
\text { pluralidade de } \\
\text { conteúdos para } \\
\text { pluralidade de público }\end{array}$ \\
\hline
\end{tabular}

\begin{tabular}{|l|l|l|l|l|}
\hline \multicolumn{1}{|c|}{ "A Globo bola o que rola" } \\
\hline $\begin{array}{l}\text { Enunc. Fundamental } \\
\text { Mediação }\end{array}$ & $\begin{array}{c}\text { Promessa } \\
\text { Interação }\end{array}$ & $\begin{array}{c}\text { Especif. Promessa } \\
\text { Global }\end{array}$ & $\begin{array}{c}\text { Território } \\
\text { Televisão }\end{array}$ & $\begin{array}{c}\text { Valores } \\
\text { Tecnologia/Pluralidade }\end{array}$ \\
\hline $\begin{array}{l}\text { "bola o que rola" } \\
\text { criação de } \\
\text { tendências;influência } \\
\text { da mídia sobre a } \\
\text { sociedade }\end{array}$ & $\begin{array}{l}\text { "o que rola" = pressupõe a aspecto } \\
\text { aderência do público }\end{array}$ & $\begin{array}{l}\text { circular. Referência à } \\
\text { esfericidade do } \\
\text { planeta e ao âmbito } \\
\text { global de atuação }\end{array}$ & $\begin{array}{l}\text { "Globo" = } \\
\text { nome da emissora }\end{array}$ \\
\hline
\end{tabular}

\begin{tabular}{|c|c|c|c|c|}
\hline $\begin{array}{c}\text { Enunc. Fundamental } \\
\text { Mediação }\end{array}$ & $\begin{array}{c}\text { Promessa } \\
\text { Interação }\end{array}$ & $\begin{array}{c}\text { Especif. Promessa } \\
\text { Global }\end{array}$ & $\begin{array}{c}\text { Território } \\
\text { Televisão }\end{array}$ & $\begin{array}{c}\text { Valores } \\
\text { Tecnologia/Pluralidade }\end{array}$ \\
\hline & & $\begin{array}{l}\text { "tudo" = totalidade do } \\
\text { que acontece no } \\
\text { mundo, sem restrições }\end{array}$ & $\begin{array}{l}\text { "Globo" }= \\
\text { nome da emissora }\end{array}$ & $\begin{array}{l}\text { "tudo" = conteúdo } \\
\text { pluralizado para } \\
\text { público pluralizado }\end{array}$ \\
\hline
\end{tabular}

\section{"Um caso de amor com você" / "Um caso de amor com o Brasil"}

\begin{tabular}{|c|c|c|c|c|}
\hline $\begin{array}{c}\text { Enunc. Fundamental } \\
\text { Mediação }\end{array}$ & $\begin{array}{c}\text { Promessa } \\
\text { Interação }\end{array}$ & $\begin{array}{c}\text { Especif. Promessa } \\
\text { Global }\end{array}$ & $\begin{array}{c}\text { Território } \\
\text { Televisão }\end{array}$ & $\begin{array}{c}\text { Valores } \\
\text { Tecnologia/Pluralidade }\end{array}$ \\
\hline & $\begin{array}{l}\text { "caso de amor com você" } \\
\text { = envolvimento }\end{array}$ & & & \\
& & &
\end{tabular}




\section{"Uma nova emoção a cada dia"}

\begin{tabular}{|c|c|c|c|c|}
\hline $\begin{array}{l}\text { Enunc. Fundamental } \\
\text { Mediação }\end{array}$ & $\begin{array}{l}\text { Promessa } \\
\text { Interação }\end{array}$ & $\begin{array}{c}\text { Especif. Promessa } \\
\text { Global }\end{array}$ & $\begin{array}{l}\text { Território } \\
\text { Televisão }\end{array}$ & $\begin{array}{c}\text { Valores } \\
\text { Tecnologia/Pluralidade }\end{array}$ \\
\hline & $\begin{array}{l}\text { "emoção" = sensibilizar o } \\
\text { público }\end{array}$ & & $\begin{array}{l}\text { "a cada dia" = } \\
\text { referência à } \\
\text { programação } \\
\text { horizontal }\end{array}$ & $\begin{array}{l}\text { "nova emoção" = } \\
\text { tecnologia para } \\
\text { qualidade de imagem }\end{array}$ \\
\hline
\end{tabular}

\begin{tabular}{|c|c|c|c|c|}
\hline \multirow[t]{2}{*}{$\begin{array}{l}\text { Enunc. Fundamental } \\
\text { Mediação }\end{array}$} & $\begin{array}{l}\text { Promessa } \\
\text { Interação }\end{array}$ & $\begin{array}{c}\text { Especif. Promessa } \\
\text { Global }\end{array}$ & $\begin{array}{l}\text { Território } \\
\text { Televisão }\end{array}$ & $\begin{array}{c}\text { Valores } \\
\text { Tecnologia/Pluralidade }\end{array}$ \\
\hline & $\begin{array}{l}\text { "tá todo mundo de olho" = } \\
\text { pressupõe a participação } \\
\text { do público }\end{array}$ & & $\begin{array}{l}\text { "Globo" = } \\
\text { nome da emissora } \\
\text { "olho" = dispositivo } \\
\text { televisual }\end{array}$ & $\begin{array}{l}\text { "todo mundo" = } \\
\text { pluralidade do público }\end{array}$ \\
\hline
\end{tabular}

\begin{tabular}{|c|c|c|c|c|}
\hline \multicolumn{5}{|c|}{ "Globo 2000, no coração do Brasil" } \\
\hline $\begin{array}{c}\text { Enunc. Fundamental } \\
\text { Mediação }\end{array}$ & $\begin{array}{l}\text { Promessa } \\
\text { Interação }\end{array}$ & $\begin{array}{c}\text { Especif. Promessa } \\
\text { Global }\end{array}$ & $\begin{array}{l}\text { Território } \\
\text { Televisão }\end{array}$ & $\begin{array}{c}\text { Valores } \\
\text { Tecnologia/Pluralidade }\end{array}$ \\
\hline & $\begin{array}{l}\text { "no coração no Brasil" = } \\
\text { envolvimento entre } \\
\text { enunciador e enunciatário }\end{array}$ & & $\begin{array}{l}\text { "Globo" = } \\
\text { nome da emissora }\end{array}$ & $\begin{array}{l}\text { "Globo } 2000 "= \\
\text { expressão futurista } \\
\text { "Brasil" = todos os } \\
\text { brasileiros; pluralidade } \\
\text { do público }\end{array}$ \\
\hline
\end{tabular}

\begin{tabular}{|c|c|c|c|c|}
\hline \multicolumn{5}{|c|}{ "Emoção à vista" } \\
\hline $\begin{array}{c}\text { Enunc. Fundamental } \\
\text { Mediação }\end{array}$ & $\begin{array}{l}\text { Promessa } \\
\text { Interação }\end{array}$ & $\begin{array}{c}\text { Especif. Promessa } \\
\text { Global }\end{array}$ & $\begin{array}{l}\text { Território } \\
\text { Televisão }\end{array}$ & $\begin{array}{c}\text { Valores } \\
\text { Tecnologia/Pluralidade }\end{array}$ \\
\hline & $\begin{array}{l}\text { "emoção" = sensibilização } \\
\text { do público }\end{array}$ & & $\begin{array}{l}\text { "vista" = } \\
\text { dispositivo televisual }\end{array}$ & $\begin{array}{l}\text { "emoção à vista" = } \\
\text { tecnologia para } \\
\text { qualidade de imagem }\end{array}$ \\
\hline
\end{tabular}

\begin{tabular}{|l|l|l|l|l|}
\hline $\begin{array}{l}\text { Enunc. Fundamental } \\
\text { Mediação }\end{array}$ & \multicolumn{1}{|c|}{$\begin{array}{c}\text { Promessa } \\
\text { Interação }\end{array}$} & $\begin{array}{c}\text { Especif. Promessa } \\
\text { Global }\end{array}$ & $\begin{array}{c}\text { Território } \\
\text { Televisão }\end{array}$ & $\begin{array}{c}\text { Valores } \\
\text { Tecnologia/Pluralidade }\end{array}$ \\
\hline $\begin{array}{l}\text { "a gente" }= \\
\text { "a gente se vê" }= \\
\text { retratar a vida das } \\
\text { pessoas }\end{array}$ & $\begin{array}{l}\text { relação enunciador- } \\
\text { enunciatário } \\
\text { "a gente se vê" }= \\
\text { pressupõe participação do } \\
\text { público (produção e } \\
\text { recepção) }\end{array}$ & "vê" = & "a gente" = \\
dispositivo televisual & $\begin{array}{l}\text { toda as pessoas; } \\
\text { pluralidade do público }\end{array}$ & \\
\hline
\end{tabular}




\begin{tabular}{|c|c|c|c|c|}
\hline \multicolumn{5}{|c|}{ "Só se vê na Globo" } \\
\hline $\begin{array}{l}\text { Enunc. Fundamental } \\
\text { Mediação }\end{array}$ & $\begin{array}{l}\text { Promessa } \\
\text { Interação }\end{array}$ & $\begin{array}{c}\text { Especif. Promessa } \\
\text { Global }\end{array}$ & $\begin{array}{l}\text { Território } \\
\text { Televisão }\end{array}$ & $\begin{array}{c}\text { Valores } \\
\text { Tecnologia/Pluralidade }\end{array}$ \\
\hline $\begin{array}{l}\text { (a gente) "se vê" = } \\
\text { ver a si próprio através } \\
\text { dos meios; } \\
\text { "só se vê" = } \\
\text { exclusividade de } \\
\text { conteúdos. Mediação } \\
\text { diferenciada. }\end{array}$ & $\begin{array}{l}\text { "se vê" = } \\
\text { pressupõe a participação } \\
\text { do público (recepção) }\end{array}$ & & $\begin{array}{l}\text { "Globo" = } \\
\text { nome da emissora } \\
\text { "vê" = } \\
\text { dispositivo televisual }\end{array}$ & $\begin{array}{l}\text { (a gente) "se vê" = } \\
\text { pluralidade do } \\
\text { público; } \\
\text { "Só se vê (certos } \\
\text { conteúdos)" = } \\
\text { pressupõe saber-fazer } \\
\text { e poder-fazer que } \\
\text { garantem } \\
\text { exclusividade }\end{array}$ \\
\hline
\end{tabular}

\begin{tabular}{|c|c|c|c|c|}
\hline \multicolumn{5}{|c|}{ "A gente se liga em você" } \\
\hline $\begin{array}{l}\text { Enunc. Fundamental } \\
\text { Mediação }\end{array}$ & $\begin{array}{l}\text { Promessa } \\
\text { Interação }\end{array}$ & $\begin{array}{c}\text { Especif. Promessa } \\
\text { Global }\end{array}$ & $\begin{array}{l}\text { Território } \\
\text { Televisão }\end{array}$ & $\begin{array}{c}\text { Valores } \\
\text { Tecnologia/Pluralidade }\end{array}$ \\
\hline & $\begin{array}{l}\text { "a gente se liga em você" = } \\
\text { relação de } \\
\text { proximidade,envolvimento }\end{array}$ & & $\begin{array}{l}\text { "a gente" = emissora } \\
\text { "liga" = termo próprio } \\
\text { de aparelhos } \\
\text { eletrônicos }\end{array}$ & $\begin{array}{l}\text { "liga" = aparelhos } \\
\text { eletrônicos; } \\
\text { estado positivo, de } \\
\text { atividade } \\
\text { (ligado vs. desligado). }\end{array}$ \\
\hline
\end{tabular}

\begin{tabular}{|c|c|c|c|c|}
\hline $\begin{array}{l}\text { Enunc. Fundamental } \\
\text { Mediação }\end{array}$ & $\begin{array}{l}\text { Promessa } \\
\text { Interação }\end{array}$ & $\begin{array}{c}\text { Especif. Promessa } \\
\text { Global }\end{array}$ & $\begin{array}{l}\text { Território } \\
\text { Televisão }\end{array}$ & $\begin{array}{c}\text { Valores } \\
\text { Tecnologia/Pluralidade }\end{array}$ \\
\hline $\begin{array}{l}\text { "a vida, o mundo e } \\
\text { você" = situações, } \\
\text { objetos e pessoas do } \\
\text { mundo natural a } \\
\text { retratadas pela mídia }\end{array}$ & $\begin{array}{l}\text { "acompanhar (...) você" = } \\
\text { seguir de perto; estar } \\
\text { junto; } \\
\text { ser da mesma } \\
\text { mentalidade; } \\
\text { interagir em prol de } \\
\text { valores comuns }\end{array}$ & $\begin{array}{l}\text { "mundo"= } \\
\text { mudanças globais }\end{array}$ & "Globo" = emissora & $\begin{array}{l}\text { "a vida" = } \\
\text { todas as formas de } \\
\text { vida; pluralidade dos } \\
\text { comportamentos; } \\
\text { pluralidade do } \\
\text { público. }\end{array}$ \\
\hline
\end{tabular}

